Report No. 16

July 1993

Why the Gulf War Still Matters:

Foreign Perspectives on the War and the Future of International Security

Patrick J. Garrity
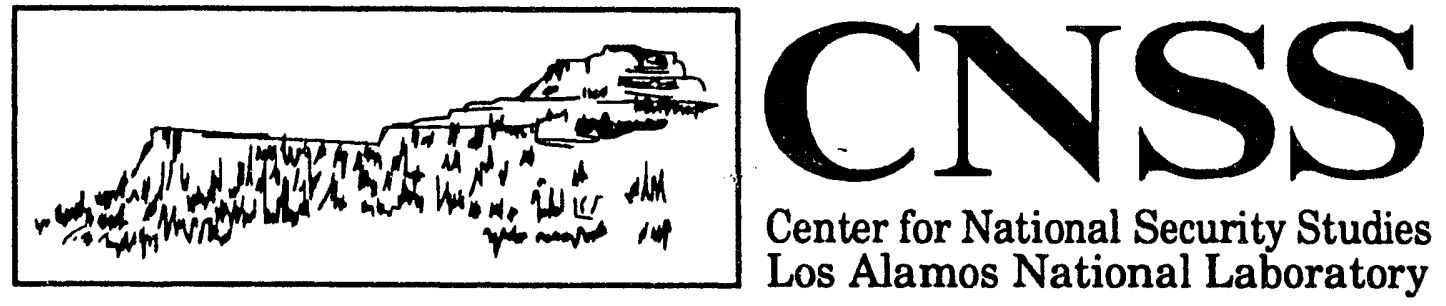

Center for National Security Studies
Los Alamos National Laboratory 


\section{CNSS REPORTS}

The following is a selection of the titles in the CNSS Report series.

No. 13. Criteria for Monitoring a Chemical Arms Treaty: Implications for the Verification Regime by Mark F. Mullen, Kenneth E. Apt, and William D. Stanbro (LA-12242), December 1991.

No. 14. Space Systems and the Military Geography of Future Regional Conflicts by Robert L. Butterworth (LA-12252), January 1992.

No. 15. The Strategic Arms Reduction Treaty and Its Verification by David B. Thomson (LA12364), July 1992. 
Report No. 16

July 1993

Why the Gulf War Still Matters:

Foreign Perspectives on the War and

the Future of International Security

\section{Patrick J. Garrity}

LA-12592

UC-900
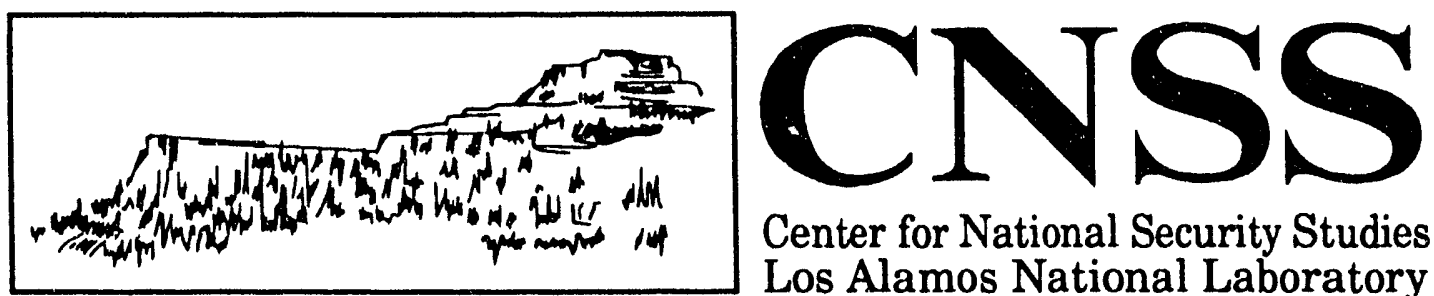

Center for National Security Studies Los Alamos National Laboratory

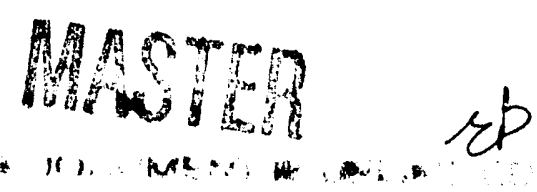


PATRICK J. GARRITY is a staff member with the Center for National Security Studies at the Los Alamos National Laboratory. He has been a research fellow at the Center for Strategic and International Studies, and has taught at the Catholic University of America and the Naval Postgraduate School. Dr. Garrity has published widely on U.S. nuclear-weapons policy, nuclear arms control, and international space policy. He is coeditor of Nuclear Weapons in the Changing World: Perspectives from Europe, Asia, and North America (Plenum, 1992).

\section{THE CENTER FOR NATIONAL SECURITY STUDIES}

The Center for National Security Studies conducts research and analysis, primarily on behalf of the Laboratory's management and programs, on policy issues and developments that may affect, or be affected by, the science and technology programs being pursued at the Laboratory. Specifically, CNSS strives (1) to identify new national priorities as they evolve, to understand their international and domestic settings, and to evaluate their effect on Laboratory programs; (2) to offer insights into the likely short-and long-term directions for Laboratory planning and operations, and to help identify scientific and technical contributions that Los Alamos could make to meet national needs; and (3) to assist directly in developing cr sustaining major Laboratory programs. In addition to this direct support to the Laboratory, the Center conducts a limited number of studies on behalf of Department of Energy agencies and other U.S. government departments.

The Center supports an interdisciplinary staff, drawing on expertise from the social sciences and the natural sciences. The Center has an active visitor and consultant program, as well as active postdoctoral, graduate research assistant, and service academy research associate programs to advance the careers of promising students of national security studies.

CNSS sponsors seminars and working groups to stimulate discussion of national and international security issues. These activities enhance communication between Los Alamos and other organizations that are studying issues of interest to the Laboratory.

The Center documents its work in a number of publications. The Briefings are short, informal papers commenting on timely topics that are appropriate to the Center's areas of interest. The Reports are formal research papers or edited conference proceedings. A book series, Issues in International Security, presents the results of the Center's research on key national and international security issues. 


\section{Acknowledgments}

This report is a synthesis of material provided by regional experts about lessons leamed from the Persian Gulf War by rations other than the United States. In preparing this synthesis, the Center for National Security Studies (CNSS) extends its thanks to Robert Swartz, CNSS Graduate Research Assistant (GRA), who was instrumental in assembling and analyzing the material for this report. James Thomas, also an assistant, provided detailed analyses of key Middle Eastem and Asian countries. David Lyons, a CNSS Undergraduate Student, put together a very useful compendium of lessons leamed by the United States. Robin Treasure, another undergraduate student, conducted considerable research into the European dimensions of the Gulf War. Gerrit Gong of the Center for Strategic and International Studies provided extremely insightful substantive and editorial advice at various points in the drafting process. As always, Arthur Nichols and Jan Dye of the CNSS staff did an outstanding job in editing and producing several drafts of this report.

In addition to the authors of various country studies (the list of reports follows these acknowledgments), CNSS would like to acknowledge a number of individuals who provided written or oral comments on various products associated with the project, or who attended CNSS meetings and workshops. (CNSS would also like to acknowledge the unclassified information provided by numerous U.S. government officials and active duty military officers, who are not identified here by name.) The experts cited in this study do not necessarily subscribe to the analyses and conclusions articulated in this report; those are the author's alone.

Political-Military Assessments. Stephen Biddle, Institute for Defense Analyses; Robert Butterworth, Aries Analytics; Eliot Cohen, Johns Hopkins University SAIS; Jeffrey Cooper, SRS Technologies; Steven David, Johns Hopkins University; Daniel Goure, Center for Strategic and Intemational Studies; Joseph Pilat, CNSS; Stephen Rosen, Harvard University; Don Snider, Center for Strategic and International Studies; and Richard Wagner, Kaman Sr, ,ences.

Western Europe. Ron Asmus, RAND; Charles Ball, CNSS; Patrick Glynn, American Enterprise Institute; Catherine Kelleher, Brookings Institution; Robbin Laird, Institute for Defense Analyses; Robert Pendley, CNSS; Dennis Rusinow, University of Pittsburgh; and Steven Szabo, Johns Hopkins University SAIS.

The Former Soviet Union and Eastern Europe. Nolra Trulock, CNSS; Jacob Kipp, Foreign Military Studies Office, Department of the Army; and Stephen Meyer, Massachusetts Institute of Technology.

Middle East/Persian Gulf. Lisa Anderson, Columbia University; Michael Dunn, the International Estimate; Michael Eisenstadt, Washington Institute for Near East Policy; Adam Garfinkle, Foreign Policy Research Institute; Ahmed Hashim, independent consultant; Robert Hunter, Center for Strategic and International Studies; Kenneth Pollack, Massachusetts Institute of Technology; and Ken Stammerman, CNSS.

Asia and the Pacific. Joseph Bermudez, Jr., independent consultant; Fred Brown, Johns Hopkins University SAIS; Michael Chinworth, the Analytic Sciences Corporation; Stephen Cohen, University of Illinois - Urbana/Champaign; Michael Green, Johns Hopkins University SAIS; Paul Godwin, National Defense University; Gerrit Gong, Center for Strategic and International Studies; Harry Harding, Brookings Institution; Thomas Mahnken, SRS Technologies; James Mihori, RAND; Katy Oh, RAND; Jonathan Pollack, RAND; Matthew Rubiner, MIT Japan Program; Gregg Rubinstein, the Nomos Corporation; Richard Samuels, Massachusetts Institute of Technology; Raju Thomas, Marquette University; and Robert Windrem, NBC News. 


\section{Reports Prepared for the CNSS Study of Lessons Learned from the Gulf War}

Cha, Young Koo. Korean Assessment of the Gulf War Lessons. September 1991.

Cheng, Dean. A Report on East Asian and Naval Lessons from the Gulf War. February 1993.

Chubin, Shahram. Iran and the Lessons of the Gulf War 1991. November 1991.

del Aguila, Juan M. Cuba's Views of the GulfWar and its Aftermath. Fcbruary 1992.

Earling, David. Italy and the Gulf War. September 1991.

Enders, Thomas, and Inacker, Michacl. The Second GulfWar and Germany: Contributions and Political and Military Lessons. October 1991.

Freedman, Lawrence. GulfWar Lessons Learned by Foreign Countries: Britain. October 1991.

Fontana, Andres. Gulf War Lessons Learned by Foreign Nations: The Argentine Case. December 19S11.

Garfinkle, Adam. Gulf War Lessons Learned by Foreign Nations: Jordan. July 1992.

Gashler, Karl S. China and the GulfWar: The Military-Technical Lessons. November 1992.

Goldberg, Jacob. Saudi Arabia and the Gulf Crisis. July 1991.

Gong, Gerrit, ed. Lessons Learned from the Persian Gulf War: Asian Perspectives. CNSS Briefing. August 1992.

Gow, James. Yugoslavia and Lessons from the Gulf War. October 1992.

Hossain, Ishtiaq. The Gulf War Lessons Learned by Foreign Nations: Vietnam and the ASEAN States. March 1992.

Joffe, Ellis. China after the Gulf War: Lessons Learned. November 1991.

Joffe, George. Libyan Reactions to the Conflict in the Gulf. July 1991.

Kam, Ephraim. Gulf War Lessons Learned by Egypt. March 1992.

Karsh, Efraim. Gulf War Lessons: The Case of Iraq. November 1991.

Karsh, Efraim. Gulf War Lessons: Syria. November 1991. 
Kinahan, Graham. India and Lessons from the Gulf War. August 1991.

Levran, Aharon. GulfWar Lessons - An Israeli Perspective. November 1991.

Liu Jinglian. Reflections on the Gulf War and Lessons Drawn from It. December 1991.

Mochizuki, Mike. Japan and the Persian Gulf Crisis: Lessons Learned. February 1992.

Pedhatzur, Reuven. Gulf War Lessons Learned By Israel. December 1991.

Proenca, Dominico, Jr. Brazilian Perceptions of the Persian Gulf War of 1991: An Impressionistic View. November 1991.

Swartz, Robert, ed. Lessons Learned from the Persian Gulf War: Middle East Perspectives. CNSS Briefing. July 1992.

Taylor, William J. and Mazarr, Michacl J. North Korea and the Gulf War: Pyongyang's "Lessons Learned." November 1991.

Thomas, James P. Indian Military Lessons from the Gulf War. August 1992.

Thomas, James P. Iranian Military Lessons Learned from the Gulf War. August 1992.

Villanueva, Luis. Spain: The Gulf War Lessons. November 1991.

Wu, Jaushieh Joseph. The Lessons of the Gulf War: The Perspective of the Republic of China. October 1991.

Xu Zhiming. China's View of the World Was Changed by the Gulf War. December 1992.

Yost, David S. France and the Persian Gulf War: Political-Military Lessons Learned. May 1992.

Yu, Peter Kien-hong, Yang, Richard H., and Yang, Andrew N. The 1990/91 Persian Gulf War Lessons: A Chinese View from Taiwan. October 1991. 


\section{Country Index}

Argentina: 9

ASEAN States (Singapore, indonesia, and Malaysia): 9-10, 21, 41, 43

Brazil: $8,51,89$

Britain: $55,65,68-69,73,113$

China $(P R C)$ : xii, xviii, $\mathrm{xx}, 3,7,10,12-13,16,44,53,56,61,65,67-68,75,77-80,113$

Cuba: xii, 7, 11, 16, 30-31, 51, 56, 89-90

East Asia (general): xiii, 5, 8, 21, 111

Eastern Europe (Poland and the Czech Republic): 89

Egypt: xviii, 6-9, 14, 22, 62, 64, 75, 83-84

Europe (general): xii-xiii, 10, 13, 23-25, 111

France: $x v i i, 11-12,22,24,53-54,58-59,69-73,113$

Germany: xii-xiii, xvii, xx, 3, 13, 24-26, 29, 53, 55, 63, 69, 73-75, 111, 113

India: xiv, 7, 10-11, 32, 43, 53, 56, 58, 63, 66, 68, 76-77

Iran: xii-xiv, xviii, 3, 7, 11, 16, 30-32, 37-41, 50-51, 65-67, 75, 97-100, 113

Iraq: xii-xiv, xviii, 11, 14-16, 22, 30-35, 56-58, 92-94, 113

Israel: xvi-xviii, $12,52,54-55,61-62,64-65,68,75,80-83$

Italy: xvii, 24, 52-54, 56, 65, 67-70

Japan: xiii, xvii, xx, 3, 8, 16, 25-30, 69-70, 111, 113

Jordan: 14,43

Libya: xiv, 7, 11, 30-32

Middle East (general): xiii, 5, 8, 14-16, 21, 111

North Korea: xiv, xviii, 7, 11, 30-33, 67, 94-97

Saudi Arabia: xiv-xv, 9, 14, 41, 43

South Korea: xviii, 8-9, 16-17, 53, 75, 84-86

Soviet Union/Russia: xvi, xx, 1, 3, 7, 10-11, 53, 55, 59-60, 62-65, 90-92, 113

Spain: xvii, 24-25, 65, 67, 69-70

Syria: xiv, 9, 31-32

Taiwan (ROC): $41,43,50,67$

Turkey: 24,68

Vietnam: 22, 51, 65

Yugoslavia, former states of: xiv, 13-14, 31, 35-37, 41-43, 51, 54, 62-64, 67, 88 


\section{Executive Summary}

This report summarizes the main findings of a Center for National Security Studies (CNSS) project that examined how a number of nations other than the United States have reacted to the course and outcome of the Persian Gulf War of 1991. The project was built around studies of key countries on which the Gulf War might reasonably be expected to have had a significant impact: Argentina, the ASEAN states, Brazil, China, Cuba, Egypt, France, Germany, India, Iran, Iraq, Israel, Italy, Japan, Jordan, Libya, North Korca, Russia, Saudi Arabia, South Korea, Spain, Syria, Taiwan, the United Kingdom, Victnam, and the states of the former Yugoslavia. These country studies were written by well-recognized independent experts following a common set of guidelines provided by CNSS. When the country studies were completed, they were reviewed and supplemented through a series of peer assessments and workshops. The report represents a synthesis of material generated through this process, and is intended to stimulate thought and further analysis on the critical topics discussed herein.

The United States Matters. The indivioual country studies of foreign perspectives on the Gulf War reached a virtually unanimus conclusion: the American performance in Operation Desert Shield/Desert Storm indicated that the United States is the "only superpower." (Perhaps more accurately, most foreign observers were persuaded that the United States is the only nation now capable of exercising leadership on a global or regional basis, although its power is by no means unconstrained.) In the summer of 1990 , by contrast, there had been serious questions about whether American power and the "American system" of strategic relationships built up during the Cold War would retain their relevance given the disappearance of the Soviet threat, the rise of the new economic superpowers in Germany and Japan, and the general diffusion of power in the international system. The Gulf War represented a potential watershed in foreign perceptions of the United States. As of March 1991, the continued relevance-even dominance-of American power, and of Washington's willingness to exercise that power, was unquestioned.

This judgment about American power was generally not limited to the military realm; the United States was seen as much more than just the sole military superpower. To be sure, military power was a critical element in defining American superpower status But foreign observers were also impressed by the ability of Washington to manage the Gulf War crisis and conflict by reaching and maintaining an effective domestic consensus. The United States also demonstrated the ability, willingness, and internationally recognized legitimacy to exercise global political leadership. Finally, perhaps the most important and unique U.S. attribute in the Gulf crisis and war was its 
ability to act as an integrator of nations and policies. This was seen in contrast to the domestic and international weaknesses of Germany and Japan-the two powers most widely secn as emerging contenders for global status in a world in which economic strengths were supposed to be more important than military capabilities as a source of international influcnce.

In fact, for many nations in the immediate aftermath of Desert Storm, there was considerable concern about the possible emergence of an American-dominated "unipolar world." American policy during the Gulf crisis and war suggested that the United States, freed from the constraints of the Cold War and encouraged by its overwhelming triumph in the Gulf, might enter into a new phase of international activism. This activism would be marked by Washington's efforts, using the political-military capabilities and strategy that it exhibited during the Gulf War, to impose its notions of democracy, human rights, and economic development on states with different values.

During and after the Gulf War, most nations adjusted their policies to anticipate the perceived rise in the value of American power and the possible emergence of American policies designed to enforce a unipolar world. This involved bandwagoning with, balancing against, or seeking autonomy from, the United States, as each nation judged appropriate given its regional circumstances and its assessment of the purpose and duration of American power. Ironically, some states which aligned themselves more clearly with the United States during and immediately after the war are now expressing reservations about Washington's policies. At the same time, a few other key states which sought to increase their autonomy from Washington in the wake of the Gulf War experience have quictly begun to trim back their more ambitious plans and are exploring possibilities of improved cooperation with the United States.

Although emphasizing the strengths that the United States displayed during the war, foreign observers also noted American weaknesses, particularly economic. A few states, especially those with antagonistic relations with the United States, magnified these problems to the point of anticipating Washington's decline. From this perspective, the Gulf War represented the last hurrah of fading power. Deeply rooted trends in international relations towards multipolarity-trends that were evident long before the Gulf War-will reassert themsclves once the political afterglow of the U.S. performance in Operation Desert Storm wears off. Declinist views tend to be asserted by those states which feared a near-term U.S. drive to enforce idcological hegemony in the wake of the Gulf War (c.g., Iraq, Iran, Cuba, and to some extent China). The U.S. decline is not expected to manifest itself fully for another five to ten years, so it has limited operational value for the day-to-day policy making of these states.

There has been some rethinking and downgrading of American power in the aftermath of the Gulf War by foreign observers, but the United States is still regarded as the sole superpower. That said, there is a considerable international divergence conceming the character and duration of U.S. superpower status in light of Washington's post-Cold War interests and intentions. The most important change has been increasing international uncertainty about U.S. goals and policies, fueled in large part by American policy toward the former Yugoslavia and postwar Iraq. Some key European states, most notably Germany, are becoming increasingly concerned about long-term 
U.S. commitment to their region. These Europeans believe that domestic concerns are taking precedence in American policies, despite the Clinton administration's insistence that the United States is not disengaging from European affairs. Concerns about a U.S. withdrawal are also increasing in East Asia, where the Japanese informally profess to see limits on American capabilitics as well as willingness to maintain its regional sccurity commitments. These European and Asian vicws are potentially a marked departure from those held immediately after the Gulf War. Even in the Middle East, at least prior to the U.S. cruise missile strike against Bagdad in June 1993, many elites were beginning to suspect that any Amcrican global retrenchment would affect U.S. commitments in their region as well.

The uncertainty about American interests and intentions has obviously increased in light of the change in presidential administration. The Clinton administration may be quickly tested politically, if not militarily, as other states determine whether the principal lesson of the Gulf War-the United States chose to matter-is still the case.

Military Power Matters. The Gulf War demonstrated that military power matters becausc (1) regional inter- and intrastate conflicts are likely to occur in the future international environment; (2) such conflicts matter to powers outside the region; and (3) external military power, probably organized under international auspices, can at least in some circumstances be threatened or used to affect the course or decide the outcome of regional conflicts. Various states, or parties or groups within states, are responding to this implication of the Gulf War in different ways according to their particular national or factional perspectives.

The majority of states, especially the major powers, are secking the means to influence or control the process of international (or American) decision making that will lead up to the possible use of force in regional interstate and intrastate conflicts. Perhaps most importantly, the Gulf War demonstrated to Germany and Japan that they could not translate their economic strength into greater international power and influence if they remained "introverted" states. Monetary contributions to future international crisis management or military enforcement actions will not be sufficient. The Germans and Japanese are accordingly secking ways to contribute to intemational peace and security besides providing money-while gaining corresponding influence over the process by which decisions about peace and security are made. The precise long-term direction of German and Japanese policies is far from settled; there are still major disagreements among parties and factions. The Gulf War revealed a fundamental lack of national consensus about post-Cold War interests and security policies in both Germany and Japan. As noted above, the governing parties in these countries are trying to become more actively involved in political-strategic affairs, including taking tentative steps to develop new tools of intervention. But there is considerable opposition in Germany and Japan to these policies of "pushing out the security envelope" into nontraditional military or quasi-military roles. Even the political opposition favors greater activism and a more outward-looking orientation, but the differences regarding appropriate means and outlook remain significant and the long-term trajectory of Japanese and German security policy therefore remains highly uncertain. 
Some states or factions - those that see themselves as potential targets of intemational military action, such as Serbia, Iraq, and Iran-are seeking the means todissuade or deter such intervention. The general approach of such states is to rely on political measures desighed to reassure external powers (or at least to obfuscate the situation), coupled with measured increases in select military capabilities to raise the price of intervention. The war, combined with the loss of the Sovict counterweight, nevertheless had a clear "chilling effect" on states potentially hostile to American and Westem interests. This has led to or reinforced a rulc of thumb: do not take actions that will provoke international responses, especially those that would serve as a cover for U.S. military action. There is a problem with following such a rule: these states and factions are currently uncertain about the precise threshold for triggering intemational military action. For the moment, they are tending to err on the side of caution while probing to determine where "red lines" exist. (The decision of the United States and the international community not to intervene militarily in the Bosnian conflict may suggest to such states that the threshold for intervention may be higher than previously supposed.) There is no indication that the Gulf War caused any state or faction to alter fundamentally its ambitions over the longer term - but they are seeking (or continuing to seck) more subtle and long-term means of achieving them. These means include political "charm offensives" that break down the willingness of at least some key external powers to intervene.

Some key states within this category - Iraq, Iran, North Korea, Libya, and Syria-have placed increased priority on weapons of mass destruction and ballistic missiles after the Gulf War. The remark of a retired Indian Army Chief of Staff on the lesson of the Gulf-“"Don't fight the Americans without nuclear wcapons"- has been widely cited as indicative of the thinking of Third World states on this issue. A more representative formulation might be stated as follows: If a state has nuclear weapons, it may not need to fight the Americans. Nevertheless, calculating the costs and benefits of trying to obtain nuclear weapons is a complex exercise even for the most antiWestern states. There are a number of reasons to acquire weapons of mass destruction besides.their effect on the United States and other extemal powers, such as regional prestige. For these states, intemational organizations and agreements (e.g., the United Nations and the nonproliferation treaty) are run by and for the great powers. Ambitious "have not" countries must get around these agreements in order to buy themselves a place at the table of the great powers, and nuclear weapons, especially in light of the Gulf War, are seen as an important way to do this. But such programs are two-edged swords: nuclear weapons might conceivably deter international intervention, but efforts to develop them might also serve as a lightning rod for extemal military action designed to preempt such programs, or as an excuse for outside intervention in local or regional conflicts.

Finally, other states or factions-those that see themselves as potential victims of local or regional aggression - are seeking the means to encourage intemational intervention on theirbehalf. The Gulf War was a graphic demonstration to "weaker" states and factions of their vulnerability in the post-Cold War era. The Iraqi invasion of Kuwait, which (in Saudi eyes) nearly became an assault on Saudi Arabia, dispelled the notion that security could be maintained largely through nonmilitary instruments and by local means. A few states, such as Saudi Arabia, believe that their intrinsic importance is such that they can rely on the military guarantec of the only superpower, 
the United States-although the Saudis still want the American presence to stay over the horizon. Most other states with the potential to become "victims" do not think that they can rely on Washington alone. They therefore tend to favor strengthening UN security mechanisms that deal with the maintenance of international peace and security. There is little confidence that such mechanisms can be relied upon, however, absent an ability to force the aggressor to conduct reasonably costly and sustained operations, thereby perhaps drawing in the intemational community, on humanitarian grounds if nothing else.

Technology Matters. Operation Desert Storm demonstrated to foreign observers the advent of a new type of modem warfare characterized by the integrated employment of advanced military technologies, well-led and well-trained forces, and superior doctrine and operational concepts. Many, but not all, foreign experts are of the view that the Gulf War was the first significant display of a variety of technologies that have the potential to dominate warfare over the next several decades. As a consequence of this assessment, the Gulf War has received a good deal of attention from foreign militaries, even if they believe that the circumstances of the war were unique or not directly applicable to their own immediate security problems. This demonstration forced a general reevaluation of national military capability and competence.

The general reaction among foreign militarics to the coalition's performance in the Gulf War ranged from "surprised" to "stunned." The surprise was not that the coalition won, but that the war ended so quickly and with so few casualties for the coalition forces. Forcign militaries were also not surprised that technology played a major role - but as a rulc they did not expect that advanced technologies would prove to be so effective and that they would play such a dominant role. Most foreign military assessments did note the exceptional circumstances of the Gulf War that favored the coalition. Most foreign assessments tended not to dwell on the limitations on American military power that these circumstances might have implied, but rather on the inherent potential, capabilities, and advantages possessed by advanced military forces.

Foreign observers tended to focus on three capabilities that set the United States apart as a giobal military superpower and underpinned its ability to wage a unique form of high-technology, highintensity warfare. These are logistics, information management, and combined arms/joint operations. The particular technological strengths of the United States were seen as being in air power, precision-guided munitions, space systems, battlefield surveillance, electronic warfare, night fighting, and the imaginative use of helicopters. Identified weaknesses in the coalition's performance were in the areas of locating and destroying Iraqi mobile missiles; overcouning Iraqi cover, concealment, and deception (CCD) practices; operating fixed-wing aircraft is bad weather; conducting amphibious operations against Iraqi sea mines and coastal defenses; and coordinating and utilizing intelligence (both strategic and tactical). Upon reflection, early favorable impressions of the Patriot' s antitactical ballistic missile (ATBM) capabilities have been downgraded by foreign observers.

Many experts in the United States proclaimed that the Gulf War marked a revolution in military affairs, alluding to the forecasts of an emerging "military-technical revolution" that had been advanced by the Soviet General Staff beginning in the late 1970s and early 1980 s. There is, in fact, 
a widespread sense that the Gulf War did signal a technology-driven change in the character of warfare. At the same time, there is a strong sense among most foreign militaries that, even if such a military-technical revolution has occurred theoretically, it has limited practical significance for them given fiscal and/or societal realities.

The most radical interpretation of the meaning of the Gulf War comcs from some elements on the Russian General Staff (this interpretation is by no means dominant in Russia, however). From this perspective, future war will be dominated by attacks on systems rather than attacks on forces. In this kind of war, aerospace operations become the primary means to accomplish strategic objectives. These objectives - control or denial of territory - can be fulfilled without physically occupying that territory. In such a war, linear formations and stable fronts are obsolete. Tankheavy, mass formations are irrelcvant; surprise, strategic initiative, preemption, and space systems are critical. A rnore typical vicw is expressed by the Israeli military, which believes that the Gulf War pointed more towards an ongoing evolution in warfare, whereby there will be a blend of old and new technologies. Tanks have not become obsolete, although they may serve different functions in the future. Air power will be an essential element in future combat operations, but it cannot itself be decisive, and it cannot occupy territory.

Foreign military experts believe that the Gulf War provided evidence for the following specific trends in military affairs.

- Air power. The war clearly marked a new or renewed appreciation for air power, particularly its utility in the early and perhaps decisive stages of a war. Most foreign militaries are not operating on the assumption that air power will itself be decisive, however. Under the right circumstances, air power might defeat invading forces, but it cannot occupy territory or force a change of regime.

- The offense-defense relationship. Most forcign military observers now stress the advantages that advanced technologies will provide the offense over the defense. Static, barrier-type defenses were seen as being particularly ineffective under conditions of modern warfare.

- Surprise attack/preemption. Owing in part to the advantages of the offense over the defense, there is a widespread belief that the new technologies may increase the probability of a successful surprise attack.

- The relationship between firepower and maneuver. The Gulf War marked the continuation of a significant rise in the value of firepower due to the expanded employment of precise and smart munitions. Liddell Hart's indirect approach of defeating an enemy without having directly to engage his main forces can now (in theory) be implemented with firepower rather than maneuver.

- The uncertain economics of high technology. From one perspective, the cost-effectiveness equation works decidedly in favor of pushing for quality over quantity; high-tech weapons systems and munitions can serve as force multipliers, ease logistic burdens, and compensate for military deficiencies. But advanced weapons technologies may be vulnerable to relatively cheap countermeasures, such as cover, concealment, and deception. As a rule, smaller powers 
cannot afford to get caught up in a measure-countermeasure game that involves increasingly costly high-tech weapons.

- Bailistic and cruise missiles. Surface-to-surface missiles (SSMs), and possibly cruise missiles, look increasingly attractive in regional military contexts. They are also one of the few areas in which second- and third-tier states can compete with the major powers. Mobility for SSMs seems to provide excellent prospects for survivability against counter-air operations.

- Weapons of mass destruction, especially nuclear weapons. There is a real divergence between the major powers' view of the declining utility of nuclear weapons, and the views of some second- and third-tier states, which see the value increasing. The value in this context, as noted previously, is much more political than military-it is aimed at deterring the major powers from intervening in a conflict, rather than providing an instrument of direct military utility.

- Professionalism. The Gulf War strongly pointed to the advantages of smaller, more professional military forces. In nations where there has been an ongoing battle between "professional" and "political/revolutionary" approaches to military affairs, the Gulf War strongly reinforced the position of the former (without completely eliminating the influence of the latter).

- Space systems. The Gulf War underscored the great and perhaps decisive potential of space systems. The cost of these systems, however, may incline most foreign militaries to purchase space-based capabilities from third parties, or to devise less expensive means (e.g., airbreathing systems) of achieving the same ends.

Several key points should be made in summarizing how these insights from the Gulf War will affect the specific plans of foreign militaries. First, for most foreign militaries, the Gulf Wartended to reinforce and accelcrate existing trends and policies, rather than set them off in completely new directions. Second, no nation is seeking to compete with the United States by acquiring military capabilities of equivalent magnitude across the full range of new technologies. Third, most foreign militaries are thinking about selectively incorporating technologies that were demonstrated during Operation Desert Storm, in the context of their own national security objectives and military circumstances. The focus is on new technologies that promise to be more effective in achieving existing political-military goals, rather than striving for revolutionary effects on the battlefield.

The general reaction of the major democratic industrial powers to the Gulf War-Japan, Germany, France, and to a lesser extent Italy and Spain-was the importance of achieving minimum autonomous national (or regional) capabilities in certain key military-technical arcas, such as survivable command, control, communications, and intelligence $\left(\mathrm{C}^{3} \mathrm{I}\right)$; strategic reconnaissance and early waming (satellites and radar); precision-guided munitions; logistics; and tactical ballistic missile defenses. These states are not planning to acquire capabilities equal to those of the United States in magnitude or overall effectiveness, but they are interested in exploiting the relevant technologies to meet their minimum standards and specific national (or alliance) requirements. The problem that the other western industrial powers face in seeking limited 
autonomy is expense. Serious investments in the areas listed above would strain or exceed the national defense budgets of these nations, which are expected to decline over the next decade. As a result, they will clearly be interested in creative, innovative solutions to address these perceived requirements. At the same time, the Westem industrial states now assume that any significant military deployment will be within the context of a multinational force; their need for limited autonomous capabilities will be judged in this context.

Leading regional powers (e.g., China, Egypt, Israel, and South Korea) have a perspective quite different from that of the democratic industrial states on the meaning of the Gulf War for their own military forces. Most regional powers now have an increased appreciation of the value of air power and air defense. Also, the war pointed to a few narrow technical areas on which these powers are now tending to concentrate. The most prominent among these are electronic warfare/electronic countermeasures, night combat capabilities, and precision-guided munitions. Other areas of interest include cheap means of surveillance (e.g., remotely piloted vehicles, or RPVs), $\mathrm{C}^{3} \mathrm{I}$, and advanced SSMs. Regional powers are thus tending to concentrate their resources in a few critical areas, rather than revamping their military capabilities across the board, primarily because of the expense that the latter approach would entail. Regional powers are tending to move away from large standing armies towards smaller, more professional, and better trained forces. In some cases, there may be an interest in moving toward two-tiered forces: a small, high-quality, high-tech firsttier force, and a larger, mass-oriented second tier.

Surprisingly, military lessons leamed seem not to have been the focus of powers actually or potentially hostile to the West (e.g., Iran, North Korea, even Iraq) as they reacted to Operation Desert Storm. To the extent that Gulf War lessons learned are being applied at the military level, they are fundamentally conditioned by concerns other than those of fighting the United States. For most of the hostile powers, the dominant considerations are often as much internal control and prestige as traditional combat effectiveness. Military effectiveness itself is measured against potential regional adversaries much more than against the United States. That said, such powers understand that circumstances beyond their control could bring about conflict with the United States and/or an international coalition. The limited evidence available suggests that under these circumstances, the smaller powers would be inclined to adopt asymmetrical counters to the American style of warfare, and that the Gulf War represents a model (albeit imperfect) of how to prosecute that war.

The essential goal of an asymmetrical strategy would be regime survival, not military victory over the United States or an international coalition. A hostile power's asymmetrical strategy would thus depend first and foremost on avoiding the decapitation of the political and military leadership by that air campaign, especially at the outset of a conflict. Second, a hostile state would try to prevent or dissuade the United States from "taking Baghdad" on the ground in later stages of the war. The hostile state may be unable to do this by military means, as Iraq could not; it must therefore provide the United States with incentives not to occupy the entire country. (Secretary of State James Baker's threat to Tariq Aziz in January 1991 suggested an important American threshold 
that might trigger an escalation of U.S. war aims - the use of weapons of mass destruction.) Third, an asymmetrical campaign by a hostile power would seek to seize or regain the initiative by striking at U.S. and coalition centers of political gravity. These centers of gravity are, first and foremost, the American political systcm and American public opinion, which are sensitive to casualties, the length of the conflict, and collateral damage. The American-led coalition will have the same sorts of sensitivities, and there will be inherent differences of policy and interest among coalition members. Finally, coalition members will be concerned with any threats to their homelands that the hostile power might be able to pose.

In short, foreign specialists tend to regard Saddam's basic approach to the Gulf War as sound, even if his strategy was flawed and poorly executed. The challenge to future hostile powers that might find themselves at war with an American-led international coalition is to devise better means to impose costs (casualties, time, and collateral damage) on the coalition-without triggering escalation in the coalition's war aims or in the intensity of its military operations. There is a strong sense that hostile states confronting the United States in the future will try to optimize the lowtechnology end of the spectrum. Cover, concealment, and deception will likely rank high as elements of any aggressor's strategy against advanced military powers. Cheap countermeasures are another potential means of dclaying or disrupting operations by an advanced military power. More ambitiously, hostile states might look to imaginative combinations of dual-use and proliferated technologies, possibly combined with new operational concepts. Because civilian deaths and damage in the CNN era can be so politically troublesome, a hostile powermight actually seek to "encourage" collateral damage and to facilitate Western media coverage of that damage. Terrorism remains a potential tool to take the war to the enemy, as does ecological and economic warfare (as Saddam attempted by pumping oil into the Persian Gulf and igniting Kuwaiti oil wells).

Does the Gulf War Still Matter? Foreign assessments of the Gulf War have changed over time, and continue to do so. In some sense, the Gulf War may represent more of an aberration than a model for future international bchavior, especially as compared with arguably more typical developments, such as the crises in the former Yugoslavia and in Somalia. Nevertheless, the report concludes that the Gulf War still does matter to other nations. The Gulf War remains the first important test of political-military capabilities in the post-Cold War era; foreign nations judge trends-up or down-from this basic reference point. In addition, the Gulf War revealed, or confirmed, certain fundamental facts about international relations that remain pertinent even though foreign powers acknowledge the uniqueness of Operation Desert Shicld/Storm.

What do these facts imply for Amcrican policy makers? The following "so whats" emerged form the study.

- Since the end of the Gulf War, scrious intemational concems have begun to reemerge about the short-term willingness, and long-term capacity, of the United States to serve as the organizing force in international relations generally, and in most regional contexts as well. If Washington wishes to play this role in the future, it must demonstrate to foreign observers that U.S. power will continuc to be applied purposefully and effectively to achieve American and 
international objectives. This is an ongoing requirement-the success of Operation Desert Storm has a finite half-life; foreign leaders will forever be asking the question, "what have you done for me lately?" At the same time, if the Unitcd States wishes to retain its intemational preeminence (a status that a sizeable majority of nations would prefer it to retain, although they do not wish American power to be completely unbalanced), the United States must visibly address three long-term sources of its power: its economic and technological competitiveness; its global military effectiveness; and its international legitimacy.

- The United States will play a crucial role in shaping expectations about the future international system and the kind of security arrangements that will be appropriate to that system. In the short term, American actions towards Somalia, the former Yugoslavia, and other hot-spots are establishing a pattern of international peacemaking and peacekeeping (or lack thereof) that began with the Gulf War. Over the longer term, the structure of the international system will depend on how the United States accommodates other centers of power that were marginalized in the Gulf crisis but that will inevitably seek, in one form or another, their places in the sun (e.g., Germany, Japan, Russia if it remains intact, and China). The objective here will be to see that these major centers will define themselves as satisfied partners in, rather than opponents of, an international system crafted largely by American initiative.

- The United States will play an especially crucial role in managing the accommodation of two key centers of power, Germany and Japan. Given the domestic and intemational resistance to the assumption of great powerstatus by Berlin and Tokyo, the process of change toward a more "normal" foreign policy - a process begun by the Gulf War-may be lengthy and uneven. Still, events may force a more rapid decision than we now expect (e.g., the emergence of a nuclcar-armed North Korea, the spread of national and ethnic violence toeast-central Europe). In any case, the United States should anticipate that Germany and Japan will become more activist and shouldencourage and support that activism where appropriate, even if Washington is slightly ahead of international and domestic opinion on this subject (as the Bush administration was on the question of German unification).

- The United States faces an acute near-term problem in defining credible mechanisms for maintaining regional security. The Gulf War model suggested that the United States would take the lead in regional security, at least in the Middle East, but subsequent American policy, especially in Europe, pointed toward a division of labor that would place the immediate burden of regional security on local powers, with Washington serving as a reinforcer and global guarantor of stability. The latter model seems to be unsatisfactory and unworkable to regional powers, and there is concern that recent American policy points toward a disengagement of the United States from key regions, especially Europe and East Asia. The United States may not be able to finesse this issue much longer: it must either devise a satisfactory division of labor and responsibility for all concerned, or follow the path of disengagement.

- The United Nations is not likely to provide a comprehensive solution to the dilemma of regional security, despite the promising beginning of the Gulf War. The great powers seem more likely 
than not to become deadlocked on questions involving regional security, and the issue of German and Japanese membership will continuc to be a complicating factor. This is not to say that the United States should abandon the U.N. as a useful instrument of national policy and international security, to be employed wherever possible. Rather, American policy makers should be realistic about probable constraints on the United Nations, and avoid creating expectations that U.N. approval is necessary for action in any and all circumstances.

- The United States should recognize that many non-Western states were frightened by the implications of the Gulf War, that is, of a militarily dominant West enforcing its will on what it regards as lesser powers. This perception could lead to the formation of national or cultural coalitions designed to counter what might be regarded as a wave of Western neo-imperialism. The need to dissuade the formation of such a coalition, by positive or negative means, must become an important consideration in policies designed to deal with seemingly discrete issues, · such as the crises in the former Yugoslavia, which raised questions in the Islamic world about Western intentions and priorities. 


\section{Contents}

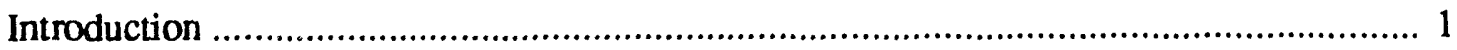

Chapter One: The United States Matters ................................................................. 5

Foreign Perspectives on the United States .................................................... 6

Changing National Policies and Interests in the Aftermath of the Gulf War ........... 8

Perceptions of U.S. Power: Enduring and Transitory ...................................... 12

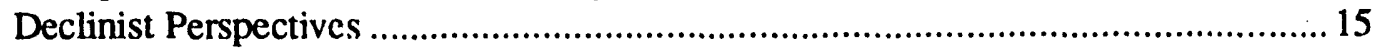

The Bottom Line: The United States Still Matters ............................................... 17

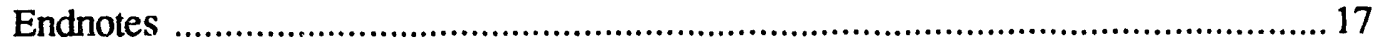

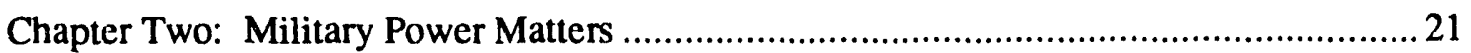

Case Study: The Westem European Response ................................................ 23

The Response of Major Military-Technical Powers: Germany and Japan .............. 25

The Response of "Aggressor" States or Factions ................................................ 30

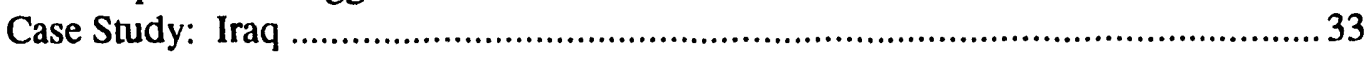

Serbia: A Case Study of Dissuading/Deterring Military Intervention ..................... 35

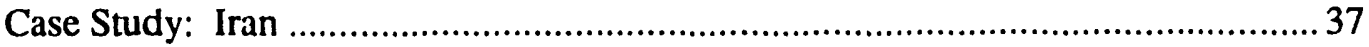

The Response of Potential "Victim" States or Factions ....................................... 41

Conclusion: Military Power Still Matters ........................................................ 43

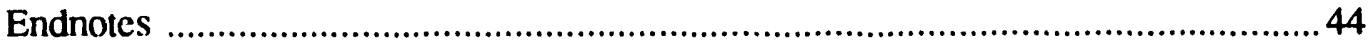

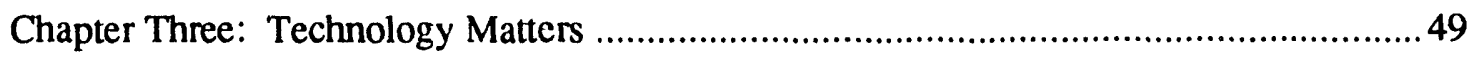

Highlights of Foreign Military Reactions to the Gulf War ..................................5 50

Military-Technical Evaluation of the Coalition's Performance ...............................50

Weaknesses in the Coalition's Performance .....................................................5. 54

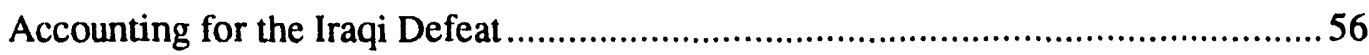

Accounting for the Iraqi Defcat: An "Iraqi" Perspective ....................................55

Operation Desert Storm and the Changing Character of Warfare ...........................55

Soviet/Russian Views of Future War ...........................................................5

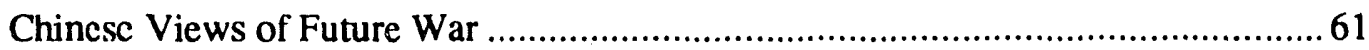

Israeli Vicws on the Future Character of Warfare .............................................61 61

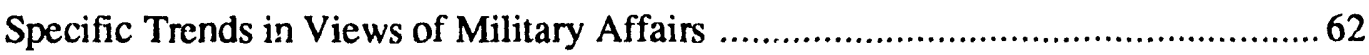

The Gulf War and National Military-Technical Adaptation .................................68

Military-Technical Adaptation by the Democratic Industrial Powers .....................69

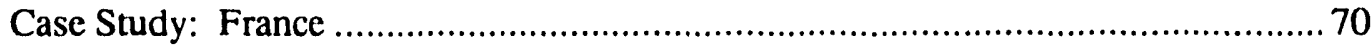

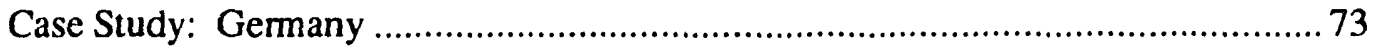

Military-Technical Adaptation by Important Regional Powers .......................... 75

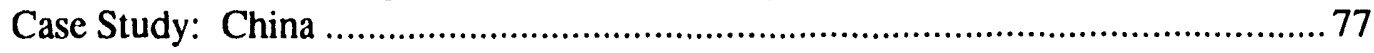

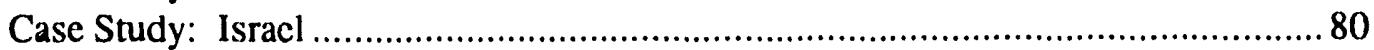

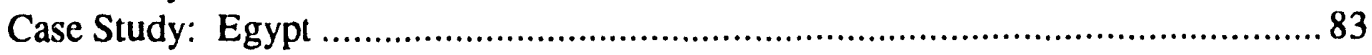




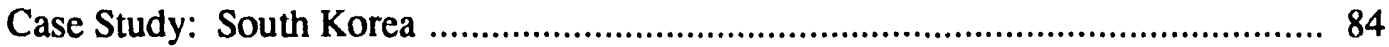

Military-Technical Adaptation by Potentially Hostilc Powers ............................. 86

Case Study of Adaptation by a Former Adversary: Russia ................................ 90

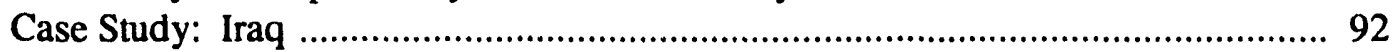

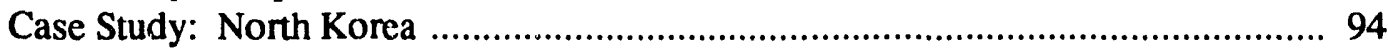

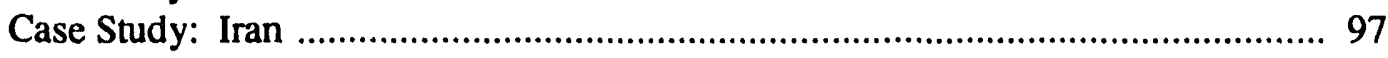

The Bottom Line: Technology Matters …....................................................... 100

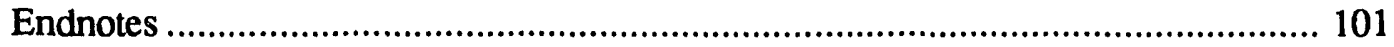

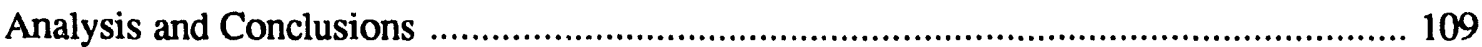

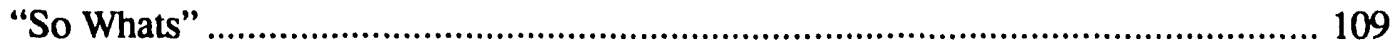

Was the Gulf War a Watershed? ................................................................ 114

Appendix. Study Outline: Gulf War Lessons Learned by Foreign Nations .................... 117 


\title{
Why the Gulf War Still Matters: Foreign Perspectives on the War and the Future of International Security
}

\author{
Patrick J. Garrity
}

\section{Introduction}

This report summarizes the main findings of a Center for National Security Studies (CNSS) project that examined how a number of different nations besides the United States have reacted to the course and outcomc of the Persian Gulf War. The Center undertook this project as part of its charter to assist Los Alamos National Laboratory management and scientific staff in their decision making about technical priorities and Laboratory directions. The project was initiated in the summer of 1991 and continued through the winter of 1992-93. Information contained in this report should be up-to-date through June 1993, although it is difficult to eliminate all anachronisms, given rapidly moving international developments.

The report does not pretend to be the final word on the subject of foreign reactions to the Gulf War. It represents a synthesis of material provided by numerous expert contributors and commentators, and is intended to stimulate thought and further analysis on the critical topics discussed herein. The experts cited in this study do not necessarily subscribe to the analyses and conclusions articulated in this report; those are the author's alone.

Purpose of the Study. In early 1991, the Gulf crisis and war seemed to mark a defining moment in what was becoming the post-Cold War era. Numerous official and unofficial studies were initiated in the United States to sort out what lessons could be drawn from Operation Desert Shield/Storm. These lessons learncd, in turn, have understandably become ammunition in the ongoing political debate about future American foreign policy and military strategy. In a few cases, American analysts also attempted to account for the reaction of other countries to the Gulf War. This was notably true with respect to the former Soviet Union, and especially the lessons learned by the Soviet/ Russian military. However, to the best of our knowledge, there has been noother broad-based and systematic attempt to review the impact of the Gulf War on key major powers and regional states. It seems to us that such review is essential to developing a balanced and comprehensive picture of the long-term implications of the Gulf War. Given the Center's responsibilities to the Laboratory, we are naturally most interested in the military lessons that other nations may have taken away from the war, and the sorts of technological problems/opportunities that these foreign lessons may create for the United States in the future. But we cast the study more broadly, to use the Gulf War as a prism-admittedly, one of many-to assess fundamental trends in the post-Cold War international system, to see others as they see themselves (and see us).

The project has consumed more time than we originally intended. In some cases, the delay can 
be accounted for by the difficulty of identifying and working with experts in as diverse, and as many, countries as we attempted to study. But for the most part, the delay was indicated by the fact that foreign assessments of the Gulf War have changed, and continue to do so. These views are being altered in large part because of the rapidly evolving international context, including the ongoing crisis with Iraq and the emerging crises in areas such as Yugoslavia and Somalia. The electoral defeat of President George Bush in November 1992 also changes the context in which many states will view the Gulf War.

All this brings to mind the supposed remark of a Chinese leader when asked about the significance of the French Revolution: "It is too soon to tell." We have made the judgment that, although the significance of the Gulf War may appear different one or five years or fifty years from now, enough time has now passed so that the immediate after-glow of Operation Desent Storm has dissipated, and more enduring foreign judgments can now be registered.

The passage of time has raised another issue in the minds of some who reviewed this study: does the Gulf War still matter? That is to say, does the Gulf War in retrospect represent more of an aberration than a means for understanding the future? Have other nations not devalued the apparent early lessons of the war in light of other, arguably more typical developments, such as Yugoslavia?

Our answer is, on the whole, no: the Gulf War still matters. Much has obviously changed since February-March 1991. The Gulf War, contrary to speculation at the time, did not lead to the creation of a New World Order. But the Gulf War remains the first real data point in the postCold Warera; foreignnations still judge trendsup or down-from this basic reference point. In addition, the Gulf War revealed, or confirmed, certain fundamental facts about international relations that will hold even though foreign powers acknowledge the uniqueness of Operation Desert Shield/Storm. The war, and its aftermath, also pointed toward a large measure of uncertainty about the future. Other nations are coming to grips with these uncertainties, and will continue to do so for some time, with the Gulf War still an important guide in this process.

Methodology. The project was built around studies of key countries for which the Gulf War might reasonably be expected to have had a significant impact: Argentina, the ASEAN states, Brazil, China, Cuba, Egypt, France, Germany, India, Iran, Iraq, Israel, the United Kingdom, Italy, Japan, Jordan, Libya, North Korea, Russia, Saudi Arabia, South Korea, Spain, Syria, Taiwan, Vietnam, and the states of the former Yugoslavia. These country studies were written by well-recognized independent experts (see p. vii), following a common set of guidclines provided by CNSS (see Appendix). Each author was asked to provide an assessment of the reaction of controlling opinion in his or her country of study, in the following areas:

- an objective analysis of the course and outcome of the Persian Gulf War

- political-military lessons learned from the war, and how these might affect future national goals and policies

- military-technical lessons lcarned from the war, and how these might affect future military doctrine, force structure, and operations

- assessment of the U.S. strengths, weaknesses, and objectives in the wake of the Gulf War.

Each study was to identify not only the controlling national opinion in these areas, but also significant debates and important minority views. The authors used open sources from their respective countries to gather data: interviews with government officials and private individuals; newspapers, magazines, radio, and television; specialized joumals, especially military; and publications and conferences from research institutions.

When the country studies were completed, they were reviewed and supplemented through a series of peer assessments and workshops. One workshop was held for each of the three major regions (Europe, East Asia, and the Middle East). A preliminary draft of this report was also circulated to the original study authors and 
other experts, including those in the U.S. government and military, for comment. At least 250 country and functional experts were consulted on the project's findings through this review process.

Caveats. It is important to emphasize the limits that any such summary report contains. First, as with any summary, it necessarily relies greatly on generalizations as well as on specific national case studies. Generalizations often lack nuance, and nuances can be critical in understanding the real versus the apparent impact of the Gulf War. One nuance, as we have already noted, involves whether particular reactions by foreign govermments to the war are transitory or enduring.

Second, any study such as this must be careful not to attribute every significant change in international politics to the event bcing examined (i.e., the Gulf War). Obviously, many other events of significance have occurred during the past several years, and some of these have had a greater impact on particular nations than did the Gulf War. The overarching event of significance, obviously, is the end of the Cold War and disintegration of the Soviet Union. Other key defining events will vary from nation to nation. For Germany, the great political detcrminant was (and remains) the experience of unification. For China and its relations with the extemal world, Tiananmen Square has been the watchword. For Iran, the first Gulf War (the one with Iraq, between 1980-88), was the most important single event of the past decade, not the second between Iraq and the American-led coalition.

It is often difficult to disaggregate the impact of the Gulf war from these other key developments, especially from the end of the Cold War. We have attempted not to over-emphasize the importance of the war, but rather to put any lessons leamed in the larger context of the rapidly changing international environment. Still, for clarity of presentation, this report does not always attempt to distinguish whether the Gulf War experience was a primary or a secondary determinant for political and military decision makers.

Third, nations may not draw unitary lessons about the Gulf War-the Russian General Staff has a much different perspective on this subject than does President Boris Yeltsin and his advisers; the Japanese Liberal Democratic Party has leamed very different lessons from those held by the Japanese Socialist Party, and neither of these corresponds to the views of nationalist elements in Japan. For the purposes of argument and presentation, the report will often refer to "Germans" or "North Koreans," but the reader should be aware that unfortunately these terms of convention can sometimes be as much misleading as revealing. We do attempt wherever possible to recognize the distinctions among various important national figures or factions when they are visible and important to our analysis.

Fourth, we must recognize that some naiions may be careful to conceal-or at least not publicize-lessons that they may have drawn from the Persian Gulf crisis and war. At an extreme, they may go as far as attempting to deceive the United States or other nations about how the war might have affected their policies-especially with respect to military-technical lessons. We can hardly expect that a state seeking to find political, operational, or technological counters to the military capabilities displayed by the United States in Operation Storm would be anxious to share this information. There has been little evidence of this tendency to date, but the possibility is certainly worthy of note.

Finally, the most important factor in determining Gulf War lessons learned by many foreign states will be their perception of U.S. lessons learned. This is especially true at the military-technical level, where many nations simply lack the ability to understand what the United States did during the Gulf War. For them, they will rely heavily on following the internal U.S. discussion and debate over American strengths and weaknesses, what the Iraqis did well and did poorly, how various coalition partners performed, and so on. More broadly, foreign nations will look to the U.S. lessonslearncd process for clues about the future direction of American foreign and military policy. In shon, we ourselves have shaped, and will continue to shape, by design or accident, much of 
the world's perception of the Gulf War. This fact presents both dangers and opportunities for American policy makers.

Organization of the Report. The report is organized into three chapters, corresponding to the main conclusions reached by the study. Chapter One analyzes the point that, in the eyes of most foreign observers, the Gulf War demonstrated that the United States matters, that is, the United States is the only global superpower willing and able to exert political, economic, and military power in every region. The chapter explores the concern of many states, especially immediately after the Gulf War, about the possible emergence of an American dominated "unipolar world." It also assesses how various nations are responding to American power and leadership in the post-Cold War world-by bandwagoning, balancing, seeking autonomy, or some combination of the three. The chapter concludes with a review about how foreign assessments about American power have changed overtime since the end of the Gulf War.

Chapter Two assesses foreign perspectives on why and how military power matters in light of the Gulf War experience. The chapter discusses the importance that is now being placed on international military intervention in regional conflicts. It then considers the means by which various classes of states might seek to influence, deter, or encourage military intervention. The classes of states are (1) the industrial democracies, especially Germany and Japan; (2) potential "aggressor" states or factions, such as Iran and Serbia; and (3) potential "victim" states or factions, such as Saudi Arabia or Bosnia.

Chapter Three examines the changing character of warfare as revcaled by Operation Desert Shield/Storm, especially the fact that technology matters on the current and future battlefield. The chapter provides highlights of foreign military-technical assessments of Operation Desert Storm; evaluates foreign views of the meaning of the Gulf War for the future character of warfare, including whether the Gulf signaled a revolution in military affairs; and considers how a selection of foreign militaries-major states, second-tier states, and potentially hostile powers-are (or are not) adjusting their military doctrine, force structure, and investment strategy to account for the lessons of the Gulf War.

The report concludes with an analysis of the issues forfuture U.S. foreign and military policy that may emerge as a consequence of foreign reactions to the Gulf War. 


\section{Chapter One: The United States Matters}

The individual country studies of foreign perspectives on the Gulf War reached a virtually unanimous conclusion: the American performance in Operation Desert Shield/Desert Storm indicated that the United States is the "only superpower." The exact definition-and duration-of that superpower status remains contentious, however.

In a certain sense, this conclusion is not surprising. With the "time of troubles" in the Soviet Union in 1990 and 1991, followed by the collapse of the USSR, one of the two Cold War superpowers had essentially disappeared, quite independently of events in the Gulf. Nevertheless, in the summer of 1990 , there were serious questions about whether American power and the "American system" of strategic relationships built up during the Cold War would retain their relevance given the disappearance of the Soviet threat, the rise of the new economic superpowers in Germany and Japan, and the general diffusion of power in the international system. For some, notably in East Asia, the decline of the United States had pointed to the emergence of a multipolar world. For others, notably in the Middle East, the questions about the relevance of the United States had less to do with American power than with American intentions and will to defend U.S. interests.

The Gulf War represented a potential watershed in foreign perceptions of the United States. As of March 1991, the continued relevanceeven dominance - of American power, and of Washington's willingness to exercise that power, was unquestioned. Operation Desert Storm demonstrated to most foreign observers that the United States was no longer constrained by the
East-West competition-and that the United States would henceforth not be tied down geographically by the need to maintain large forces in Europe to defend against the USSR. This widespread foreign assessment of a dominant U.S. position led nations to align themselves more closely with, balance against, or find autonomous means of influencing the United States, depending on their regional circumstances and ambitions.

The international perception of dominant American power signaled by the Gulf War has persisted to the preseni, much more so than perhaps American policy makers realize. However, foreign observers are increasingly uncerLain as to how the United States plans to use (or not use) its strong position; some questions about American power are again beginning to emerge. The Clinton administration will be closely watched for signs of its intentions, and its early actions in crises such as Yugoslavia, the former Soviet Union, Iraq, and Somalia are decisively influencing the trajectory of foreign assessments of the United States that initially emerged from the Gulf War experience.

One additional point should be noted: there is a sense among a number of foreign governments and analysts that the United States erred in stopping the war when it did. If the coalition had fought for another day or two, so the argument goes, it would have destroyed more of the Republican Guard force that is essential to keep Saddam Hussein in power. ${ }^{1}$ The United States, by this logic, would not necessarily have had to march on to Baghdad to bring about a change in regime. Because Saddam 's rule continues, however, and because Iraq remains a festering issue 
in, if not an immediate threat to, Persian Gulf security, the ultimate success of Operation Desert Storm has become increasingly open to question.

\section{Foreign Perspectives on the United States}

The Gulf Warindicated to foreign powers that the United States did indeed still matter, despite the end of the Cold War, and that America would be the dominant global power for at least the remainder of the decade. The judgment that "the United States is the only superpower" was made by virtually every country study. This judgment was not limited to the military realm; the United States was seen as being more than just the sole military superpower. Francois Heisbourg summed up well the emerging international view of the United States in the immediate aftermath of the Gulf War: “... the United States is by far the greatest power, the sole power with a truly global capacity to defend its interests, with the will and the means to take the diplomatic and military initiative in the face of great challenges to the functioning of the international syste'n."

To be su.e, American military power is a critical element in defining its superpower status. Other nations had known that a gap existed between them and the United States, or between them and the advanced industrial states, in hightechnology, high-intensity warfare, but the magnitude of that gap came as a major surprise for most foreign militaries. The war specifically highlighied certain overwhelming and unique American capabilities that defined it as the only global military power: (1) logistics-the ability to move large forces over long distances, and sustain those forces for a significant period of time; (2) information management-the collection, integration, and distribution of strategic, operational, and tactical intelligence, the ability to communicate from and to all levels, and the ability todeny information and communications to an adversary; and (3) the capacity to wage joint operations and a combined ann: cam- paign. The decisive American edge in combat thus came not just from advanced technology, but from the ability to imbed this technology in a style of warfare that cannot be matched by any other power.

But foreign observers were also impressed by the ability of Washington to manage the Gulf War crisis and conflict. Americans may have seemed divided to themselves, but other countries noted a domestic structure and political consensus that allowed the United States to take and implement decisions relating to peace and war. This was seen internationally in contrast to the domestic weaknesses of Germany and Japan, the two powers most widely seen as emerging contenders for global status in a new, economically dominant world.

Third, the United States demonstraied the ability, willingness, and intemationally recognized legitimacy to exercise global political leadership. All nations did not necessarily embrace American ideology-a particular type of capitalism and democracy - but the vast majority of the intemational community was willing to follow, or at leastnotoppose, Washington's lead. It is perhaps most accurate to say that the Gulf War revealed noother contender for global leadership and that the U.S. style of leadership under President Bush was regarded as congenial to most states.

Finaliy,perhaps the mostimportant and unique U.S. attribute in the Gulf crisis and war was its ability to act as an integrator of nations and policies. As Shahram Chubin characterized the common foreign perspective of the United States:

The 'super-power' of the U.S. clearly stemmed not simply from its size or its superior resources, but from its ability to harness its power and concentrate it effectively ... Above all it came from an ability to mount an integrated effort across a broad spectrum of capabilities and to marshal the resources-social and political-as well as economic and military in anintegrated manner. $^{3}$

An assessment of Egypt's response to the Gulf War is also fairly typical of foreign lessons learned: 
For the Egyptians, the Gulf war highlighted once again the enormous strategic strength of the United States; the more so since the war took place on the background of the collapse of the Sovict Union and the Communist bloc, and the formation of the new world order. The Egyptians indicate the combination of the military-technological strength, the economic wealth and the political-diplomatic capability-which was reflected in the American administration's success in convincing the main body of Western countries and the Arab world to contribute forces and assistance to such a coalition; such a combination provides the United States with unprecedented strength in modern times. ${ }^{4}$

By contrast, the Gulf War revealed that Germany (orEuropc) and Japan, despite their growing economic capabilities, still lacked the full range of power resources to match or compete with the United States. This important weakness-a lack of "systems integration" skillwas demonstrated again for Europe in the Yugoslav crises that occurred after the Gulf War. This political-military gap between the United States and the rest of the world is still tending to encourage great and small powers to strergthen their relations with the United States, even if they seek autonomy in certain key areas, as discussed below.

Foreign observers did appreciate certain U.S. weaknesses and constraints on American action-mostnotably in the economic realm, where the image of the Uncle Sam going hat-in-hand for financial contributions for Operation Desert Shield/Storm did make a serious, and negative, impression. The Egyptian assessment cited above also noted that the Unitcd States would have "problems pertaining to the limits of its power to achieve its objectives, especially in the Middle East, and to fulfil the expectations created by its victory in the war." nesses and problems tended to be washed out in the afterglow of the war, however.

In fact, for many nations in the immediate aftermath of Desert Storm, there was considerable concem about the possible emergence of an
American-dominated "unipolar world."6 Even before the Gulf War, some nations such as India (and Iraq) had observed that the United States now would have much more disposable military power following the effective collapse of the Soviet Union as a superpower. American policy during the Gulf crisis and war suggested that Washington might indeed use its military power - that the United States, freed of the constraints of the Cold War and in the wake of its overwhclming triumph in the Gulf, might enter into a new phase of international activism. This activism wouldbe marked by Washington's efforts, using the political-military capabilities and strategy that it exhibited during the Gulf War, to impose its notions of democracy, human rights, and economic development on states with different values. For some, the American effort in the Gulf was intended to reinforce this point as well as to defeat the Iraqis. The Cuban Communist Party held that "U.S. ruling circles took full advantage of the situation and realized a spectacular demonstration of force and technological supremacy in military hardware, clearly aiming to frighten the world." 7 The Libyan government concluded that Operation Desert Storm "was designed to terrify and intimidate other would-be aggressors and proliferators of unconventional weapons."

Fears of U.S. unipolarity were particularly pronounced in states that were avowedly or potentially hostile to the United States, such as Iran, North Korea, Cuba, and China; by conservative forces in the then-Sovict Union; and by much of the Palestinian community. The impression of a unipolar world was particularly strong for regional powers that had once been aligned with the former Soviet Union. The Cuban Communist Party declared at its Fourth Congress in October 1991 that changes in the last few years have produced a "unipolar world, characterized above all by the military hegemony of American imperialism ... The Gulf War contributed decisively to this military and political consolidation." ${ }^{\text {" Unipolarity manifests }}$ itself for Cuba in the form of a coalition of advanced, capitalist states led militarily by the United States, even if this "grand coalition" is 
divided on specific national, regional, bilateral, or multilateral issues.

Much, although by no means all, of the Palestinian community believe that, with the fall of the USSR, the United States seeks to be the world hegemon and is ready to exploit all of the world for its materialist greed. It is particularly said to be the enemy of "spiritual" Islam. The Arabs, in turn, have never been weaker. The solution: refuse capitulation, prepare for a "people's war" under the banner of Islam or Arabdom, with the ultimate barrier to U.S. aims being the depth of faith and community. ${ }^{10}$ To be sure, the Palestinian community remains divided and has noimmediate means to pursue this policy against the United States.

Concern about excessive U.S. activism was especially strong in East Asia, including among U.S. allies. Ironically, nations in this region had originally tended to be influenced by the "U.S. is in decline" perspective prior to the Gulf War. Even for American allies like Japan and South Korea, the concern after Operation Desert Storm was that Washington's more aggressive posture would create instabilitics and lead to conflicts (e.g., with North Korea) as the United States sought to enforce a New World Order.

The concern about unipolarity was also evidenced even in nations such as Brazil, where elites speculated that Washington might seek to organize Gulf War-stylc coalitions against states that were perceived to violate international norms. The common view in Brazil was that future American policy in this unipolar world might prove to be old wine in new bottles. Washington might we"l retain its "militaryindustrial logic" and continue to arm rather than disarm. Some in Brazil hold that Germany and Japan will eventually (rc)emerge as the "natural enemies" of the United States now that the Soviet Union has collapsed. Perhaps a more widespread perspectivc is that the United States, unopposed by other grcat powers, will seek to shape other nations in its own image and values. Chief among the American objectives would be the "solution" of global issues such as the international drug trade, the proliferation of advanced military technologies, and environmental issues. (These so-called global issues are, in fact, seen as a cover for broader U.S. interests and goals.) For many Brazilian elites, the interests of their country could well be threatened by American action in these areas (e.g., de-forestation), and they are thus suspicious of a possible emerging pattern of U.S.-led intervention in regions such as the Persian Gulf. ${ }^{1 "}$

This intemational concem about unipolarity should not be overplayed, but it is important to emphasize that the Gulf War left an immediate and decided impression of Amcrican power and geopolitical and ideological activism. U.S. rhetoric about a New World Order tended to be taken more seriously in foreign countries than it was here. There was a period of waiting after Operation Desert Storm, much of it anxious, to see exactly what the New World Order might mean in practice.

\section{Changing National Policies and Interests in the Aftermath of the Gulf War}

During and after the Gulf War, most nations adjusted their policies to anticipate the perceived rise in the value of American power. This involved bandwagoning, balancing, or seeking autonomy (or some combination thereof) as each nation believed appropriate given their regional circumstances and assessment of the purpose and duration of American power. Ironically, some of those states which aligned themselves more clearly with the United States during and immediately after the war are now expressing reservations about Washington's policies. At the same time, a few other key states which sought to increase their autonomy from Washington in the wake of the Gulf War experience have quietly begun to trim back their more ambitious plans.

Bandwagoning. For some governments, the perception of a dominant U.S international position led to overt steps towards an accommodation with the United States, or to make an existing pro-American alignment clearer. This was especially true in the Middle East. For example, Egypt was confirmed in its long- 
standing judgment that the United States was the dominant global and regional power. Egypt was impressed with the fact that

the United States was willing to use massive military force in order to prevent the undermining of the balance of power in a distant part of the world. The more so since the American military intervention completely suited the Egyptian regional interests as well; in fact during the crisis Egypt helped to convince the American administration to keep a hard line toward Iraq. ${ }^{12}$

Instcad of building up its independent deterrent force or pursuing the Damascus Declaration idea of using Egyptian and Syrian forces in the Gulf, Saudi Arabia is aligned more prominently with the United States and regards Washington as the principal guarantor of security in the region.

These alignments have not been made without important reservations that may havc important implications. The Egyptians are somewhat nervous about American policies in the region because Saddam remains in power. Cairo is also disappointed with the fact that the Saudis have opted for an over-the-horizon U.S. umbrella rather than the use of Egyptian forces for Gulf security, and suspect that Washington encouraged this. The Mubarak govemment also resents the fact that the United States has not supported Egypt's proposals for limiting the proliferation of weapons of mass destruction in the Middle East. The Saudis themselves remain reserved about the U.S. role, as witnessed by their refusal, at least covertly, to reach a formal security agreement with the United Statesalthough close cooperation obviously continucs.

The Syrians also used the Gulf crisis as an opportunity to improve their ties with the United States, implementing a policy decision that had actually been made prior to the war in light of the growing weakness of Damascus' superpower patron, the USSR. Syria has once again begun to show a certain toughness towards the United States and the peace talks, which is probably dircctly related to its perception that the U.S. rolc in the Gulf may be transicnt and that
Washington is now looking inward. However, Syria is not likely to return to a confrontational stance because it has no superpower patron and is too close to Israel to risk the consequences if war should occur.

For a nation like Argentina, whose govemment for a variety of reasons had decided to move closer to the United States, the Gulf War likewise provided such an opportunity. (Ironically, Brazil, which has traditionally had far friendlier relations with the Colossus of the North than Argentina, was generally opposed to American policy in the Gulf crisis.) As a study of Argentine reactions to the Gulf War noted:

The Gulf experience has contributed to consolidate that pro-American policy, based on a close relationship with the U.S.... The Gulf War helped to create consensus in some sectors of society, the political leadership, and the armed forces with regard to the current foreign policy, based on the alliance with the U.S. and the personal friendship and commitments of Presidents Menem and Bush. This means a significant departure from the Argentine traditionin foreign policy, which was characterized by a permanentusually dissimulated-hostility or, at least competition. $^{13}$

A number of states in Asia and the Pacific also availed themselves of the opportunity todemonstrate their ties to the United States. South Korea supported U.S. war efforts in order to consolidate its security relations with the United States and to demonstrate Westem unity to the North. (Seoul's assistance, however, was more modest than some had proposed, in part because of concem that a disproportionate South Korean share of the war costs might create a precedent for greater burdensharing. ${ }^{14}$ ) The Kuwait crisis reinforced for Singapore the importance of having a close and identifiable relationship with a superpower. Singaporeans have the perception that Saddam Hussein would have been much less likely to invaded Kuwait if the rulers of that country had not been ambivalent about their relationship with the Americans before the invasion. In this regard, Kuwait's decision after the war to sign a ten-year mutual 
defense treaty with the United States-a treaty that allows the Americans to use Kuwaiti military installations - was regarded by Singapore as a correct policy decision. It also confirmed to the Singaporeans the wisdom of allowing U.S. naval forces to use their port facilities as a partial replacement for those in the Philippines. In fact, Singapore officials have noted that the Kuwaiti-American defense arrangement was modeled on this Singapore-U.S. memorandum of understanding. ${ }^{15}$

For domestic and intemational reasons, not all states wish to have a close and identifiabic relationship with the United States. Nevertheless, the Gulf War increased the perceived acceptability and valuc of a continued American regional military presence for nations such as Indonesia and Malaysia (even if they continue to oppose the existence of permanent American bases in the region). ${ }^{16}$ India's initial opposition to U.S. policy against Iraq has mellowed somewhat over time, to the point where New Delhi now seeks to accommodatc Washington as the remaining superpower. This is primarily for economic reasons (India is dependent on the United States and Japan for International Monetary Fund loans), but also to avoid political and military confrontations with the United States in the future. Prior to the Gulf War, the conventional wisdom in India was that the United States was in decline; the war changed this view and persuaded India that the United States would remain a superpower formuch longer than it had carlier expected, especially militarily. ${ }^{17}$ After 1991, the Soviet card disappeared for India and not long afterward the American card disappeared for Pakistan, making possible a new alignment. ${ }^{18}$

For the West Europeans in general, the Gulf War revalidated the importance of the American security commitment. The war demonstrated that Europe, collectively or as individual national entities, could yet not deal with major problems that might be expected to emerge in the "arc of crises" to the east and south. The Gulf War, along with other contemporaneous events (especially the tum to the right in the then-Soviet Union), arguably saved, at least for the moment, the principal instrument of Ameri- can power and influence on the continent-i.e., NATO.

Balancing. But for other nations and other actors, the Gulf War pointed toward the necessity to find the means to balance an unexpectedly powerful United States. Conservative elements in the Soviet Union (and subsequently Russia) clearly felt resentment at the treatment that this former superpower has received at the hands of Washington. This resentment included American policy toward Moscow in the Gulf War and the virtual destruction of a former Soviet client state. Such resentment on the Russian right has been reflected in calls to oppose Westem intervention against Serbia in the ongoing Balkan crises.

Some politically influential observers in Europe [e.g., former French Foreign Minister Roland Dumas and European Community (EC) Commissioner Jacques Delors] have argued that, in view of the USSR's disintegration and the strength shown by the United States in the Gulf War, the power and influence of the United States should be balanced and limited by a stronger and more cohesive EC and by greater use of the Security Council. ${ }^{19}$ In fact, the Gulf War saw a greatly increased interest in the United Nations and other international institutions-not only for their own sake, but as a potential means for restraining U.S. unilateralism.

The major power most inclined to balance against the United States in the aftermath of the Gulf War was China. For the PRC, the Gulf War suggested that Washington might become far more aggressive and militant in its relations with Beijing, which called into question the Chinese damage-limitation strategy towards the United States in the aftermath of Tiananmen Square. The Chinese therefore debated the possibility of returning to a Third World-oriented strategy designed to build up an antiAmerican bloc. This remains an option, although not an ideal one, for Beijing if relations with Washington should deteriorate in the coming ycars.

India, as noted above, has moved somewhat in the direction of accommodating the United States in the wake of the Gulf War; however, India 
would prefer to see the emergence of a rival superpower, most likely Russia, and would support such a development. Along these lines, New Delhi was very receptive to a recent initiative by Russian President Boris Yeltsin, who called for the emergence of an Asian counterweight to gain political levcrage in dealings with the United States and the West. Russia, China, and India were said to be obvious members of such an Asian coalition..$^{20}$ New Delhi also sees the possibility of an economic rivalry emerging, involving the United States, the European Community (Germany), Japan, and possibly China (in the next century). But India foresees no countervailing military power to the United States. ${ }^{21}$

There were also a number of lesser powers that believed themselves to be out-of-step with the American New World Order. The Gulf War demonstrated graphically that they could no longer rely on the implicit or explicit support of the former Soviet Union, or use the Soviet card in some fashion to limit the range of U.S. action against them. These states included Iraq, North Korca, Iran, Cuba, and Libya. Such states do not at the moment have a realistic means to balance the United States directly (although some hope a revived Russia or a united Europe might provide such a balancc over time). North Korea, among others, looks to Third World counter-alliances (e.g., with Iran and Syria) to check American power. ${ }^{22}$

Likewise, from Fidel Castro's perspective, in a multipolar context brought about by the eventual decline of the United States, the alliance of China and Third World countries might at some point in the future act as a countervailing force to the United States. In the meantime, to combat thc "galloping hegemonism" of the United States, particularly in the Third World, Cuba argues that small countries therefore must unite and, if possible, form blocs that would add to their strength. The Cuban government specifically expresses its fraternal unity with China, Vietnam, and North Korea. It also calls on the NonAligned Nations movement to "overcome its wcaknesses" and resume its role in world politics. $^{23}$
Small powers like Cuba, which are unprepared or unable to bandwagon with the United States, are thus seeking to find ways to continue to pursue their aspirations without provoking American-led intervention. These strategies are described in the following chapter on the importance of military power.

Autonomy. The most common response to the perceived rise in the value of U.S. power and commitment that emerged from the Gulf War and the end of the Cold War was neither simply to bandwagon with, nor balance against, the United States, but to seek some measure of autonomy or limited independence. The purpose of this autonomy is not necessarily to oppose Washington's policies, but rather to acquire the political and strategic means to achieve at least some significant national objectives without reference to the United States, especially with respect to regional security issues. More importantly, some degree of autonomy provides nations with an ability to influence the American decision-making process, especially as it relates to issues of global war and peace. The search for autonomy from the United States is by no means new, but the Gulf War indicated that many states will have to find such autonomy through different means than they utilized during the Cold War.

As it did throughout the Cold War, France is attempting to set the standard for national autonomy, at least rhetorically, in the general context of Westem alliance solidarity. Given its experience with the Gulf War, when France found itself extremely dependent on the United States for intelligence, the French are determined "to be capable of evaluating a situation autonomously" so as to guarantee that "France will be able to make its contributions to the resolution of crises and the maintenance of peace when, where, and how she wishes." ${ }^{24}$ According to former Defense Minister Pierre Joxe: "The same reasons that led France to equip itself with an autonomous instrument of nuclear deterrence must now lead us to develop an autonomous capability for space observation." ${ }^{25}$ To be sure, France cannot afford to go this route alone; it therefore secks to preserve its 
autonomy from the United States in the broader framework of European political and military cooperation.

Israel's post-Gulf War policy provides an interesting example of the strategic reassessment that several important U.S. allies went through in 1991 and 1992. The Gulf War held a mixed message for the Israelis: it demonstrated the importance of close ties with the United States, while at the same time it revealed that Washington no longer placed the same value on Israel as a strategic ally given the end of the Cold War. Because of the fragility of the strategic relationship between the two countries, Israelis felt the need to reduce dependence on Washington, especially in the military arena. ${ }^{26}$ In this respect, the previous and current Israeli governments seem to have (re)learned an important lesson from the Gulf War: Israeli-U.S. relations, however developed and solid they may be, do not guarantee American support for the Israeli position in every case of a Middle East crisis. For instance, the fact that the United States rallied to Kuwait's defense was not read in Israel as proof of an American commitment to the security and well-being of all states in the regions. Former Defense Minister Arens, for example, expressed the widespread Israeli doubt that the world community, with the United States in the forefront, would have rushed to defend Israel. ${ }^{27}$

Immediately after the Gulf War, Israeli policy makers had a heightened awareness that Israel must develop an independent military force strong enough to enablc it to cope alone with all foreseeable threats. ${ }^{28}$ This meant, in particular, dealing with the SSM problem, which is currently the most acute military problem the Israelis face. This will require independent early warning as well as indigenous offensive (and possibly defensive) counters to Arab SSMs.

As with the French, however, the Israeli case also points up the boundaries of the search for autonomy/limited independence. The outcome of the 1992 Israeli election, and the subsequent change in government policy concerning the peace process, represented a major political accommodation to Amcrican Middle East policy (and resulted in the frecing up of the $\$ 10$ billion
U.S. loan guarantee). In the military arena, Israel is coming to the same realization faced by most U.S. allies: it is simply too expensive to pursue self-reliance in areas that would truly make a difference. Areas such as $\mathrm{C}^{3} \mathrm{I}$, ballistic missile defense, and logistics require enormous investments that are difficult to justify in the current economic and security climate, especially when it is possible to "plug in" to the much more extensive American capabilities (even if these capabilities come with an associated political price tag). There is evidence that Israel, upon reflection, may be inclined to work out a cooperative division of labor with the United States in some key sensitive areas, despite its initial post-Gulf impulse towards autonomy. The Israeli Defense Force can best spend its limited dollars if it can make certain assumptions about American capabilities being available.

As the Israeli case suggests, many states are being forced to review their more ambitious plans and rethink their desire for a degree of comfortable separation from Washington, at least in terms of security. This topic is covered more fully in the next chapter.

\section{Perceptions of U.S. Power: Enduring and Transitory}

Several major shifts in foreign perspectives of the United States have occurred since the end of the Gulf War. The international concern about excessive American activism and power has decreased substantially in light of the events of the past several years, although suspicions still linger in some important quarters.

Chinais an interesting reflection of this change. As noted above, the initial Chinese reaction to the war was profound anxiety about the overwhelming display of American military powerpower that would no longer be restrained by the Soviet Union. Over time, the Chinese leadership appear to have reached the conclusion that the Gulf War should be viewed as an aberration, in the sense that the United States lacks the power to enforce unipolarity. (Debate contin- 
ues in the PRC concerning whether Washington, especially under the new Clinton administration, is nevertheless inclined to pursue unipolarity.)

To be sure, from the standpoint of the Chinese leadership, the United States is admittedly the only superpower, in the sense that it is the only nation that can project force anywhere in the world and that is a player in every region. That does not mean that Washington is dominant everywhere, however. Also, the Chinese note factors that will constrain the exercise of U.S. power (e.g., the continued stagnation of the American economy and domestic problems as exemplified by the Los Angeles riots). There is residual Chinese respect for American economic and especially technological prowess, but the United States is viewed as being in relative economic decline, especially with respect to the dynamic Asian states.

The current Chinese view is thus that the international system is in transition, with some clear trends towards multipolarity, but that the United States has the greatest degrec of comprehensive power of any nation. The Chinese continue to debate the extent to which (and where) the United States will face constraints on itsintemational behavior. Recent developments, such as the F-16 sale to Taiwan and U.S. proposals for a Radio Frec Asia, still seem to suggest a more ambitious and threatening U.S. agenda and to question the PRC's postTiananmen Square damage-limiting strategy towards Washington.

The evolving West European view of the United States in the aftermath of the Gulf War suggests more of a reevaluation of American interests and intentions, rather than of American power. The initial view, as noted above, was that the war seemed to revalidate the importance of the United States to European security, and of the principal instrument of the U.S. guarantee, NATO. But for many Europcans, a comparison of the American policy toward the Gulf crisis with the crises in Yugoslavia suggests that the Americans have made a de facto decision that their vital intcrests are not now engaged on the European continent. In the absence of a clear and present great-power hegemonic threat such as that represented by the former Soviet Union, the American stake in Europe is not nearly as high as it is in the oil-rich Middle East.

To be sure, the Europeans themselves are deeply divided on the significance of Yugoslavia and whether military intervention would be wise. Nevertheless, there is a sense that the Americans could have "done something" in Yugoslavia and that Washington would have "done something" had the problem occurred in the Persian Gulf. For example, there is a view held by some German elites that early and substantial American military action in the Croatian phase of the conflict would have had an immenscly sobering effect on the Serbians, and thereby have changed the entire politicalmilitary dynamic of the crisis. ${ }^{29}$

The result of the European comparison of Yugoslavia and the Gulf is a belief that a strategic vacuum has emerged on the continent because of increasing American disengagement. It is unclear whether this vacuum is truly dangerous, but there is a frustration among many continental Europeans that the U.S. seems to oppose measures that might allow Europe to fill this vacuum, for example, with the FrancoGerman corps, at a time when the United States is unwilling to take the lead. A key assessment made by many Europeans, running contrary in part to the early lessons of the Gulf, is that if NATO cannot be used to address the problems in Yugoslavia, then its relevance (and that of its principal member, the United States) to European security must surely decline in important ways.

The Serbian leadership's assessment is quite interesting in this regard. For Belgrade, the United States is the single most important element in the international community, and significant military action by that community is politically and technically impossible without American backing. The United States is not strong enough, however, to act without the support of other key players. The Serbians took comfort in the fact that, because the United States did not assume a leadership role in the early stages of the Yugoslav crises, outside military intervention was unlikely if not impossible. The Croatians, in contrast, initially thought 
that a purely European military intervention was credible, but they were soon disabused of that notion. ${ }^{30}$

No serious doubts about short-term American power have emerged in the Middle East since the Gulf War; in fact, the dominance of U.S. global and regional power had been appreciated throughout the Middle East before the summer of 1990. This was true even in Iraq-Saddam's notorious February 1990 speech argued for the Arabs to act before the American-Israeli axis could take advantage of its increased power position after the end of the Cold War. The Gulf Wardidnevertheless serve to confirm American willingness toexercise its dominant power position to secure its interests in the Middle East. The depth and reliability of the American commitment to states such as Saudi Arabia had not been as clear before. As a study on Jordan's response to the Gulf War noted:

From the King's point of view, the willingness of the United States govemment to go to war for an Arab ally or a coalition of Arab allies, in this case primarily Saudi Arabia and Kuwait, bolstered [King] Hussein's trust of U.S. verve-an ironic private conclusion considering Jordan's alignment with Iraqduring the war. Jordan's interpretation of U.S. policy in Iran with the fall of the Shah in 1978-79, in Lcbanon with the ill-fated Marine deployment of 1982 84 , and with respect to the general fecklessness of the Iran-Contra affair, had led the King and his court to question not the capability of the U.S. military, but the spine, and sagacity of American political leadership ... The very firm and resolute - and ultimately successful-U.S. response to the invasion of Kuwait has gone a very long way toward restoring the King's confidence that, when push comes to shove, the United States still knows how to be bold in protection of its own interests and those of its allies. $^{31}$

States such as Saudi Arabia, Egypt, and Jordan no longer doubt that the United States would intervene again in the Gulf, becausc oil is a vital U.S. interest. The perception is rather one of genuine confusion about what the United States is really up to in the region.

In this sense, key pro-Western Arab allies in the Middle East have the opposite perception to that of the West Europeans: one of overly active, and erratic, U.S. involvement in their region. American policy toward Iraq since the war seems unsound to pro-Western Arab states like Saudi Arabia. From a regional standpoint, the Gulf War is not yet over, the overarching American objective should be stability, but U.S. policies - which are neither able to overthrow Saddam nor accommodate to his continued rule-seem to be promoting instability. There is, for example, genuine concern about the U.S. support for the Kurdish quasi-state in the north and the exclusion zone in southern Iraq, since many Arab countries fear that the United States is now bent on dismembering Iraq. They want to sec Saddam removed, but not through the dismemberment of the country.

At the same time, the Arab states are puzzled by the standards for U.S. intervention outside of the Gulf. There is considerable public outrage about American and European inaction in Bosnia. The West, it is widely felt, is letting Bosnia suffer because Bosnians are Muslims and the West would not intervene to protect Muslims from (Serbian) Christians, or at least wouldnot protect Muslims solong as oil was not present. The recent intervention in Somalia has further confused matters: why would the United States intervene to protect starving Muslims in the Hom of Africa, but not in Europe? The uswal Middle East penchant for conspiracy theories and Machiavellian plots has led to popular arguments that the Somalia intervention is really a cover for a U.S.-Egyptian move against Sudan's Islamic fundamentalist regime, or that it is somehow linked to the strategic control of the Red Sea. ${ }^{32}$

There is also considerable political uncertainty in the region about the mid-to long-term future-not all Middle Eastern states have accepted American global or regional hegemony; a new world order is not in place. The United States faces a constant problem in the Middle East: what reassures can also frighten. U.S. activism during the Gulf crisis and war, and 
since, points toward the seriousness of American commitments but also raises regional concem about unipolarity and lack of influence over U.S. policies. Among Arab states, the accession of a new American president heightens these concerns, in that Clinton could reverse Bush's relatively pro-Arab stance and become more activist in the human rights arcna.

This analysis raises the questions about the long-term endurance of the pro-Amcrican coalition among many Arab states that the Gulf War seemed to produce. In the vicw of Paul Jureidini and Ronald D. McLaurin:

Without question, the Gulf crisis and war led to fundamental change in the coalition patterns that existed prior to the crisis. . . At the samc time, alignments that emerged during the Gulf War may or may not survive the immediate post-crisis pcriod. The reasons of state that militated for certain political movements during the war were a function of priorities sct by the magnitude and nature of the crisis itself. The end of the crisis naturally brought about a shifting of priorities, even wherc general objectives remained unchanged, and this resorting of priorities suggests that wartime coalitions may prove as ephemeral and unrepresentative as those of the major allies during World War Il. ${ }^{33}$

In addition to shifting considerations of realpolitik that may affect the attitudes of key Arab governments toward the United States and each other, there is the as-yet unanswered issue of whether the split between Arab elites and the Arab "street" that seemed to be manifest during the war was a transient or enduring phenomenon.

\section{Declinist Perspectives}

The general perception that emerged from the Gulf War (as wcll as developments surrounding the end of the Cold War) was thus largely one of unique American strengths and a dominant U.S. power position. At the same time, foreign observers did note American weaknesses, particularly economic. A few states-especially those with antagonistic relations with the United States-magnified these problems to the point of anticipating Washington's decline. From this perspective, the Gulf War represented the last hurrah of fading power. Deeply-rooted trends in international relations towards multipolarity-trends that were evident long before the Gulf War-will reassert themselves once the political afterglow of the U.S. performance in Operation Desert Storm wears off.

The declinist perspective, consciously or not, borrows heavily from the popular American intellectual debate of the late 1980s about the longevity of American power. Tariq Aziz, for instance, argues that "the alleged American age lacks permanence, and is plagued by many factors of weakness and backwardness. . . Any decline in the American power-which is at its peak and can grow no further-would mean relative progress for the Arab forces." Two serious problems - the budget and trade deficits-"constitute the gravest internal threat to American military power and superior political posture. The world has never seen an empire capable of maintaining military and political hegemony without a firm and stable financial base." 34

Iraq obviously feels that the survival of Saddam Hussein and Iraq's successful resistance to some U.N. demands is further proof of American weakness.

The declinists, particularly those in the Middle East, also reject the notion that American "ideology" is ascendent. America is a declining moral as well as economic power; the United States' strategic position is solely dependent on its military capabilities, which is fragile and will erode over time. Leaders of the Pan-Islamic movements such as Sudan's Hasan al-Turabi and the exiled leaders of the Egyptian, Tunisian and Algerian movements have argued that American weakness is visible in its inability to remove Saddam, and directly attribute it to the moral weakness of the United States. Islamic movements sometimes claim that Iraq's secular Ba'thist ideology made it vulnerable to the Americans in the first place, and point to the fact 
that Iran has never been seriously hurt by U.S. sanctions in the post-Shah era despite its holding of American hostages for more than a year. The presumed conclusion is that Iran enjoys a moral superiority over the United States due to its Islamic ideology. This argument resonates strongly among the "fundamentalist" movements, which see the United States as their major enemy but also as something of a paper tiger. ${ }^{35}$

Declinist views ironically tend to be held by those states that feared a near-term U.S. drive to enforce ideological hegemony in the wake of the Gulf War (e.g., Iraq, Iran, Cuba, and to some extent China). The U.S. decline is not expected to manifest itself fully for another five to ten years, soit has only limited operational value for day-to-day policy making, even for those govermments and factions that claim toembrace this viewpoint. In the Middle East, there is some effort to "demarginalize" China as an offset to the United States, although this is widely regarded as wishful thinking at the moment.

The declinist perspective is obviously selfserving, but carries important implications if it gains wide credibility. For one thing, it is held by other potentially important foreign groups that are now not in power but that could become more prominent if domestic circumstances change (e.g., the Japanese nationalists). These nationalists, such as Shintaro Ishihara ("The Japan that Can Say No") contend that, with the end of the Cold War, the world has really become "nonpolar," and the notion of a unipolar world under American leadership is an illusion. (It should be stressed that this is decidedly not the view of the Japanese political mainstream.) According to the nationalists, however, the world is returning to a restoration of nincteenth century international politics, as seen from a Japanese perspective - a world without a clearstructure in which there is a high probability of chronic disorder. The other major powers (e.g., Russia and China) will be unlikely to support future Desert Storms. Japan has therefore reached a point when it must seriously think about and implement its own global policy, rather than continue to see the world through an American lens. ${ }^{36}$
In this light, Japan's financial contribution to the Pcrsian Gulf coalition was misguided; Japan should instead have dispatched military forces (e.g., two or three escort ships to protect oil tankers in the Gulf). Japan should also realize that it cnjoys leverage over the United States because its technology is an indispensable ingredient for American military effectiveness. Ishihara claims that of the 93 types of semiconductors that were used in stratcgically critical American weapons, all but one was manufactured in Japan. ${ }^{37}$

There is an interesting variant on the theme of emcrging multipolarity, as presented by a South Korean study on the implications of the Gulf War. ${ }^{38}$ According to this assessment, the United States will remain the only superpower for the foresceable future; the other contenders for superpower status-Germany, Japan, China, Russia, and united Europe - each have weaknesses that will prevent them from broadening their "power portfolio." That said, a U.S.centered unipolar system is neither possible nor desirable. The reduction of U.S. military capabilities seems inevitable given the collapse of the Soviet threat, domestic economic difficulties, and isolationist sentiments in the United States. The United States has no reason to serve as the world's policeman and pressures will accordingly grow for the economic superpowersGermany and Japan-to pull their own weight.

The current situation, which might be charactcrized as a unipolar world, is therefore unstable and will be transformed over the next decade into a U.S.-led, multipolar system. This system will be marked by increasing conflicts and arms buildups in the South, while the North is relatively pcaceful and engages in substantial disarmament. The existing alliance system will be loosened or will break down entirely, ushering in a new era of nonalignment during which regional balances of forces will become the essential factor in deterring regional conflicts. If the United States does intervene militarily in such conflicts, it will do so either unilaterally or by forming an ad hoc coalition with other concerned countries. Interdependence in such areas as cconomy, the environment, and natural resources will increase, but paradoxically on the 
security front a nation's independent capabilities will be more critical than beforc, according to this Korean perspective.

\section{The Bottom Line: The United States Still Matters}

There has been some rethinking and downgrading of American power in the aftermath of the Gulf War by foreign observers, but the United States is still regarded as the sole superpower-in short, the United States still matters. The fundamentals of American powerdescribed in this section are still appreciated by foreign observers, evcn if the "relative" quality of American global dominance is increasingly understood and acknowledged.

That said, there is a considerable international divergence concerning the character and duration of U.S. superpower status in light of Washington's post-Cold War interests and intentions. The most important change in view has come with respect to an increasing international uncertainty about U.S. goals and policies. Washington's actions, or lack thereof, since March 1991 have had a profound effect on how nations view the lasting importance of Operation Desert Shield/Storm, which the Bush administration clearly hoped would sct the tone of the "New World Order." By and large, foreign observers do not now believe that such an order has been or will be established by the United States, although some of the patterns created by the Gulf War, such as the precedent of intemational military intervention, will endure.

The uncertainty about American interests and intentions will obviously increase in light of the change in presidential administration. Some states, noting the reluctance of the Democratic party to support military action against Iraq, tend to be concemed that Clinton will be less activist and intemationalist than was Bush. Otherstates, noting Clinton's criticism of Bush's supposed lack of support for human rights in Iraq and Yugoslavia, are concemed that Clinton may be more activist and willing to intervene in "domestic" affairs. The Clinton administration may be quickly tested politically, if not militarily, as other states reevaluate whether the principal lesson of the Gulf War-the United States chose to matter-is still the case.

\section{Endnotes}

1. See, for example, David Earling, "Italy and the Gulf War," unpublished paper written for the CNSS Foreign Gulf War Lessons Learned Study, September 1991, p. 18.

2. Francois Heisbourg, "Quelles leçons stratégiques de la guerre du Golfe?" Politique Étrangère 56 (Summer 1991): 412.

3. Shahram Chubin, "Iran and the Lessons of the Gulf War 1991," unpublished paper written for the CNSS Foreign Gulf War Lessons Learned Study, November 1991, p. 33.

4. Ephraim Kam, "Gulf WarLessons Leamed by Egypt," unpublished paper written for the CNSS Foreign Gulf War Lessons Learned Study, March 1992, pp. 17-18.

5. Ibid., p. 18.

6. This does not mean that foreign elites rigorously apply definitions of "polarity" as defined by intemational relations theorists - merely that most are persuaded (or profess to be persuaded) that the United States is the dominant power in the post-Cold War world.

7. Cited by Juan del Aguila, "Cuba's Views of the Gulf War and its Aftermath," unpublished paper written for the CNSS Foreign Gulf War Lessons Learned Study, February 1992, p. 4.

8. Gcorge Joffe, "Libyan Reactions to the Conflict in the Gulf," unpublished paper written for the CNSS Gulf War Lessons Learned Study, July 1991, p. 11.

9. Cited by del Aguila, "Cuba's View of the Gulf War," p. 1.

10. Adam Garfinkle, "Gulf War Lessons Leamed by Foreign Nations: Jordan," unpublished paper written for the CNSS Foreign Gulf War Lessons Learned Study, July 1992, pp. 17-18. 
11. Domico Proenca, Jr., "Brazilian Perceptions of the Persian Gulf War of 1991: An Impressionistic View," unpublishod paper written for the CNSS Foreign Gulf War Lessons Leamed Study, November 1991, pp. 23-24.

12. Kam, "Gulf War Lessons Lcarned by Egypt," p. 1.

13. Andres Fontana, "GulfWarLessonsLearned by Foreign Nations: The Argentine Case," unpublished paper written for the CNSS Foreign Gulf War Lessons Learned Study, December 1991, pp. 15-16. Fontana notes, however, that this policy of moving closer to the United States was not universally supported in Argentina, and that it could be reversed by a future change in govermment.

14. Young Koo Cha, "Korean Assessment of the Gulf War Lessons," unpublished paper written for the CNSS Foreign Gulf War Lessons Learned Study, September 1991, p. 4.

15. Ishtiaq Hossain, "The Gulf War Lessons Leamed by Foreign Nations: Vietnam and the ASEAN States," unpublished paper written for the CNSS Foreign Gulf War Lessons Learned Study, March 1992, pp. 9-10.

16. Ibid., pp. 14-15. According to this author, although Indonesia continues to oppose the permanent presence of foreign troops/bases in the region, it welcomes the presence of American military forces on a temporary basis-defining temporary as a period of five to ten years.

17. Telephone interview with security specialist on South Asia, New Delhi, February 1993.

18. Telephone interview with security specialist on South Asia, February 10, 1993. However, the issue of technology transfer, particularly the dispute over the transfer of a cryogenic rocket engine from Russia to India, remains a barricr to improved U.S.Indian relations.

19. David S. Yost, "France and the Persian Gulf War: Political-Military Lessons
Lcarned," unpublished paper written for the CNSS Foreign Gulf War Lessons Lcarned Study, May 1992, p. 31.

20. Telephone interview with security specialist on South Asia, New Delhi, February 1993.

21. Telephone interview with security specialist on South Asia, February 10, 1993.

22. Telephone interview with security specialist on Asia, February 1993.

23. del Aguila, "Cuba's Views of the Gulf War," pp. 10-11.

24. Picrre Joxe speech at the Centre des Hautes Études de l'Armement, 10September 1991, cited in SIRPA Actualité no. 30, 13 September 1991, p. 38.

25. Pierre Joxe, "Defense et renseignement," Defense Nationale (July 1991), pp. 17-18 (cited), Ibid..

26. Reuven Pedhatzur, "Gulf War Lessons Learned by Israel," unpublished paper written for the CNSS Foreign Gulf War Lessons Leamed Study, January 1992, p. 2.

27. Ibid., p. 17.

28. Ibid., p. 25.

29. Interview with German security specialist, Washington DC, September 1992. Lawrence Eagleberger, then Deputy Secretary of State, and National Security Adviser Brent Scowcroft have since acknowledged that, in the summer and fall of 1991, a relatively modest collective intervention by the United States and other European countries, backed by the threat or use of force, might have headed off the later disasters. Such an intervention was not considered scriously at the time, however, and the former Bush administration of ficials claim to have received no encouragement from the Europeans on this score. Don Oberdorfer, "A Bloody Failure in the Balkans: Prompt Allied Action Might Have Prevented Factional Warfare," Washington Post, February 8, 1993.

30. James Gow, "Yugoslavia and Lessons from the Gulf War," unpublished paper written for the CNSS Gulf War Lessons Leamed Study, October 1992. 
31. Garfinkle, "Gulf War Lessons Lcamed by Foreign Nations: Jordan," pp. 13-14.

32. Some Chinese press accounts have also alleged that the Somalia intervention is not driven by humanitarian concerns, but rather by U.S. efforts to gain new military facilities near the Persian Gulf. Discussion with Chinese forcign policy specialist, Washington, DC, December 1992.

33. Paul A. Jureidini and Ronald McLaurin, Middle East Perceptions of and Reactions to the Gulf War (Springfield, VA: Abbott Associates, September 1991), pp. 13-14. This study provides an excellent overview of reactions of key Middle Easterm states during the first few months after the Gulf War.

34. Baghdad Republic of Iraq Radio Network, May 20, 1992, in FBIS-NES, May 21, 1992, pp. 19-20.
35. Commentsprovided by Michael Dunn,January 14, 1993.

36. This discussion of the Japanese nationalist perspective is taken from Mike $\mathbf{M}$. Mochizuki, "Japan and the Persian Gulf Crisis: The Lessons Learned," unpublished paper written for the CNSS Gulf War Lessons Learned Study, February 1992, pp. 12-18.

37. It should be noted that Ishihara's views on U.S. technology dependence are exaggerated and are not taken seriously by knowledgeable individuals on either side. Written comments provided by Gregg Rubinstein, April 1993.

38. Young Koo Cha, "Korean Assessment of the Gulf War Lessons," pp. 5-9. 


\section{Chapter Two: Military Power Matters}

The Gulf War indicated that the favorable change in Sovict power and intentions-and the subsequent demise of the USSR altogetherdid not mean that the international community was entering into a brave new world in which military power, and the capability to use force, was radically devalued.

Traditionally, war has been the ultimate arbiter of affairs among nations, but it has also been the means by which a hierarchy of powers is confirmed or established in the intemational system. Given the low and diminishing probability of war among the great powers in the nuclear age - and the supposed rise in the salience $\mathrm{Cf}$ economic power as the currency of international relations after the end of the Cold War-it was unclear in the summer of 1990 how a power hierarchy might be created, recognized, and enforced. The Gulf War had the effect, as noted in the previous chapter, of establishing the United States as the dominant world power. It also suggested to other powers, larger and smaller, steps that they might have to take to maintain or improve their position in the post-Cold War hierarchy.

The Gulf War demonstrated to foreign states the continied salience of military power in other ways-most notably in the context of various national needs to participate in, encourage, or deterinternational interventions in regional conflicts. Two types ot regional conflict-traditional wars amorig states and emerging struggles within existing states (religious, ethnic. etc.)were both in evioince in the Gu! fryisis, war, and aftermath. These became of demonstrable concem to the international community, and in particular to the major states.
Without the disciplining effect of the Cold War system of alignments, regional conflicts became more likely. The Gulf War experience therefore buttressed the decision by a number of important regional powers, especialiy in Asia, to improve their military capabilitics. In the case of Malaysia, for example, this will mean a quadrupling of the defense budget (to $\$ 3.88$ billion) over the next live years. Malaysia justifies this increase on the grounds that new forms of conflict may emerge after the end of the East-West conflict, particularly those involving disputed areas, such as existed between Iraq and Kuwait. The possibility of such conflicts is by no means purely theoretical: Malaysia is involved in scveral territorial disputes with China, Taiwan, Vietnam, Brunei, and the Philippines over the Spratly Islands in the South China Sta; with Indonesia over the islands of Sipadan ano Ligitan; and with Singapore over Pulau Batu Putih, also known as Pedra Branca. Like many other Asian-Pacific states, Malaysia also professes its concem over the development of China's military capability and the build-up of India's blue water navy.'

The Gulf War pointed to the inability of the major states to wall themselves off from regional conflicts, as at least arguably had been the case before the war. Interstate aggression in key regions, such as the Middle East, could obviously threaten vital material interests (e.g., oil). The proliferation of weapons of mass destruction and long-range delivery systems further raised the stake of such conflicts. Intrastate conflicts held out the risk of spillover effects, that is, "local" events could get out of control and involve the larger and more direct 
interests of external powers. Intrastate conflicts also raised humanitarian concerns and brought public opinion in the democracies into play, as was the case during Saddam's efforts to suppress the Kurdish rebellion in the wake of the Gulf War.

Then French Defense Minister Joxc cxpressed a French perspective on these problems when he referred to "new risks of long-lasting crises in near and distant theaters" in the Middle East and Africa and "perhaps tomorrow" in East-Central and Balkan Europe. Moreover, in the wake of the Gulf War, new developments in international humanitarian law, particularly the right to interfere in support of persecuted minorities, have opened "new perspectives" for French military requirements. ${ }^{2}$ In another venue, Joxe explained how this changed international environment could require the use of French military power:

In past decades our defense was conceived to respond to a clearly identified threat; [but] the simple, brutal and direct threat has become blurred. This threat has been replaced by risks that are innumerable, diverse, and geographically dispersed, and for this reason difficult to grasp and evaluate ... Our defense must bc adapted to crises of more and more varied forms. . . Today our country could be drawn into crises striking it indirectly and gradually but quite as gravely in its sccurity and independence as a direct military confrontation. ${ }^{3}$

In addition to highlighting the salience of regional conflicts, the Gulf War pointed to what many foreign observers regarded as an unexpectedly large gap in military capability between the major states and regional powers (or between major states and factions participating in intrastate conflicts). This indicated that military intervention can be a feasible, if not always desirable, option to deal with regional conflicts. The Gulf War qualified, if it did not completely eliminate, the Vietnam/Beirut/Afghanistan syndrome (i.e., the belief that extemal powers cannot successfully and economically deal with a determined and resourceful Third
World adversary on its own turf). Such views were by no means universal-the Vietnamese government, although impressed by the performance of Ame ican technology, seemed unpersuaded that a war such as that waged against Iraq would succeed against them. ${ }^{4}$ The following assessment, however, is much more typical:

The Egyptians assert that technological prowess has granted the United States the decisive conventional capabilities it had failed to achieve in the Vietnam war. It can be assumed, therefore, that in Egypt's assessment, the military success in the Gulf War, the internal public support the war gained within all members of the coalition, and especially in the United States, and above all the low number of casualties involved in it have contributed to further liberate the American administration and society from the constraints of the Vietnam syndrome. ${ }^{5}$

Some have argued that the end of the Cold War means that regional powers or intemal factions are no longer under the "discipline" (if not control) of their superpower patron, and hence that they are more likely to behave aggressively. But at the same time, the end of the Cold War also freed the extemal powers of the constraints that had been placed on regional intervention by fears of escalation. In the first test of how such a relationship would play itself out, the Gulf War suggested that the extcrnal powers secmed to come out much ahead militarily within thesc altcred strategic parameters.

To be sure, the Gulf War arguably represented such a unique set of conditions that a generalization of this sort might be misleading and dangerous. Still, for many foreign obse:vers, the weight of evidence had shifted to favor the external, intervening, high-tech power rather than a local state attempting to rely on factors such as terrain and political will. The more reluctance to date of the high-tech West to intervene against the low-tech Serbians in the Balkans may affect this perception-although a failure of Western military intervention would have an even greater impact. 
Perhaps most importantly, the Gulf War set a critical precedent that extemal military intervention in regional conflicts may well occur under international, not national or bilateral, auspices. This precedent was set by Washington's choice. The United States did so, from foreign perspectives, for several basic reasons that are likely to hold in future major crises. First, and most obvious, is the American need for financial support, which will be greatly facilitated by using international fora. Second, it can be expected that the United States, or other major powers seeking to lead an international coalition, will use multinational arrangements to provide domestic and intemational legitimacy for the threat or use of military force. Third, in many cases, intervention in some regional conflicts will be so challenging as to require the support of many other states, which support is often most readily called upon through an international mechanism. This supportincluding bases, over-flight rights, logistical support-may be necessary to apply decisive force (i.e., the ability to ensure a quick conflict with low casualties and low collateral damage). International support will be all the more necessary if another major power center besides the United States, Europe, for cxample, takes the lead.

Are such international auspices, however, merely seen by foreign states as a flag of convenience for the United States, as appeared to be the case during the Gulf War? The answer is yes and no. Yes, in the sense that the United States had the power to undertake Desert Storm without assembling an international coalition and that it is the only power physically capable of conducting such large-scalc operations in the future. ${ }^{6}$ Yes, also in the sense that many states want to encourage the belicf in the necessity for international cooperation, preciscly as a means of restraining American unilateralism, whatever the "objective" realitics might be. But foreign states do believe that the United States will use such international mechanisms to generate essential domestic and foreign lcgitimacy. If the United States were to fail to use such mechanisms, there is a sense that this would erode the long-term basis of American global leadership.

To sum up: the Gulf War demonstrated that military power matters because (1) regional inter- and intrastate conflicts are likely to occur in the emerging intemational environment; (2) such conflicts matter to powers outside the region; and (3) the use of external military power, probably organized under international auspices, can at least in some circumstances be threatened or used to affect the course or decide the outcome of regional conflicts. Various states, or parties or groups within states, are responding to this implication of the Gulf War in different ways according to their particular national or factional perspectives.

The majority of states, especially the major powers, are seeking to influence or control the process of international (or Amcrican) decision making that will lead up to the possible use of external force in regional interstate and intrastate conflicts. This includes influence over the conduct and aims of military action should force be used. Some states or factions - those that see themselves as potential targets of intemational military action-are seeking the means to dissuade or deter such intervention. Finally, other states or factions-those that see themselves as potential victims of local or regional aggression-are seeking to encourage international intervention. Of course, states or factions may fall into more than one category, depending on the particular circumstances at hand, but they tend to have overriding interests in pursuing one of these objectives. The perspective of each of these classes of states/factions on the importance of military power in light of the Gulf War is discussed below.

\section{Case Study: The Western European Response}

Prior to examining the specific national reactions, it is useful to examine the impact of the Gulf War on the question of a European defense and security identity. The notion of such an identity seemed to have a good deal of momen- 
tum in the summer of 1990, as part of a larger process of European intcgration that might lead to the creation of a new force in world politics comparable to that of the United States. Unfortunately for advocates of such an approach, the Gulf War revealed starkly the inadequacy of both European military capabilities and the Europeans' ability to organize what they do have.

Several major areas of European security/ defense weakness were revealed by the Gulf War. First, the entire crisis demonstrated a lack of a political consensus on European-wide interests and policies. The French and Italian diplomatic approach to Saddam differed from that of the Americans, and from other European states. Second, a German evaluation of the Gulf War noted the following deficiencies in European military capabilities as compared with those of the United States: $C^{3} I$ (e.g., surveillance and navigation satellites, reconnaissance and target acquisition, electronic data processing, and relay), modem guided and standoff weapons, night vision devices, long-range air transport assets, airborne refucling capabilities, and modern air defense systems. Each of these areas will be important for future out-of-area multinational operations. ${ }^{8}$

Third, Europe was not in a position, organizationally or by inclination, to coordinate the assets it did have. NATO proved to be of much more direct and indirect significance than was the Western European Union (WEU) in supporting military operations in the Gulf. (Of the WEU's most visible role in the Gulf, that of naval coordination, former French Defense Minister Joxe acknowledged that this "played only a supporting role in the preparation and conduct of the military operations." ${ }^{\text {"g }}$ ) Changing this situation will be very difficult. Defense budgets throughout Europe are declining, and Britain and France are to some extent locked in, fiscally and politically, by their commitment to national nuclearforces that are outside a European framework. Germany's conventional forces are configured almost exclusively for combat on the former Central Front and at present cannot move out of area (even if the political will to do so were present). Europe does not have the number of forces needed; the United States has a defense budget that is roughly twice that of Britain, France, and Germany combined.

The impetus for cohesion, as Francois Heisbourg wrote during the Gulf crisis, still exists:

When a logic of war prevails, as has been the case since the invasion of Kuwait by Iraq, diplomatic weight is directly correlated with the military capabilitics involved. The crisis demonstrates that only the European dimension would permit us to reach the critical mass: it is all the more necessary for us to make up the weight fully within a European framework. ${ }^{10}$

In the aftermath of the Gulf War, France has continued its efforts, with only limited success, to increase West European cohesion in sccurity affairs. As Heisbourg has also noted, the problcm is the nced to reconcile the security policies of "extroverted" countries like Britain and France, and "introverted" countries like Germany-a distinction that was made painfully clear during the Gulf crisis and war. " Europe therefore expects that any major out-of-area opcration will have to be conducted with the United States. NATO's enduring value, in this respect, will be a function of the infrastructure that facilitates a multinational response to a particular crisis. ${ }^{12}$ One of the purposes of a European entity such as the WEU would be to increase Europcan influence in the decisionmaking of a future coalition.

That said, the Gulf War appears to have cncouraged several West European states to adopt more "extroverted" policies, particularly in reaction to new security threats emerging on NATO's southern flank. Spain, Italy, and Turkey (if defined as "European") come to mind in this respect. In the case of Spain, the Gulf War triggered renewed concem about the danger posed by Islamic fundamentalism in the Maghreb. In the words of one Spanish military official: "Spain has gone from being the rear guard, to becoming the vanguard." The Spanish government used the occasion of the Gulf War to move public opinion towards acceptance of a more outward-looking foreign and defense 
policy. According to Prime Minister Felipe Gonzales: "Our country has never taken the responsibility of assuming its obligations with the other countries that surround it or those of the international community. In other words, we have been isolated and it is very difficult to change the psychology of isolation. We want to participate in the welfare of the European community." This change in national psychology was aided by the fact that Spain sent its own small naval detachment to support the U.N. embargo against Iraq, and that it played a critical logistical role in the deployment of U.S. forces to the Gulf. ${ }^{13}$

A critical question for the future of European security concems whether Gcrmany has learned similiar lessons, and is becoming more of an "extroverted" power. A similar question can be raised about Japan and Asian security. The follow section addresses the attitudes of these two key countries in the wake of the Gulf War.

\section{The Response of Major Military- Technical Powers: Germany and Japan}

This section cxamines the implications of the Gulf War for two aspiring major powers that, like Europe as a whole, found themselves unable to influence or participate in external intervention in regional conflicts. Pcrhaps most importantly, the Gulf War demonstrated to Germany and Japan that they could not translate their economic strength into greater international power and influence if they remained "introverted" states. Trying to remain aloof from regional political-military crises-as was the initial German and Japanese inclination after the invasion of Kuwait-proved to be both impractical and counter-productive. German and Japanese elites and mass public opinion were embarrassed by their slow and reluctant support of the U.N. during the Gulf crisis-as perceived by other states - and were upset by the unfavorable international reaction to this tardiness.

The conclusion reached by the Germans and Japanese is that monetary contributions to fu- ture international crisis management or military enforcement actions will not be sufficient. "Checkbook diplomacy" will not work; it will quickly turn into "taxation without representation," as it did during the Gulf crisis and war. There is a broad political agreement among the Germans and Japanese that they cannot remain one-dimensional (i.e., solely economic) powers. As a study on Italian reactions to the Gulf War noted:

State power in the intemational system will be in the future partly a function of the capability and political will of individual nations to participate in multinational military efforts. Those nations that refuse, or are unable to participate because of technological or personnel limitations, will be denied a seat at the table when decisions are made regarding future international security structures and policies. ${ }^{14}$

The Germans and Japanese are accordingly seeking ways to contribute to international peace and security besides providing money, while gaining corresponding influence over the process by which decisions about peace and security are made. Because the United States is the dominant global power, whose international position depends heavily on its unique military capability, this particularly means finding some way to gain leverage over American policy-up to and including the diplomatic means to dissuade the United States from undertaking military action.

Tokyo and Berlin could, in principle, attempt to gain this leverage by duplicating or at least emulating American military capability- "if military power still matters in the post-Cold War world, then let us become major military powers." This however is not regarded as a viable course. The domestic and international costs of unilateral remilitarization are seen as being far too high by most Germans and Japanese. In fact, defense budgets are expected to decline in both countries. Instead, Japan and Germany are searching for other means that will allow them to play in the political-strategic game now dominated by the United States. The goverming elites-and some in the opposition- 
seek to push outward gradually to establish new national interests and establish a wider range of acceptable behavior.

For at least a time after the Gulf War, the U.N. Security Council was seen as the best fora in which to gain international influence, and hence the growing interest on the part of Tokyo and Berlin for Security Council membership. But even if such membership is achieved, German and Japan governing elites belicve that they cannot advance their distinct interests unless they are also willing to support and participate in some form in military enforcement/peacekeeping activities. In fact, Security Council membershipmight depend on German and Japanese willingness tobecome more "normal" members of the international community in this respect. As Joseph Nye has written: "Japan's inability to provide personnel for the Gulf operation and the subsequent failure of the first peacekeeping bill in the Diet made many countries skeptical about whether Japan merited a role in the Security Council. The Dict's passage of a peacekeeping bill in the summer of 1992 was a turning point that quicted some of those concems." 15

By developing modest capabilities in the context of international military intervention or peacekeeping, Germany and Japan are also implicitly developing a national or regional military hedge in the event of deteriorating conditions in the international environment coupled with American withdrawal.

Germany. For Berlin, this process of normalization has to be viewed in the context of the huge domestic imperative to absorb the political and economic costs of unification, which remain the dominant fact in German politics. But measured steps have been taken to increase the German sphere of action. For example, one can cite deployments of German aircraft to Turkey (however reluctant) during the Gulf War, new German assertiveness in the initial stages of Yugoslav crisis, and attempts to amend or reinterpret the constitution to permit out-of region and out-of-area deployments in a multinational context. The Christian Democrats/Bavarian Christian Social Union (CDU/CSU) efforts to push out the parameters of the out-of- area debate have run into major opposition from the Social Democrats (SPD), public opinion, and significant portions of the Free Democrats (FDP). This split continues over the question of amending the constitution to allow German troops to take part in U.N. sanctioned combat operations. Nevertheless, at the moment, these divisions in the governing coalition appear to be tactical rather than fundamental in character: the CDU, CSU, and most of the FDP accept the nced for Germany to go beyond peacekeeping. ${ }^{16}$

In any case, the German military is seeking to develop rapid-reaction forces, and the Gulf War was influential in shaping plans for that force. NATO's new force structure, with its heavy emphasis on a Rapid Reaction Force, provides the Bundeswehr with a political basis on which to plan for out-of-area operations. A study by Thomas Enders and Michael Inacker also noted the often-heard words of German force planners: "Fortunately, we have Turkey in the Alliance; almost everything we need in order to project forces to eastern Turkey can be used in out-of-area operations as well."17

Any increased German assertiveness in the political-strategic arena cannot be undertaken unilaterally; it must be subsumed in a larger multinational framework. For Germany, this larger framework means both Europe (e.g., through the Franco-German corps) and continued close partnership with the United States and its principal security device in Europe, NATO. In this respect, German political elites seem to be reconsidering the value of the United $\mathrm{Na}$ tions, which seemed to be highly regarded immediately after the the Gulf War. The course of cvents in the former Yugoslavia have persuaded many Germans that, if a major crisis occurred in Poland or elsewhere in east-central Europe, the United Nations would not be the appropriate mechanism to manage the crisis.

Japan. The Gulf War, and its aftermath, had a profound influence on Japanese mainstream thinking about security. ${ }^{18}$ Together with a change in the geopolitical environment of northeast Asia (including the collapse of the Soviet Union and developments on the Korean peninsula), the war represented a formative event in the emergence of a major debate in Japan about 
its future role in the world. ${ }^{19}$ The Japanese were upset with the lack of consultation by the United States during the Gulf crisis and war, and were concerned with knowing against whom American military power might be next used. To become a serious player on the new global scene, Japanesc policy makers realized that economic power alone was not nearly as relevant as they had previously thought, and that new means had to be found to exert influence.

One of the central strategic messages for the Japanese political mainstream from the Gulf was that regional conflicts will require a broadening of Japan's security perspective beyond that of homeland defense to include collective security and arms control. ${ }^{20}$ (Some experts believe that this lesson from the Gulf War might have been short-lived if the Soviet threat had not disappeared later in 1991-that Tokyo might have tried to return to business as usual had the old, comfortable bipolar international system continued to exist.) The Japanese, for example, have begun to distribute foreign aid in part based on the extent to which a recipient nation exports arms; this criterion has already been used with respect to Indonesia, India, and Malaysia. Support for and participation in peacekeeping operations is another new mechanism being explored by Tokyo-less as a means of containing regional conflicts than to develop credibility with and leverage in the United Nations. One important goal is membership on the U.N. Security Council, as a mcans of ensuring that T'okyo's voice will be heard before the fact, that specific Japanese interests will bc addressed, that altematives to the use of military power are preferred, and that the "uncqual trcaties" imposed after World War II (such as the enemies' clause in the U.N. Charter) are removed.

For the Japanese, particularly with the growth of the North Korean nuclear and ballistic missile programs, the danger of regional conflicts is no longer theoretical or limited to other regions. (Tokyo is even concemed about the character of the future security system in northeast Asia when a modus vivendi is reached between North and South Korea, or when unification occurs.) The Japanese are increasingly anxious about what they perceive to be a high-technology arms race that is emerging in Southeast Asia. This arms race, which the Japanese see as being driven by China in light of Beijing's own lessons of the Gulf War, ${ }^{21}$ suggests that the world may be retuming to a nineteenth-century style pattem of conflict over resources.

In light of these regional dangers, the Japanese mainstream believes that it must accordingly interpret the constitution more flexibly to broaden the scope of Self-Defense Force (SDF) activities and contribute more actively to collective security. The dispatch of Japanese minesweepers to the Gulf after the war was an important political step in this regard, and it helped build support for the peacekeeping operations (PKO) bill. It demonstrated that Japanese military forces could operate usefully, responsibly, and appropriately outside of the home islands and waters. The Japanese swept for mines in Iranian territorial waters, something that was acceptable to both Tehran and Washington. Japanese policy makers were quite proud of this action, as it demonstrated that Japan could complement American military and diplomatic actions in regional hot-spots. ${ }^{22}$

Under the new PKO bill, the SDF will be able to provide noncombat support for U.N. peacekeeping activities; any military role is explicitly prohibited. The logical extension of this position is that the SDF should eventually be capable of participation in U.N.-sanctioned peace enforcement actions. This position is not yet accepted politically, but the Democratic Socialist Party (DSP) has recently come out in favor of revising the Japanese constitution to permit such a contribution. The DSP is the first opposition party to make such a shift, and was stimulated by a similar move towards the center on such issues by the German SPD. In fact, Japanese politicians and elites have paid close attention to the parallel debate in Germany on subjects like the Gulf War and Security Council membership.

From this mainstream perspective, Japan must not refuse to participate in future U.N. sanctioned enforcement operations such as the Gulf War-to do so could have the perverse effect of leading to a resurgence of Japanese militarism. By refusing to bear its full responsibilities as a 
great power, Japan could become increasingly isolated and the Japanese-American security relationship could break down, which might destabilize the security relationships in Asia and in turn strengthen those in Japan who want fullscale remilitarization.

The Japanese mainstream, however, is divided on how to define Japan's new global responsibilities. One viewpoint, which might be called great-powerintemationalism, would prefer to change the constitution to permit Japanese participation in multilateral peacekeeping and peace enforcement operations, whether or not those operations were sanctionedorcommanded by the United Nations. This line of thinking is associated with the so-called Ozawa Commission. A second position, which might be called civilian internationalism, would support participation in peace enforcement only under a U.N. Command. This position is linked with former Prime Minister Miyazawa. The Japanese pacifists, described below, are beginning to align with the civilian internationalists in this critical debate on Japan's security policy.

Concerning the critical subject of northeast Asian security, the civilian intemationalists have chosen to address the issue through the promotion of a regional security dialogue rather than military modemization. The United States is to participate fully in this dialogue, both to help shape the agenda and to provide the United States with a means to remain a key player in the Asian security game. Unlike the pacifists, the mainstream civilian internationalists are anxious to keep the United States in that game.

The political divisions about Japanese security policy are reflected in a debate about the future of the Japanese military. The Gulf War raised expectations in the Japanese Defense Agency (JDA) and the SDF about the type of equipment that would be required in the future to support a more ambitious Japanese role in global politics. From a more traditional geopolitical perspective, as articulated by the greatpower intemationalists, Japan should increase its military capability in light of the lessons of the Gulf, and in light of the changing situation in northeast Asia (potential instability in Korea, reductions in American forces, and a residual
Russian threat). This vicw, by and large, is losing influence rapidly. Instead, the JDA and the SDF are being pulled toward a much more modest capability centered around participation in U.N. activities. Advocates of this restructuring are looking to the Scandinavian militaries for examples and ideas. If this pattem holds, funding for the SDF will be legitimated largely through its potential U.N. role. Any acquisition of major new systems, such as airborne warning and control systems (AWACS), will be made principally for economic reasons or to satisfy the United States, and only secondarily to develop an autonomous military capability.

As with Israel and France, Japan found its intelligence capabilities lacking in the Gulf crisis and war, and was concemed about its general over-reliance on American intelligence. Most Japanese analysts, for example, presumed that there would be a peaceful negotiated settlement to the crisis, even as late as January $10,1991 .^{23}$ This failure involved not only analysis, but the structure of intelligence in Japan, since there was no single body that collects, compiles, or analyzes intelligence, either in the military or the national government. At the national level, the Ministry of Foreign Affairs Information Research and Planning Bureau was reorganized in the wake of the Gulf War into the International Information Bureau. The purpose of this reorganization was to centralize intelligence in the Japanese government, while providing it with better analysis. The Defense Agency, meanwhile, is merging its six research divisions into a single body; the creation of an intelligence headquarters (modeled after the U.S. Defense Intelligence Agency), which had been planned for 1995, was accelerated through the establishment of a "preparation group" in 1992. The SDF, however, reportedly still remains heavily dependent on the United States for the provision of military intelligence. ${ }^{24}$

There has been growing interest in a Japanese-controlled intelligence reconnaissance satcllitc. Projected Japanese civilian remote sensing satcllites, such as the Advanced Earth Observation Satellite (ALEOS), could, in principle, provide militarily useful products (with a resolution on the order of 8 meters), but it is 
unclear what links the Japanese intelligence community might have with these satellites. ${ }^{25}$ Interest in development of a dedicated intelli-. gence satellite is due, in part, to pressure from the Japanese satellite industry (which has proposed such a satellite, called "Hinomaru" or "Rising Sun"). But it is also due, in part, to a recognition that the SDF may need an autonomous reconnaissance capability, particularly as the United States draws down its forces in the western Pacific. This interest must however be balanced against the costs of such a satellite capability and its uncertain reception in Asia. ${ }^{26}$

Limits on Germany and Japan. The precise long-term direction of German and Japanese interests and policies is far from settled; there are still major disagreements among parties and factions. The Gulf War revealed fundamental lack of national consensus about post-Cold War interests and security policics for both Germany and Japan. As noted above, the governing parties in these countries are trying to become more assertive internationally in political-strategic affairs, including taking tentative steps to develop new tools of intervention. For Germany, this means the creation of rapid deployment forces for use in multinational operations. For Japan, this has meant the formation and employment of peacekeeping forces.

There is active and considerable opposition in Germany and Japan to these policies of "pushing out the security envelope" intonontraditional military or quasi-military rolcs. Even the political opposition favors greater activism and a morc outward-looking orientation, but the differences in means and outlook remain significant, and the long-term trajectory of Japanese and German security policy therefore remains highly uncertain.

For example, the Japanese pacifist approach calls for the development of a distinctive national contribution to international society in an age of collective leadership, and not for following the American lead or developing quasimilitary tools of influence. ${ }^{27}$ Pacifists are skeptical that American military action in the Persian Gulf and the plan for a New World Order will provide a genuine basis for peace and security -it will rather likely provoke further instability and undermine the scarch for politi- cal solutions to regional conflicts. Although the Gulf War showed that military power is still an overwhelming force in world affairs, Japan should act as a global civilian powerby cultivating nonmilitary contributions to intemational security. In this era of global economic interdependence, Japan can "stimulate the perception of the changing nature of power in the world and the recognition and acceptance of Japan as a new power" by emphasizing economic statecraft rather than military might. ${ }^{28}$

But even the pacifists recognize that Japan must also move beyond its preoccupation with its own economic growth by developing "a more multifaceted, values-oriented policy." ${ }^{29}$ For example, Japan could develop more vigorous policies regarding international peacekeeping, human rights and democratic development, and environmental protection. Without such efforts, the rest of the world is likely to interpret Japanese pacifism as just a reflection of national selfishness. In any case, the renunciation of war does not mean that Japanese citizens can forego thinking about security and the use of force in world affairs. The Gulf Warexperience demonstrated that in order to have a viable antiwar policy, even pacifists in Japan must reflect on security issues and seriously consider realistic measures for preventing and resolving conflicts.

In short, Japanese pacifists have moved away from isolationism, to advocate a new security policy that would formalize in law the legitimacy of defending the homeland. The SDF would be reconstituted for that sole mission, and a separate unit would be created to participate in U.N. bluc helmet operations. The ultimate goal would be the creation of a U.N. standing force in which no distinct national units existed.

The pacifists question whether Japan will continue to be able to adhcre to their pacifism and adopt this new security policy while still preserving the alliance with the United States. If the alliancc itself remains, a division of labor between Washington and Japan might emerge. In the view of Masaru Tamamoto:

While the United States concentrates on its military responsibilities, Japan can concentrate on its energy and resources on fostering economic development and encourag- 
ing an equitable distribution of wealth in the world. While foreign assistance in and of itself is no guarantor of world order and peace, neither is the reliance on force; both have their uses and limitations. ${ }^{30}$

Despite the major differences of vicw among Japanese elites and the public, the Persian Gulf War did provoke anation-wide agreement about one thing: It is time for Japan to play a greater role in international affairs commensurate with its economic capabilities. That will require Japan to develop some autonomy from the United States (although there is as yet no consensus about what exactly this might entail). It is therefore likely that, in the coming years, Japan will gingerly try to increase its degrees of freedom within an overall pro-American policy framework. The Gulf "shock" had thi effect of causing Japan to move forward and attempt to consolidate a position of leadership in Asia. One can anticipate a continuing shift in the Japanese "portfolio" toward greater emphasis on Asian regional cooperation and on the United Nations, with relatively less emphasis on the American connection. Japan might well seek to insist that future collective security policies be centered around the United Nations, or other multinational organizations in which Japan has influence, and not around the United States.

From Tokyo's standpoint, however, close ties with the United States and greater Japanese autonomy are not a zero-sum game. Japan will want to have to both ways: it can be much more of a responsible actor in both regional and global organizations while retaining tics to $W$ ashington that Tokyo believes will continue to be in its vital interest. ${ }^{31}$ Nevertheless, Japan's diversification of its security portfolio may accelerate if current fears about American disengagement from Asia take hold in Japanese elite opinion.

\section{The Response of "Aggressor" States or Factions}

This section summarizes the response of states or factions that are concemed that their actions or ambitions may trigger international military intervention, and that wish to dissuade or deter such intervention. The general approach of such states is to rely on political measures designed to reassure external powers (or at least obfuscate the situation), coupled with measured increases in select military capabilities to raise the price of intervention.

There is no indication that the Gulf War caused any state or faction to alter fundamentally its ambitions over the longer term. The war, combined with the loss of the Soviet counterweight, nevertheless had a clear "chilling effect" on states potentially hostile to American and Westem interests (for example, North Korea, Iran, Cuba and, of course, Iraq). The Libyans, for example, were reportedly warned by the Egyptians in August 1990 that Washington would not tolerate any Libyan radicalism and that support for Iraq would be avenged by the United States after the conflict. Libya then shifted its policy from one of trying to mobilize Arab opposition to "neo-imperialist U.S. intervention," to one of formal support for U.N. actions, and later to a position of neutrality. In Libya's case (as with Syria), the Gulf War only rcinforced or confirmed more cautious policies by such states that had already been adopted before the Gulf War. As George Joffe noted: "to take Iraq's side in the conflict would have been disastrous - the new rapprochement with Egypt would have been destroyed and Libya's diplomatic isolation reinforced. . .Libya's own vulnerability to military action was so evident in the wake of the April 1986 bombings that the Qadhafi regime really had nooption but to adopt a neutralist stance." 32

Conversations by American experts with North Korean scholars indicate that the major lesson North Korea's political decision makers took from the Gulf War was that Pyongyang could not afford to be targeted as a second Iraq. (The precisc military lessons of the Gulf War may have not been fully absorbed, however, by a highly compartmentalized North Korean military.) North Korea, therefore, decided to enter into significant agreements with South Korea regarding reconciliation and nonaggression and denuclearization of the Korean peninsula. It 
also signed the International Atomic Energy Agency (IAEA) safeguards agrcement in Vienna. Pyongyang has yet to implement inspections within either the IAEA or North-South Korea bilateral inspections regimes, however. This suggests that North Korea's apparent limited opening to the West after the Gulf War was purely tactical in character, designed to assuage the United States temporarily until Pyongyang could develop a better sense for how dangerous post-Gulf, post-Cold Waractivism by the United States might be. ${ }^{33}$

As noted above, the Gulf War and the end of the Cold Warled to fears among such states that U.S. activism wouldincrease, and that the United States would scek to impose a unipolar world. This has lead to or reinforced a rule of thumb: do not take actions that will provoke intemational intervention, especially those that would serve as a cover for U.S. military action. In the Cuban view, forexample, all international resistance to the United States has cracked and none of its former allies are now willing to confront Washington as had been the case in the past. With the end of bipolarity, there is no strategic protection for a small and vulnerable state facing an increasingly confident and aggressive superpower. Because U.S. imperialism is actively promoting capitalism and democracy on a global scale, Cuba must not provoke the colossus and make itself a target. ${ }^{34}$

There is a problem with following such a rule of thumb: these states or factions are currently uncertain about the precise threshold for triggering international military action. In the Mahgreb, for example, intemational relations are seen as being intensely personal; in both the popular and elite view, the second Gulf Warwas the result of "Bush getting mad at Saddam," just as Reagan had "gotten mad" and bombed Libya four years previously. ${ }^{35}$ For the moment, potentially hostile states are tending to err on the side of caution while probing to determine where "red lines" exist. One can sce this phenomenon at work today in Iraq, Iran, Libya, Syria, Cuba, North Korea, and, to limited degree, Serbia.

To some extent, the leaders of these antiWestern states may play upon their international isolation and weakness to strengthen their domestic hand. With respect to Cuba, for instance:

The allied victory in the Gulf and the failed coup against Gorbachev, which Castro supported, confirmed his worst expectations. As a result, he makes Cuba an outcast, a role which he and others relish. After all, it reinforces a siege mentality at home and plays upon the David vs. Goliath syndrome. In a perverted sense it is used by the regime in order to motivate people, on the grounds that Cuba is alone and threatened. ${ }^{36}$

There are still self-perceived opportunities for Cuba to get back into the international game. The declining utility of "military intemationalism" in a world dominated by its principal enemy has forced Cuba to shift the struggle to the symbolic level. Without the support once provided by Moscow, Cuba cannot intervene in regional conflicts as it did in the 1970s and 1980s; neither can it provoke a strategic confrontation with the United States without the strategic protection once afforded by the communist bloc. But the struggle will go on through othermeans, and Cuba's quiver is not yet empty. Ideas, convictions, and honor are powerful weapons that, in Castro's mind, revolutionary Cuba still possesses. Castro therefore substitutes verbal and symbolic rhetoric for political or strategic confrontation, keeps his power dry, and dreams of recapturing past glories. The opportunities could emerge because international conflict may well become more rather than less likely in the short and medium term and because it is not yet clear how effectively the United States and its partners are going to manage the new world order. Castro observes that "now the Yankees believe themselves to be masters of the world. We'll see if this world can be govemed, that is the first thing that we have to see, because it is characterized by colossal problems, and imperialism's global ambitions are sheer lunacy."37

For its part, the Libyan government feels that the Gulf War demonstrated its essential marginalization in international relations. Tripoli "may then seek less orthodox ways of making its presence fclt in the intemational 
arena. In short, the regime may feel impelled to fall back on support for international terrorism in order to influence regional events." 38 But, of course, this runs the risk of triggering international, and specifically American, reprisals. As a consequence, Libya may instead scek regional allies (e.g., the recent rapprochement with Egypt).

Thus, it should be emphasized that potentially hostile states have not abandoned their external ambitions, but they are seeking (or continuing to seek) more subtle and long-term means of achieving them. From the perspective of Syria's Hafez Assad, for example, Saddam Hussein drew exactly the wrong lessons from the American withdrawal from Beirut in 1983. By taking on the United States directly by invading Kuwait, Iraq courted disaster. The Syrians believe that their approach to gaining greater regional power is more subtle and hence more effective-witness Syria's gradual establishment of control over Lcbanon, which came in the end with de facto American blessing. Saddam Hussein's style is to rob banks; Assad's style is to establish protection rackets. The latter may become an increasingly preferred course for ambitious Middle Eastern states who have learned the lessons of the second Gulf War. ${ }^{39}$

One of the most common means of hedging against international pressure involves the creation of national self-reliance in key industrial and military sectors to avoid or minimize the effects of international embargoes, and to minimize the influence of great powers (even ostensible patrons) on national decision making. North Korea, with its philosophy of juche, is perhaps the best example of this impulse towards technological and industrial independence. The creation of an indigenous arms industry is often seen as an integral, indeed leading, part of a broad strategy of industrialization. Efforts by the United States or other major powers to deny military technology (e.g., ballistic missiles) to these states is interpreted as efforts to deny national independence in this larger sense.

To be sure, complete independence will be difficult to achieve. This has led to the formation of "pariah internationals" to work around the technology-transfer constraints that exter- nal powers may try to impose. It has also led to the scarch for a diversity of sources. This leads to an obvious difficulty, in that a diversity of sources is not easily reconciled with the imperatives of standardization for ease of maintenance and logistics.

For the most part, these steps are not aimed at directly countering a future Operation Desert Storm, but are rather political means designed to reduce the likclihood of external military intervention. Some states and factions are, however, contemplating means to raise the perceived costs of intervention by the advanced military powers in hopes of deterring intervention even if political strategies are not successful. The potential military-technical counters to international military intervention are discussed in the following section. But one area is worthy of particular note in this section on deterrence: weapons of mass destruction and long-range means of delivery (especially ballistic missiles). Some key states that fit the "aggressor" category-Iraq, Iran, North Korea, Libya, and Syria-have placed increased priority on weapons of mass destruction and ballistic missiles after the Gulf War.

The remark of a retired Indian Army Chief of Staff on the lesson of the Gulf-."Don't fight the Americans without nuclearweapons"--has been widely cited as being indicative of the thinking of Third World states on this issuc. A more representative Indian formulation might be stated as follows: If a state has nuclear weapons, it may not need to fight the Americans (or other great powers). In the past, India relied on the 1971 Indo-USSR treaty to ensure that there would be no external military intervention in a conflict involving Delhi (c.g., Chinese intervention in an Indian-Pakistani war). With the dissolution of the USSR, this insurance policy is no longer possible; therefore, India sees nuclear weapons filling the deterrent role of locking out external powers from a bilateral conflict. The Indian ballistic missile program is designed to provide regional, and eventually intercontinental, nuclear delivery systems that can reach the homeland of external powers. From the Gulf War, India therefore took away the negative 
lesson that, if Saddam had nuclear weapons, the reaction in the West to the invasion of Kuwait would have been quite different and not as clearcut. ${ }^{40}$

Besides their potential deterrent effect on the United States and other external powers, there are, of course, a number of other reasons to acquire weapons of mass destruction, for example, regional prestigc. For some states, international organizations and agreements (e.g., the United Nations, the nonproliferation treaty) are run by and for the great powers. Small countries must get around these agreements in order to buy themselves a place at the table of the great powers, and nuclear weapons, especially in light of the Gulf War, are seen as an important way to do this. ${ }^{41}$

Nevertheless, calculating the costs and benefits of trying to obtain nuclear weapons is a complex exercise even for the most anti-Westemstates. Such programs are two-edged swords: nuclear weapons might conceivably deter international intervention, but they might also serve as a lightning rod for external military action designed to preempt such programs, or as an excuse for outside intervention in local or regional conflicts. They are also very expensive, especially if pursued on the scale of Saddam Hussein's program. Would-be proliferators will undoubtedly observe how the United States and the United Nations follow up in Iraq in the aftermath of the Gulf War, and how other potential nuclear powers, such as North Korea, are treated.

\section{Case Study: Iraq}

How is Iraq adjusting to its military defeat in the war? To some extent, the Iraqi regime is trying to claim that the war was a political victory; that is, Baghdad seeks to deny that military power ultimately matters in relations between great and small powers. (In fact, Iraq's military strategy in the war had as its ultimate objective the survival of the regime, if all else failed.) As the quotes below from senior Iraqi officials claim, Saddam survived; therefore, he won.
This [the Gulf War] is the first time the Arabs go to war on such a scale, with a single Arab country on onc side and most important Western countrics, in terms of human resources and capabilities, on the other. And yet, the leadership and the policy remained alive. ${ }^{42}$

We must be cautious here and not fall into the trap of analysis of a narrow technical nature. The important thing is not to be defeated politically. ${ }^{43}$

President Bush's defeat in the 1992 election will strengthen the image that Saddam won-for Saddam, and many Arabs, the Gulf War was primarily viewed in terms of an intensely personal contest between the two.

Saddam's postwar strategy is predicated on the assumption that American regional dominance, built on waning military power, is a transitory phenomenon; that the United States will decline over the next five to ten years; and that the weakening of the United States will result in a multipolar world in which new centers of power will emerge to check Washington, thereby providing Iraq with much greater freedom of action. Time, by this logic, is on Saddam's side. He seems determined to outlast the West in a contest of wills. This requires him to stand firm against the U.N.-imposed sanctions and inspection regime so as to consolidate his political victory over President Bush. Such a policy must however be done without triggering a major U.S. military response. Saddam is therefore attempting to develop a refined sense for the exact threshold that would trigger U.S. military action. Saddam cannot simply wait out the sanctions. He must to some extent continue to defy and challenge the West, or he may lose the image of absolute power and ruthlessness which helps maintain his power at home, despite widespread internal opposition.

With this in mind, the January 1993 contretemps between Iraq and the United States was a political, not primarily a military, encounter. Saddam was secking to remind the world that he is still in office, and that George Bush was leaving it. He may also have been secking to remove the mask of United Nations supervision 
of the ceasefire by humiliating the United $\mathrm{Na}$ tions and forcing the United States, in its own right, to retaliate. The fact that 200 unarmed Iraqis managed to seize Silkworm missiles from U.N. guards inside Kuwait, demonstrating that the United Nations could not even protect captured munitions, undermines the official role of the U.N. as the guarantor of the ceasefire.

Importantly, Saddam tested the limits of U.S. patience without suffering a severc retaliation. The limited U.S. strikes in January 1993 did not hurt Saddam badly; he successfully determined precisely how farthe outgoing Bush administration could be pushed, without disastrous results to himself. Saddam can be expected to test the Clinton administration as well. Iraqis as well as Iranians remember the inability of the Carter administration to deal with the Iranian hostage crisis effectively, and Baghdad will likely seek to determine the resolve of the new administration at the first opportunity. In this respect, Saddam's reaction to the June 1993 U.S. strike against the headquarters of the Iraqi Intelligence Service will be a crucial indicator of his assessment of the new American president.

Domestically, the imperative to preserve the Ba'thist regime has increased, if that is possible, in the context of a recognition that the Iraqi economy and industry must be revitalized. Barzan al-Tikriti, Saddam's brother, in his critique of the Soviet Union's collapse, has remarked that:

It goes without saying that superpowers, and also small powers, are based on four major pillars, which necessarily should be balanced. These pillars are:

-A strong economy

- Strong social coherence and harmony

-A strong consensus on a specific national objective

-An armed force and the forces' capabilities.

Thus we see that the Soviet Union placed the fourth factorin first place, while the first factor was ranked last. Perhaps this has been one cause of the retreat of the Soviet Union. It is difficult to imagine building without an economic foundation. . The
Soviet Union collapsed because of its weak economy, despite its mammoth military power. ${ }^{44}$

In the aftermath of the Gulf War, Saddam appears to have chosen the Chinese model (repression to quell unrest, while allowing for a dcgree of economic freedom) over the Soviet model (political liberalization) to rebuild Iraq's economic strength. (To be sure, the Iraqi economy has now suffered from two and onehalf years of sanctions and is unlikely to enjoy the opportunity for economic reconstruction any time soon.) Recent Iraqi writings, including speeches by Saddam himself, have focused on the notion that capitalism is separable from westem liberal democracy, and that western liberal democracy presents a threat to Iraq and the region. As part of his domestic crackdown, Saddam has purged the officer corps of those who were politically suspect or had failed during the war; this reinforced the positions of the Takritis and other Sunni Arabs in the military. ${ }^{45}$ By the same token, the size of the Ba'th Party has been reduced through an imposed reduction in membership.

Saddam's Confession? Did Saddam leam the obvious political-military lessons of the Gulf War that were widely noted by American and foreign observers? There is no direct evidence on this score, but Iraqi opposition sources have reported a $\mathrm{Ba}^{\prime}$ th Party meeting early in 1992 where Saddam supposedly made the following admission of errors. ${ }^{46}$

First, it was a mistake to "waste time and effor settling the domestic issues in Kuwait" and not occupying the eastem province of Saudi Arabia and mining its oil wells. Even if international pressure had been exerted and military threats made, it would have been possible to wait for the coalition forces to arrive and then make a bargain linking Iraqi withdrawal from Saudi Arabia to acceptance of Saddam's occupation of Kuwait. (Saddam's original logic in not pushing on into Saudi Arabia seems to have been linked to the belief that such a threat to Saudi Arabia would surely provoke an international response, whereas the occupation of $\mathrm{Ku}$ wait alone would not.) 
Second, it was a mistake to release the Westem hostages. Saddam supposedly claimed that Austrian President Kurt Waldheim had convinced him that their release would calm Europe and ease intemational pressure against Iraq. The third mistake was in not attacking U.S. troops when they first arrived in the region. Under these circumstances the Iraqis could have inflictedheavy casualties, thereby creating pressures for the withdrawal of coalition forces from the "new Vietnam." Fourth, Saddam placed too great a reliance on Soviet President Gorbachev and French President Mitterrand; this led to an indecisive Iraqi stand.

Finally, Saddam supposedly ciaimed to have been deceived by Iranian treachery: following Iraoi concessions in retuming territory to Iran, the Iranians supported the rebellion in southem Irac. Saddam claimed that this rehs! lion forced him to choose between Basra and Kuwail, and under these circumstances he had no choice but to fight for Basra.

\section{Serbia: A Case Study of Dissuading/Deterring Military Intervention}

In recent months, the "Serbian camp" in Belgrade has clearly attempted to usiderstand and influence the threshold of external military intervention. ${ }^{47}$

According to James Gow, in the spring and summer of 1991, the military-pclitical elite in Belgrade began a series of studies both of the Yugoslav crisis in the context of the "New World Order," and of the international community's intervention in the Gulf. These studies were carried out explicitly for the purposes of comparison: The Yugoslav People's Army (YPA) wanted ts determine if Belgrade would find itself in the same position as Baghcad. A selection of thes' studics were published in the leading YPA military-theorctical joumal (Vojno Delo); they came to the conclusion that the Gulf War was unique, and that it would not be repeated in the Balkans.
To begin with, YPA analysts argued that the Gulf War was critical to study as "a true paradigm for the use of modem technology and a credible model for the use of force in a hypothetical warin similar political-military circumstances, something which (with reference to our crisis and its possible intemationalization) cannot leave us indifferent." The Gulf War "could be a model for the instrumentalization of the $\mathrm{UN}$, as a system of global collective security, serving to realize the global strategic interests of the greatest world powers." 48

The use of American, British, and French troops to provide protection to the Kurds in northerm Iraq at the end of the Gulf War was noted by these YPA analyses-as were concomitant Security Council efforts to address questions of human and ethmic rights and to make a connection between internal conflicts and threats to international peace. This suggested that the events in the Gulf, particularly the emphasis on the extension of humanitarian considerations, could constitute a type of "neoimperialism" by the great powers, perhaps triggering intervention against Serbia in the ongoing Yugoslav conflicts.

That said, it was clear to the Serbians in the summer and fall of 1991 that the five permanent members of the U.N. Security Council had quite different perspectives on the Yugoslav question (unlike the Gulf). The Gulf War had also revealed that armed international action required U.S. leadership; neither the Europeans nor anyone else could intervene militarily without U.S. backing - and the United States was not exercising a leading role at that time. In addition, th: Gulf War suggested to the Serbs that militar y intervention was likely only if there was a tang ble international interest, such as oil, at stake. 7 herefore, Belgrade determined that, although there was reason to be concemed about outside interference, international military action was not in the cards.

This judgment was revisited in the "ring of 1992 , as intemational opinion grew rnore hostile to Serbia and as the United States became increasingly involved - it then appeared to the Serbs that some form of military intervention 
might actually occur. At that time, Washington first took the lead in obtaining a series of U.N. Security Council resolutions against Belgrade, offering similarities with the pattem of events that preceded the Gulf War.

The Serbian response to greater American activism was in part military-it focused on how to deal with the use of American air power against Yugoslav (Serbian) forces and against Belgrade itself. The YPA explicitly noted the unprecedented, and prolonged, air campaign in the Gulf, and accordingly emphasized the upgrading of air defenses around Beigrade totry to impose heavy losses on the attacker. The Serbians spoke of imposing enemy air losses of 50 percent or higher, but this may have been more to reassure the population rather than a real assessment of Serbian air defense capabilities. In fact, the entire publicity campaign by the Milosevic regime, concerning both the threat of a U.N. attack and stepped-up air raid precautions, could have been designed to manipulate popular fears and thereby consolidate support for the regime, rather than as evidence that the Serbian government shared these appreher sions. ${ }^{49}$

The most important Serbian response, however, was political. From the Gulf War, the Serbians took the lesson of the need to avoid intemational isolation. In the post-Cold War environment, Serbia could not necessarily hope to rely on "traditional" good relations with states like France, but it could make every effor topersuade potential members of an anti-Serbian alliance that it was not in their interest to back such a coalition. First, Serbian officials and media suggested that the international intervention force would become bogged down in guerrilla war. Second, there was an attempt to disguise Belgrade's military role and create the impression of a chaotic, uncontrollable ethnic war, an intemational intervention force would not only become bogged down militarily, it would be caught in an incomprehensible political maelstrom. (This argument had the added benefit of being arguably true.) Finally, the Serbians, along with the other parts of the former Yugoslavia, recognized that the United States was the most important single actor in determining whether international military intervention would take place; this put a premium for Belgrade on improving relations with Washington. The appointment of an American citizen (Panic) as prime minister of the ncwly-declarcd Yugoslavia may be judged as part of this effor to show a good face towards the United States.

Serbia's political strategy required more effective use of the media than Saddam Husscin exercised in Kuwait, or that the Serbians were able to use during the Slovenian and Croatian phases of the war. The 1991 Vojno Delo studies of the Gulf War had pointed to the importance of developing good relations with a "pool" of suitably "informed" journalists. The leader of the Serbs in Bosnia (Karadzic) accordingly tried to seize the media initiative, giving frequent press briefings and interviews, sending letters to The Times in London, as well as allowing reporters access to the military units ostensibly under his control. Karadzic's kcy message for the Western press played down the image of a war between forces loyal to the Bosnian govemment and insurgents controlled in Belgrade, and played up the image of a maelstrom of ethnic hostilities. Even Panic wamed that any military intervention would mean Vietnam all over again for the United States.

There is strong evidence that the Serbian camp has been careful that its actions remain bclow the threshold of provoking unacceptablc international pressure, particularly an armed intervention. As noted above, Belgrade assumes that this threshold is much higher in the case of Yugoslavia than was true in the Gulf, given the lack of overriding material interests from the standpoint of the international community. At those points in the crisis when international intervention secmed most likely (September 1991, spring 1992, and spring 1993) the Serbian camp made apparent concessions to the international community, however tactical in character. These tactical concessions went quite far in the spring of 1993, when Milosevic agreed to cut off military supplies to the Bosnian Scrbs and to allow U.N. monitoring of this action. However, when Milosevic became convinced that the United States could not arrange 
for international military intervention to support the Vance-Owen peacc plan, these concessions were just as quickly dropped. This pattern of U.S. military threats, followed by inaction by the international community, has reportedly persuaded Belgrade that American intervention is not to be feared under the present circumstances. ${ }^{50}$

The overall assessment of the Serbian camp seems to have been that there was little likelihood that the intemational community would be able and prepared to intervene militarily in Croatia and in Bosnia and Herzegovina. However, Belgrade is not as certain about whether violence in Kosovo would prompt intemational armed intervention; on balance, it appears that the Serbian leadership currently believes that action in Kosovo, including incursions into Albariia and Macedonia, will probably not result in an armed intervention. Belgrade has apparently calculated that it can wcather international opposition (e.g., sanctions) as long as it is not military in character. However, the Serbian camp has worked to avoid incurring international political and economic sanctions, which accounted in part for the acceptance of Panic as Yugoslavian prime minister. The fact that Panic was not able to end this intemational pressure (although he has made a good impression abroad and may have prevented further actions from being taken against Belgrade) certainly contributed to his political demise.

\section{Case Study: Iran}

Iran represents an example of how a Third World state is adjusting to the clear military superiority of external powers, and the need to avoid war with those powers in the short to medium term, while continuing to pursue ambitious national objectives. $^{51}$

Any assessment of Iranian perspectives on the 1991 Gulf War must begin with an acknowledgement that there is more than one important "Iranian" view. Wcstemexperts tend to divide Iran's most significant internal factions into two camps-pragmatists/moderates/ technocrats on the one hand, and radicals (led by the conservative clerics) on the other. There is however no consensus among Westem experts as to the precise lines of demarcation between these factions, which faction holds the upper hand on any given issue, or the long-term political prospects for Iran. This uncertainty makes it difficult to arrive at any definitive judgment about Iran and the second Gulf War. The following analysis does not clearly distinguish between the two factions in most cases, but rather suggests that "Iranian" perceptions of the 1991 Gulf War represent an amalgam of views.

This said, most Iranians seem to share the general international perception that the United States, no longer constrained by East-West competition, is enjoying a period of unrivaled international influence in the wake of the 1991 Gulf War. The Iranian expectation is that Washington will seek to establish some form of direct or indirect presence in or around the Gulf, and that this policy is intended to contain Iran diplomatically. Among its other objectives, the United States has an interest in keeping oil prices down (whereas Iran typically seeks to increase the price), a policy that it will pursue through the agency of Saudi Arabia. U.S. power is viewed by the Iranians as a constraint on theirmaneuverability in the region. Iran feels that the United States is trying to use the Islamic fundamentalist threat as a replacement for communism as a means of justifying its global status and overwhelming military power.

The second Gulf War largely removed the "paper tiger" image of the United States in Iranian minds; this image had been a key factor in influencing Iranian policy since the Revolution. It had been an article of faith for Iran that the power of the "super" or "arrogant" powers was largely a myth that could be exposed if tackled properly. This meant dealing with outside powers in unconventional ways and seeking theirvulnerabilities as the Vietnamese had done. (In the mid-1980s some in Iran thought that by sponsoring terrorism against the West they had found the chink in the armor of those powers that seemed to dominate the intemational order.) American actions during the first Gulf Warincluding the naval escort of reflagged tank- 
ers-had not dissuaded the Iranians from believing that the Vietnam syndrome still held.

This change in the perception of the United States brought about by the Gulf War reinforced a preexisting Iranian decision to buy time, without abandoning longer-term goals. This orientation was based on the perceived need to rebuild domestic and military infrastructure after the Iran-Iraq War, as well as to address serious intemal difficulties caused by factors such as a population explosion. But Iran has by no means turned completely inward: it remains an unsatisfied power, frustrated by the lack of influence and weight that it believes its stature merits. Iran is still opposed to the unjust international order it sees dominated by the rich, arrogant, and selfish powers. In terms of regional ambitions its interests tend to be defined more as intangible "influence" than as claims to concrete or specific pieces of territory or resources.

Iran is currently confronted with serious economic and domestic difficulties. Tehran is thus inclined to pursue "defense on the cheap" wherever possible, as exemplified by the opportunistic purchase of Russian hardware. This should not, however, be confused with a willingness to accept a cheap (i.e., second-rate) defensive capability. Although the outcome of the second Gulf War provided a breathing space vis a vis Iraq, it did not justify slowing down or changing the direction of Iran's current military planning, which was originally set out after the first Gulf War. This direction is discussed below.

Iran assumes the importance of developing a domestic industrial-technological infrastructure-driven by the requirement for military security-that in the long run can lay the foundations for comprehensive national power. The Iranians are determined that any future American-led "Operation Staunch" will not be effective against them. Tehran believes that its comparative regional advantages - its size and relative social unity - can be enhanced through the development of a modern, self-sufficient industrial base. The Iranians understand that they can never be completely independent, but neither do they want to rely on the great powers for military hardware. This points to the con- tinuation and deepening of Iran's cooperation with other regional "misfits" (North Korea, PRC, Syrian, Pakistan, and Cuba). Russia also is becoming an increasingly valued source of arms, as the Iranians explore the possibility of undertaking joint ventures with Russia that will allow for technology transfer.

Iran has adopted a national security strategy to achieve these ends of avoiding war with the great powers while simultaneously enhancing its regional prestige and influence. The elements of this strategy are diplomacy, deterrence, and covert political action. Specialists on Iran disagree about the relative importance that Tehran places on these three elements. Some experts believe that Iran is moving towards a more confrontational stance and that there are limits to the Iranian move towards acceptance of international norms of behavior (e.g., with respect to support for terrorism). Still, most specialists agree that Tehran will seek to avoid a major crisis, and especially military conflict, with the United States or any of its regional allies for the time being, and that Iranian policy is designed to avoid such circumstances. That is not to say that Iran might not miscalculate the threshold of American tolerance, only that it does not intend to provoke Washington.

The first element of Iran's strategy-diplomacy-reflects in part the widespread Iranian belicf that Iraq's blatant and crude aggression against Kuwait more or less triggered an inevitable intemational reaction. If Saddam had approached the problem differently, subtly or in stages-for example, by slicing off of northem Kuwait or simply by the demonstrative use of force (invasion and rapid withdrawal)--Iraq could have avoided the consequences and gained all the benefits of its superior military power. To avoid Saddam's mistake, Iran is seeking to build regional relations and thereby break out of its international isolation.

Iran's current "charm offensive" toward regional and outside powers began after the end of the first Gulf War and has intensified following the second. It is exemplified by the release of the hostages in Lebanon; improved ties with Europe, the Gulf Cooperation Council (GCC), and cspecially Saudi Arabia; and restraint in the 
Hadj. With the defeat of Iraq, the Persian Gulf seems relativcly stable to Tchran; because there is no imminent or urgent threat there, Iran can afford toplay for time. Iran is therefore attempting to reassure the littoral states and build on minimum common areas of cooperation, while setting more contentious issues aside. Tehran does not disguise the fact that its efforts to promote greater cooperation with the Gulf states have the ultimate aim of excluding extemal powers from the region. Iran, in doing so, has nevertheless "played down differences, shown flexibility and pragmatism about form, eschewed any temptation to lay down preconditions and has been phlegmatic about the speed with which an appropriate grouping can be created." 52

The "soft" side of Iranian strategy is not its willingness to risk confrontation, however. Iran took a decidedly threatening posture over $\mathrm{Abu}$ Musa, and has essentially refuscd tonegotiate at all on the issue. It also openly sided with Qatar in Qatar's dispute with Saudi Arabia. This was perhaps a charm offensive towards Qatar, but a distinctly confrontational one with the Saudis. The Iranian diplomatic offensive is not entirely peaceable, and there is a threat-sometimes unspoken but sometimes explicit-as well.

These important exceptions aside, Iranian diplomacy is intended to convey the following message: the Gulf states should not fear Iran's strength; Iran, in tum, should not concem itself with the GCC's foreign links. Neither a state's foreign alignment nor its ruling system should become an obstacle to regional cooperation. The longer-term Iranian goal, of course, is to promote regional cooperation as a way of excluding external powers that might challenge, offset, or complicate Iran's primacy in the Gulf. Iran sees the more visible presence of Westem (primarily American) forces in the Persian Gulf, and the close strategic relationship between the United States and Kuwait after the Gulf War, as a long-term threat to Iranian national interests, territorial integrity, and the security of the revolution. ${ }^{53}$ But the immediate action in the security field for Iran is to the north. Iran now has opportunities to expand its regional power by gaining influence with Azcrbaijan, Tadjikistan, and other former Soviet republics with large Islamic populations. At the same time, the breakup of the USSR holds out the prospect of instability and ethnic wars that could have serious spill-over effects. Under these circumstances, Tehran's policy rationale of avoiding conflict with outside powers will be even stronger. ${ }^{54}$

The second element in the Iranian national security strategy-deterrence-consists of a measured military buildup designed to impose high costs on an attacker (and cast a regional shadow) without provoking preemptive external military intervention. This buildup, discussed more fully in the following chapter, includes ballistic missiles and weapons of mass destruction. Fortunately for Iran, the defeat of Iraq in the second Gulf War reduced the amount of resources that Iran will have to devote to reduce its military imbalance with Iraq; however, Tehran believes that the Iraqi army still represents a formidable threat that Iran's ground forces cannot presently match. The ongoing purchases of former Soviet military hardware add credibility to the deterrent force, and provide limited offensive options.

The third element in the Iranian national security strategy-covert political action-is designed to further Tehran's larger ambitions, while at the same time avoiding Saddam's mistake of provoking the international community through overt military aggression. This includes support of revolutionary factions in areas such as the Sudan, Lebanon, and Algeria; support of terrorism and assassination; and continued opposition to the Arab-Israeli peace talks. Iran has shifted much of its effort from Lebanon to Sudan, which is becoming the new training ground for Islamic revolutionaries, some of them trained by Iranian Revolutionary Guards Corps trainers. It is also funding and arming the Sudanese campaign against Christians and animists in the south, and supporting the imposition of Islamic law in southem Sudan. Through Sudan, Iran is supporting the antiregime movements in Egypt, Tunisia, Algeria, and probably some of the Gulf Arab states. ${ }^{\text {ss }}$ Further, the assassination of Shahpur Bakhtiar in Paris dem- 
onstrated that the notion that Iran was refraining from such actions in order to cultivate European trade was mistaken.

This hard side to Iranian strategy has an important domestic component: it appeals to ideologues who still have considerable influence in the Iranian leadership, and who equate Islamic interests (defined as revolutionary Islamic interests aimed at toppling sccular regimes) with Iranian national interests.

Iran's assessment of thresholds. A critical question for future American policy in the region concerns Iran's assessment of U.S. thresholds for military intervention, given the experience of both the first and second Gulf Wars. Although there is no hard evidence on this score, the following would seem to be a reasonable extrapolation of Tehran's views. ${ }^{36}$

First, Iran probably believes that the circumstances leading to Desert Storm were unique and atypical, and that future regional conflicts are more likely to resemble the first war than the second. The Iranians probably feel that Saddam's invasion of Kuwait was blatant, unprovoked, and directly threatening to Westem interests. (By contrast, the 1980-88 Gulf War did not directly threaten Westem interests until the mining of the Gulf began to interfere with intemational tanker traffic in 1987.)

Second, Saddam could have gotten much of what he wanted without (unnecessarily) provoking the West. Iran, by contrast, faced no serious response to its full annexation of Abu Musa in 1992. The lesson would appear to be that Saddam was too greedy. Had he contented himself with occupying the Rumaila oil field and Warba and Bubiyan islands, he might have avoided a war: the United States would not intervene over a simple border dispute. By taking all of Kuwait, Saddam overstepped the line. Iran would be more likely to limit its provocation and thus limit the degree of Western response.

Third, Saddam had no effective fifth column inside Kuwait. The Iraqis tried without success to find well-known Kuwaiti opposition figures who would support their occupation. Their initial efforts to set up a Kuwaiti revolutionary government foundered. By contrast, Iran would seek to come to the support of an existing Shi'ite community in Iraq, Bahrain, or Saudi Arabiathus veiling their intervention as support of an oppressed community (an oppressed majority in some cases). This would be less blatantly aggressive, and might not provoke the same Westcm response.

Fourth, the United States under George Bush may have been unusually willing to intervene. Iran remembers clearly the humiliation of the United States over the hostage issue during the Carter administration. It could very well conclude that the Clinton administration may be a clone of the Carter administration. Many senior Iranian officials today know Warren Christopher's work well from that period. This could, of course, be a misjudgment on the part of the Iranians, but it is not an unlikely conclusion for them to reach.

Given these hypothetical lessons, Iran may therefore conclude that a Clinton administration will be less interventionist than Reagan-Bush. For one thing, Tehran may believe that it would be impossible for the U.N. coalition that confronted Iraq to ever be reestablished. To some extent, the coalition could only have occurred in the exact historical moment that it did. An increasingly nationalistic Russia that may be on the verge of full or partial disintegration, growing Islamic troubles in Egypt, and other developments have altered the particular mosaic that existed in 1990-91. Although many of the Arab states that joined the coalition against Iraq might also coalesce against Iran, Syria probably would not, and it is far from certain that the French and other Europeans would be as willing to participate. Also, the United States is dealing with brushfires elsewhere as well. With U.S. forces committed to Somalia and possibly involved in a future Balkan crisis, and with American forces in Europe drawn down from what they were in 1990, another Operation Desert Storm on the same scale might seem to the Iranians to be more difficult today.

Finally, the route to increasing Iranian influcnce on the Arab side of the Gulf may be through apparent domestic conflict in a GCC state followed by Iranian intervention, with the assumption that the United States is less likely to 
intervene in what begins as an internal upheaval. Iranian efforts in Iraq, Bahrain, or even the Eastem Province of Saudi Arabia could begin as such an internal revolt, to be followed by Iran intervening to "protect" a revolutionary government against counterattacks. This would at least creatc a certain ambiguity for Westem interventionists.

\section{The Response of Potential "Victim" States or Factions}

This section examines the responses of states or factions that are fearful of aggression, whether originating outside or inside their territory, and that wish to encourage international military intervention as a means of deterring or dealing with that aggression. The Gulf War was a graphic demonstration to weaker states and factions of their potential to become victims in the post-Cold War era. Some states, such as Saudi Arabia, had previously tended to assume that such direct aggression was unlikely-that traditional political and economic means to reassure, buy off, or balance potential regional adversaries would still be effective. The Iraqi invasion of Kuwait, which, in Saudi eyes, nearly became an assault on their own territory, dispelled the notion that security could be maintained largely through nonmilitary instruments and by local means.

In the end, Saudi Arabia, because of its intrinsic importance, concluded that it could rely on the military guarantee of the only superpower, the United States-although it still wants the American presence to stay over the horizon. Most other states with the potential to become "victims" do not think that they can rely on Washington alone. Even a statc like Singapore, which has sought to strengthen its ties with the United States since the war and which has no great-power altemative to American protection, is dubious that the United States will intervene whenever or wherever a small state should become the victim of aggression. It therefore favors strengthening U.N. security mechanisms that deal with the maintenance of international peace and security. ${ }^{57}$
In the case of Taiwan, the Gulf War held conflicting lessons about the attitude of the international community. On the one hand, one of the casus belli given by the coalition forces for the Gulf War was the determination that aggression would not stand in the New World Order. This could be a welcome precedent for the Taiwan concemed about potential attack from the PRC. On the other hand, Taiwanese security spccialists realistically assessed that a common vital interest in oil was also a driving factor for the United States and many of its partncrs in the Gulf. The Taiwanese government is hence not sanguine about the world community seeing a similar vital reason for coming to Taiwan's defense. This professed lack of confidence in international intervention, it should be noted, is held by the goveming party; this official pessimism may be designed to counter the views of the opposition, which could argue that the lesson of the Gulf War is that Taiwan can declare independence and expect American support should the PRC try militarily to oppose the declaration. ${ }^{58}$

How confident can smaller states, or factions within states, be of international mechanisms to maintain their security? The Gulf War initially created the belief that the international community might automatically intervene to protect "innocent victims" of aggression (i.e., a New World Order existed in fact as well as in rhetoric). In the early stages of the Yugoslav crisis in 1991, Croatia tried to adopt an "innocent victim" posture to prompt international armed intervention on its behalf; official Croatian representatives made frequent public efforts to link Croatia's situation with that of Kuwait. ${ }^{59}$ Serbian President Milosevic was characterized as "the Saddam Hussein of the Balkans." The actions of the Security Council to protect the Kurds was seen as a precedent for Croatia's appeal to the international community. The importance of taking the Yugoslav issue to the Security Council (in contrast to the European Community) was that it required the involvement of the United States. One Croatian commentator wrote: "What God wants, without Bush, will not be . . . if nothing else, America cannot lose the initiative from the Gulf War." 
The Croatian government thus emphasized a strategy of military passivity to highlight the aggressor-victim distinction; the government's initial strategy was for its forces to do as little as possible and defend only where necessary. In some cases, those who took the military initiative at local levels were criticized and refused support by the Zagreb government (e.g., the defendersof Vukovar). Defense MinisterSpeglj, who argued for better preparations and a more active defense, was forced to resign in August 1991. To be sure, given the Croats' military inferiority, it is also plausible that Zagreb's attempts to exploit Croatia's helpless victim status to invoke international intervention was mercly an attempt to make a virtue of necessity. Croatia changed this strategy in October 1991 and ordered full mobilization, possibly because it had become clear by that time that international intervention would not be forthcoming. There may have been a subsequent change in Croatian strategy, which involved Zagreb's increasingly aggressive participation in the partition of Bosnia-Herzegovina. This change was based on the Croats' growing awareness that there would be no outside intervention to stop either the Serbs or the Croats from presenting the world with a fait accompli against thcir neighbors. ${ }^{61}$

The Bosnian govermment has followed a similar path of nonpreparation for war while calling for international intervention-and while making clear and overt references to the Gulf War. ${ }^{62}$ (As with Croatia, it is not clear how much this is a calculated "innocent victim" strategy, as opposed to sheer necessity.) Bosnian Foreign Minister Silajdzic has argucd that: "The United Nations can provide the umbrella for such an operation just like the one we had in the Gulf." Bosnian strategy also encouraged intervention for humanitarian purposes (as was done for the Kurds). A government advisor reportedly said, "Let Bush come with humanitarian aid, take control of the roads, get his troops or helicopters shot at ... and pretty soon he'll find he's fighting the same war as us." It is also possible to argue that the Bosnian govemment operated on the assumption that the international community could be induced and even provoked to intervene militarily, and to this end were even willing to inflict grave injurics ("atrocities") on their "own" people, in Sarajevo and elsewhere, that they believed could be blamed on the Serbs. ${ }^{63}$ Unfortunately, the Bosnians have come to understand that the world is not working this way. Ganic, deputy to the Bosnian president, in comparing Bosnia with Kuwait, arrived at the following formulation: "If you are a small country without oil, without strategic resources, the world only sends you messages like 'stay brave."'

By contrast, official Slovenian assessments of the Gulf War in early 1991, which were part of a more comprehensive study of the international community undertaken as they formed their strategy for independence, led to the conclusion that, unless there was an overriding material reason for international intervention, an "innocent victim" strategy would not suffice. Slovenia's defense preparations accordingly were consistent with the territorial defense doctrine of the old Yugoslavia (Doctrine of General People's Defense)-i.e., defend in order to mobilize intemational support. Slovenia assumed that it did not intrinsically present an immediate and obvious interest to the international community, but that effective military resistance on its part might generate intermational support. Slovene assessments of their ten-day war with the YPA tended to confirm that their strategy was essentially based on their (correct) calculation that neither the YPA nor Milosevic (who had al ready written off Slovenia as a nuisance not worth keeping) would attempt to keep Slovenia in Yugoslavia if they encountered serious resistance. ${ }^{64}$

The Gulf War also pointed to the importance of good media relations - the Slovenians established a modem media center on the eve of their declaration of independence, and provided efficient, regular briefings on the state of events.

The Kosovo Albanian leadership, also having concluded that events in their region do not represent an immediate and obvious international interest, scems to have ruled out a futile uprising in hopes of being able to present themselves as victims. (That said, given continuing provocation, there is no assurance that the current or future leadership in Kosovo might not 
succumbto pressure and abandon their "Ghandi" approach in favor of an uprising.) Some Albanian representatives have stressed the importance of mineral resources in Kosovo; however, it is unlikely that they think that such resources are anything like oil in importance to the international community.

Some states, especially those that believe they might possess intrinsic importance to external powers, likewise took away from the Gulf War the lesson that they need to develop military capabilities sufficient to delay an aggressor long enough for international - or American-intervention to take effect. As one Singaporean member of Parliament stated, "If Kuwait had been better prepared and managed to keep the Iraqi troops at bay for some time, other countries could have come to its assistance." 65 Examples of such states include Saudi Arabia, Jordan, Singapore, and Taiwan. The lesson for such states from the experience of Kuwait is that the lack of any effective defensive military capability invites aggression. A fait accompli by an aggressor puts the onus on external powers: do they want to go to the trouble and expense of reversing the aggression? Even if the answer is yes, do potential "victim" states really want to go through the pain of liberation?

The likelihood of successful international intervention is thought to be increased if the "victim" can delay and complicate the aggressor. Perhaps the most common military solution designed to impose such delays/complications involves the development of air power. In the Saudi case, it also means a sizable expansion in the ground forces.

\section{Conclusion: Military Power Still Matters}

The Gulf War undermined the case that a new hierarchy of powers would emerge in which military capability would be significantly devalued, and that status and influence in the international system would be based to a first order on economic competitiveness. "Trading states" such as Germany and Japan, which had appeared to be the wave of the future, now seemed to be limited and one-dimensional given their performance during the Gulf. This is not to say that economic power doesn't mattermost states assume that it will be of increased significance in the post-Cold War era-but the Gulf Warled to a more balanced appraisal of the relative importance of military power and other national attributes. Military capabilities still matter in relations among the major powers because of the implications and dangers of regional conflicts, even if the potential for strategic conflict among the major powers has essentially disappeared.

The Gulf War also represented a critical step in the establishment of precedent for international intervention in the emerging strategic environment. During the Cold War, the conditions and mechanisms for such external intervention in regional conflict were conditioned profoundly by the East-West conflict; overtime, well-established and understood rules of the road emerged as to what organizations could be used under what circumstances and for what ends. This is all up in the air with the end of the Cold War - the Gulf War, and now Yugoslavia and Somalia, are critical data points for establishing new sets of legitimate mechanisms and rules for the use of force in local and regional conflicts.

All states-external powers, victims, and aggressors-learned somcthing from the Gulf War, and are now learning from Yugoslavia, about what those mechanisms and rules might be. More importantly, they are currently-in Yugoslavia and elsewhere-trying to influence the setting of future precedent for regional intervention based on what they learned in part from the Gulf. For India, the greatest lesson of the Gulf War was the imperative to avoid invasion of another sovereign state. Yugoslavia highlights the gray areas that make such a formulation difficult to apply in practice-are the current Balkan conflicts aggression or civil war? Indians often refer to the Kashmir analogy when discussing the Bosnian case, wondering what rules the international community will ultimately apply to both circumstances. ${ }^{66}$ 
That said, the Yugoslavian crises do not void the lesson of the Gulf about the importance of military power in future regional conflicts, as some have argued. Yugoslavia adds another data point, but it in its own way is as unique as the Gulf War. Regional experts on East Asia and the Middle East assess the conflicts in the former Yugoslavia to have a negligible effect on Gulf War lessons learncd. For Chinese leaders, for example, Yugoslavia is a reminder of consequences of the weakening of central political authority in a communist state - but it does not in and of itself profoundly change the point that military power remains a critical element in comprehensive national sccurity. ${ }^{67}$

\section{Endnotes}

1. The new Malaysian Five Year Plan (199195) was announced in July 1991, prior to the Iraqi invasion of Kuwait. Ishtiaq Hossain, "The Gulf War Lessons Leamed by Foreign Nations: A Case Study of ASEAN States and Vietnam," unpublished paper written for the CNSS Foreign Gulf War Lessons Leamed Study, March 1992, p. 28.

2. Pierre Joxe, "Defensc et renseignement," Defense Nationale (July 1991), p. 12, cited by David Yost, "France and the Persian Gulf War: Political-Military Lessons Learned," unpublished paper written for the CNSS Foreign Gulf War Lessons Learned Study, May 1992, p. 21.

3. Joxe speech at the Centre des Hautes Études de l'Armement, Septcmber 10, 1991, SIRPA Actualité no. 30, Scptember 13, 1991, pp. 4-5, cited in ibid.

4. In the judgment of one Asian security specialist: "There is no rcason to doubt that the Vietnamese leadership was impressed with the superiornature of American-made weapons used in the Kuwaiti war. In particular, the leadership was amazed with the relative ease with which the Americans destroyed the Soviet-built Iraqi air defense system. However, I do not believe that they will agree that a war like the one against Iraq would have succeeded against them. The Vietnamese leadership points out that the topography of the region was one major contributory factor in the success of the Americans in the Kuwaiti war. In other words, the Iraqi forces were sitting ducks on flat lands. Hanoi's leadership does understand, rather grudgingly, that although they won the war against the Americans, they have been defeated in victory. Therefore, it would be political suicide for the Vietnamese to acknowledge in public that the military victory of the Americans in Kuwait was because of their superior weapon systems. On the contrary, the leadership gleefully points out that they won their war in Vietnam despite the superior nature of the American weapons then existing." Written comments by Ishtiaq Hossain, National University of Singapore, September 16, 1992.

5. Ephraim Kam, "Gulf WarLessons Learned by Egypt," unpublished paper written for the CNSS Foreign Gulf War Lessons Learned Study, March 1992, p. 18.

6. Obviously, the United States did require some support from other nations, most notably Saudi Arabia, but there was no overriding imperative to use the United Nations.

7. This section was developed with the assistance of Charles Ball of the CNSS staff.

8. T. Enders and M. J. Inacker, "The Second Gulf War and Germany: Contributions and Political and Military Lessons," unpublished paper written for the CNSS Foreign Gulf War Lessons Learncd Study, October 1991, p. 49.

9. Pierre Joxe, speech to the Assembly of the WEU, June 4, 1991, p. 8 of text provided by the Ministry of Defense, cited in Yost, "France and the Persian Gulf War," p. 22.

10. Francois Heisbourg, "Premieres leçons militaires pour la France," Liberation, 19 February 1991, cited in ibid., p. 68.

11. Francois Heisbourg, "Quelles leçons stratégiques de la guerre du Golfe?" Politique Étrangère 56 (Summer 1991): 415 , cited in ibid., p. 25 .. 
12. David Earling, "Italy and the Gulf War," unpublished paper written for the CNSS Foreign Gulf War Lessons Learned Study, September 1991, p. 43.

13. These quotations are taken from Luis $\mathbf{M}$. Villanueva, "Spain: The Gulf War Lessons," unpublished paper written for the CNSS Foreign Gulf War Lessons Learned Study, November 1991, pp. 13, 17.

14. Ibid., p. 10. For example, Italian Army General Lucio Inneco wrote that "the international stature of a country [will be] measured by its level of participation in moments of intemational crisis, and not by its declarations alone." C.A. Lucio Innecco, "Ammaestramenti in Materia di Sicurezza dall' Esperienzadel golfo," RivistaMilitare (May-June 1991),p. 31, cited inibid.,p. 43.

15. Joseph Nye, "Coping with Japan," Foreign Policy 98 (Winter 1992/93): 112.

16. Interview with Europcan security expert, Los Alamos, NM, May 1993.

17. Enders and Inacker, "The Second Gulf War and Germany," p. 44. Former Defense MinisterStoltenberg and General Inspecteur Naumann have publicly recommended the establishment of a national command structure (Fuhrungskommando Bundeswehr); this is widely perceived as reestablishing a German General Staff.

18. The following discussion of Japan is largely drawn from Mike Mochizuki, "Japan and the Persian Gulf Crisis: The Lessons Learned," unpublished paper written for the CNSS Foreign Gulf War Lessons Learned Study, January 1992. The information was updated by Mochizuki in a December 1992 telephone interview, and supplemented by a CNSS-sponsored workshopon Japanese Gulf War lessons learned, held in Washington, DC, on December 12, 1992.

19. Some specialists at the December 1992 workshop argued that events during the aftermath of the Gulf War may have been more important than the war itself in influencing Japanese perspective on security. These events included the cancellation of
President Bush's planned trip to Japan, and then the difficult outcome of that visit when it did occur in January 1992.

20. The Japanese mainstream refers to those who have tended to support a basic proAmerican foreign policy orientation and usually come from the following circles: (1) the Ministry of Foreign Affairs and the Defense Agency; (2) the leadership and most of the backbench politicians of the ruling Liberal Democratic Party; and (3) conservative think tanks. Mochizuki, "Japan and the Persian Gulf Crisis," p. 3.

21. For example, Saburo Okita, former Japanese Foreign Minister, has commented on "China's drive to boost its own military spending and naval capability - a drive fueled largely by Desert Storm's impressive display of military technology." See his prepared remarks at the University of Scranton (Pennsylvania), September 14, 1992, p. 5.

22. Interview with Japanese security expert, Cambridge Massachusets, September 1992. See also "The 'Secret' Mission of the Minesweepers," Mainichi Shimbun, November 6, 1991, moming edition, p. 3, in FBISEAS-91-220-A (November 14, 1991), pp. 6-7.

23. S. Javed Maswood, "Japan and the Gulf War," Pacific Review 5 (no. 2): 150.

24. Dean Cheng, "A Report on East Asian and Naval Lessons from the Gulf War," unpublished paper written for the CNSS Foreign Gulf War Lessons Learned Study, February 1993, pp. 5-6.

25. Robert L. Butterworth, editor, Guide to Space Issues for the 1990s (Los Alamos, NM: Center for National Security Studies, Los Alamos National Laboratory, December 1992), pp. 86-87.

26. Cheng, "A Report on East Asian and Naval Lessons from the Gulf War," p. 6.

27. Those holding "pacifist" views in Japan come from the majority of the Japanese scholarly community, and many of them have close links with the Japanese Socialist Party. 
28. Yoichi Funabashi, "Japan and the New World Order," Foreign Affairs 70 (Winter 1991/92): 65-67.

29. Ibid.

30. Masaru Tamamoto, "Trial of an Ideal: Japan's Debate over the Gulf Crisis," World Policy Journal 8 (Winter 1990-91): 104-5.

31. Written comments provided by Gregg Rubinstein, April 1993.

32. George Joffe, "Libyan Reactions to the Conflict in the Gulf," unpublished paper written for the CNSS Foreign Gulf War Lessons Learned Study, July 1991, pp. 4-6.

33. Gerrit W. Gong, Lessons Learned from the Persian Gulf War: Asian Perspectives, CNSS Briefing, vol. 3, no. 9 (Los Alamos, NM: Center for National Security Studies, August 1992), p. 5.

34. Juan del Aguila, "Cuba's Views of the Gulf War and Its Aftermath," unpublished paper written for the CNSS Foreign Gulf War Lessons Learned Study, February 1992, pp. 2-3.

35. Interview with Middle East expert, New York City, September 1992.

36. del Aguila, "Cuba's Views of the Gulf War," p. 14.

37. Cited in ibid., p. 15.

38. Joffe, "Libyan Reactions to the Conflict in the Gulf," p. 14.

39. See Robert W. Swartz, Lessons Learned from the Persian Gulf War: Middle East Perspectives, CNSS Briefing, vol. 8, no. 3 (Los Alamos, NM: Center for National Security Studies, July 1992), p. 7.

40. Telephone interview with South Asian security specialist, February 10, 1993.

41. Interview with Middle East analyst, New York City, September 1992.

42. Interview with Taha Yasin Ramadan, Amman AL-WATAN, May 17, 1992, in FBIS-NES, May 26, 1992, p. 14.

43. Interview with Tariq 'Aziz conducted by Khayri Mansur, Amman AL-DUSTUR, February 19, 1992, in FBIS-NES, February 28, 1992, p. 29.

44. Barzan al-Tikriti, "Some Causes of the Collapse of the Soviet Union, Baghdad
$B A B I L$, January 13, 1992, in FBIS-NES, January 31, 1992, pp. 37-46.

45. Ahmed Hashim, Resurgent Iran: New Defense Thinking and Growing Military $\mathrm{Ca}$ pabilities, paper prepared for the American Association for the Advancement of Science, August 1992, p. 24.

46. (Clandestine) Voice of the Iraqi People, in FBIS-NES, March 25, 1992, p. 18.

47. This section is based substantially on James Gow, "Yugoslavia and Lessons from the Gulf War," unpublished paper written for the CNSS Foreign Gulf War Lessons Learned Study, October 1992.

48. These quotes are from articles in Vojno Delo 18, nos. 4-5, July-October 1991, cited in Gow, "Yugoslavia and Lessons from the Gulf War."

49. Written comments provided by Dennison Rusinow, December 1992.

50. Telephone interview with European military expert, June 1993.

51. This section is built substantially on Shahram Chubin, "Iran and the Lessons of the Gulf War 1991," unpublished paper written for CNSS Foreign Gulf War Lessons Learned Study, November 1991.

52. Shahram Chubin, "Iran and Regional Security in the Persian Gulf," Survival 34 (Autumn 1992): 73.

53. Hashim, Resurgent Iran, p. 17.

54. This section draws from Chubin, "Iran and Regional Security in the Persian Gulf," pp. 62-80.

55. Written comments provided by Michael Dunn, January 1993.

56. Ibid.

57. Hossain,"Vietnam and the ASEANStates," pp. 6-9.

58. See Jaushieh Joseph Wu, "The Lessons of the Gulf War: The Perspective of the Republic of China," unpublished paper written for the CNSS Foreign Gulf War Lessons Learned Study, October 1991; and Peter Kien-hong Yu, Richard H. Yang, and Andrew N. Yang, "The 1990/91 Persian Gulf War Lessons: A Chinese View from Taiwan," unpublished paper written for the 
CNSS Foreign Gulf War Lessons Leamed Study, October 1991.

59. The following discussion of Croatia, Bosnia, Slovenia, and Kosovo is taken from Gow, "Yugoslavia and Lessons from the Gulf War," pp. 25-30.

60. Gow acknowledges that "a review of the principal newspapers in Croatia for the period from June to October suggests that associations of this kind were not necessarily a primary issue intemally. It is possible that as far as such comparisons were made, they may have been made by Western journalists first and then taken on board by the Croats." "Yugoslavia and Lessons from the Gulf War," p. 27.

61. Written comments provided by Dennison Rusinow, December 1992.
62. The following discussion is taken from Gow, "Yugoslavia and Lessons from the Gulf War," pp. 28-29.

63. Written comments provided by Dennison Rusinow, December 1992.

64. Written comments provided by Dennison Rusinow, December 1992.

65. The Straits Times, August 19, 1990. Singapore's then Minister of Information and Communications remarked that "the fastest way to make enemies and invite invasion was to generate wealth and ignore defense." Ibid.

66. Telephone interview with specialist on South Asian security, February 10, 1993.

67. Intervicw with specialist on Chinese security policy, Washington, DC, September 1992. 


\section{Chapter Three: Technology Matters}

Operation Desert Storm demonstrated to foreign observers the advent of a new type of modem warfare characterized by the integrated employment of advanced military technologiesin terms of weapons, supporting infrastructure, and management of the crisis/battle. This demonstration forced a general reevaluation of national military capability and competence for many nations, great and small.

This is not to say that technology was scen as the sole reason for the coalition's victory; foreign militaries recognized that American forces, in particular, were well-led and well-trained, and had devcloped superior doctrine and operational concepts. At the same time, many-but not all-foreign experts are of the view that the Gulf War was the first significant display of a variety of technologies that have the potential to dominate warfare over the next several decades. As a consequence of this assessment, the Gulf War has reccived a good deal of attention from foreign militarics, even if they believe that the circumstances of the war were unique or not directly applicable to their own situation.

Prior to the Gulf War, there was considerable skepticism about how well new technologies such as stealth would perform in conditions of actual combat. Westem critics of advanced military technology claimed that these systems were too complex and fragile for use on the battlefield. Devotees of people's war concepts in the Third World pointed to the image of Victnam and Afghanistan, which suggested that the military forces of the major powers, even with (or because of) their reliance on advanced technologies, could be stalemated by a serious and determined Third World adversary.
The Gulf War has by no means eliminated all doubts about the efficacy of advanced technologies. Theodore Postol has produced a widely publicized critique of the performance of the Patriot; questions have been raised whether coalition forces destroyed any SCUDs on the ground; and there has been a lowering of official judgments of the performance of precisionguided munitions (PGMs) and submarinelaunched cruise missiles (SLCMs). Some revisionist interpretations are beginning to emerge in the Middle East, and elsewhere, to the effect that the Iraqi performance was so inept as to provide little real test of these technologies. This said, as with the case of the performance of the American military more broadly, foreign militaries still tend to focus much more on the successes rather than the failures of advanced technologies - and much mone on their potential than their limitations. (There are interesting and important exceptions to this generalization, discussed below.)

This chapter examines the view of foreign militaries about why (and which) technologies mattered. It provides highlights of foreign military-technical assessments of Operation Desert Storm; evaluates foreign views of the meaning of the Gulf War for the future character of warfare, including whether the Gulf signaled a revolution in military affairs; and considers how a selection of foreign militaries - those of the Westem industrial democracies, important regional powers, and potentially hostile statesare (or are not) adjusting their military doctrine, force structure, and investment strategy to account for the lessons of the Gulf War. 


\section{Highlights of Foreign Military Reactions to the Gulf War}

Any evaluation of foreign lessons lcamed from the Gulf War must take into account several key points. Most importantly, forcign military assessments of the Gulf War must be viewed in the context of their particular national circumstances. For example, Gulf War "lessons learned" frequently become ammunition for use by one or both sides in an internal dcbate about future mili ary doctrine and force structure, and must be understood as such.

Second, in many cases, foreign militaries lack the resources to undertake a full-scale analysis of the Gulf War, they will thus tend to draw heavily from others' reactions, particulariy Americ n. This creates an obvious problem of mirror-1magi.ng for U.S. analysts studying foreign reactior is to the Gulf War. Some forcign militaries may reflect back to us what we ourselves think, perhaps iwrongly confirming some of our own misperceptions of the Gulf War. This also suggests that some forcign militaries, aware that we are :ollowing them as they assess the Gulf, may attempt to tailor thcir reactions to the war so as to influence U.S. thinking along desirable 'ines. In other words, we cannot rule cut apparent foreign lessons learned as being a conduit for deception and disinformation.

Third, most states do not regard the American style of war, as demonstrated in the Gulf, as something which they will attempt to emulate or oppose. This fact limits somewhat the salience of Gulf War lessons learned for foreign militaries. Operation Desert Storm is regarded, for a variety of reasons, as a uniquely Americ. 1 phenomenon. Foreign militaries may pursue certain technologies, capabilities, or concepts that were demonstrated in the Gulf, but we should not measure their reactions to the Gulf by the same yardstick as we evaluate ourselves.

Finally, with a few important exceptions (e.g., North Korea), even those states that are potentially hostile to Washington do not focus their military planning or force structure development on a war with the United States. This includes raq, which has been and remains concerned primarily with internal control or re- gional opponents. These states do not ignore the possibility of conflict with the United States or other advanced military powers, but we should noc fall into the trap of assuming that they routinely put themselves in Iraqi shoes and are busily planning to counter a future Desert Storm.

This is not to say, however, that the lessons of the Gulf War went unheeded by foreign militaries. The Taiwanese military, for example, undertook its own extensive analyses of the war, and also arranged for a high-ranking American delegation, led by retired U.S. Army Chief of Staff General Carl E. Vuono, to conduct a special two-week briefing and teaching seminar on the war. The Taiwanese focused on three issues: (1) the lessons that the People's Republic of China derived from the war, (2) critical technologies, especially those that yielded the highest payoff for defensive and counter-offensive operations; and (3) the $C^{3}$ I systems used by the United States to conduct its own operations as well as to control the operations of the entire coalition. ${ }^{1}$

What follows is not an attempt to summarize each and every foreign military perspective of the Gulf War, but rather an effort to provide a generalized assessment and to highlight some of the most salient and interesting judgments, especially as they relate to technology.

\section{Military-Technical Evaluation of the Coalition's Performance}

Any assessment of Gulf War lessons learned must take into account the expectations that most foreign political and military leaders held going into the conflict. For the most part, these leaders-especially those in the Third Worldbelieved on balance that the coalition would win if ccinflict occurred, but the war would not end swifuly and coalition casualties would be substantial. ${ }^{2}$ Some states, including China, thought that Iraq might actually win, in the sense of forcing the coalition to abandon its military campaign because of the costs involved.

The Iranian prewar view is quite interesting because Iran had just concluded a war with Baghdad. Iraq's defeat was expected by Tehran, 
given Iraq's preference for static defensive operations, its inadequate air-power, air-defense and intelligence, and its exaggerated view of the importance of ground forces. But Iranian specialists believed that "the war will be extensive and prolonged." The United States held the trump card of the most modern technology and weaponry, but allied victory would not be possible without sustaining heavy casualties. ${ }^{3}$

The war was a particularly sobering experience for those states that had based their own planning on the expectation that a Vietnam-like stalemate could be imposed on the American military, and that the human factor in warfare could offset superior technology. These states had expected that Iraq could give a reasonable account of itself, particularly by imposing severe casualties on the American invaders. For example, prior to Operation Desert Storm, Cuban President Castro quoted a "wise American leader" to the effect that "a day of war would be costlier than a year of peace," and he later argued that "the Iraqis may have the means to guarantee a relatively long resistance [which] would not be ideal for the Yankees." Vice President Carlos Rodriguez asserted that "Iraq is ready to immolate its population and blow up its own oil installations, leading to chaos in the American economy." As late as February 1991. the Cuban press carried an article opining that "the air war would not be sufficient to defeat Iraq, and a ground war would increase [U.S.] casualties geometrically," citing reports from USA Today that 65,000 American soldiers would die. $^{4}$

The view that Operation Desert Storm would be a lengthy and difficult war was by no means confined to the anti-Western powers. For example, it was reported in the Brazilian press that Brazil's General Staff estimated the minimum duration for the war at six months, with allied casualties in the tens of thousands. Retired Brazilian army officers argued that this was a best-case assessment; military operations against Iraq would be many times worse than Vietnam. A few other Brazilian experts anticipated a few weeks of intense war with extensive military and civilian casualties on both sides, and with coalition air raids being answered with terrorist attacks. In the Brazilian public discussion and debate about the war, it was generally expected that the American war effort against Iraq would require at least a million men, and that a high level of casualties would prevent the United States from maintaining its forces in the field. There was, however, no consensus on exactly where the American breaking point was. It was also commonly held that the United States would use nuclear weapons. ${ }^{5}$

In light of these prewar assessments, the general reaction among foreign militaries to the coalition's performance ranged from "surprised" to "stunned." The less contact that foreign militaries had had with the United States prior to Desert Storm, the more unexpected was the degree of the Amcrican success. Again, the surprise was not simply that the coalition won, but that the war ended so quickly and with so few casualties. More than a few observers noted that even the U.S. military seemed surprised at so favorable an cuscome. At another level, foreign militaries were not surprised that technology played a major role-but as a rule they didnotexpect that advanced technologies would prove to be so effective and that they would play such a dominant role.

Most foreign military assessments did note the unique or unusual circumstances of the Gulf War that favored the coalition. The Vietnarnese leadership, although amazed by the relative ease with which the Americans destroyed the Sovietbuilt Iraqi air defense system, pointed out that the topography of the region was one of the major contributory factors in the American success. ${ }^{6}$ The Serbian military also noted the favorable desert terrain, the six months of uninterrupted time to build-up forces in the theater, and the passivity of the Iraqi defenses. In the Serbians' view, the war was virtually won in the period of preparation. ${ }^{7}$ But most foreign assessments tended not to dwell on the limitations to American military power that these circumstances might have implied, but rather on the inherent capabilities and advantages possessed by advanced military forces.

Foreign observers tended to focus on the following enabling capabilities that set the United States apart as a global military superpower and 
Underpinned its ability to wage a unique form of high-technology, high-intensity warfare.

- Logistics. The ability to move very large forces over long distances and sustain those forces for a substantial period of time.

- Information nuanagement. The ability to collect, integrate, and distribute strategic, operational, and tactical intelligence; the ability to communicate from and to all levels; and the ability to deny these capabilities to an adversary. This involved not only control over information by the military but, in the minds of many states, the manipulation of the Western media to the U.S. advantage. $^{8}$

- Combined arms and joint operations. The ability to conduct an integrated, not just an orchestrated, military campaign, involving different service branches as well as oiher national forces.

In the words of Dan Shomron, the Israeli Defense Force's Chief of Staff during the war: "The United States is prosecuting the war precisely in the areas where it has relative advantages, and from a stratcgic perspective that is very correct. They are opcrating precisely in the realm in which they possess relative superiority as a great power."

In the view of the vast majority of foreign observers, air power detcrmined the outcome of the war, although aviation is not all powerful. Air power executed or contributed to all the significant tasks of the war: it disrupted the enemy's command and control, destroyed the air defense system, destroyed and demoralized the Iraqi air forces, damaged Iraqi economic potential, and created optimum conditions for the ground operations. The Italian air force (not surprisingly) hailed this as a solid confirmation of the strategic air doctrine of Giulio Douhet, which they characterized as a massive and continuous air campaign against all strategic targets from the front lines to the deep rear. ${ }^{10}$

Some foreign militaries saw the key to air operations as being the coordinated employment of the F-117A, the cruise missile, and defense suppression (EW, HARM) to break down coordinated Iraqi air defense capabilitics. Observers cited Operation Desert Storm as the first practical integrated employment of strategic and tactical aviation, and the first largescale use of stealth and cruise missiles. Perhaps the most surprising element of the air campaign for many foreign militaries-including the Iraqis-wasitsduration (approximatcly six weeks). Soviet estimates of the length of the campaign ranged from two to three days to two weeks at maximum; the Iraqi military, steeped in Soviet doctrine, had a similar view. ${ }^{11}$

The Israeli military stressed the virtual as well as direct effects of the air campaign-it allowed the coalition to put tremendous pressure on the Iraqis and their ability to sustain operations. The important factors here were the high sortie rate generated by the coalition air forces, coupled with the use of PGMs and electronic warfare. Although the Israelis were critical of the direct effectiveness of the air campaign against Iraqi SCUDs in westem Iraq, they did comment favorably on the campaign's virtual effects. Irrespective of how many missiles or transporters-erectors-launchers (TELs) were actually destroyed, the air of fensive reduced the tempo and accuracy of the Iraqi aitacks against Israel. ${ }^{12}$

The success of precision-guided weapons received a good deal of attention from nations such as Israel, which had already made a commitment to move in this direction prior to the war. The Israelis noted that this was the first time that any military had made such extensive use of these weapons and tested their performance in war. Still, caution is the order of the day. The Israeli Chief of Staff, Lt. General Ehud Barak, argued that: "In terms of target destruction, it seems to me that a couple of dozen per cent of the targets were hit. I couldn't say whether it was 25 or 35 per cent, but this is the result of the operation of a very small percentage of the sorties. In a sense, this war demonstrated the potential of these weapons more than it fulfilled [that potential]."13

The value of space systems in the conflict was emphasized most strongly by the French, Soviets/Russians, and the Israelis, among others. From the Soviet viewpoint, space assets played 
a significant role in the preparation and conduct of the campaign (reconnaissance, battle management, meteorological, and damage assessments). They also provided impressive support for the tactical user. The Italian military noted the utility of the Global Positioning System (GPS)_-"a true multiplier of forces that favored ground movements of the multinational troops, contributing to the rapid encirclement of the Republican Guard."14 It was noted that space systems provided warning and cueing for the Patriot antitactical ballistic missile system, and for the counter-air campaign. In fact, U.S. space systems were credited by the Soviets with real-time support for air operations. ${ }^{15}$

The use of space assets in the Gulf War reflected an even greater coalition dominance in battlefield surveillance, including such systems as AWACS, the newly available JSTARS aircraft, and unmanned aerial vehicles (UAVs). The German military noted that the principle of near-real-time tactical reconnaissance by UAV was proved during the war, and that UAVs will be even more valuable if future generations feature laser-designation and long-range data relay capabilities. ${ }^{16}$

Several foreign military assessments held that the Gulf War demonstrated that electronic warfare (EW) is no longer a combat support element, but rather can be fully integrated into operations and contribute directly to deciding the course and outcome of the war. EW was seen to be particularly crucial in the air campaign-perhapsevenmore important than stealth in accounting for the effectiveness and low loss rate of coalition aircraft. In the respective views of Indian and Italian writers:

While the first multinational forces air attacks wcre directed against Iraq's air defense capabilities through strikes against radar stations, SAM [surface-to-air missile] and low-level air defense artillery batteries, command and control systems, airfields, it was really the quantum advantage in Electronic Warfare capabilities that yielded decisive results. Electronic intelligence and countermeasure aircraft jammed and confused cvery type of electronic emis- sion used by the Iraqis and this rendered not just the air defense system but all forms of fire control effete [sic] and the territory naked. ${ }^{17}$

Electronic warfare technologies conditioned the planning and course of the entire battle and allowed coalition forces to act with relative impunity in their strikes on Iraqi positions. Despitc the fact that the Iraqis were alerted to the imminent air offensive, electronic warfare measures... allowed the coalition to defy standard concepts of "coefficients of attrition" for an alerted enemy, thus permitting deep strikes. ${ }^{18}$

Night fighting capabilities were regarded by foreign militaries as being highly important in attaining surprise and sustaining the initiative and 'momentum of the coalition's air and ground offensives. ${ }^{19}$ As Chinese military writers noted, the night had previously belonged to low-technology militaries, whereas it now is the province of the advanced military powers. The French, by contrast, found themselves limited by the fact that their participation in the coalition's air offensive could take place only during the daytime; France's Jaguar aircraft, unlike those of the British, had never been modemized with avionics and other equipment to make them capable of night and adverse weather operations. ${ }^{20}$

In terms of the ground campaign, the varied roles of helicopters were widely noted by the German and Egyptian militaries, among others. Italian specialists cited the unique use of helicopters as an "aerial cavalry" that established bridgeheads and strongholds behindenemy lines, creating logistical bases for the supply of munitions, fuel, and food. For the first time, the establishment of these points proceeded rather than followed the movements of the larger fighting units. ${ }^{21}$ Helicopters also proved invaluable as tank killers and for reconnaissance.

In addition to the advantages provided by advanced U.S. technologies, foreign observers from Italy, India, and South Korea, among other nations, cited the American command system as a crucial reason for the improvement in U.S. 
performance compared with that of the Vietnam conflict. ${ }^{22}$ The delegation of military decision making to the theater CINC by Washington, with the national command authority (NCA) providing general political guidance, was seen as a major factor in the coalition's victory. The Goldwater-Nichols reforms were said to have provided the Chairman of the Joint Chiefs of Staff with adequate operational responsibility, and to have permitted excellent coordination of the services in theater.

\section{Weaknesses in the Coalition's Performance}

As noted above, there was a widespread foreign appreciation of the advantages that the coalition enjoyed-in terms of the time available to mass forces, the relatively favorable desert terrain, a ready-made infrastructure in Saudi Arabia, and the like. Foreign observers accordingly concluded that the United States and its coalition partners might not have done as well had these conditions been less favorable. Potential shortcomings in U.S. fast strategic transport and logistics were particularly remarked upon. The inability to deploy sufficient forces in good time to stop a rapid armored assault-such as Saddam might have mounted against Saudi Arabia from August-October 1991-is still seen to be a serious problem for the United States. For example, Asian defense journal articles highlighted the vulnerabilities associated with the coalition's contract surface fleet; had a merchant ship been damaged or sunk, the coalition would have had difficulty finding sufficient ships and crews willing to accept the war risk. These journals also noted similar problems with the Civilian Reserve Air Fleet. ${ }^{23}$

Beyond these reasonably well-recognized shortcomings, foreign militaries commented upon a few specific problems that Iraq managed to pose to coalition forces. Perhaps the two most widely observed coalition shortcomings concemed the general success of Iraqi cover, concealment, and deception (CCD) practices, and the specific ability of mobile Iraqi missiles to evade coalition counter-force operations. ${ }^{24}$

With respect to CCD, former French Defense Minister Joxe has commented that the "relalively simple procedures of hardening sites, camouflage and decoys, and system mobility seriously hampered the task of the most sophisticated means of destruction.'25 The Serbian military noted that the Iraqi tactics of camouflaging, dispersing to outlying small bases, and the use of engineering work and camouflage around aerodromes resulted in a significant degree of protection. ${ }^{26}$

The Israclis, among others, were acutely aware of the unexpected difficulty that the United States had in tracking and attacking mobile missiles. The Israelis estimate the Americans destroyed between zero and fourmissile launchcrs in Western Iraq. This poor performance came as a surprise to ranking IDF personnel. As Chief of Staff Shomron remarked during the war: "I admit that I thought the American operation in western Iraq would end faster. It's taking more time there than we thought. Our assessment was that it would be over in a few days."27 Moshe Arens stated that "prior to the outbreak of the fighting, the U.S. had assessed that it would destroy Iraq's ability to launch missiles within a day or 1 wo." 28

Several other difficulties were noted by foreign observers, including problems operating fixed-wing aviation in bad weather. As one Israeli writernoted: "Despite all the remarkable technological achievements, bad weather may still be a substantial handicap to air operations and especially in its crucial hours." 29 This writer noted in particular that clouds obstructed the functioning of infra-red sensors installed in various aircraft, including the F-117A. The Americans owned the night, but not the weather.

The Italian military, among many others, assume that the limited mine laying operations by Iraq prevented a U.S. amphibious assault against Kuwait. If the Iraqis had mined the open seas as well as the coast, the coalition flect would never have been able to operate within such close reach in the first place, thus downgrading its effectiveness. ${ }^{30}$ 
The coalition also received relatively low marks for the performance of its intelligence services. At the strategic lcvel, the United States-and other regional powers, including Israel and Egypt-obviously failed to anticipate Iraq's initial invasion of Kuwait. Although this failure represents an inherent problem with intelligence-the ability to divine intentions in the face of ambiguous evidence-it was also seen to indicate important weaknesses in human intelligence and analysis. Along these lines, the United States is thought to have significantly overestimated Iraqi military strength in the Kuwaiti theater of operations prior to the initiation of ground combat. The Russian military, for one, felt that the U.S. could have better ascertained that strength through more active ground probes prior to the onset of the land campaign. ${ }^{31}$ Finally, Westem intelligence severely underestimated the scope and sophistication of the Iraqi nuclear program.

At the level of tactical intelligence, the difficulties associated with battle damage assessment (BDA), and problems related to disseminating intelligence to the local commanders, were apparent in many foreign analyses of the war. The official British view was as follows:

The enormous quantities of information collected by modem systems focused on the Gulf generateddifficulties, particularly with the timely delivery of relevant data to field commanders. This problem arose from the complexities of the coalition command structure; the unfamiliarity of coalition operations outside the NATO arca; a relatively unpracticed interface between operations and intelligence staffs; the complexities of the national plan for managing intelligence; and a need to develop further the understandingby operations andintelligence staffs of their respective requirements and capabilities. There were also problems with arrangements for analysis and dissemination of intelligence data. ${ }^{32}$

From the British perspective, JSTARS and TR1 provided good imagery, but the coalition had insufficient imagery from deepcr tactical reconnaissance. The United Kingdom's dcployment of the Tornado GR1a, before trials on its sensors had been completed, helped fill the gap. The German military, for its part, was impressed with the performance of UAVs, but concluded that due to their low overall numbers, they were unable to close the reconnaissance gap left by satellites and manned systems. ${ }^{33}$

The Israeli military commented on the fact that the Iraqis were able to achieve local surprise when they displayed some initiative. As one author noted:

There were a few instances in which the coalition forces nonctheless lacked a comprehensive real-time intelligence picture of the battlefield. These are precisely the cases in which the Iraqi military deviated from its overall passive posture, and attempted original and/or dynamic, if ultimately futile, moves. This was the case with the surprise attack by an Iraqi corps [sic] at Khafji, the operation of surface-tosurface missiles throughout the war, and the dispatch of nearly 150 aircraft to Iran. ${ }^{34}$

The apparent success of the Patriot ATBM has been challenged in the United States by such writers as Theodore Postol; a skeptical view is also held by some foreign observers. The $P a$ triot PAC-2 is thought to have demonstrated some capabilities against SSMs, but the fact that Patriot was designed primarily as an air defense weapon with limited point-defense capabilities against tactical ballistic missiles clearly limited its effectiveness. A common Israeli assessment holds that there is no evidence that Patriot destroyed any SCUD warheads fired at Israel. The al-Hussein missiles had longer ranges and higher velocity than the standard SCUD, against which the Patriot might have performed better. Some of these missiles, accidentally or deliberately, broke upin flight, which complicated the interception problem. Interception also took place too close to the defended area, causing collateral damage. ${ }^{35}$

A certain amount of revisionism about the American/coalition performance during the war has also begun to creep into foreign assessments, including those of China. (In many cases, such revisionism is driven more by poli- 
tics than objective military analysis.) The Iraqi media in particular has started to argue that the Gulf War "revealed many weak points and defects in U.S. weapon systems," such as the Apache helicopter, Patriot, and the Tomahawk cruise missile. ${ }^{36}$

\section{Accounting for the Iraqi Defeat}

From the perspective of most foreign observers, Saddam Hussein was defeated decisively because he placed so much stock in crroneous strategic assumptions. For example, one Italian assessment referred to the failure of Saddam's "political war, which was based on: (1) the involvement of Israel and the Arab abandonment of the coalition; (2) Soviet political intervention in Iraq's favor; (3) the emotional fragility of the U.S. public in the post-Vietnam era; and (4) the force of anti-war movements and the threat of terrorism. When these assumptions failed to be borne out, Saddam found himself fighting a 20th century war against a 21st century opponent." ${ }^{37}$

The Cubans, for their part, argued that Iraq developed a strategy that failed to match its geographic isolation. It could not become another Vietnam or North Korea because those countries "had a rearguard" while "Iraq was totally isolated geographically and would not have either logistical support or the necessary supplies." Most importantly, Saddam had neglected the critical moral facior: Iraq "had a great army, many tanks, mariy things, but its people were unprepared for war." Iraq's will cracked because it did not fight to the last soldier. In Castro's words, "Wars must not be provoked, but once they break out, they must be fought well, and wars must not end without either victory or death." 38

At the operational-strategic level, Saddam is also believed to have relied on a badly mistaken conception-that political considerations would prevent the coalition states from planning military moves on the ground through Iraqi territory. He also misunderstood American war aims, believing they were confined solely to liberating Kuwait. The Iraqis missed an additional U.S. objective: to attrit their war machine in general and nonconventional capability in particular. ${ }^{39}$

There are two overriding reasons generally given by foreign observers for the poor performance of the Iraqi military against the coalition. First, the passivity of the Iraqi military, which led to a loss of initiative. For example, an Indian author argued that

An enlarged Khafji style raid or a major offensive by Republican Guards armored divisions on the offloading ports would have served to inflict fairly heavy casualties and exploited the Vietnam syndrome effect. A few hundred casualties in the initial stage could have had a disproportionate domestic fallout in America and could possibly have stalled the offensive. At the very least, it would have severely dislocated the build-up process and imposed greater caution. ${ }^{40}$

Second, the Iraqi loss of initiative was, in fact, reflective of the fact that Saddam Hussein fought the wrong war, in that he wrongly anticipated both the means and the ends of the American-led campaign. A common Chinese view held that

The reason for the complete defeat suffered [by] the Iraqis before they could put up a forceful fight can be found in their obsolete military theories and their ineffective command and control, not to mention the political factors. One lesson drawn from their defeat is that under modern war conditions, what is fatal in war is not obsolete weaponry, but obsolete, rigid and inappropriate military theories and tactical principles. ${ }^{41}$

Italian analyst Stefano Silvestri contends that Iraq tried to avoid the Egyptian mistakes of 1973 by placing its hopes in a deep, layered front without an axis to exploit-a classic defensc against a blitzkrieg-type assault. However, the Iraqis never faced a frontal tank attack but instcad confronted a much larger penetration axis and a battle marked more by maneuver than frontal assaults. ${ }^{42}$ 


\section{Accounting for the Iraqi Defeat: An "Iraqi" Perspective}

It is very difficult to discem directly Iraqi lessons learned from the war. For obvious reasons, most Iraqis are not inclined to dwell on, or even admit, the failures of the war, especially if those failures could be attributed to Saddam Hussein. It is possible, however, to indicate areas in which Iraqi prewar plans and expectations were proven wrong, and thereby infer how the Iraqi General Staff-generally regarded as being quite competent-might privately assess its performance during Operation Desert Storm. ${ }^{43}$

One critical Iraqi error of judgment and performance concemed the coalition's air campaign. The Iraqis did not expect that they could compete in the air, given the numerical advantages of the coalition, but they sought to survive such attacks as quickly and with as little damage as possible in order to get to the ground war. Here, they thought themselves to have relative advantages, as explained below.

The Iraqis did not believe that air power would be relevant to the ultimate outcome of the conflict. This assumption was based on their own experience in the Iran-Iraq war and on the Vietnam and Middle East wars, where air defenses (especially SAMs) were thought to have prevented the effective use of airpower. The Iraqis believed that they would be able to cause some attrition of coalition air assets, in part through hit-and-run fighter attacks, but mainly through antiaircraft artillery (AAA) and SAMs. The Iraqis did not intend for their air force to engage in a sustained contest for air superiority; their aircraft were to be husbanded in hardened shelters for the postwar period. The key to Iraq's attempts to blunt the air campaign resided in passive defenses: concrete, steel, dispersal, camouflage, redundancy, and frequent relocation.

All the major elements of this strategy to counter the coalition's air campaign failed. The Iraqis had erroneously assumed that the air campaign would be limited to 3-10 days, after which it could not be sustained logistically, and after which it would interfere with the ground campaign. The Iraqi $\mathrm{C}^{3} \mathrm{I}$ system, which had been set up to deal with small raids, failed under coalition attacks. SAMs were neutralized by EW and counter-radar measures (e.g., HARM). AAA had only limited effectiveness; coalition aircraft stayed largely above 10,000 feet, and the $C^{3}$ I collapse led to a breakdown of discipline that prevented effective barrage defenses. The few Iraqi fighters that attempted to ambush coalition forces were defeated by the F-15/ AWACS combination, which the Iraqis had not expected. The coalition devised means to destroy hardened aircraft shelters and thereby threatened the postwar survival of the Iraqi air force, provoking attempts to escape to Iran. Passive defenses were the most successful element of the Iraqi strategy to survive the air campaign, but even these had their limits, in large part because of the unexpected duration of that campaign.

The Iraqi failure to blunt or offset the coalition's bombing was compounded by an erroneous conception of how the ground war would proceed. The coalition's ground campaign was supposed to have been met by a setpiece, infantry-based defense designed to attrit, slow down, and disrupt the enemy attack, with armored counter-attacks to deal with penetrations. The Iraqis had expected that the war would follow the pattem of the Iran-Iraq war, characterized by (a) slowly developing battles, dictated by the pace of the infantry; (b) sporadic fighting, in which actions would be sharp and short, punctuated by a period of delay and regrouping; and (c) a two-dimensional battlefield in which rear areas were relatively secure and in which reserves could form up in relative quiet. The Iraqi military also held to a fundamental belief in the value of quantity over quality. During Operation Desert Shield, Saddam argued that any attempt to dislodge Iraqi troops from Kuwait "would require that they [the coalition] have guaranteed three times the number of Iraq's defending forces ... that is, three million." 44 This presumably referred to the standard dictum that the offense requires a 3:1 advantage over the defense for an attack to succeed. 
The coalition's air campaign effectively destroyed the first and essential element in the Iraqi defenses: the front-line infantry forces, which were of poor quality to begin with, and were decimated and demoralized. The Iraqis were deceived about the schwerpunkt of the coalition's ground attack which they believed would be directed, for political and military reasons, at Iraqi forces in southeastem Kuwait. In part, the Iraqis did not believe that the west was traversable by armored forces off-road, because of the nature of the terrain, which they thought to be too soft and lacking in navigable features. The speed and continuous nature of the coalition's advance gave lie to Iraqi expectations about the nature of the battle (slow, sporadic, and well-defined lines). Unexpectedly poor weather grounded much of the coalition's fixed-wing aircraft during the fourday ground campaign, but coalition (primarily American) armored and heliborne forces obliterated the few Iraqi forces that stood and fought. Here the thermal imaging capabilities of the U.S. Army proved an uncxpected problem for the Iraqis, who lost T-72 tanks without being aware that the enemy was even closing.

\section{Operation Desert Storm and the Changing Character of Warfare}

Many experts in the United States proclaimed that the Gulf marked a revolution in military affairs, picking up on the notion of an emerging "military-technical revolution" that had been advanced by the Soviet General Staff beginning in the late 1970s and early 1980s.

The type of warfare that the United States practiced in Operation Desert Storm did not come as a complete surprise to many foreign militaries, which had been tracking these developments and trying to plan their force structures and doctrines accordingly. In addition to the Soviets, the Chinese and Israelis, among others, had been thinking about the impact of advanced technologies. In the Middle East, those Arab states that were directly involved with the con- flict with Israel (e.g., Syria) or that had close ties with the United States (e.g., Egypt and Saudi Arabia) tended to be at least somcwhat aware of the potential of advanced technologies. But other foreign militaries, especially those that were not closely allied with the United States, did not expect the character of the Gulf War.

In any case, there is today a widespread sense that the Gulf Wardid signal a technology-driven change in the character of warfare. The following assessment from an Indian officer is fairly typical:

The employment of weapons technologies capable of delivering enormous destruction at ever-increasing ranges with improving accuracies, use of advanced surveillance and reconnaissance systems based in outer space and advanced electronic systems for command, control and communications, and other such technological tools has brought a change in the nature of war, by affecting the pace and intensity of war, the area of operation, and even the very principles and objectives of war. Consequently, technological advances have led to far reaching changes in the scope of war and the tactical environment. ${ }^{45}$

The French military was also deeply impressed with the revolutionary character of the technologies displayed during the Gulf War. Former Defense Minister Joxe has argucd that intelligence capabilities, which deserved a "fundamental share" of credit for the coalition's military success, are part of a larger array of advanced technologies, including computers and other information systems and sensors, such as high-precision optical guidance, that together constitute "a revolution in military history." In Joxe's words, "capacitics for listening and seeing into the depth of the enemy's deployment were carried to levels never before attained by electronic warfare means. . . Conversely, these same means were used to render the Iraqi army blind, dcaf, and almost mute." ${ }^{\prime 46}$ This view was echoed by then-Prime Minister Edith Cresson, who stated that future military planning must take into account: 
the growing role that will henceforth be taken, alongside the nuclcar deterrent force and the conventional forces, by a new force whose strategic importance has been revealed by our recent experiences in the Gulf and by the evolution of crisis risks in Europe and the world: the force of space, intelligence and communications. I want to place particular emphasis on this point. A technological revolution has taken place: that of information. It directly concerns our armed forces under the triple aspect of management of the battlefield and chain of command, of detection, and of intelligence. This force enhances the value of the other components of our defense means. ${ }^{47}$

At the same time, there is a strong sense among most if not all foreign militaries that, even if such a military-technical revolution has occurred theoretically, it has limited practical significance for them given fiscal and/or societal realities.

The following section reviews the assessment by foreign militarics of how the character of warfare might have changed. It particularly attempts to ascertain whether forcign militaries believe that the Gulf demonstrated a revolution in warfare. Three case studies follow, portraying Soviet/Russian, Chinese, and Israeli views on the future character of conflict in light of the Gulf War. We then analyze how foreign militaries view specific aspects of warfare in light of the Gulf-for examplc, the role of airpower.

\section{Soviet/Russian Views of Future War}

It is valuable to review Soviet (now Russian) perspectives of the Gulf War, as the Soviets had been in the forefront of thinking about the socalled military-technical revolution. Soviet military forecasters, for example, were among the first to describe the concept of a "reconnaissance-strike complex." 48

There appears to have been a debate in the Soviet/Russian military over how to interpret the Gulf War, a debate marked by overlapping, yet distinct positions. This debate, needless to say, was heavily conditioned by the political implications of various military-technical assessments of the war. ${ }^{49}$

One Soviet view of Operation Desert Storm was held by what might be called the "Old School." According to this view, the Gulf War was not a fair test of doctrine or equipment because of Iraq's ineptness.

A second position on the Gulf War was held by the "Ogarkovites," those associated with the ideas of the former Chief of the Soviet General Staff, Marshall N. V. Ogarkov. Ogarkov's vision of the military-technical revolution(MTR) was confirmed by the Gulf War-but for the Ogarkovites, the war did not signal any radical change in the central importance of ground forces, traditional notions of combined arms in the context of theater-strategic operations, or the necessity to seize/occupy territory.

A third Soviet/Russian perspective on the war could be characterized as "everything has changed"- the Gulf War points to an even more radical alteration in the nature of warfare than that posited by Marshall Ogarkov.

This debate has little immediate practical consequences because of the other overriding pressures now preoccupying the Russian military, but it is interesting to explore in particular the "everything as changed" school because of its prediction of new dimensions of warfare.

One of the principal points of departure for the "everything has changed" school was the inability of traditional Soviet correlation of force models-including those used by the Ogarkovites-to predict the course and outcome of the Gulf War. These traditional models indicated that the coalition would win in about the time that it did, but that it would suffer considerably higher air losses and ground casualties than in fact was the case. This led to an advocacy by the "everything has changed"school of a new methodology that is centered on the correlation of systerns rather than forces.

At the center of this perspective is the belief that future war will be dominated by efforts to disrupt the enemy's, and protect one's own, troop control, through coordinated fire, maneuver, and radio-electronic combat. Each side can 
be expected to optimize its own troop control to maximize the impact of its fire strikes throughout the depth of the theater, while trying to disrupt enemy troop control, leaving the opponent deaf, dumb, and blind, and thereby disaggregating his combined arms capabilities. According to Captain 1st Rank Eduard Shevelev: "The experience of local wars and armed conflicts of the last few years, including the events in the region of the Persian Gulf, has confirmed [that] the course and outcome of military actions depends directly on the capabilities of the opposing side to disrupt troop and force control."so

The successful execution of such strikes can overcome an unfavorable correlation of forces in theater-wide operations. The coalition's superiority in $\mathrm{C}^{3} \mathrm{I}$ and its ability to disrupt Iraqi troop control made it possible to fight an air/ land battle in such a manner as to achieve decisive results against a numerically powerful foe without suffering the sort of losses which would have called into question the limited objectives of the coalition. ${ }^{51}$ Successful wars for limited strategic objectives are now technically, and politically, credible.

From the "everything has changed" perspective, it is therefore critical to reject the "traditional nonsystemic study of the enemy (of the separate organizational structures of the armed forces, of the types of armaments, etc.), but to research his combat systems with their existing functional characteristics and connections." This new approach would make it possible to find the "thin" places or more vulnerable elements of the enemy's combat systems and so make it possible to prevent or disrupt their functioning. Such results may be possible even without the use of fire: "The achievement of these goals, as research studies have shown, can be achieved without fire actions, and only by the use, for example, of means of REC [RadioElectronic Combat], in individual cases by the suppression of individual elements (or their features) of the systems of combat control." 53

The "everything has changed" school believes that future wars that involve advanced technology will look very different from those of the past. Major General V. I. Slipchenko of the Academy of the General Staff has argued that:

The war will proceed without boundaries and flanks. The terms front and rear will be replaced by concepts of 'subject to attack' and 'not subject to attack.' It is presumed that the first targets to be destroyed will be government andmilitary command and control, energy sources, military targets, especially retaliatory strike systems, and other important targets. By concentrating enormous strike power at great depths on the territory of the enemy, not only operationalstrategic goals can be achieved, but strategic ones as well. In fact, the difference between operational and strategic art in such a war will disappear. ${ }^{54}$

In this kind of war, aerospace operations become the primary means to accomplish strategic objectives. The draft Russian military doctrine thus holds that operations during the decisive initial period of war involve "strong air, air defense, and highly mobile assault landing groupings and naval forces to disrupt strategic deployment, disorganize civil and military command and control."s5

Pcrhaps most significantly, strategic objectives - the control or denial of territory - can be fulfilled without physically occupying that territory. In such a highly maneuverable war, linear formations and stable fronts are obsolete. According to one Russian author, "A characteristic fcature of technological war [is that operational goals] can be achicved in definite conditions without the intrusion of ground forces on enemy territory-just through conducting an electronic-fireengagement." 56 Tank-heavy,mass formations are irrelevant; surprise, strategic initiative, preemption, and space systems are critical. Another Russian writer argues that, in the Gulf War, "thanks to surprise, the large force of the blow [and] the massed employment of means of EW, suppression of PVO [air defenses], the disorganization of command and control of [enemy] groups of forces, and the securing of complete air superiority were achicved." 57 


\section{Chinese Views of Future War}

As with the Soviet Union, there are differences within the Chinese military over the character and meaning of the Gulf War. In the People's Liberation Amy (PLA), these differences tend to break down along traditionalist versus modemizer lines. The following is an analysis typical of the modemizers, as articulated by Liu Janglian of the Foundation for International and Strategic Studies in Beijing. ${ }^{58}$

According to Liu, the Gulf War was a prelude to wars of the fourth age-the age of hightechnology conflicts which make comprehensive use of mobility, striking power, protection, and $C^{3} I$ capability. Modem wars are characterized by military high-technology; the close coordination of the Army, the Air Force, and the Navy; modem military theories and tactical principles; and the effective use of military equipment by men. The Gulf War revealed the following characteristics of wars of the fourth age:

- The blending of the front and rear areas, with an extensive deployment of forces in the strategic and tactical depths

- The vertical extension of the battlefield from space to underwatcr areas, with stress on Air-Land and Air-Sea battles, requiring the close coordination of the air, ground, and sea actions

- The great enhancement of mobility characterized by the prompt reaction to events all over the world

- The use of large numbers of PGMs and conventional weapons of mass destruction [sic], with nuclear-biological-chemical (NBC) weapons as their back-up

- The ever-increasing roles of electronic warfare and signal warfare.

\section{Israeli Views on the Future Character of Warfare}

For smaller states, by contrast, the Gulf War did not seem to point towards a revolution in warfare, at least in the nearorintcrmediate term.
This is true even of a nation like Israel, which has always been on the cutting edge of advanced military technology.

From the Israeli standpoint, a revolution in warfare would be characterized by the obsolescence of certain key military systems such as tanks and manned aircraft. Such obsolescence was not indicated by the Gulf War. Tanks have not become obsolete, although they may serve different functions in the future. Ariel Levite describes the key reason why revolution has not yet occurred: "Important as these new technologies may be, they have yet to overcome the Achilles' heel of intelligence"-i.e., the dissemination to field commanders of a comprehensive battlefield intelligence picture and vital target information, as well as battle damage assessment. $^{59}$

The Israeli military is inclined to think less in terms of revolutions in military affairs than in terms of unceasing measure-countermeasure interactions within a relatively constant military framework. At best it is possible to talk about temporary revolutions in warfare. Forexample, the 1973 war suggested to some that advanced air defenses built around SAMs pointed to the end of the manned attack aircraft. But by the time of the war in Lebanon of 1982, the Israeli military had devised effective remedies to the SAM threat. The Americans in the Gulf War demonstrated additional techniques to support an air campaign despitc heavy air defenses.

By the same token, the 1973 war supposedly pointed to the decline of the tank, but the Gulf War was marked by the survival and triumph of the Abrams and Challenger tanks, against which even the more modem anti-tank missiles could not penetrate from the front (and in the future will not be able to penetrate from other angles). IDF experts anticipate that toward the end of this decade tanks will be equipped with "sman" active protective systems against both horizontal and vertical top attacks: hard kill, electronic countermeasures (ECM), and decoy launching. ${ }^{60}$ Over the longer term, tanks will carry a mix of electro-thermal and electro-magnetic guns. This will revolutionize tank design by allowing optimized tank shapes and enhanced survivability characteristics. ${ }^{61}$ 
For the Israeli military, then, the Gulf pointed more towards an ongoing evolution in warfare, whereby there will be a blend of old and new technologies. ${ }^{62}$ One key area for the future measure-countermeasure game will be that of ballistic missiles versus defenses (passive, active, and counter-force).

\section{Specific Trends in Views of Military Affairs}

This section summarizes the Gulf War's impact on foreign perceptions of the following particular aspects of warfare:

- Air power

- Offense-defense relationship

- Surprise attack/preemption

- Relationship between fire-power and maneuver

- Quantity versus quality

- Ballistic and cruise missiles

- Weapons of mass destruction

- Professionalism

- Doctrine, force structure, and tcchnology

- Space systems

- Naval power

Air Power. The war clearly marked a new or renewed appreciation for air power, particularly its utility in the early and perhaps decisive stage of the war. For many states, especially those in the Third World, air power had previously been thought of as an independent arm of strategic bombardment, reconnaissance, and harassment than as a part of an integrated force structure with assigned, organic missions. The apparent failure of the American air campaign against Vietnam had seemed to si nal the limits of conventional airpower for even the superpowers. Foreign militaries are in the process of rethinking the opportunities and vulnerabilities associated with air power in light of the apparently spectacular performance of the coalition's air campaign.

As noted above, there is a view (by no means dominant) in the Russian military that was strengthened by the Gulf War-that aerospace attacks will be the leading edge of future con- flicts and will be a decisive factorin the outcome of those conflicts. ${ }^{63}$ But this view is something of an exception-most foreign militaries are not operating on the assumption that air power will itself be decisive. This conclusion has been reached by the Serbian military, for example; the YPA notes that, in spite of an almost constant 38-day air coalition offensive which employed 80,000 tons of munitions, 50 per cent of Iraq's combat aircraft and 40 per cent of heavy weaponry remained intact..$^{64}$

To be sure, there is a considerably greater appreciation of the fact that success on the ground cannot be achieved in the face of enemy air supcriority. But territory is still thought to matter. From an Israeli perspective, for example, successful campaigns require proper air cover, but forces on the ground win wars. In the case of the Gulf War, it was necessary for the coalition to "materialize Iraq's unconditional defeat" by invading Kuwait on the ground. Operations on the ground were essential to reduce Iraq's offensive potential through destruction of a substantial portion of the Republican Guard, and to ensure that Saddam could not claim a political victory by withdrawing his forces from Kuwait "voluntarily." ${ }^{\text {"65 }}$ The Egyptian military essentially concurs in this analysis:

... despite the coalition's success [in achieving] air supremacy, its air forces were unable to determine the war by themselves, and the ground forces were still needed in order to achieve the overall objectives of the war. In the Egyptians' view, the Gulf War was a war of combined forces, in which the air force had a central role. Its mission was to crode the military capability of the Iraqi forces, to destroy their ability to wage an effective defense, and to prepare the ground for a lightning thrust, with minimal casualties. The ground forces determined the final outcome of battle, in collaboration with other forces. ${ }^{66}$

Under the right circumstances, airpowermight defeat invading forces, but it cannot occupy territory or force a change of regime. Foreign observers note that one of the likely reasons that Saddam did not invade Saudi Arabia is that he 
could not successfully sustain forces across so much territory. By the same token, the Iraqi SCUD attacks demonstrate that missiles simply do not pose the same kind of existential threat to an opponent's regime that ground forces do.

The offense-defense relationship. Most foreign military observers now stress the advantages that advanced technologies will provide the offense over the defensc.

The coalition's performance in the Gulf provided strong ammunition for the professional Soviet (now Russian) military to argue against the "defensive" doctrine that it had previously been forced to embrace in the context of reform. As one Westem expert has noted, "The practical impact of the Gulf War experience has been to kill any lingering ideas about the pre-eminence of the defensive. The offensive is and will remain supreme in Soviet military thinking." 77 Two Russian military writers agree that "modern means of destruction are ablc to make practically any defense unstable, no matter how developed it is in an engineering sense. ${ }^{168}$ Major General Slipchenko asserted that the Gulf War "demonstrated that confining planning to a counter-offensive, as the concept of a defensive doctrine [under Akhromeyev] demanded, would mean surrendering the initiative to the aggressor. This is unacceptable in an era of high-tech weapons." 69 The draft Russian military doctrine still sets out defensive goals, although maximum decisiveness and aggressiveness are required only to carry out specific missions: repelling attacks, delivering retaliatory strikes, eliminating the consequences of aggression and restoring the situation along the border, and disrupting new attempts to renew the aggression. Destroying the aggressor itsclf is not a goal. ${ }^{70}$

The German Ministry of Defense took the Gulf War as a further indication that "defensive defense"- the concept promoted by the left in Germany based on the assumption that advanced technologies would favor the defensewas not viable. For the German MOD, the war demonstrated again that one cannot really differentiate betwecn offensive and defensive weaponry. The difference rather is between of fensive and defensive operations: SAM systems pro- tected the bases of the coalition's offensive; lightly armored forces secured the western flank of the allied ground campaign by deep offensive operations; battle tanks were the main weapon system of all ground forces, in the defensive as well as in the offensive. ${ }^{71}$

Static, barrier-tvpe defenses were seen as being particularly ineffective under conditions of modern warfare. The offense can simply "go over the top" to strike strategic targets while punishing and isolating the defenders, without engaging directly on the ground. From an Indian writer's perspective:

Without an air umbrella, Iraqi troops became sitting ducks in their defenses. . . . Therefore, it all ended up with Iraq's strongest point being its weakest. The US and its allies left the Iraqi defenses to be tackled last while they went in to hit deep inside Iraq to destroy civilian morale, level factories, bridges, airfields and SCUD missile launching pads. In other words, they tried to hit at the fighting will of Iraq and succeeded, after which reducing Iraqi defenses coupled with surprise moves in their rear just became a good joke. .. Saddam Hussein's defensive strategy would have succeeded against a Middle Eastern country, but not against a multinational coalition force in which some of the countries were highly advanced and had superior naval and air power. ${ }^{72}$

The Serbian military (YPA) concluded that the use of positional defense by Saddam was a failure, in that it could only limit the effects of an air attack and could not bring success in battle. Defending entrenched positions was a successful counter-infantry strategy in the war fought against Iran during the 1980 s, but was inappropriate when Iraq was faced with an alliance disposing of immense concentrations of hightechnology weapons systems. The conservation of forces for a decisive battle proved to be disastrous. The clear implication of this lesson for the Serbians is that the enemy should not be confronted with such passivity nor given such a clear run in its preparations. ${ }^{73}$

The Gulf War did seem to point to the fact that armed forces with superior organizational and 
technical capabilities can easily overrun those who are significantly weaker in either or both qualities-this was a lesson that the YPA took away from the Iraqi success against Kuwait and the coalition's success against Iraq. This may seem like an obvious and trivial point, but it suggests that foreign militaries have concluded the following: that the lesson of the Gulf about the importance of quality is not unique to the United States; that qualitative superiority can pay hig dividends in offensive capability against regional opponents; that a defense cannot be established if one is qualitatively inferior (irrespective of any quantitative advantages). In the case of the YPA, this led to what prnved to be an overconfident belief that operations against Slovenia would be a two-day, mini-Desert Storm. ${ }^{74}$

Surprise Attack/Preemption. Related to the previous point about the advantages of the offense over the defense, there are widespread concerns about the possibility that the new technologies $r$. ' iprove the enemy's ability to execute a surprise attack. As noted by the draft Russian military doctrine, "the initial period of war acquires decisive importance."75 The Russian view implies that attempts at mutual conventional deterrence in a crisis would create strong incentives to preempt, give the fact that surprise can have a decisive effect on the outcome of modem war. ${ }^{76}$

For the Israeli military, the Gulf War proved again that strategic surprise (which was achieved by the Iraqis) is still possible despite the most sophisticated means of technical intelligence gathering. From a military standpoint, Israel thus still requires sufficient strategic depth to meet future surprises and initial defensive failures. The Egyptian military, on the other hand, is concerned that

... the use of new technology will improve the enemy's capability of launching a surprise attack, the detection of which would be more difficult than in the past. In this framework, Israel can obtain the technology of the United States used during the war in accordance with the strategic cooperation agreement between them. Hence the
Egyptians take into account that the combination of the exposure of new technologies during the war, Israel's emphasis on maintaining its qualitative edge and the American commitment to it, and its special relationship with the United Statcs might offer Israel new opportunities for achieving ambitions it has long cherished, but did not have the means to realize. ${ }^{77}$

The relationship between firepower and maneuver. A number of foreign observers remarked upon changes in the relationship between firepower and maneuver as revealed by the Gulf War. The Israeli military assesses that the Gulf War marked the continuation of a significant rise in the value of firepower due to the emergence and expansion of precise and smart munitions. In the past, targets could be destroyed by "statistical weaponry" (e.g., artillcry) or by maneuver on the ground; PGMs offer a new means of destruction from a distance B.H. Liddell Hart's indirect approach, in theory, can now be implemented with firepower rather than maneuver. ${ }^{78}$

Quantity versus quality: the economics of high-technology. Foreign militaries are divided on and uncertain about the relative costeffectiveness of advanced technology weapons in the context of their own regional circumstances.

For the Soviet, and now Russian, military, the desire for quality has been manifest since the late 1970 s and early 1980s. The fact that the Sovict military-industrial complex could not provide this was a major factor in the eventual brcakdown of the old political-economic system. But the quantity-quality relationship is not necessarily as direct as it might first appear; quantity of quality, at least in selective areas, can be critical. As Lebedev and others have argued in the context of the Gulf War:

That the command of the multinational forces [MNF] did not seek to achieve gencral quantitative supericity over Iraq in each type of weapon and military technology can be considered a new phenomenon in the strategic deployment of armed forces in the theater of military action. The basic 
attention was paid to the concentration of superiority in quantity and quality of aviation strike forces, naval forces, means of radio-electronic combat, as well as means of collection, processing and dissemination of information, which under modem conditions has become one of the decisive factors in the achievement of victory."79

The Russians also appreciate that there are different metrics that one can use to measure the cost-effectiveness of high-tech warfare. One of the central differences between the Soviet war in Afghanistan and the Gulf War was the fact that the United States and its allies put a high premium on reducing casualties - this was the rationale for the protracted air campaign. ${ }^{80}$

From one perspective, the cost-cffectiveness equation works decidedly in favor of pushing for quality. As one Israeli military specialist noted, small powers "can'tafford dumb bombs," as the Americans did during the Gulf War (referring to the B-52 strikes on Iraqi troop positions). ${ }^{81} \mathrm{Hi}$ n-tech weapons systems and munitions can serve as force multipliers, ease logistic burdens, and compensate for military deficiencies. Chinese military analysts note U.S. claims that 3 percent of total aircraft inventory (F117As) destroyed 43 percent of critical Iraqi targets. The cost of cperating against thick, low-altitude air defenses (e.g., in counter-runway operations) is causing the British to review the mix of precision and nonprecisicn weapons; the UK is now sceking guidance from industry on potential stand-off missiles for use against land-based targets, including runways, to complement the JP233 runway munition. 82

But from another perspective, as some Italian experts have argued, one of the problems with advanced weapons technologies is that one runs the risk that they can be offset with relatively cheap-countermeasures, especially as the networks associated with the employment of those technologies become more complex. For example, $C^{3}$ I systems can be put out of commission by a well-placed bomb on a nodal point; battlefield sensors can be intercepted, destroyed, or deceived. The Italian Army, which is under- going major reductions in force structure, is nevertheless very interested in pursuing advanced technology as a force multiplier, but by and large cannot afford to do so. ${ }^{83}$

For its part, the Spanish military emphasizes the need for selectivity in investing in high-tech, high-cost hardware. According to Spanish Defense Minister Julian Garcia Vargas:

The Gulf crisis has introduced a new dimension in resource requirements by using known technologies but until now not experimented with on the battlefield. The modem weaponssystems have demonstrated efficiency thanks to the use of these new technologies, which are very expensive and require an optimal allocation of the military budget. Putting these modern system in the hands of the SAF [Spanish Armed Forces] in adequate quantity and quality demands a very sei ective acquisition process.... Spain must increment its number of international cooperation programs to share the development expenses of these new systems. ${ }^{84}$

As a rule, smaller powers cannot afford to get caught up in a measure-countermeasure game that involves costs of ever-increasing high-tech weapons. The Vietnamese military, for example, recognizes that its forces should be modemized but that with the collapse of its patron, the Soviet Union, the resources are simply not at hand. ${ }^{85}$ The "costs" of advanced technology are not only economic; they are societal. The Gulf War reminded the professional Iranian military, among others, that there is no short-cut to military effectiveness; the prosecution of a war reflects a society's skills, degree of integration, and level of development. Shahram Chubin noted:

States do not become modern hy buying offthe-shelf equipment; there is no shortcut to military effectiveness such as the cultivation of the military on a fast track over the rest of society. There can be no enclave of (military) modemity unlinked to the rest of society. The prosecution of war reflects a society's skills, degree of integration and level of development. The ability to pros- 
ecute a war in combined arms operations, in intelligence, target acquisition, defense suppression and aerial bombardment, in mobile land operations, in coordinated night attacks, and in logistics and planning, presupposes a level of development that simply doss not exist in developing countries. It is simply not a matter of technology or equipment; it is much more difficult organizational capacity that is nowadays synonymous with development . . . and to some extent with democracy. ${ }^{86}$

Ballistic and cruise missiles. SSMs look increasingly attractive in a regional military context, as well as being one of the few areas in which second- and third-tier states can compete with the major powers. Mobility for SSMs seems to provide real advantages over offensive air operations aimed at destroying those missiles. The effectiveness of Patriot against the Iraqi SCUDs remains a controversial subject, but there is a sense among foreign militaries that more advanced SSMs will have an advantage over $\boldsymbol{P}$ atriot and its successors. Ideally SSMs would complement aircraft, but out of necessity they may have to be used for some missions that would normally be assigned to manned aircraft. Although there is a sense that the SCUD missile class itself will be quite viable in the future, some Third World states may conclude from the Iragi experience that they need more missile 'TELs. The former Soviet Union generally sold on the order of 12-20 TELs to its client states such as Iraq, and the Gulf War experience pointed to the need for a higher number. ${ }^{87}$

One related lesson that some states may have taken away from the war concems SSM firing doctrine: Iraq, for the most part, limited its SCUD attacks to one or a few missiles at a time. The Israelis are concerned that ballistic missile defense will be more difficult, and the impact of SSM attacks more severe, if the missiles are fired in much larger numbers and in a more concentrated fashion (salvo firing). ${ }^{88}$

That said, foreign militaries are by no means ignoring the development of ATBM-capable systems if they are threatened by SSMs from neighboring countries. According to press re- ports, Taiwan is expected to reach an agreement with Raytheon Company jointly to produce modified versions of the Patriot. The collaborative venture, called Modified Air Defense System, will consist of seven units consisting of missiles, launchers, radars, engagement control stations, and support equipment. ${ }^{89}$ For some Third Worldmilitaries, cruise missiles andRPVs may be as attractive a means of weapons delivery as SSMs. Such weapons can be mass produced and are relatively inexpensive compared with SCUDs, and thus can be used to overwhelm defenses. Cruise missiles and RPVs can be made somewhat stealthy and, with the addition of a GPS interface, quite accurate. Such technologies are by no means out of the reach of Third World states, and they lend themselves to cooperative arrangements among pariah states with various sorts of technical capabilities and requirements (e.g., a ChinaNorth Korea-Iran-Syria relationship). ${ }^{90}$

Weapons of mass destruction, especially nuclear weapons. There is a real divergence between the major powers' view of the declining utility of nuclear weapons, and those of someby no means all-regional states, which see the value increasing. This value, as noted previously, is much more political than military. Many analysts in India, for instance, believe that Iraq was on the right track in seeking nuclear weapons, not so much to use them against its adversaries, but as a means of keeping the superpowers out of regional conflicts by raising the risks they would accrue from intervention.

... imbalances of conventional force levels between states can be turned about or negated if one or both of them owns nuclear wcapons. However, the very level of destruction wrought by these weapons and the possibility of setting off a chain reaction which could decimate the entire world operates against the usability of nuclear weapons in war. The utility of such weapons, thcrefore, lies more in their threat of use. ${ }^{91}$

This analysis raises the question of why Iraq did not use chemical weapons during the war. There is some speculation among foreign mili- 
tary specialists that the coalition's air campaign was successful in disrupting Iraqi command and control to the point where chemical weapons use was not practical. The dominant opinion, however, is that Saddam was deterred from such use- that he feared severe retaliation from the coalition, including the destruction of the $\mathrm{Ba}$ 'thist regime and his own removal from power. ${ }^{92}$

Professionalism. The Gulf War strongly pointed to the advantages of smaller, more professional military forces. In nations such as Iran, the PRC, and even Serbia, where there has been an ongoing battle between "professional" and "political/revolutionary" approaches to military affairs, the Gulf War strongly reinforced the position of the former (without completely eliminating the influence of the latter). As one expert on Middle Eastem military forces noted, Iran's experience in its war with Iraq, combined with the outcome of the 1990-91 Gulf War

... discredited the view that ideological commitment, spiritual faith and fervor (the purely human elements) were the sole determinants of victory in war. The Iranians began noting that professionalism; technical expertise; organizational rationalization defined as the elimination of waste and duplication; the establishment of efficient logistics; large-scale acquisition of advanced weaponry and thorough and extensive training in them are of paramount importance in modem war and that a truly effective military should be a function of the synergistic relationship between the human and material elements. In other words modern warfare should be seen as a set of interacting factors among which a balance should be achieved: faith, zeal and courage (the human dimension); training, discipline, preparation and fighting skills (the military organizational dimension) and advanced weaponry (the technological dimension) ${ }^{93}$

As note 1 above, this is easier said than done in terms o hardware for most Third World countries. It may also be difficult in terms of manpower. The partial demobilization of the vast Vietnamese armed forces after their with- drawal from Cambodia, for example, has been delayed because the economy simply cannot absorb the extra people.

For some of the democratic first- and secondtier states, long traditions of conscription-tied in with the notion of citizenship and suspicion of professional armies-is now being balanced with the needs to project power outside the immediate region. In Italy, for example, about 77 percent of the army is composed of draftees; for Rome to have attempted to send ground forces to the Gulf would have set off a political fire storm. Most Italian military officials therefore anticipate either an end to the draft or at least a move to a more professional army, with entire units being made up of professional soldiers. These select units would become the backbone of the army, trained and equipped for multinational operations, and providing credible extra-territorial military action. ${ }^{94}$ For its part, the Spanish military aspires to increase the proportion of professional soldiers to approximately 50 percent of its forces. .5

Taiw'an has a somewhat different problem: it is forced to use a st stem of conscription (with heavy reliance or. reserves) under economic circumstances of essentially full employment and a growing economy. In the aftermath of the Gulf War, the Taiwanese military sought additional information on how the United States maintained its reserves and how it mobilized them for Operation Desert Storm.96

Military Doctrine, Force Structure, and Technology. The Gulf War pointed toward the importance of adapting force structure and doctrine to the requirements of advanced military technology. The professional Chinese military view, for example, calls for

the synchronized development of both technologies and high-tech weapons, and the systematic training of qualified technical personnel. The most prominent feature of high-tech weapons is in organizational coherencc. The more technology-intense the weapon systems are, the more specialized and technical units will be involved, so organizational coherence or the concept of systematization must be stressed. The de- 
velopment of any high-tech weapon system must be synchronized with that of such related systems as intelligence, communications, command and control, supply and maintenance. ${ }^{97}$

For the Turkish military, the "fluidity" of Operation Desert Storm triggered a reconsideration of the entire force structure. This has inclined the Turks to move away from divisions to a more supportable brigade structure that can operate more effectively on the modem battlefield. Turkey is also taking a hard look at its historical problems with the interoperability of forces and is seeking means to improve that situation. ${ }^{98}$

Space systems. As previously noted, the Gulf Warindicated the key and perhaps decisive potential of space systems. The war reinforced Israel's plans to deploy space-based reconnaissance capabilities, and could lead to regional space competition of sorts; Arab states are likely to try to respond in kind, even if only with tum-key systems. The British are currently conducting a review for a new generation of communications satellites to replace theirSkynet system, which will take into account the fact that Operation GRANBY requirements farexceeded anything previously planned outside the NATO area. The British military also discovered GPS receivers proved to be highly valuable; those systems procured during GRANBY will be retained in service and receivers will be fitted to all navy and naval auxiliary vessels.9 ${ }^{99}$ The Indian military appreciated the importance of supplementing space assets with other means of intelligence and reconnaissance, such as JSTARS, in that the Gulf War revealed deficiencies in space-based battle darnage assessment (BDA) plus the expense of space assets.

Naval Power. The Italian military is one of the few that publicly addressed the implications of the Gulf War for future naval requirements. For many Italian analysts, the war illustrated the effectiveness of air-naval power projection through the deployment of carrier-based aircraft and cruise missiles in the absence of land bases. Cruise missiles will, in particular, become essential to national navies as a means of power projection. The fact that these missiles do not require highly-specialized launch platforms may revolutionize the role of naval fleets with respect to attacks on targets ashore.

On the other hand, the Iraqi use of sea mines pointed out the impact that such capabilities might give Third World states in the future, and hence the importance of counter-mine operations. As the technology of mine warfare advances, Italian analysts expect mines to take their place among the range of intelligent weapons. A wider variety of sensors and activation devices will be used in the next generation of mines. Deeper mine-laying will be achieved, and short-tethered and bottom continental shelf mines, capable of releasing self-propelled and self-guided warheads, are on the horizon. For mine hunters, improvements in underwater sensors and new sonar techniques will be the principal means of detection. ${ }^{100}$

\section{The Gulf War and National Military-Technical Adaptation}

In attempting to summarize and assess how these lessons/insights from the Gulf War will affect the plans and forces of foreign militaries, several key points should be made.

First, for most foreign militaries, the Gulf War tended to reinforce and accelerate existing trends and policies, rather than to set them off in a completely new direction. In some cases, the results of the war strengthened the position of certain services or factions in ongoing national debates about future military technology, doctrine, and force development.

Second, no nation is apparently seeking to fully emulate (or compete with) the American approach to war as demonstrated in Operation Desert Storm. For the most part, foreign militaries believe that it is simply too expensive to try to duplicate American technological capabilities across the board. The decisive American edge in the Gulf War was not merely one of superior quality, but quantity of quality. In a recent study, retired General Jean-Claude Coullon, a former Inspector General of the French Army, wrote that the United States spends about as much on intelligence capabili- 
ties as France does on its entire defense budget. ${ }^{101}$ Also, the use of such technolc gy requires an advanced social and education infrastructure, which may not be well developed in many non-Westem states.

Third, most foreign militaries are thinking about selectively incorporating technologies that were demonstrated during Operation Desert Storn, in the context of their own national security objectives and military circumstances. The focus is on a few new technologies that hold out promise of being better able to achieve existing political-military goals, rather than to strive for revolutionary effects on the battlefield.

Fourth, for an increasing number of states, the main concern is less with cxtemal threats than with preserving domestic security and internal political stability. But domestic troubles often have external links which must be addressed, sometimes through military means.

The following sections examine how various classes of national militarics are adapting to the lessons of the Gulf: (1) major democratic industrial powers; (2) important regional states; and (3) potentially hostile powers.

\section{Military-Technical Adaptation by the Democratic Industrial Powers}

The general reaction of these states to the Gulf War-Japan, Germany, France, and to a lesser extent Italy and Spain - was the importance of achieving minimum autonomous national (or regional) capabilities in certain key militarytechnical areas, such as

- survivable command, control, communications, and intelligence

- strategic reconnaissance and early waming (satellites and radar)

- precision-guided munitions

- logistics

- tactical aerospace and ballistic missile defenses.

The objective of these states is not to become the equal of the United States in any or all of these areas, but to meet minimum standards of capa- bility, and address specific or unique national requirements. For example, in the case of logistics, Japan has no need to deploy and sustain tens or hundreds of thousands of troops away from the homeland. But Tokyo would like to be able to deploy and sustain limited naval forces, such as mine sweepers, in the context of multinational operations, as well as support its own peacekeeping forces.

Britain is an exception to this rule. For London, the war reinforced the belief that security lies in close ties with the Americans, and that autonomy is expensive and unnecessary.

The problem with seeking limited autonomy by the other democratic industrial powers, besides the United Kingdom, is one of expense. The areas listed above will strain or exceed the national defense budgets of these nations, which are expected to decline over the next decade. As a result, they will clearly be interested in creative, innovative solutions to address these perceived requirements. Fuel efficient air-breathing vehicles with long loiter times, for example, may be a more attractive option than satellites to provide reconnaissance. For most states, continuous coverage by satellites may be seen as an expensive luxury, and air-breathing systems adapted to the needs of specific contingencies could offer a more achievable and prudent investment.

At the same time, the Westem industrial states now assume that any significant military deployment will be within the context of a multinational force; their need for limited autonomous capabilities will be judged in this context. The so-called Italian new defense model-first formulated in the mid-1980s-served as a basis for evaluating Italian defense needs after the Gulf War. The new defense model provides a good example of where the militaries of the advanced industrial nations would like to go in terms of participating in international military actions. It calls for the development of improved decision-making and crisis-management capabilities; an inde pendent airdefense capability (including AW ACs and tankers to extend the range of fighter aircraft); and air, naval and army forces capable of rapidinterventionin outof-area contingencies. 
The goal of the Italian new defense model is not to create a wholly autonomous Italian defense posture (which is a political and budgetary impossibility in any case), but to possess the ability to counter limited air and naval threats against its territory-most likely coming from the south-and to play a more effective role in multinational military efforts against wider threats to the West. This said, the Gulf War did not create any new impetus to the development of military technology in Italy; in fact R\&D is likely to decline. There is a sense that the Gulf War indicated that, with the collapse of the Soviet Union, the West is so far ahead in technology that it no longer has a pressing need to deploy new hardware. ${ }^{102}$

Along the lines of the Italian defense model, the Japanese Defense Agency (JDA) is also concerned with improving its autonomous capability to defend the home islands, particularly from aerospace attack. In this respect, the Gulf War had little impact on Japanese thinking about front-line equipment and doctrine; Operation Desert Storm instead served primarily to support the justification for systems that were already desired by the JDA, such as aerial tankers. Japanese lessons from the Gulf appear to have been primarily related to the combat support branches, which are less visible to the public and to Japar:'s neighbors. The Gulf War highlighted four areas related to homeland defense where improvements are thought to be particularly necessary: (1) communications; (2) intelligence; (3) electronic warfare; and (4) air defense, including ballistic missile defense. With respect to the latter, the SDF and the JDA are attempting to maximize their capabilities to conduct air defense opcrations beyond the actual airspace of the home islands. A high priority is being placed on the development of an early waming capability with extended detection ranges. Part of this effort involves the completion of the OTH radar facility on Iwo Jima. But it would also require the acquisition of AWACS aircraft, strongly favored by the JDA but opposed by the Ministry of Finance. The JDA has also accorded priority to improving the Patriot missiles in its inventory (which are domestically produced), so that they can intercept tactical ballistic missiles. ${ }^{103}$

For its part, Spain's Gulf War experience strongly encouraged.Madrid to proceed with the development of a Rapid Deployment Force (RDF) that can be used to intervene in out-ofarea conflicts. Spain hopes that its RDF in the future will be capable of playing a role in multinational military operations such as that of Operation Desert Storm. To do so, the Spanish RDF will require adequate firepower, tactical and strategic mobility, operational flexibility, and professionalism, and Spain found itself lacking in many of these respects during the Gulf War.

In the case of the Spanish Army, this means the need for improved artillery with modern fire control systems; helicopters for transport and attack; more advanced tanks and armored personnel carriers; updated anti-tank weapons; and modem ground-based air defense missiles. A modernization program along these lines was in place several years before the Gulf War, but Desert Storm clearly indicated that the Army was following the right track. The Navy's hardware plan calls for the modernization of the Spanish frigate fleet, and the procurement of new amphibious ships, mine counter-measure vessels, submarines, and replenishments ships. The Navy is also interested in creating an airnaval combat battlegroup around its aircraft carrier for employment in out-of-area operations. In light of the Gulf War, the Navy will work to adapt the battlegroup for employment against a possible future threat from the Maghreb. The Spanish Air Force believes that its programs were vindicated by the Gulf - its frontline F-18 aircraft possess night-fighting capabilities, electronic countermeasure capabilities, and PGMs - and that it is accordingly capable of undertaking operations similar to those of Operation Desert Storm. ${ }^{104}$

\section{Case Study: France}

Of the major industrial democracies, France was influenced the most by the Gulf War. The 
warilluminated the difficulties that $P$ aris would have in exerting its political influence under the new global conditions. ${ }^{105}$ As David Yost has argued:

The war brought a greater shock to the French political-military establishment's planning and assumptions about its capabilities and the nation's defense requirements than it brought to some other countries-Britain and the United States, for example. The war has been seen in France as a revelation about changed geostrategic circumstances and the need for fundamental adjustments in France's foreign policies and military posture. ${ }^{106}$

Paris senses that many of the military-technical tools of influence and the policies that it pursued during the Cold War will not be appropriate to the conditions of the new strategic environment. The Gulf War revealed major deficiencies in French military-technical capability that weakenedits diplomatic influence. The experience of the war emphasized France's need to develop the military-tcchnical instruments necessary for effective participation in post Cold-War security affairs, including participation in international interventions outside of central Europe.

To be sure, France's weight during a crisis is relatively greater when the action is at the level of diplomacy in the U.N. Security Council. When diplomacy yields to the usc of force, as it did during the Gulf War, France's limited military capabilities inevitably place it in a secondary position. But at least France, unlike Germany and Japan, faces few domestic or intemational political inhibitions about participating in such actions - and, indeed, has many internal political incentives to do so, including gaining a voice at the postwar negotiating table. The French cannot hope to build an independent intervention capability suitable for large-scale autonomous actions, but they do aspire to build forces that can play a more prominent and effective role in future coalition operations. These military-technical instruments are discussed below. The goal, as President Mitterrand has indicated, is the creation of modem conventional forces capable of intervening quickly and strongly, near our frontiers as well as far away. We must be capable of acting at the side of our allies in Europe, if the situation requires it; of defending our interests overseas; of assuming our obligations where we have signed defense agreements; and of participating the Gulf War demonstrated the necessityin any international action decided by the Security Council or by a future European defense [organization]. ${ }^{107}$

The problem for the French, as with all of the Westem industrial powers, is one of money; Frenchambitions considerably exceed the French grasp. To address this problem, many Frenchmen favor the development of greater Westem European political cohesion and defense cooperation as the solution to France's resource limitations. Unfortunately, the limits of such political and defense cooperation, as noted in the previous chapter, were demonstrated by the Gulf War. European political and defense cooperation would also oblige France to resolve its ambivalence about pooling sovereignty and perhaps to abandon its self-defined status as the world's "third military power."

Two main deficiencies in French military capabilities were revealed by the Gulf War. The first was a lack of intelligence capabilities, especially from space. According to Joxe:

\begin{abstract}
Above all, we must review profoundly our intelligence systems, as much at the strategic level as at the theater and tactical levels. The weakness of these means prevented us from having the necessary information in an autonomous and complete fashion. Without allied intelligence, [which was] American, we were almost blind. To leave our systems in their present state of insufficiency and dependence would amount to weakening our current and futurè defense effort to a considerable extent. In truth, in the long run, we would be disarmed. ${ }^{108}$
\end{abstract}

The second major deficiency was a lack of deployable and sustainable power projection capabilities for use outside Europe. The French 
force sent to the Gulf (the Daguet division) was too light for frontal assaults against Iraqi armored units; it was therefore assigned as a flanking and screening force. Even then, it was necessary to subordinate a brigade from the U.S. 82nd Airborne Division to the French division. U.S. forces provided artillery support. The French military as a whole was excessively reliant on conscripts, who cannot be deployed in combat operations outside of Europe without their consent. The United Kingdom, by contrast, was perceived by Paris to have been much more effective in power projection-it sent 2.5 times more troops and material to the Gulf than did the French_even though the British army is much smaller. ${ }^{109}$

Some French observers have compared the Gulf War experience with that of the Suez conflict in 1956. As a result of Suez, key members of the political-military elite in Paris decided that France must acquire an autonomous nuclear force to maximize its international influence and avoid remaining dependent on the United States. The Gulf War provided a similar revelation: French policy makers concluded that they were excessively dependent on the United States for intelligence, and particularly space-based systems, and that France must therefore develop autonomous capabilities in these areas. Another historical analogy is sometimes made: unless the French military is recast based on the lessons of the Gulf, the French military will be left with the twenty-first century equivalent of the Maginot Line. That is to say, the French believe that their forces were configured wrongly for the type of conflict that was ultimately fought in the Gulf, as they were wrongly configured for war in 1940 .

All of this points to a "new cycle" in French defense policy. In the old cycle, defense policy and procurement were focused on an independent nuclear force, and on conventional forces that were adequate only for shori-term operations in Europe or for light interventions in Africa. The new cycle of French defense policy would ideally be characterized first by autonomous intelligence collection and analysis. This would include a multifaceted space-based capability including optical reconnaissance (the
Helios system), eventually radar and infra-red satellites, a signals intelligence capability, and possibly an early waming satellite. The French MOD has stressed the importance of space systems for "control of air operations, intelligence, anti-missile defense and communications."

The obvious problem with these goals is cost. In part, the French hope to work around the problem by sharing costs with European partners; the Helios system, for example, is funded in part $t /$ Italy and Spain. France could also support the development of a proposed European satellite observation system operated by the Western European Union, which would initially enter service in the year 2000 and be fully operational by 2010 . This system would involve three major sensors: optical photography, infra-red photography, and a synthetic aperture radar. ${ }^{110}$ But there are real doubts about the extent to which other European states will actually contribute to the development of such a system, and also limits on how much France is willing to share the control and intelligence products of its own space-based capabilities. These facts may drive the French to place increased weight on the development and use of less expensive, and more flexible, airbreathing systems instead of satellites.

The second element of the new defense cy le would consist of the creation of a professional power projection force. The goal would be capabilities comparable to those which the British demonstrated during Operation Desert Storm (Operation GRANBY). In principle, this would not require more money, but rather a better organization of what the French already have. In essence, the French would create an allvolunteer rapid action force (FAR) containing an "exportable" heavy armored capability for use outside of Europe, along with a separate staff organization for power projection. Conscript forces would be retained for defense of the homeland and for any revival of a major land threat from the east. Overall, the size of the army is expected to drop from 280,000 to 220,000 troops as part of the emphasis on professionalism. The French would also stress improved training and the use of simulation and 
computer aids, as the American military has done.

As part of this new defense cycle, nuclear weapons will be relatively devalued in French defense planning and investment. President Mitterrand's policy during the Gulf War held that nuclear weapons would not be used in response to a chemical attack. Foreign Minister Dumas went even further, by stating that nuclear weapons "cannot be used except as the ultimate recourse when the national territory is threatened."111 This policy during the Gulf War undercut a major potential rationale for French nuclear weapons in the post-Cold War worldthat of countering (through deterrence, preemption, and/or retaliation) regional powers armed with weapons of mass destruction.

Given the emerging security environment, the French are planning unprecedented reductions in their strategic nuclear program. This includes a reduction of the ballistic missile submarine force from six to four SSBNs. These reductions will be used in part to fund a planned increase in space programs (from 3.5 billion francs in 1992 to 8 billion in 2000). France will by no means abandon its independent nuclear capability, which still confers diplomatic advantages and provides the ultimate guarantee of the security of the homeland. But nuclear weapons clcarly no longer provide the political leverage that they did during the Cold War. The French nuclear testing moratorium of April 1992 is thus by no means anomalous - it is reflective of a sea-change in French perspectives on military power and technology.

Nuclear Weapons and the Democratic Industrial Powers. Ironically, this is one area in which French and British policies seem to be converging. Britain has also determined as a matter of policy that it will try to keep nuclear weapons out of regional conflicts. As Lawrence Freedman has written, "The Gulf crisis raised the question of the readiness to use nuclear forces to deter biological and chemical attacks. In this case at least a capacity for severe retaliation with conventional a s power (as well as defensive measures) plus a deterrent threat based on the extension of political objectives to threaten the Iraqi regime appeared sufficient and that should be the pattern in the future."112

In a September 1992 speech, Defense Minister Rifkind spelled out in some detail the British logic on the nonutility of nuclear weapons in regional conflicts. He argued that a nuclear deterrent would not likely work in the case of a tyrant who is a gambler or an adventurer, or whose judgment is unbalanced or clouded by isolation. "Usable" low-yield nuclear weapons will not be effective as a deterrent, and there is in any case a horror associated with nuclear weapons which the nuclear powers should not attempt to mitigate. Also, public opinion would always think nuclear use disproportionate against a small country or an economically weak one. Hope must therefore be placed in non-prolireration regimes, plus the use of conventional weapons with precision technologies and also precision intelligence. Rifkind also argued that "preemptive conventional strikes against clearlyidentifiable targets under appropriate international sanction are a conceivable option, give the capability of modem conventional weapons, and given the availability of good intelligence."

\section{Case Study: Germany}

The ability of the Bundeswehr to adapt to the lessons of the Gulf War is limited, as in France, by tightly constrained defense budgets, but also by overriding political concerns. The German MOD is trying to change the focus of German military planning from Central Front contingencies to contributing power projection forces to multinational coalitions that are operating outof-region/out-of-area. But the MOD realizes that it cannot get too far out in front of public opinion in this respect. NATO's new force structure, with its heavy emphasis on a Rapid Reaction Force for out-of-region operations, provides the Bundeswehr with a political basis on which to plan for out-of-area operations. As a study of German reactions to the Gulf War noted, "In the often-heard words of German force planners: Fortunately, we have Turkey in the Alliance; almost everything we need in order 
to project forces to eastern Turkey can be used in out-of-area operations as well."113

The financial constraints on the German military leave the Bundeswehr planners with basically two options: they must either postpone certain armament and equipment programs required under the new Bundeswehr force structure until after 1994/95, or radically redesign current prograns to suit the new politico-strategic emphasis on reaction forces. It seems that the services, and particularly the influential Chief of Staff of the Bundeswehr, General Neumann, have chosen the second option. This will likely precipitate a major change in Bundeswehr planning and of the programs launched in the 1980s under the auspices of the Coid War.

From the perspective of the German MOD, the Gulf conflict made clear that for Westem societies at the end of the twentieth century, certain constraints must be observed if the use of force is to be regarded as legitimate. These constraints must be considered in any future military planning and force structure requirements.

- The employment of military forces should take place in a broadinternational coalition, prefcrably under U.N. auspices or at least with a U.N. mandate.

- Military operations must be brief (days or a few weeks). This is primarily a question of superior equipment and weaponry and of well-trained personnel.

- Western democracies are extremely sensitive to military losses, particularly casualties of their own soldiers. Hence all planning has to ensure that military losses are few in order to maintain popular support.

- Forces must have the military-technological capabilities to keep civilian casualties and collateral damage, including ecological damage, extremely low.

These constraints require that strategic-operational planning forregional conflicts be geared to short and-if necessary - massive war fighting. The implementation of such a strategy sets very high requirements in terms of equipment and training of the German armed forces. Two requirements are particularly important in this light: the capability to deliver highly precise munitions over long distances, and forces tailored to rapid deployment via air and sea lift, including geographically flexible logistics. The present military posture of the Federal Republic is ill-suited to fulfill these requirements; to determine how best to address these shortcoming, the German MOD has commissioned studies on long-distance transport (air/sea), longrange communications, "surgical strike" weapons, and logistics.

Bascd on German military assessments of the Gulf War, one might expect any redesign of German forces for out-of-region/out-of-area contingencies to be based on the following points.

First, a greater emphasis on airpower as a tool of crisis management, rapid force deployment, and above all, air-to-ground and air-to-air combat. The German MOD believes that the great success of air power in the Gulf War was largely due to the employment of very modem weapons technologies on a massive scale. Three technologies in particular were seen to have proven their worth, and these may receive greater emphasis in future German force planning: stealth technologies; long-range standoff missiles; and precision-guided munitions. In combinationstealth/PGM or standoff/PGM-they are almost ideally suited to comply with the political postulate to minimize friendly losses and civilian casualties and collateral damage.

Second, the German MOD recognizes that the success of airpower in the Gulf would have been impossible without the enormous contribution of $C^{3} I$ (especially AWACS, JSTARS, reconnaissance satellites, and GPS) and modern electronic warfare. The $\mathrm{C}^{3} \mathrm{I}$ field is of particular relevance to Germany. Strategic $C^{3} I$ is virtually non-existent in the Bundeswehr, in contingencies outside the central region the Bundeswehr would have to rely entirely on allied (i.e., U.S.) assets. In view of the evolving integration proce's in Europe, the German MOD believes that EC partners should try to develop common European solutions, compatible with, while not completely dependent on, U.S. capabilities. 
Unmanned aerial vehicles (UAV) and manned reconnaissance systems will be attractive means of battlefield surveillance for powers that do not have autonomous access to satellite data.

Third, in view of the progressing proliferation of missile technology world wide, Westem forces will have to put increased emphasis on active missile defense in future interventions.

Fourth, modem combathclicopters with highprecision navigation systems and night-vision capability proved their considerable military value to the German MOD under conditions of absolute air supremacy. This may strengthen the case of the Franco-Gcrman helicopterTiger, although the Germanmilitary is not clear whether the present specifications need to be modified in view of the new geostrategic situation.

Fifth, the German MOD is extremely interested in developing mobility across the board (weapons, equipment, and logistics) as the key for the success of future air and ground operations. In the Gulf War, this proved cssential for the survivability of weapons and $C^{3}$ I platforms.

Sixth, the German military realizes that success in the Gulf was the product not only of superior weaponry, strategy, and operational art, it was equally the result of the high quality and professionalism of the soldicrs from the United States, Great Britain, and France. Advanced military technology and intervention missions abroad require above all professional forces. Conscripts are less able to act in a complex military-technological environment, and, for political reasons, they clearly could not be used for out-of-area/out of region operations. The Bundeswehr will have to take this into account as it prepares the forces for contingencies outside Germany and the central region.

Finally, for the German MOD, one of the most important lessons from the Gulf War was the overwhelming importance of industrial support for the success of Desert Shield/Storm. The rapid deployment of forces to unexpected regions and locations (and against unanticipated opponents) requires quick reaction support for maintenance, system modi fications, and logistics by industry. If the German defense industry is to remain creative and fast-reacting with respect to new solutions specifically tailored to future conflicts, it must retain the necessary R\&D infrastructure and technical specialists in place before the conflict begins. The German MOD is also concerned with the problem of retaining industrial capabilities for large-scale reconstitution as well as for Gulf War-type contingencies.

\section{Military-Technical Adaptation by Important Regional Powers}

Important regional states-e.g.,China,Egypt, Israel, and South Korea - have quite a different perspective than do the democratic industrial powers on the meaning of the Gulf War for their own military forces. The democratic industrial powers are largely thinking about military capabilities in terms of their political value, and their utility in international, cooperative military operations - the location and context of which cannot be precisely defined. These regional states, by contrast, have more specific threats against which they plan. These states used the Gulf War as a baseline from which to reevaluate their relative national military status in regional balances of power.

One general point about regional power responses should be noted. The Guif War clearly piqued the interest of foreign militaries in the high-technology systems displayed in Operation Desert Storm (many of which were known and sought-after even before the war). This expressed interest is, however, not always matched by actual procurement. In most countries, budgets rather than military strategy are the dominant factor, and these budgets as a rule are flat or on the decline. With this fact in mind, a technical gap is beginning to open between a relative few second-tier countries ("haves") who are moving ahead of their peers ("have nots"). With a few notable exceptions (China and Iran), these states are pro-American and they are largely buying Westem equipment. ${ }^{114}$

A few other general points can be made about the way that many regional powers are reacting to the Gulf War. 
Air Power and Air Defense. Most states have an increased appreciation of the value of airpower and air defense. Second-tier states are looking to upgrade their existing aircraft (e.g., better radar, fire control, and engines) as a means of avoiding complete obsolescence and providing important multiplier effects. (The effectiveness of such upgrades is also difficult for potential opponents to assess.) Improvements in air defense seem to focus mainly on improvements in command and control, including early waming, and on the modemization of surface-to-air missiles, rather than on fighter aircraft. Along these lines, the United States has noted a sharp increase in the demand for advanced SAMs that possess enhanced anti-stealth capability and that could threaten low-flying U.S. aircraft and cruise missiles. ${ }^{115}$

Focused Approach to Technology. The war pointed to a few narrow technical areas on which regional powers are now tending to concentrate. The most prominent among these are electronic warfare/electronic countermeasures, night combat capabilities, and precision-guided munitions. Other areas of interest include cheap means of surveillance (e.g., RPVs), $C^{3}$, advanced SSMs, and anti-ship cruise missiles with sophisticated countermeasures and precision guidance.

The regional powers are tending to concentrate their resources in a few critical areas, rather than revamp their military capabilities across the board, primarily because of the expense that the latter approach would entail. The Indian military, for example, appreciates the financial limits onits military-technical progress: "In the formulation of this technology-integrated defense strategy and consequent modemization of our army, navy, and air force, certain imperatives of military technology must be kept in mind. The first among these is the issue of cost." Instead of seeking high technology across the board, India should seek "a mix of high and low technology."116 That said, there is little evidence that India, or other regional powers, have actually engaged in very sophisticated planning on how to use such a high-low mix. These states also realize the limits of their societies to produce and operate advanced technologies.

Professionalism. The Gulf War strongly reinforced the importance of professionalism over more politically oriented approaches to military affairs. As a consequence, regional powers are tending to move away from large standing armies towards smaller, more professional, and better-trained forces. In some cases, as discussed below, there may be an interest in moving toward two-tiered forces: a small, highquality, high-tech first-tier force and a larger, mass-oriented second-tier. Such developments may be driven as much by costs as by considerations of military strategy.

Former Soviet Hardware. Some regional powers that have previously relied on Soviet hardware must come to grips with the fact that the Gulf War supposedly pointed to the superiority of Western military hardware. But Soviet hardware has not necessarily becn devalued to regional powers simply becausc of its apparently poor performance in the Gulf War. Iraqi misuse of the Soviet equipment is generally understood. Also systems like the MiG-29 and the T-72 are quite suitable for intemai use and regional conflicts, however inferior they might be to American (or Isracli) hardware crewed by highly trained professionals. The concem of Third World states about acquiring Soviet/Russian military hardware has more to do with uncertainty about long-term assurance of supplies, maintenance, etc., given the conditions in the former Soviet Union.

Regional powers that are committed to Soviet hardware can be expected to try to address specific problems revealed by the Gulf War. For example, note the following Indian assessment:

The superiority of Western tanks, particularly the US M1A1s over the contemporary Soviet T-72s was clearly established to the extent that the latter is clearly not capable of standing up against the former in battle. . The T-72 has proved to be qualitatively inferior to the current Westem tanks, even though in the hands of better trained and motivated troops it may have given a some- 
what better account of itself. . .We must urgently address ourselves to removing as many of their shortcomings as possible. Two of the most glaring ones are its outdated active infra-red night vision system and the inadequate armor penetrating capability of its main armament." 117

Such upgrades of Soviet cquipment with Westem hardware will not be cheap, however, and this may limit the extent to which such "kluges" actually occur.

Ironically, it may be that Chinese military hardware was devalued farmore than that of the former Soviet Union by the Gulf War. Sophisticated foreign military observers noted that much of the equipment destroyed during Operation Desert Shicld/Storm was actually Chinese. Previously, Chinese armor and otherbasicitems were valued by countries that could not or preferred not to buy from the West and that did not want to pay for top-of-the-line Soviet hardware (e.g., Zimbabwe). Now, given the poor performance of the Chincse-supplied equipment during the war (plus the glut of military technology now available on the market), Beijing is facing a substantial loss in its foreign military saies.

\section{Case Study: China}

The Gulf War reinforced and accelerated the PRC's push to modemize its military. ${ }^{118}$ The Gulf War also reinforced the PRC's perception that future conflicts will be local, limited, and conventional. Since the mid-1980s, PRC planning has shifted away from a central concem with fighting a major, protracted war with the Soviet Union to a focus on local, limited wars. ${ }^{119}$ There is explicit Chinese military planning dealing with small-scale conflicts over contested borders, conflicts over territorial seas and islands, surprise air attacks, defense against limited attacks into China, and punitive counterattacks launched by China against regional adversaries. Additional unstated missions of the Chinese military include the use of force to deal wit? cross-border ethnic problems, internal dis- sent and rebellion, and possibly a Taiwan contingency. There has been some discussion of the need to deter United States from intervening against Chinain these contingencies, but whether this concem is significant is not clear.

For these local contingencies, the PLA has established an operational requirement of avoiding a lengthy conflict. China's force-building policy gives top priority to cultivation of elite, rapid-deployment forces for coping with limited conflicts. Chinese forces must be capable of gaining the initiative, and of quick and lethal response. The Gulf War indicated serious deficiencies in PRC military capabilities in all respects, especially technology. The importance of modem technology had previously been understood by the PLA leadership, but the Gulf War indicated the real magnitude of the probiem. Chinese military leaders now publicly estimate the military-technical gap with the West at twenty to thirty years. ${ }^{120}$

Prior to the Gulf War, there was a lingering belief among some in the Chinese leadership that mass and motivation-the "human factor"-could offset technology. This belief was based more on political than on military-technical grounds. It justified increased political control of the PLA, whose loyalty had been suspect during the Tiananmen Square crisis. But even the professional PLA expected that Iraq, in utilizing the human factor, would be able to impose a lengthy and costly war on the coalition, and perhaps even । n. The speed, extent, and decisiveness of the U.S. victory was a surprise to the Chinese, and it reinforced ongoing cfforts to close the gap (or avoid a greater gap) with Westem military capabilities. Beijing's concem is not only with U.S. high technology, but is also driven by fears that Japan's industrial base represents a latent military potential that could be mobilized relatively quickly.

The outcome of the Gulf War thus led the Chinese leadership to accept a return to the preTiananmen Square policy in which future development of the armed forces would put proiessionalism first-not just in technology, but in command system, organization, training, and the like. The govemment's renewed support for 
the military is not simply linked to the Gulf War, but also to the increased importance of the military as an element of comprehensive national security. Beijing is not being stampeded into a large-scale renovation of weapons as a consequence of the Gulf War, however. The military is still following the line adopted in 1979 -i.e., the nation's technological progress has to precede the modemization of military technology, which will be a slow process that relies primarily, although not exclusively, on indigenous efforts. In the wake of the Gulf War, the PLA therefore strongly supports Deng's renewed call for economic modemization.

Technology Priorities. There remain serious obstacles to PLA modemization: an especially poor industrial base and limited access to foreign technology. As a consequence, certain key technologieshave beenidentified forsteppedup development and acquisition. These technologies are intended to compensate for the general backwardness of the armed forces-to "hold the fort"- until the long-term national modemization process is successful. The PLA appreciates that it cannot ultimately hope to compete with advanced military powers based on last year's foreign technology grafted onto a Chinese infrastructure.

It should be stressed that much of the Chinese modernization program was in place or had been emphasized prior to the Gulf War. The outcome of Operation Desert Storm reinforced existing trends rather than send the PLA in entirely new directions. In particular, the demise of the traditional Soviet threat, more than the Gulf War, has caused the PLA to move away from its equipment modemization plans of the 1980s. These plans were focused on the necd to meet the large Soviet armored threat through China's acquisition of improved tanks, multiple rocket launchers, armored personnel carricrs, and the like. Current plans place much greater emphasis on air and naval force modemization to support China's emerging power projection requirements. ${ }^{121}$

The central technology focus of the Chinese military is in the area of electronics. This allows the upgrade of less sophisticated platformswhich China has in abundance-as wcll as providing eventually for completely new capabilities. Electronic warfare/electronic countermeasures (EW/ECM) are receiving particular attention. The Chinese were especially impressed by the coalition's use of EW to suppor air power. They are now attempting to upgrade their own early warning and ECM capabilities. As noted by a PRC Academy of Military Science (AMS) study of the Gulf War:

The air operations in the Gulf War proved that conventional, low-level air defense weaponry cannot resist attacks by hightechnology air power. Our air defense system is extremely weak; it lacks sophisticated early waming, command and control systems, and its countermeasure capability is low. . In modem air attack and air defense operations, seizing electronic superiority is of the utmost importance in gaining the initiative. . Developing sophisticated ECM equipment to raise the level of ECM capability is an extremely important matter in army building. ${ }^{122}$

A sccond area of technological emphasis for the Chinese is in $C^{3} I$, including early waming. The Chinese have noted that coalition $\mathbf{C}^{3} \mathrm{I}$ advantages were made possible by integrated and automated command facilities that allowed for central processing of battlefieid information. PLA studies have accordingly called for the "automation of communications, command and control" in order to face the military challenges of developed countries.

A third area consists of night vision hardware (and countermeasures), a domain which the Chinese believe that the coalition exploited to great advantage during the Gulf War. The PLA hassignificantly upgraded night operations training-focusing on tactical countermeasureswhile working to develop its own NVD technology, such as thermal imaging systems for infantry and helicopters.

Air Power and Air Defense. The Chinese stress the overwhelming importance of air power as the first-and sometimes the only-option in modern warfare. This assessment was strongly buttressed for the Chinese military by the results of the coalition's air campaign. The Chinese 
fear that their own air defense system may have many of the same shortcomings as did that of the Iraqis:

Iraq's resistance to the air raids was not well coordinated and lacked toughness and initiative. This was reflected in the fact that their command was disorderly and inconsistent and could not achieve effective resistance as a whole. Iraq was short of modern means of air defense. In particular, its military command and communications system was very weak. ${ }^{123}$

To deal with these shortcomings, the PLA is taking several remedial steps, including efforts to integrate civil and military air defenses, to develop a unified national intelligence and early waming systcm, and to emphasize air defense missile technology. On this scorc, China is reportedly purchasing advanced SAMs from Russia, including those with ATBM capability. There is also some evidence that the Chinese believe that effective air defenses nced not incorporate a full array of modem technology.

The Chinesc also look to the Gulf War for evidence as to how to improve their of fensive air capability, which is taking on increasing importance as a tool of regional power projection. A PLA publication on the Gulf War "pointed to the need for the air force to enhance its rapid reaction, night and all weather, and ultra-low flying capabilities so that it could cffectively support combined arms operations in a local war environment. The study also cmphasized the need for the Chinese air force to develop sophisticated high-tech night vision equipment and electronic warfare systcms."124

The PLA Air Force is too large and too antiquated to modemize across the board; selective modemization is taking placc instead, with the obvious goal of increasing power projection capability. The Chinese are acquiring some number of Su-27s from Russia (possibly including air-to-ground PGMs), utilizing air refueling equipment, developing an improved air transport capability, and experimenting with airbome early waming assets.

Other Key Military Areas. The smooth integration of multinational forces under a uni- fied commander made an strong impression on the PLA. The coalition's "highly centralized defense leadership organ" was able to blend ground, naval and air forces. "The Gulf War is a practical example of the high-level integration of the U.S. armed forces."125 The Gulf War thus reinforced PLA plans for centralization of command and control- which may be at odds with political pressures to maintain a decentralized system. It also reinforced the Chinese military's view that the lines between strategy and tactics will become blurred during small-scale wars, and tactical actions can achieve strategic objectives.

The imperative for jointness, especially in the context of power projection operations, was also made even clearer for the Chinese by the Gulf War. As the AMS Gulf War study noted, "The Gulf War shows us that modem war is not a confrontation between one or several branches of arms or services, but a contest between integrated forces of various services and arms, and the complementary effects of all weapon systems. The multi-dimensional character of modem war determines the structure of modem troops which is evolving toward the functional integration of all kinds of fighting forces."126 The PLA is currently concentrating the bulk of its joint effort for power projection on small, rapid response units, but after the Gulf War the need for full-scale joint preparation is also increasingly appreciated.

The war strengthened an ongoing Chinese military effort to shift away from ground forcecentered strategies to combined arms. "The results of the Gulf War indicate that, under modem conditions, ground superiority is not genuine superiority in the absence of air superiority. It is difficult to win by relying on a single service, especially on the ground forces alone."127

In the aftermath of Operation Desert Storm, the PLA increased its emphasis on the importance of training, which is a relatively quick means of improving military effectiveness, whereas incorporation of advanced technology takes considerably more time. In any case, training is necessary to operate high-technology equipment. Chinese training has recently emphasized night warfare, rapid reaction forces, 
and armored warfare tactics. But purely military training is not viewed as sufficient-for the PLA, the Iraqi military collapse reconfirms the need for continued political indoctrination. In fact, despite the emphasis on technology and professionalism, the traditional political/ideological elements of PLA military doctrine have by no means disappeared completely:

The practice of the Gulf War indicates that, although high-tech weapons truly played a great role in the war, they are by no means perfect and unconquerable. Their employment and usefulness have certain limitations, and there are ways to deal with them. We should see both their strong and weak points. Tactically we should take modem weapons seriously, but strategically we should despise them. We should overcome the idea that a poorly equipped army cannot accomplish anything in a modem war, and seriously study ways to defeat the superior with inferior equipment." 128

Any Chinese military response to the lessons of the Gulf War thus cannot ignore completely the lingering influence of ideology.

\section{Case Study: Israel}

From the standpoint of Israeli policy makers, the short-term risks of an Arab-Israeli conflict have diminished significantly as a consequence of the Gulf War. ${ }^{129}$ The severe blow that Iraq received to its military forces and infrastructure will rule out the creation of Israel's nightmarcan "Eastern Front" involving Syria, Iraq, Jordan, and Saudi Arabia. Israel can also take comfort in another demonstration that hightechnology weaponry will not work without highly skilled commanders and soldiers; these factors continue to favor Israel over its Arab opponents, even if the Israeli Defense Force (IDF) cannot aspire to a Desert Storm-like capability.

The Israeli military now believes that Iraq received less damage than it first appeared after the Gulf War, but not enough to challenge this basic assessment. Syria is highly unlikeiy to go to war alone; the Gulf War reinforced the earlier message that Syria's superpower patron, the Soviet Union/Russia, would no longer offset the United States. (The Gulf War also reinforced the perception in the region of Israeli conventional military superiority-the United States served as Israel's "proxy" in this sense.) Furthermore, Damascus is still enjoying the political benefits of having joined the coalition, and has no reason to rock the boat by engaging in military provocation to or overt aggression against Israel.

This Israeli perception of a more favorable military balance is tempered, as always, by the recognition that rapid and drastic changes in the region are always possible. The IDF notes the post-Gulf military build-upin Syria (withlongerrange SSMs being of particular concern), Egypt, and Saudi Arabia. Some Israeli military officials also express concern that Arab countries hostile to Israel learned much about new hightechnology systems during the Gulf Warmuch of which Israel relies upon in one form or another. These Arab states are expected to try to use this experience to acquire such technology and to develop countermeasures to it. As more time has passed since the end of the Gulf War, the Israeli military has presented (at least to foreign visitors) an increasingly pessimistic vicw of the regional balance of power and of Arab capabilities. ${ }^{130}$

As a consequence, the outcome of the Gulf War (and the end of the Cold War) do not signal to Israel that if can relax or fundamentally change the direction of its military planning. Political changes can occur much more rapidly than it is possible to (re)build operational military capability. The Gulf War in particular served to reinforce the Israeli military view that tcrritorial depth remains an essential means of hedging against strategic surprise and the possibility of initial defensive failure.

In some ways, Israeli military experts are cautious about the direct lessons that Israel might leam from the Gulf War. Israel will probably never enjoy the kind of advantages enjoyed by the coalition, in terms of time to build 
up its military force during a crisis and to decide unilaterally when the fighting will begin. Israel will not be able to use its air force for such a lengthy period without launching a ground offensive-and the length of the coalition's air campaign is seen by Israel has having been a major factor in the quick and decisive coalition ground offensive.

Precision-Guided Munitions. The results of the Gulf War nevertheless confirmed and strengthened the general direction that the Israeli armed forces had begun to take before the war. The IDF was already well aware of a significant rise in the role of fire-power in the art of war due to precise and smart munitions; Israel has accordingly been pushing to develop PGMs for some time. The debate within the IDF is focused on the allocation of resourcesshould the focus be on deploying advanced munitions in the air force or the ground force?

The emerging role of PGMs in Israeli defense strategy is intended to reduce the attrition of Israeli forces in the early stages of a conflict and thereby improve the combat ratios in the conflict's decisive stage. As noted above, PGMs are too expensive for Israel to deploy in similar quantities to those available to the Americans in Operation Desert Storm. But PGMs can serve as force inultipliers and thus ease the burden of an adverse ratio of forces or compensate for other military deficiencies.

The increasing capabilitics of precision finepower open up new avenucs for the IDF in dealing with Syrian fortifications on the Golan and the Bekaa valley. ${ }^{131}$ Assuming that Israel is not surprised, it has the opportunity to emphasize fire rather than maneuver in the early phase of a war. Traditional Isracli doctrine emphasized maneuver as a way of taking the war to enem y territory, through flanking maneuvers or breakthrough battles. This doctrine has been challenged by the depth and complexity of Syrian fortifications, because of the costs in Israeli lives and time that they might impose. With new technologies, Israeli ground forces could remain initially on the defensive during massive air and artillery strikes against Syrian armor and troop concentrations and airdefenses. These strikes would prepare the battlefield for breakthrough operations.

After the battlefield was prepared, Israel air and ground forces could begin to fight a breakthrough battle by rapidly shifting and massing fire from stand-off ranges, creating gaps in Syrian deployments while minimizing direct contact with the enemy, and thereby reducing friendly losses. The maneuver portion of the breakthrough battle would be initiated once Syrian first-echelon forces had been sufficiently attrited-at least at selected points-and once second- and ihird-echelon forces were reduced by deep strike systems or diverted to protect vulnerable rear areas. Israeli forces could then breach Syrian defenses and defeat Syrian forces in detail through traditional means of fire and maneuver and close-in combat, again with relatively minimal losses. Operation Desert Storm validated concepts and capabilities associated with this style of warfare.

The IDF views PGMs as part of a larger combat system rather than as individual weapons. This system includes the use of RPVs for surveillance and downlinking information rapidly, and the Gulf War served to increase existing Israeli interest in improved means of reconnaissance. The Israeli goal is to be able to observe, orient, decide, and act more rapidly than the enemy, and thereby bring about the degradation or collapse of the enemy's effectiveness without having to engage his forces directly. The fact that Israel's likely opponents, such as Syria, rely heavily on centralized military organizations increases the potential leverage that such advanced weapons systems can bring to bear.

The Ballistic Missile Threat. At the same time that Operation Desert Storm validated a potential new mode of operational warfare for the IDF, the Gulf War also graphically revealed a major problem for Israel: the need to protect the homeland against the threat of ballistic missiles. The Iraqi SCUD attacks pointed to a specific new strategic challenge for Israelbeing attacked from a considerable distance by a country with which it does not share borders. Libya and Iran, as well as Iraq, thus become a 
potential threat to Israel in a way that they were not before-and it is therefore not surprising to the Israelis that such countries are attempting to acquire long-range SSMs.

From the Israeli standpoint, most Arab countries regard SSMs as their "long arm" option, in that Arab air forces are no match for the IAF. The attractiveness of SSMs for the Arab countries undoubtedly increased as a result of the war. Isracli analysts note however that the "Iraqi scenario" is unlikely to be repeated, in the form of repeated SSM attacks in the absence of a simultaneous confrontation on the ground along either of Israel's borders. As an Israeli military analyst has written, "One should not rush to conclude that a fundamental shift in resource allocation toward the defense of the heartland is on order."132

Although the Iraqi SCUDs did not prove to be the ultimate weapon, the missile launches clearly had a traumatic effect on the Israeli population. Isracli defense planners are also concemed that the Arab states may seek to improve their SSM arsenals in terms of range, payload, and accuracy, to the point where they could threaten more than population centers. The concern here is the potential vulnerability of key Israeli military installations (airfields, hcadquarters, and reserve storage facilities) to attack by these advanced SSMs.

Perhaps more importantly, there is widespread concem among the Isracli defense community that Israel's forbearance in retaliating against the Iraqi missile attacks-although politically correct under the circumstances of the Gulf War-may have weakened Israeli's deterrent against various forms of Arab aggression. The fact that Israel's deterrent failed-that Saddam would actually attack Israel with ballistic missiles-came as a surprise to Israeli decision makers. After the invasion of Kuwait, Israeli officials made a number of public statements to invoke deterrence; for example, Prime Minister Shamir stated, "If they dare attack us, they will pay a truly terrible price." Defense Minister Moshe Arens remarked in December 1990, "I don't attach much importance to [Saddam Hussein's] threats to attack Tel Aviv. He's already threatened before. The ability of his missiles to reach Israel is limited, even very limited. Israel leamed all about the Iraqi missiles long ago." 133

The Isracli government assumed, wrongly, that such warnings would be sufficient. After the first Iraqi attacks, Israeli lcaders escalated the tone of their threats, without apparent effect. Some of these threats more than hinted that Israel retained the option of using its supposed nuclear capability should its civilian population come under attack, and some Israeli experts believe that this waming may at least have deterred Iraq's use of chemicals.

In the future, one can expect that Israel will go out of its way to buttress its deterrent and dispel any notions of its lack of resolve. Israel will also work towards a comprehensive strategy to deal with the SSM threat, including such elements as preemption, tactical early waming, passive (civil) defense, active defense, of fensive counter-force, and retaliatory capabilities. The most likely military emphasis for dealing with such threats will be on offensive counter-force. The IDF understands the problems associated with trying to track and destroy mobile missiles, as revealed during Operation Desert Storm, although the Israelis tend to believe that they would have been more successful than was the coalition in such operations. The IDF also understands that Israeli air forces or ground teams would be working at extended ranges. Nevertheless, counter-force operations are relatively attractive because they involve tools that are multipurpose (unlike ATBMs). The Israelis, who operate within tight budget constraints, prefer capabilities that are applicable to a wide range of contingencies, such as strike aircraft, RPVs, satellites, and special purpose forces.

These tools will be part of the Israeli arsenal in any case; the challenge will be to integrate them into an effective counter-SSM force. One Isracli author speculates on the nature of these counter-force operations:

The Israel Air Force has repeatedly demonstrated its capacity to engage in brief surgical long-range strikes against fixed Arab targets. But such a limited strike capacity docs not suffice against multiple and par- 
tially mobile targets, defended by an extensive air defense network and spread over vast remote areas. This requires a massive day/night long-range force projection capability, allowing for sustained, if not continuous, presence, of both air (fixed wing and attack and assault helicopters) and ground (light but well armed commando) forces. It also requires a sizable investment in advanced command and control systems, communications and electronic warfare gear, air refuelling and assault transport capability, and extensive night vision/poor weather operating capability. ${ }^{134}$

Counter-force operations against SSMs also have important virtual effects. The Iraqi SCUD attacks against Israel were less effective than those against Iran during the first Gulf War, in part because the Iraqis could only fire their missiles at night due to the coalition's air campaign, and also because the Iraqis were not able to salvo-fire the missiles after the first few days. Thanks to the Americans, the Israelis additionally enjoyed tactical warning of attacks that the Iranians did not.

The Israelis donot ignore the potential counterSSM contribution to be made by ATBMs, but they note that the development and deployment costs of such systems are exiremely high. The IDF did not rate highly the effectiveness of Patriot in the Gulf War, although the Israelis understand that the Patriot was not optimized for BMD or to meet the longer-range, highervelocity Al-Hussein missile. The Isracli Arrow missile, in contrast to the Patriot, is being designed to intercept advanced SSMs, including those that are equipped with nonconventional warheads, at longer ranges and high altitudes. However, the Arrov' has had development problems and is quite expensive; it also has only modest support in the IDF given the opportunity costs associated with its devclopment. Also, the Arrow would not be able to deal effectively with SSMs that released cluster warhcads containing chemical, biological, or nuclear bomblets early in their trajectory. Israel is accordingly seeking to deploy a modified Python missile on F-15 or F-16 aircraft that can hit SSMs in their boost phase shortly after launch. The Python would eventually be integrated with a large, highaltitude unmanned aerial vehicle now under development. ${ }^{135}$

Given the difficulties and expense associated with a comprehensive defense against ballistic missiles, Israel could decide to turn to more direct approaches. For example, the Israelis could attempt to deter the use of Arab SSMs by threats to retaliate massively; the basis of retaliation could be conventional or nuclear.

Intelligence. The Gulf War reemphasized for Israel the importance of autonomous surveillance and early waming capabilities. Israel is concemed about possible strategic, operational, and tactical intelligence problems that were suggested by analogy in the Gulf War, as well as the political price that Washington might exact if the Israelis remain dependent on the U.S. information monopoly. Existing development programs were accordingly speeded up as a consequence of the war, including reconnaissance satellites, long-range RPVs, and early warning radars. ${ }^{136}$ The most likely candidate for the EW radars is reported to be some derivative of Raytheon's Pave Paws system. ${ }^{137}$

The Larger Strategic Context. The Gulf War marked the first time Israel has had to take an ally's concerns into account in making its battlefield decisions. Because Israel has fought every previous war alone, it had little experience of the sort of accommodation required by coalition warfare. U.S. pressure to refrain from retaliation made sense in the context of the coalition's internal politics, but ran against the Israeli grain. Israel may therefore have to develop new strategies for coalition warfare as the Middle Eastem equation and threats change.

\section{Case Study: Egypt}

Egypt represents an irteresting case study, in that it is a U.S. regional ally whose military was substantially influenced by its experience during the Gulf War. ${ }^{138}$ The exposure of many Egyptian officers to American technolngy and combat doctrine during Operation Desert Storm is likely to have a great impact on Egyptian military aspirations for years to come. The 
Egyptian military saw modem warfare up close; exercises are no substitute for the real thing in developing an understanding of the potential of modern technology and of how better to conduct modem war. The Gulf War also pointed to the value of the joint military exercises held between Egypt and the United States during the 1980s; according to Defense Minister Tantawi, the knowledge acquired by the Egyptian army through these common exercises was one of the main reasons for the quick coordination and the mutual understanding of the combat concepts between the two parties in the course of the war.

The Egyptian military is placing emphasis on building a strong air force and improved air defense system. The Egyptians seem much more optimistic than the Syrians about the utility of air power to survive and be effective against high-technology adversaries; or perhaps Cairo does not expect to fight such adversaries. At the same time, the Egyptians, like the rest of the Arab world, were impressed by the significant psychological impact of the Iraqi missiles in Israel. This suggests that Egypt might regard SSMs, even more than in the past, as a convenient long-range strategic weapon aimed at undermining the enemy's morale and partly offsetting its air superiority.

A second key area of Egyptian military interest is one of developing improved command and control, with large communication networks that are invulnerable to enemy interference. In this arena, Egypt has expressed an interest in obtaining access to satellite data. The war also reinforced Egypt's interest in Apache helicopters.

The Egyptians will accordingly continue to strive to acquire at least part of the American arsenal of advanced technologies. That said, for the most part, these stated Egyptian military priorities have not yet been matched by acquisition decisions. ${ }^{139}$ Egypt's mass conscript ground forces will need a great deal of training and education before they can effectively operate in a high-tech battlefield environment. Making Egypt's mechanized divisions as mobile as Westem ones would take many years and completely new equipment.

Egypt has spent the past two decades responding to the lessons learned in the 1973 Arab-
Israeli war. Some of those "lessons"-particularly the lesson of not depending on a single arms supplier, as Egypt did on the USSR before 1973 - led to mistaken policies, such as the creation of an inventory of weapons from dozens of different country suppliers, weapons not designed for interoperability. The lessons of the 1991 war may dominate Egyptian procurement and training decisions for the next decade or more, but they will not be instantly realized in the armed forces.

Among the lessons that might eventually be assimilated, Egyptians were particularly impressed by the following characteristics of the American-led coalition campaign against Iraq: the combined operations of air and ground forces; deep penetration and the rapid strategic turning movement; and the of fensive against the enemy's depth, outflanking a large portion of its defensive lines.

The Gulf War similarly indicated that some of Egypt's practices and operational concepts were outdated, such as the use of infantry divisions moved by regular vehicles. Egypt also noted the failure of static defenses-these might defeat infantry, but they cannot stop armored units which can outmaneuver and/or penetrate defensive lines with firepower. Finally, Egyptian military specialists have spoken of the futility of stockpiling huge quantities of weapon systems, in vicw of technological progress.

In the future, the Egyptians propose to focus on the coordination of cooperation among air, ground, and naval forces. Especially important is the application of the ground-air concept in rapid envelopment and encirclement operations. The Egyptian military is interested in building its forces so that it can fight in the encmy's depth, simultaneously in several sectors. The forces that will attack into the enemy's depth should be allocated air defense and air support, as well as the necessary administration and logistics.

\section{Case Study: South Korea}

The South Korean military takes some comfort from the commitment of the United States to 
the defense of Saudi Arabia, and from the performance of the U.S. armed forces in the liberation of Kuwait. However, the ROK military also points to the differences between the situation on the Korean peninsula and that of the Persian Gulf. ${ }^{140}$

Analysis performed by the Korean Institute for Defense Analysis (KIDA) points to a coalition advantage of between 5:1 and 14:1 over Iraqi forces prior to the outset of the air campaign, and between an 8:1 and 21:1 superiority prior to the ground offensive. These advantages were based largely on coalition capabilities in air power, $C^{3} I$, and maneuverability. In the case of South Korea, due to its numerical inferiority, limited $\mathrm{C}^{3}$ I capability, defensive positions, and narrow depths of the battlefield, similar calculations show a 0.67:1 disadvantage for the ROK with respect to the North, and at best essential parity (1.03:1) if U.S. forces are included. ${ }^{141}$

From an ROK military perspective, other qualitative factors also distinguish the Korean military balance from that of the Gulf:

- Although neither the Iraqi nor the North Korean forces are well-balanced in terms of force structure, the North Koreans have greater numbers of mobile, light, and commando units; a far supcrior naval force, including a substantial number of submarines; and more bombers (although its air force structure is quitc similar to that of Iraq).

- A North Korean surprise attack would give warning time of only three to four hours; the United States would not have six months to build up as it did in the Gulf.

- Depending on the context in which a war on the Korean peninsula occurred, the United States and the ROK might not be able to gain the kind of international support that proved possible against Saddam Hussein. For example, Russia and China could well pursue policies divergent from U.S. interests and, if not giving outright support for North Korea's war aims, could at the minimum provide sanctuaries for North Korean leaders.
In light of these facts, the South Korean military is concerned with the need to develop increased independent capabilities given the anticipated draw-down in U.S. forces on the peninsula. The Gulf War showed an increased U.S. inclination to "swing" forces from one region to another in the event of regional conflict. The amount of time required by the United States to assemble forces in Saudi Arabia was or concern to the ROK, given North Korea's short-war strategy.

In particular, the war reinforced the South Koreans' belief in the importance of technology. Such capabilities are thought important not only in the context of the requirements to deter or defeat an attack from the North, but also in the context of the security considerations of a future united Korea. In particular, there has been a growing perception of Japan as a potential threat to Korean security - a fact that was even noted of ficially in the 1990-1991 South Korean Defense White Paper. ${ }^{142}$

The ROK is moving accordingly to improve its capabilities in several key areas. This includes the development of a more balanced force structure, spurred in part by the performance of the coalition's air campaign in the Gulf. The current ROK force structure is weighted heavily in favor of the army (88:5:7), based on the assumption of reinforcement by overwhelming U.S. naval and air forces. Recent ROK planning envisages a ratio of 78:10:12 by the end of 1995. The South Korean military is also considering a greater reliance on ground force reserves along the lines of the U.S. total force policy. The ROK is pursuing the creation of an improved, preferably indigenous, $\mathrm{C}^{3}$ I system and the development of new or revised operational concepts (a combined ROK-U.S. Air-Land Battle). The South Korean Air Force has inquired as to the costs of an airbome early waming aircraft, either the E-2C Hawkeye or the AWACS.

There is a strong sense, based in part on the Gulf War experience, that the South Korean Air Force could decisively tilt the balance on the peninsula in favor of Seoul. ${ }^{143}$ The Korean 
Fighter Program (KFP), based on the F-16 airframe, has been modified to take into account lessons from the Gulf War. This has included provisions for better ground attack capabilities, including the ability to mount LANTIRN pods, which the current F-16 force cannot carry. There have also apparently been inquires into the purchase of the Maverick anti-armor missile. The South Korean Air Force has been particularly interested in expanding its electronic warfare capabilities. It has considered but apparently rejected the possibility of purchasing Panavia Tornado ECR variants for suppression of enemy air defense missions-an interest specifically raised by this system's performance in the Gulf War. ${ }^{144}$ As a possible alternative, the Air Force has discussed applying Wild Weasel technology suitable to its F4Es, including the HARM anti-radiation missile. The HARM may also be deployed on the KFP.

For its pit, the South Korean Navy has made improvements in mine countermeasure (MCM) capabilities a priority since the Gulf War. The current naval expansion program includes provisions for twelve to eighteen MCM vessels.

The South Korean military is also concemed with the need to develop anti-SCUD measures. The ROK might consider offensive counterforce operations, centered around F-16 strike aircraft, against North Korean ballistic missile launchers. But the South Koreans cannot help but have noted the coalition's lack of success against Iraqi SCUDs, even under more favorabie conditions of terrain and climate than those on the Korean peninsula. The ROK is therefore likely to put its greatest emphasis on acquiring Patriot to provide active defense against ATBMs, particularly in the region of Scoul, despite the recent criticism about Patriot's performance in the Gulf.

\section{Military-Technical Adaptation by Potentially Hostile Powers}

There is a class of states to which the Gulf War logically should have been of particular int rest: regional powers whose ambitions could bring them, at least potentially, into military conflict with the United States and other advanced industrial nations. For these hostile states, the Gulf War might conceivably represent a fertile "laboratory" from which to take military-technical lessons that might stand them in better stead in the event of a future clash with the Americans. As an American defense official wrote after the war: "Potential adversaries of the United States will take note of Saddam Husscin's shattering defeat and attempt to avoid a similar fate, either by resorting to ambiguous, low-intensity violence or by acquiring their own high-tcchnology military capabilities, or by doing both."145

Surprisingly, military lessons learned seem not to have been the focus of hostile powers as they reacted to Operation Desert Storm. This is not to say that the Gulf War was unimportant; quite the contrary. But rather than provide a blueprint for fighting the Americans, the war instead reinforced the importance of avoiding war with the United States aric other major industrial powers. As noted in a previous section, this does not mean that the hostile powers have abandoned their long-term ambitions or that they will necessarily try to avoid war by appeasing Washington. The pattern is instead one of rinciing ways to move through the pcriod of (temporary) intermational dominance by the United States, to a time when smaller powers will have greater flexibility and room for maneuver. Hostile states remain interested in moving ahead with their regional agendas, but seek to do so at a threshold below that which would trigger external intervention. In short, these states are thinking more about how to manipulate the current political situation to their advantage than about how to fight. ${ }^{146}$

To the extent that Gulf War lessons learned are being applied at the military level, they are fundamentally conditioned by concems other than those of fighting the United States. For most of the hostile powers, the dominant considerations are often as much internal control and prestige as traditional combat effectiveness. Military effectiveness itself tends to be measured more against potential regional adversarics than against the United States. 
That said, hostile powers understand that circumstances beyond their control could bring about conflict with the United States and/or an international coalition. From the perspective of these powers, war is much more likely to occur as a result of miscalculation or American "arrogance," as opposed to deliberate provocation on their part. A few states, suciti as North Korea, are concerned with becoming directly involved against American military power, a larger group of states fears the possibility of U.S. intervention in ongoing regional conflicts. In either circumstance, the limited evidence available suggests that the smaller powers would be inclined to adopt asymmetrical counters to the American style of warfare, and that the Gulf War represents a model (albeit imperfect) of how to prosecute that war. Much of what follows is admittedly speculative, and is based on extensive discussions with regional experts to whom the "what if war occurs" question was posed.

The Outlines of an Asymmetrical Strategy. First, the essential goal of an asymmetrical strategy would be one of regime survival, not military victory over the United States or an international coalition. There is an almost universal expectation that American military action would begin with a strategic air campaign, as it did during the Gulf War. A hostile power's asymmetrical strategy would thus depend first and foremost on avoiding the decapitation of its political and military leadership by that air campaign, especially at the outset of a conflict.

Second, a hostile state would try to prevent or dissuade the United States from "taking Baghdad" on the ground in later stages of the war. The hostile state may be unable to do this by military means, as Iraq could not; it must therefore be sensitive to providing the United States with incentives not to occupy the entire country. The Gulf War, in fact, may have shown that the United States is not inclined to force a regime change through a policy of conquest and occupation. The prolonged difficulties with Saddam after the end of the Gulf War might alter future American war aims to include the replacement of the regime, but this has yet to be demonstrated. Still, hostile states must be aware of staying below key American thresholds - the threshold at which the United States will decide to intervene in the first place, and the threshold of escalating the war to seek the overthrow of the regime. Secretary Baker's threat to Tariq Aziz in January 1991 suggested an important American threshold that might trigger U.S. escalation-the use of weapons of mass destruction.

Third, an asymmetrical campaign by a hostile powerwould seek to seize or regain the initiative by striking at U.S. and coalition centers of political gravity. These centers of gravity are, first and foremost, the American political system and American public opinion, which are arguably sensitive to casualties, the length of the conflict, and collateral damage. (The coalition air campaign, which was regarded as being relatively precise in the United States, was actually considered to be excessive and exorbitantly costly incivilian casualties in many Middle Eastem and Asian circles.) $)^{147}$ These manifestations of the so-called Vietnam syndrome were not necessarily dispelled by the Gulf War, in fact, U.S. tolerance may have actually declined because of the exceedingly high standards for minimizing the apparent costs of war that were set by Operation Desert Storm. The Americanled coalition will have the same sort of sensitivities, and there will be inherent differences of policy and interest among coalition members. Finally, coalition members will be concerned with any threats to their homelands that the hostile power might be able to pose.

In short, foreign specialists tend to regard Saddam's basic approach to the Gulf War as sound, even if his strategy was flawed and poorly executed. The challenge to future hostile powers that might find themselves at war with an American-led intemational coalition is to devise better means to impose costs (casualties, time, collatcral damage) on the coalition-without triggering escalation.

The Means to Execute an Asymmetrical Strategy. There is a strong sense that hostile states confronting the United States in the future will try to optimize the low-technology end of the military spectrum. Cover, concealment and deception will likely rank high as elements of 
any aggressor's strategy against advanced military powers. This is widely recognized as having been the most effective Iraqi tactic during the Gulf War. For the Serbian military (YPA), for example, the Iraqi use of camouflage offered beneficial lessons which "for our armed forces are particularly significant." These lessons included not only the camouflaging of units and firing positions, as well as airfields, but also the creation of false targets using decorative and "sceniographic" methods. Among the specific successes mentioned by the Scrbian military was the use of decoy SCUD launchers. ${ }^{148}$

Cheap countermeasures are another potential means of delaying or disrupting operations by an advanced military power. Mobility seems to be the preferred counter to precision-guided munitions, but obscurants may also be employed to complicate the use of PGMs. Relatively small and inexpensive lasers can blind sensors. Sea mines serve as effective barriers to amphibious opcrations. More ambitiously, hostile states might look to imaginative combinations of dual-use and proliferated technologies, possibly combined with new operational concepts. For example, as the 1992 U.S. Joint Military Net Assessment noted:

The proliferation of high-technology equipment is giving more and smaller nations the ability to employ sophisticated countermeasures against US $C^{4} I$ systems. The rapidly growing use of computers and data networks in command and control applications presents adversaries with targets for exploitation at all levels of conflict. Potential threats are not limited to major military powers. The low cost and compact size of high-technology components make attempts at penetration of computer networks possibly by "hackers," terrorists, drug traffickers, and hostile [states] . . ${ }^{149}$

Because collateral damage in the CNN era can be so politically troublesome, a hosile power might actually seck to "encourage" collateral damage. Rather than just park military aircraft next to historical monuments. a hostik: power could structurally intermingle civilian/ military infrastructures, so that schools are part of nuclear research facilities. The United States might be tricked into attacking civilian targets that scemed to emanate military electronics traffic. Attacks on civilian installations can bc faked. Along these lines, anything that can be done to confuse U.S. and coalition IFF (identification friend or foe) procedures and create friendly-fire casualties would also be of interest.

Hostile powers may well seck means to strike directly at the territory of coalition partners, or even the American homeland. Given the Iraqi experience, mobile ballistic missiles are widely seen to have significant advantages over offensive counter-force and active and passive defenses, and thus are very attractive instruments of power projection. Weapons of mass destruction could be a part of this power-projection packagc. Such a combination of SSMs and wcapons of mass destruction could also conceivably have a serious military effect-e.g., striking against high-value targets like air bases and ports, creating special nuclear effects, and the like. Greater missile ascuracy and specialized conventional munitions for SSM warheads might even provide a credible nonnuclear alternative. And because the United States and its allies are likely to try to improve upon Patriottype ATBM systems, potentially hostile states are likely to explore more advanced offensive countermeasures: e.g., warhead hardening, chaff and decoys, active jamming, stealth, and terminal mancuvers.

Terrorism remains another potential tool to take the war to the enemy, as does ecological and economic warfare (as Saddam attempted by pumping oil into the Persian Gulf and destroying Kuwaiti oil fields). Potential examples of ecological or economic warfare include attacks or threatened strikes against nuclear power plants, civilian chemical production facilities, and electric, financial, and telecommunication networks.

The advantages of trying to strike political centers of gravity in this fashion must be weighed against the possibility that it would exceed American or coalition thresholds and lead to an unwanted escalation of the war that would place 
the regime at risk. This suggests that such means may be thought of primarily as a deterrent-as a way of deterring U.S. intervention in the first place, or preserving the regime if intervention does occur.

Evidence of Asymmetrical Thinking. The Brazilian military has been one of the few sources to speculate overtly, at least in a theoretical sense, what would be required for a Third World state to avoid being "Iraqed." The Brazilian approach rests on two assumptions: first, no single tactic is likely to suffice against an advanced military power, and second, no Third World state can afford the hardware to take on the advanced military powers as well as its regional opponents. Thesc assumptions point toward the advantages of investing in a few select high-technology conventional weapons that could complicate the military operations of an advanced power, and that might also prove decisive in a conflict against regional adversaries. The Brazilians cite especially SSMs, space launch systems, PGMs, and nuclear-powered attack submarines. The lower-tech powershould also exploit variants of irregular fighting, including terrorism and gucrilla warfare, depending on the local conditions. Finally, weapons of mass destruction can serve as a potent counter to the advanced military powers, with nuclear weapons being the clcar preference. ${ }^{150}$

The Polish and Czech militaries have also begun to think about the means to fight a larger and more technologically advanced enemy (in this case, the threat comes from the East and not the United States). ${ }^{151}$ To be sure, these states will be unablc to devote substantial resources to traditional military matters, given the cnormous social, political and economic turmoil that they are undergoing. Still, these states are not oblivious to their short- and long-term defense needs, and they are endeavoring to address those needs creatively.

In this light, the Gulf War confirmed and strengthened the inclination of the Polish and Czech militaries to create a "two-tier" force. The first tier would consist of a small, professional, high-quality force that receives the bulk of funding and training, although it would per- haps consist oí only 10 percent of the total force. The remainder would be taken up by a larger, lower-tech force built around conscripts and heavy armor.

The first-tier force would ideally be built around airmobility (helicopters) and high-precision, deep-strike systems (for maneuver by fire). The purpose of airmobility would be in part to support deep raiding and the intermeshing of forces, as a means of redicing vulnerability to the opponents' advanced technology. Long-range strike systems would be delivered by artillery, rockets, and aircraft. Such high-technology systems cannot be indigenously produced; they must be purchased from other countries, and Poland and the Czech Republic, within obvious financial constraints, are actively seeking to do so.

Some states have little latitude to consider a high-tech option, however limited. In Cuba's case, with the demise of its military connection with the former Soviet Union and the lack of an indigenous arms industry, Havana has little opportunity to move away from a people's war strategy and toward a more professional, highertechnology approach. As Castro himself has noted, the Gulf War and the collapse of Soviet communism "are influencingourmilitary sphere. In all probability, we will have fewer weapons supplied than before. We will have to adapt to this situation, to this reality." 152 Cuba will apparently continue to rely on its traditional approach. In Castro's words:

It doesn't matter how many laser-guided bombs, cruise missiles, or invisible stealth planes they use. Yes, we do not ignore technology, we know it; we do not ignore tcchnical advantages and the number of weapons, but we know what our advantages are, and these are in the heart, and in intelligence, in ideas, and in the method of struggle. ${ }^{153}$

This suggests that there will be no major changes in Cuba's doctrine of the "War of All the People" that draws on the experience of Sovict partisans during World War II, Chinese notions of guerrilla warfare, and particularly 
Vietnamese concepts of "popular and irregular warfare." This doctrine aims at resisting an invasion through social miobilization to supplement the regular armed forces, thereby developing the means of dramatically raising the cost for an occupying force. The Cubans cannot be optimistic, however, that such a doctrine would be successful against a serious American military operation. ${ }^{154}$

\section{Case Study of Adaptation by a Former Adversary: Russia}

The Russian military is actually one of the most interesting sources to look at for evidence about how hostile powers might respond to the American style of warfare. ${ }^{155}$ This is not to say that the current government identifies the United States as a national security threat, or that the Russian military is thinking about the renewal of the global, Cold War rivalry with the United States. In fact, the Russian military is preoccupied with trying just to keep body and soul together at a time of general economic and societal collapse, and what may be the impending disintegration of the Russian Federation.

The Soviet military had been a source for much analysis and insight into the so-called military-technical revolution, as noted above, but the Russian military does not believe that it has anything like the industrial or human resources to pursue the MTR in the foreseeable future. The apparent American execution of a campaign based on MTR technologies and concepts during the Gulf War thus cannot serve as a model for the Russian military, as it might have for the Soviet military a decade earlier.

UnderMikhail Gorbachev, a central objective of Soviet policy had been to slow down the introduction of these technologies into Western arsenals. Gorbachev sought to buy time for Soviet industry (and society) to be restructured completely so as to make the USSR competitive in the MTR, as well as in the world economy as a whole. But by the time of the Gulf War, the Soviet military had already come to realize that the country simply lacked the social and industrial base to sustain the military-technical com- pctition with the West in any significant fashion. The best for which the Soviets might hope was an ability to produce a few specific systems that would be world-class, without any pretensions about participating in the MTR across the board. Thus Soviet national security planners began to tum to offsets to Westem high technology rather than to emulate that technology. This attitude has by and large been inherited by the Russian successors to the Union.

To the extent that the Russian military is planning for future conflicts, it is focusing on the need to employ forces to deal with contingencies in and around the periphery of the Russian federation (e.g., threats to the integrity of the federation or to Russian minorities outside the current borders of Russia). This does not involve MTR-style hardware or operational concepts, but rather the use of light air-mobile forces (including transportable armor) in the context of a rapid-deployment force. Russian air power will be needed to transport the rapid deployment force quickly, keep it supplied, and provide close air support, battlefield interdiction, and air defense.

In thinking throughout the potentral requirements of intervening in these peripheral conflicts, Russian military planners do not ignore the possibility that the United States might intervene to thwart Russian military action. The Russian political leadership does not now assume that such a threat of U.S. intervention exists, but military planners have shown some interest in dealing with such a contingency. These planners cannot completely rule out the possibility that "humanitarian" concerns_or domestic or international political pressureswill provoke U.S. intervention, as was the casc with respect to deploying U.S. forces in northem Iraq to shield the Kurds, and declaring a "no fly zone" in southern Iraq and Bosnia.

If the United States did intervene in a Russian peripheral conrlict, Russian planners do not believe that this would involve a massive global military operation or even U.S. ground forces. From the Russian perspective, the concern is that the United States might attempt to execute a strategic air campaign, disrupt Russian command and control, prevent the Russian air iorce 
from transporting, supplying, and supporting forces in the field, and break down the cohesion of Russian military operations. Such a strategic air campaign would be roughly analogous to that waged against Iraq before the coalition initiated the ground campaign. The presumed purpose of this U.S. threat to intervene, or its actual intervention, would not be to defeat the Russian state militarily, but rather to change the military situation in the region of conflict so as toencourage a favorable political outcome (from the American standpoint).

To address the challenge of American involvement in conflicts around the Russian periphery, Moscow has a menu of political and military choices that are not mutually exclusive. The first is political: Russian analysts such as D. Proekter emphasize that the Gulf War demonstrated that, in the post-Cold Warera, politics control and legitimate the use of force. The United States, or any other power that might contemplate military action against Russia in a conflict along the periphery, must generate and maintain the support of an intemational coalition. ${ }^{156}$

Russian analysts have carcfully studied the Gulf War for ideas about how to limit and prevent the formation of such coalitions. The Russians could themselves scek to intemationalize the conflict by inviting appropriate institutions-for example, the United Nations or the Conference on Security and Cooperation in Europe (CSCE) - to mediate the conflict, and thereby limit diplomatically the ability of any outside state to act militarily. The Russians could also attempt to obscure the fact or nature of Russian intervention through such tactics as the use of "volunteer" paramilitary and indigenous forces, moving under the cover of an appeal from a government-in-exile, and the like. This would be in contrast to the overt and unmistakable aggression of Saddam Hussein against Kuwait.

If such political measures failcd to prevent the formation of an international coalition, Russian military planners would initially focus on deterring the vitervention of that coalition. On this score, nuclear weapons are becoming increasingly salient for the Russians as a deterrent.
Russian military doctrine retains a nuclear nofirst-use policy, but this policy is so highly qualified as to send a deliberately ambiguous message about Moscow's intentions during an actual conflict. Most importantly, Russian doctrine equates conventional attacks against Moscow's strategic $\mathrm{C}^{3}$ I with attacks against Russian strategic forces, in that either could justify nuclear retaliation. In the wake of Operation Desert Storm, Russian military planners may well expect that the United States would begin any action against a Russian deployment force with aerospace strikes against its command and control system. By connecting a nuclear retaliatory threat to such strikes, Moscow can hope to change Washington's riskbenefit calculus away from intervention.

The Russian military will also plan conventional counters to U.S. intervention should it occur. First, Russian deployments in peripheral conflicts must be made rapidly and decisively to get on the ground before the Americans can respond-thus the importance of light air mobile forces. Second, steps must be taken to ensure the maintenance of a minimal $C^{3} \mathrm{I} /$ early waming system, howevermany individual parts of that system may be destroyed. Unfortunately, the breakup of the Soviet Union and the loss of forward air bases/radars in Eastem Europe have greatly degraded Russian strategic air defense capabilities. This suggests that the Russians will increasingly tum to those measures that proved to be relatively successful in the Gulf War against the American air campaign: cover, concealment; and deception (what the Russians call maskirovka). The techniques the Russians are likely to favor include redundancy and the creation of false targets (e.g., dummy radar sites and communications links). The ability to maintain the integrity of operational and tactical air defense systems will be particularly critical. The mobility and maneuverability of airdefense assets-which the Russians criticize the Iraqis for lacking - are attractive means of ensuring survivability of those assets.

The Russians believe that the United States' supply of PGMs is large, but not inexhaustible. If they can force the United States to fall back on 
"dumb bombs" because the Americans have wasted their effort on false or difficult-to-locate targets, the American high-technology advantage will be severely degraded. In short, the Russians could try to encourage American inclinations to use air power for attrition purposes; an American campaign of attrition might have worked against Iraq, but Russia, despite its weaknesses, would be a much tougher nut to crack if it can prevent quick and decisive U.S. intervention.

The Russians may also be interested in more active operations to repel this U.S. aerospace attack, such as striking the sources of the American air offensive. The draft Russian military doctrine signals a continued interest in conventional strategic weapons - "advanced high precision, mobile, long-range weapons . . . as well as [advanced] models of arms and military equipment and intelligence, command and control equipment." These would be used for the "delivery of retaliatory strikes to deprive the aggressor of the opportunity to continue to conduct large-scale military actions, the disruption of his ability to reconstitute his armed forces, and the weakening of his military-economic potential." 157

\section{Case Study: Iraq}

Iraq would seem to be the most natural source to check on Third World military-technical lessons leamed from the Gulf War. ${ }^{158}$ But, in fact, the evidence of real Iraqi military lessons learned is quite limited. To repeat an earlier point: by declaring that the war was a political victory, the Iraqi regime is effectively declaring that concerns about military-technical shortcomings are secondary. The political atmosphere within Iraq does not in any case foster open discussion of matters that might question the competence of the regime. Even within elite government and military circles, honest discussion of the lessons of the war rarely if ever occurs. Saddam and other senior officials are undoubtedly looking for evidence that confirms the wisdom of their original military decisions. Also, there are a relatively small number of high-ranking indi- viduals in the Iraqi regime who could make any authoritative assessment of lessons leamed, and these individuals are pre-occupied with the current day-to-day crises.

During the Iran-Iraq war, the Iraqis did leam lessons; their tendency was to come up gradually with workable and effective solutions, rather than brilliant, quantum leaps. Baghdad's pattem is to try to recognize and work around problems; the Iraqis tend to focus more on what they did wrong than on what they did correctly.

In any case, there are inherent limits to how far certain lessons leamed can be addressed by the Iraqi regime. For example, the Iraqi military undoubtedly appreciates the importance of keeping the military initiative. To the extent that initiative requires decentralization of decisionmaking and the effectiveness of lower echelons, however, it runs into barriers of culture and imperatives of regime maintenance. Limited evidence suggests that the Iraqi military leadership recognizes this trade-off and prefers to err on the side of control rather than initiative.

The Likely Future Trajectory of the Iraqi Armed Forces. The Iraqis did engage in systematiclessons leamed from their war with Iran, and had begun to implement these lessons in 1989 and 1990 before the invasion of Kuwait. For the most part, these lessons, and not those that might have been taken away from the second Gulf War, are likely to dominate the future trajectory of the Iraqi armed forces. Obviously, the military defeat in Operation Desert Storm and the U.N. sanctions/enforcement regime will affect the pace and scope of this trajectory in any case. But Iraq sees Iran, not the United States (or Israel) as its most likely future adversary, which reinforces its continuing focus on the lessons of the first Gulf War. Iraq is also continuing to promote the Iranian threat for political purposes-as a way of trying to revitalizing the informal anti-Iran coalition of the 1980 s, thereby leading to the termination of the U.N. embargo and even Westem and Arab support for building Iraq.

Iraq is likely to build on any responses to the sccond Gulf War by relying on what Baghdad belicves are its core competencies: the ground forces, especially the Republican Guard, and SSMs. 
Since the war, Iraq has turned to an approach that it had begun to adopt after the war with Iran. This involves reducing the size of the army to $350-400,000$ men (down from 1 million), including the disbanding of the popular army, with an emphasis being placed on the Republican Guard and increased mechanization and training. In fact, the core of this restructured force seems to have survived the war largely intact; the bulk of the casualties came from Iraq's low-grade infantry units. The ultimate goal is to create a mobile armored and mechanized force with copious firepower. Such a restructured force will still be no match for the United States, but it would provide Iraq with considerable capability in a regional contexte.g., against Iran or Turkey. In the meantime, the stated tasks of the Iraqi military are to deter attacks on Iraqi territory, restore internal stability, and assist in the reconstruction of the country.

The logical future course for the Iraqi army would be to understand its limits and build primarily on what it is best capable of doing. This includes set-piece offensives, which it did well at times during the war with Iran and during the invasion of Kuwait. Rcliance on set-piece offensives will reinforce the tendency for centralized direction rather than decentralized initiative. A second area of relative competence concems defensive operations from prepared positions, when offensive operations are not possible. Although this clcarly failed against the United States, it is still suitable for Iraq's most likely opponent-Iran-whose military style is one of mass rather than maneuver.

A critical aspect of any Iraqi attempt to regain its place as a regional power will be to reacquire a meaningful power-projection capability through means other than ground forces. The utility of SSMs-in terms of prestige and deterrent value - was clearly demonstrated to the Iraqis during the war. Protection and enhancement of Iraqi strategic programs, including nuclear, chemical, and biological capabilities, clearly have a high priority — probably the highest priority-for the Iraqis. Iraq has struggled to maintain important elements of its weapons of mass destruction and ballistic mis- sile programs, hoping to wait out the United Nations and to rebuild the infrastructure for these weapons once inspections and sanctions cease. Iraq retains key nonfissile materials and equipment, such as centrifuge drawings, machine tools, and expertise that it could use to rebuild a centrifuge-based enrichment effort. Iraq retains a significant amount of production equipment for its chemical weapons program and stockpiles of chemical agents and chemical munitions. Similarly, Iraq has tried to prevent the United Nations from finding and destroying its missile production capability. The Iraqis retain missiles, support equipment, and propellant, and they are still capable of producing SCUD missiles. Iraq's biological weapons capability is perhaps of greatest immediate concern. Baghdad had an advanced program before Desert Storm, and neither war nor inspections have seriously degraded this capability. The dual-use nature of biological weapons equipment and techniques make this the easiest program for the Iraqis to hide. ${ }^{159}$

In addition to their potential utility for prestige and as a deterrent against extra-regional powers such as the United States and Israel, such SSM/WMD programs are aimed primarily at Iran, which Iraq sees as a revanchist country possessing three times its own population.

The arca in which the Iraqis may have leamed the most in the war with the United States concerns air defenses. Here again, the Iraqis are likely to focus on what they do well: passive mcasures-hardening, deception, mobility, and concealment. Since the war, the Iraqis have placed increased emphasis on the redundancy of their systems and have tried to disperse their command and control targets, obviously with the purpose of minimizing the effectiveness of an American air campaign. The Iraqi military understands that it cannot directly challenge U.S. airpower, at least when it is deployed in the quantities used in Desert Storm. However, the Iraqis may be working toward the development of SAM/AA/interceptorcapabilities todeal with smaller, less sophisticated attacks by regional powers, and also to try to raise the price of limited punitive strikes by the United States. 
The strategic utility of a large offensive air capability to Iraq is debatable. Prior to the Gulf War, Iraqi leaders tended to believe that offensive air power could have only limited effects on the course and outcome of an inter-state conflict. During the war with Iran, the Iraqi air force demonstrated limited military effectiveness and it was particularly poor in providing support for ground operations. The Iraqi air force was more valuable as an instrument of regional prestige, as a demonstrator of national competence in high technology, and as a means of exercising internal control. This calculation is not likely to change, given the poor performance of the Iraqi air force during Operation Desert Storm.

The imposition of no-fly zones by the West increases the attractiveness of improving ground forces rather than air forces as a means of dealing with internal security. As noted above, Saddam will also likely place even more emphasis on weapons of mass destruction and ballistic missiles as a substitute for an effective air force as an instrument of power projection. Helicopters, in turn, can provide close air support. Iraqi air power may be best suited for attacks against regional economic targets and battlefield air interdiction (e.g., with chemicals).

\section{Case Study: North Korea}

As a nation which feels itself to be confronted directly by American military power, North Korea had perhaps the most to leam from the Gulf War of any Third World state. ${ }^{160}$ There is unfortunately little public evidence, beyond obviously propagandistic statements, conceming what these lessons might have been. The real decisions in North Korea are made at the top, and American analysts do not have a good feel for the decision-making process during the current planned transition from the leadership of Kim Il Sung to his son.

Some American experts who have traveled to the DPRK over the past two years discern a division in views between Foreign Ministry officials, who have access to the Western media and who were quite impressed with the Ameri- canperformance during Operation Desert Storm; and high-ranking military officers, who tend to be much more insular and who profess that the Gulf War has little applicability to their own situation. In the words of one such officer, "North Koreans are not Iraqis. We will fight."161 For the most part, the North Korean military appears to believe that the Gulf War was an aberration, that an Operation Desert Storm would not succeed against them, and that the DPRK would suffer serious losses, but that North Korea would make the war extremely costly for "invading" forces. The U.S. handling of the Yugoslav crises may also have given Pyongyang a sense of American weakness that could have offset the image of American decisiveness as presented in the Gulf War. ${ }^{162}$

American experts speculate that the Chinese military may have tried to pass along its assessment of the Gulf War to its North Korean counterpart, in orderto drive home the problems that would be encountered in a war with the Americans. Iran too may have passed along information about the war to the DPRK military. ${ }^{163}$ The impact that such possible exchanges might have had on the North Koreans is unclear.

Perhaps the most distressing aspect of the Gulf War for North Korea had to do with the ability of the United States to put together and manage an effective wartime coalition of quite dissimilar powers. The North Koreans are well aware that the last such great U.S.-led coalition was directed against them. This fact undoubtedly increased Pyongyang's sensitivity as to the circumstances under which war on the peninsula might occur (which is not to say that the North Koreans currently desire war). If the war is seen by the international community as one of blatant aggression by the North against the South, the chances of a coalition re-forming would be almost certain. But if the conflict can be portrayed as a civil war (such as those in the former Yugoslavia) - or, better yet, as a case of South Korean/American provocation- the formation of an international coalition might be truncated or prevented altogether. Here the counter-productive nature of Saddam's open aggression against Kuwait must be evident to 
Pyongyang as it is to Iran, Syria, and other ambitious regional powers.

The best military-technical assessment of U.S. experts on North Korea is thus that the Gulf War had a mixed message for Pyongyang, and that Operation Desert Storm largely served to reinforce key elements of North Konea's existing strategy and programs. This strategy includes a strong interest in the acquisition of advanced technology - an interest which increased dramatically after the Gulf War including computer technologies. ${ }^{164}$ Other key elements include:

- Ballistic missiles. The ability of the Iraqi SCUDs to survive the American air campaign was undouhtedly well received by the North Koreans, given their extensive missile protection schemes, which rely on terrain, underground facilities, and various cover, concealment and deception practices. The North Korcans are producing andmarketing extended-range SCUDs (500kilcmeter range) and a new 1,000-kilometer missile that is capable of reaching Japan. ${ }^{165}$ The DPRK is interested in improving missile accuracy as well as range, in that the North Korean military believes that S SMs can have military as wcll as political (i.e., terror) utility.

- Rapid and decisive operations. The North Korean military has long held to a strategy of achieving its military objectives quickly, before the full weight of American military power can be brought to bear. The fact that the coalition's military build-up in Saudi Arabia-Operation Desert Shield-took six months, and that it relied on a relative few naval and air ports of debarkation, probably confirmed to the DPRK the importance of speed and of targeting U.S. logistics and reinforcement capabilities. This fits in with the North Korean strategy of opening a "second front"-striking deep into South Korean territory with missiles and special operations forces (SOF) at the outset of conflict. The SOF would attempt to flood into the South in the early stages of a war, disrupting command, communica- tions and supply, attacking South Korean and U.S. air bases, ports and other facilities, and generally seeking to disrupt military and political operations in the South. ${ }^{166}$ Iraq did not have, or did not utilize, such an option at any point during Operation Desert Shield/Storm.

- Countering U.S. air power. Even prior to the Gulf War, the North Korean military was well aware of the advantages that American air power would provide in a future conflict. The DPRK, like virtually all Third World states, would not attempt to counter a U.S. air campaign primarily through air-to-aircombat, but instead would attempt to orchestrate a multi-faceted response designed to reduce U.S. effectiveness. North Korea, much more so than Iraq, relies heavily on hardened facilitics, and the DPRK has the added advantage of mountainous terrain in which to conceal and bury key assets, including logistics, command and control, military production, and the like. Since the Gulf War, the North Koreans have re-emphasized the hardening and redundancy of these key defense nodes. ${ }^{167}$ There is some reason to believe that the North Korean military assesses the survivability of its hardened facilities as being fairly high despite improvements in American precision/penetrating weapons as revealed in the Gulf. In the past, the North Koreans have planned to rely heavily on night operations to complicate the use of U.S. air power, the American performance in the Gulf at night may qualify if not eliminate this strategy. Finally, the North Koreans plan todisrupt American airpower by attacking air bases during the initial stages of a war. The price that Iraq paid for its inability to disrupt the coalition's air campaign at its source was undoubtedly not lost on Pyongyang.

Such a counter-air strategy might serve to support North Korean defensive operations, but would not necessarily allow the DPRK to operate large armored forces offensively in the south, given the fact that the United States could operate its aircraft (with 
refueling) out of Japan as well as from airfields in southem Korea. The American air performance against exposed Iraqi armored formations must clearly give the North Koreans pause. North Korea's strengths are in fact on the defensive-the advantages of terrain, tunnels, and the likeand in people's war/infiltration tactics. This places North Korea in an awkward position if the goal of its quick military campaign is to unify the peninsula.

- More agile force structure. Over the past decade, the North Koreans have restructured their military around smaller, mechanized and combined arms units at the brigade level. They also have a mobile corps in the rear area for the purposes of exploitation and defense against amphibious attacks. The difficulties that the more traditionally structured Iraqi Army had in the Gulf War are likely to confirm to the DPRK that this reorganization was made along the correct lines. ${ }^{168}$

- Command and control/counter $C^{3} I$. The American strategic air campaign against Iraq focused heavily on disrupting enemy command and control, particularly by taking advantage of Iraq's heavy reliance on centralization. The North Korean military is likely to re-evaluate the potential vulnerability of its $\mathrm{C}^{3}$ I system in this light. Despite the fact that the North Korean military is also highly centralized, it relies primarily on land lines of communication rather than radios, and it has had forty years to prepare for various contingencies. This may persuade the North Koreans that their way of controlling an army is still valid despite the experience of Operation Desert Storm. On the other hand, the DPRK may well attempt to take advantage of perceived command and control vulnerabilities on the allied side-especially those of the South Koreans, who are thought to be considerably less capable than the Americans in this realm.

- Taking advantage of terrain and weather. The terrain and weather in Korea are quite different from that of Iraq, and from that of standard U.S. training ranges, which are also located in desert regions. Korean terrain is mountainous, densely populated in places, and covered by various types of vegetation. Invasion routes across the Demilitarized Zone are limited in number and constrained by terrain. All of these factors complicate mechanized operations but facilitate those of infantry and special operations. The only opportunity for an American-South Korean "left hook" flanking maneuver, such as that carried out in Operation Desert Storm, would be at sea, as at Inchon in 1950. To prevent such an amphibious operation, the North Koreans place heavy emphasis on naval mines, and the DPRK must have taken heart from the apparent effectiveness of the Iraqis in preventing an American seaborne landing against Kuwait. The perception that adverse weather impedes U.S. air operations may incline the North Koreans to time their attack (assuming they control the timing) to coincide with periods during which poor flying conditions are anticipated.

- Weapons of mass destruction. As with several hostile Third World powers, the North Koreans have invested substantial resources in programs to develop weapons of mass destruction. To the extent that the Gulf War highlighted the DPRK's conventional military weaknesses, Pyongyang's incentives to acquire these weapons arguably increased. At the same time, the North Koreans had to be concerned that, with the end of the Cold War, the United States might actually take some pre-emptive military action directed against them, using North Korea's WMD programs as a pretense. For roughly a year after the Gulf War, Pyongyang apparently attempted to control this risk through a ;olicy of conciliation. The North Koreans gave some indications that they might be willing to compromise with the intemational community and abandon, or at least truncate, their pursuit of nuclear weapons. Recent developments, however, indicate that the North Koreans remain determined to acquire such weapons, and that they may have bought 
enough time to achieve this objective, even if international inspections of known DPRK nuclear facilities are eventually allowed. According to CIA Director Woolsey:

For its own part, North Korea gives every indication of hiding evidence of some nuclear-weapons related activity from the international community. Of the greatest concern is the real possibility that North Korea has already manufactured enough fissile material for at least one nuclear weapon and is hiding this from the IAEA. Even if North Korea were to cooperate with the IAEA with respect to the Yongbyon complex, the intelligence community remains concerned that they could still clandestinely develop a small nuclear weapons capability elsewhere. ${ }^{169}$

Perhaps lost in the discussion about North Korean nuclear weapons is its chemical warfare capability. The North Koreans have the capability in principle to deploy persistent chemical agents against airfields and ports of debarkation in South Korea (and possibly Japan), and nonpersistent agents against American and ROK forces in the field. It is not known how Saddam's apparent decision not to usc his chemical weapons against the Gulf War coalition might be viewed by the North Korean leadership.

\section{Case Study: Iran}

Iran represents an interesting case study of Gulf War military-technical lessons learned for several obvious reasons. ${ }^{170}$ First, Iran itself engaged in a major war with Iraq from 19801988 , and thus has a direct means of comparison with the performance of the United States and the coalition. Second, the overt hostility between Tehran and Washington that has held since the hostage crisis, and that included the American "tilt" towards Iraq during the first Gulf War, suggests that the Iranian military will take the prospect of fighting the Americans quite seriously.

Despite these obvious factors, the direction of the Iranian military is still bcing influenced far more by the lessons of the first than the second Gulf War. Tehran is evidently more concemed with the need to fight regional opponents (and to ensure the loyalty of the military) than to face a future Desert Storm. This is not to say that the course and outcome of the second Gulf War was irrelevant to the Iranian military. Rather, the American campaign against Saddam Hussein apparently reinforced the basic conclusions reached by the Iranian military shortly after the end of its war with Iraq -including lessons from Iran's confrontation with the United States in the Gulf in 1987-88. At the broadest strategic level, these lessons can be summarized as "preparedness," "no surprise," and "self reliance."

In addition, it must be stressed that the Iranian response to the outcome of the Gulf War of 1991 will necessarily be heavily influenced by the ideological filter through which any potential lessons learned must pass. As a consequence, Iran is likely to continue along the lines previously established while tinkering at the margins. The force of inertia for Iranian policy makers should not be underestimated, especially if the consequences of "objective" lessons are cxcessively profound or unsettling for a divided political leadership. Any reassessment of Iran's defense posture will be in the framework of the revolution's political values, thought, and ideological baggage. The cardinal features of these values - self-reliance and a strong popularcomponent in national defense-will survive and indeed shape any reassessment.

Iranian Military Priorities. Iran's lessons learned from the first Gulf War emphasized three main military-technical areas for improvement-weapons of mass destruction/ballistic missiles, long-range aircraft for the purposes of power projection, and improved air defenses. There appears to have been some subsequent debate in Iran whether the destruction of Iraq's offensive capability in Operation Desert Storm might allow a slowing down of programs in these areas, so as to divert resources into the domestic economy. Instead, the Iranians appear to see the period after the second Gulf War as one of opportunity to press ahead and take advantage of Iraq's relative weakness. Iran's inclination to cut comers and outsmart the West 
will probably continue and this may result in attempts to gain by clandestine means some of the flashier and more exotic weapons/technologies, if they are available. Still, it appears that Iran has opted for a long-term approach to military modemization while taking advantage of shorter-term opportunities (e.g., the purchase of former Soviet hardware). In fact, because Iran has had no access to reliable military suppliers for more than a decade, the Iranians are now driven as much by what is available in the current arms market as by their strategic preferences. ${ }^{171}$

The top priority seems to be the development of weapons of mass destruction and further improvement of Iran's ballistic missile force. There are several possible explanations. First, this combination would probably be regarded by Tehran as a deterrent against the equivalent capabilities of other powers, such as Israel, as well as a guarantee of the ultimate survival of the regime against external threats. From the Iranian perspective, Iraq's use of missiles and chemical weapons during the Iran-Iraq war was clearly related to the belief that Iran could not retaliate in kind. By contrast, Iraq was presumably deterred from using chemicals during the Gulf War because of the fear of a severe coalition retaliation. In addition, Iranian WMDs/ SSMs will inherently cast a shadow over the region that can provide political advantages and represent a coercive force. (Some Iranian commentators have noted, for example, the potential effectiveness of Iraqi SCUDsin destroying Saudi oil installations. ${ }^{172}$ ) Also, missiles can offer something of a substitute for airpower, especially against a high-technology opponent. ${ }^{173}$ Iran is clearly interested in improving the accuracy of its ballistic missile force to provide a more credible threat against Isracl and Saudi Arabia. ${ }^{174}$

With respect to weapons of mass destruction, recent congressional testimony by CIA Director R. James Woolsey confirmed that Tchran has an active nuclear weapons program. Although Woolsey estimated that it will take at least eight to ten years for Iran to produce its own nuclear weapons, this might be accomplished in less time if Iran receives foreign assistance. The
Iranian program however does not seem to be driven by quite the same sense of urgency and threat that marked the Iraqi program; Tehran's efforts also seem to be more decentralized but perhaps more tightly focused on high-payoff areas than was Saddam Hussein's program. ${ }^{175}$ Iran also has an active chemical weapons program, and biological weapons, if not already in production, are probably not far behind. ${ }^{176}$

Another Iranian military priority is a longrange offensive air capability, which is aimed at providing Tehran with a de facto regional deterrent/power projection capability. This capability will be provided by strike aircraft-e.g., the SU-24 and possibly the Backfire bomberpossibly carrying precision-guided munitions. (Iran is consciously secking to move away from reliance on American aircraft acquired during the Shah's regime.) The idea here is to provide Iran with the ability to "reach out and touch someone"- to send a political and psychological message to its regional neighbors, particularly by holding at risk key economic facilities across the Gulf. Iran's interest in airpower is however functionally limited-it is not aggressively pursuing the ability to provide tactical air support for ground operations, for example. During Iran-Iraq war, neither side was able to mount combined arms operations using airpower tocomplement ground offensives. Consequently, there is still a tendency to view the air force more as an independent arm of strategic bombardment, reconnaissance, and harassment than as part of an integrated force structure with assigned missions that are organically part of an overall battleplan.

The third Iranian military priority concerns improved air defenses. The Iranians tend to focus primarily on fighter aircraft, which accounts for recent purchases of Russian MiG29s with associated air-to-air missiles. (A number of Iraqi MiG-29s flown to Iran to escape the coalition's air campaign have also been retained.) The Iranians are also reportedly attempting to acquire Russian Mainstay AWACS aircraft to improve the command and control of their air defenses. Surface-to-air missiles are of secondary interest because of anticipated difficulties with command and con- 
trol, although again the Iranians are expected to purchase some former Soviet hardware (e.g., the SA-5). Iran is currently undertaking the development of an indigenously-produced fighter, ${ }^{177}$ as well as purchasing foreign aircraft to build upon the "bonus" provided by the Iraqi air force during the war.

Upgrades in air defense capability will begin with protection of the Iranian heartland, then push out to offer protection of border areas. The air defense program seems to be aimed primarily at potential regional adversaries such as Iraq; there is apparently no effort to develop an air defense system capable of meeting a Desert Storm-style air campaign waged by a hightechnology adversary like the United States. Like Iraq, however, Iran is striving to protect its strategic industrial infrastructure from air attack by imbedding it in the civilian economy, as well as through measures of dispersal and concealment. Fear of air strikes by the United States is one motivating factor for these efforts. ${ }^{178}$

The Iranian military also seems inclined to enhance its ability to control, or at least deny access to, the Strait of Hormuz. The acquisition of Kilo-class submarines from Russia, ${ }^{179}$ recent maneuvers involving the amphibious landing of marines on a hostile shore, efforts to achieve greater long-range air projection, and the full annexation of Abu Musa island (possibly as a site for a Silkworm brigade) point to an Iranian intention to control shipping lanes just inside the Strait. Iran might also contemplate using the submarines to control access to the Strait from the Gulf of Oman. Clearly, Iran is not going to be able to deny the strait to the U.S. Navy, but this may not be its real goal. The ability to interfere with regional tanker traffic, as was done in 1987-88, may be the immediate goal. Part of this campaign coulc include direct attacks on Saudi Arabia and the coastal Arab states.

Beyond these three areas of emphasis, the Iranian military recognizes the serious weakness of its ground forces, but it has not given priority to the rectification of these problems. Iran probably bclieves that it can defend against a wcakened Iraqi army over the short and medium-term using its advantages in manpower and support (logistics). A new strategy based on speed, maneuver, and high-technology, while perhaps desirable, is unnecessary and too costly. Over time, Iran may be able to take advantage of a "buyer's market" in military hardware to upgrade its ground forces, but Tehran believes that it can now afford to wait and buy selectively. The Iranians are restocking largely with former Soviet equipment (e.g., the T-72) in the belief that the performance of this hardware cannot be fairly judged on the basis of the Gulf War. In the long-run, Iran may also be able to rely increasingly on domestic industries for equipment good enough to meet a threat from a weakened Iraqi army.

The Iranian military is undergoing a major reorganization. Attempts are being made to merge the Revolutionary Guards (Pasdaran) and regular army for the sake of efficiency and professionalism. The Revolutionary Guard's lesser units will be relegated to reserve duties while the better units will be merged into the regular army. This is another step towards the professionalism that Iran now sees as crucial to the future of its military capability. But in addition to limited resources, the Iranians are still having doctrinal and organizational difficulties, which includes the Pasdaran's resistance to a merger with the regular army. The civilian govemment also continues to fear the army as a potential center of a future coup.

During the Iran-Iraq war, the Iranians suffered badly from unintegrated and uncoordinated ground campaigns fought without air assets. As a consequence, the Iranians have made halting attempts to develop a combined arms capability as well as to integrate better fighting systcms in general. In the spring of 1992, for examplc, Iran undertook several combined arms exerciscs in the region around the Strait of Honnuz. These exercises involved armored and infantry divisions, airborse brigades, artillery, army aviation, air force fighters, combat engineers, the Revolutionary Guards Corps, and gunboats equipped with SAMs. The exercises included close air support exercises and defense against 
chemical attack. The stated objective of these exercises was to secure the strait from enemy penetration into the Gulf. ${ }^{180}$

The Ideological Dimension. One further lesson of the Iran-Iraq war, as reinforced by the second Gulf War, is worthy of some attention. During the Iran-Iraq war, Iran had extolled the importance of commitment, will, and the motivation of society for sacrifice and the willingness to take punishment for a morally righteous cause. The emphasis on élan, determination, and steadfastness had been at the expense of concern for professionalism, expertise, discipline, or technology; the man was more important than the weapons system, and the best material for the armed forces were committed Islamic revolutionaries, not professional soldiers or technicians. This fit in well with the revolution's aim to build up a revolutionary guard corps tooffset dependence on a politically unreliable military. In time, self-reliance became not simply a slogan or aspiration but a reality, as Iran's policies turned off more and more potential sources of weapons.

In the end, however, Iran lost the first Gulf War on its own terms-not because of inadequate arms but inadequate commitment. The end of the war therefore catalyzed a re-examination of Iran's defense thinking. Although the Iranian government continued to stress the selfreliance and the superiority of the committed soldier to the technologically advanced one, it did so in a new context. It was clear that even before the Iraqi invasion of Kuwait, Iran was struggling to reconcile its values and objectives and the needs of its defense forces-specifically, the need for advanced weapons and military professionalism, while still avoiding dependency on foreigners and relying on Isiamic devotion and faith.

The experience in the war with Iraq, and the second Gulf War, clearly supported those in Iran who favored technology and professionalism, although these cannot be justified outside of a revolutionary context. For example, if Iran must import military technology from the West, it must ensure, in the words of Ayatollah 'Ali Khamene'i, "that only sciences should be ac- quired from foreigners, and that their corrupt moral and polluted ways should be eschewed."181

\section{The Bottom Line: Technology Matters}

The Gulf War demonstrated to virtually all foreign militaries the salience of advanced technologies in regional conflicts-or perhaps more accurately, the war illustrated the unexpectedly serious consequences of being on the wrong side of a military-technical "gap." That said, the Gulf War did not generate a military-technical competitor to or emulator of the United States. Foreign militaries will instead adapt the technologies and operational concepts displayed in the Gulf War in the context of their own particular domestic and regional circumstances. In many cases, plans and programs for advanced technology were already in train before the war; the success of Operation Desert Storm only served to reinforce these plans and programs. In the view of most foreign militaries, Iraq lost because it fought the wrong war, but neither is the American way of war necessarily the right way for most states.

Because foreign militaries are adjusting to the Gulf War in selective and incremental fashion, the war itself did not point to a practical revolution in military-technical affairs for any nation other than the United States. The warclearly did signal an increase in foreign assessments of the relative importance of aerospace operationsmanned aircraft, helicopters, space systems, PGMs, UAVs/RPVs, cruise missiles, ballistic missiles, ballistic missile defenses - as a means of power projection and as a potentially decisive (although not necessarily a war-winning) instrument of warfare. Electronic warfare and night vision devices are other technology areas with which foreign militaries were particularly impressed. Foreign militaries will tend to focus on one or two of these critical, but narrow, technology areas. The perception of the value of military professionalism and quality (relative to idcology and quantity) was strongly enhanced by the Gulf War. 
The technologies associated with the Gulf War were widely seen to increase the inherent advantages of the offense over the defense. Surprise, preemption, seizing, and retaining the initiative, denying the enemy time to build up forces, are associated with this perception of the advantages of the offense over the defense.

In the aftermath of the Gulf War, weapons of mass destruction (coupled with mobile SSMs) appear more attractive to states that cannot bridge the technology gap with more advanced military powers. However, the path to acquiring WMDs may be fraught with danger, including intemational sanctions and preemption. Passive defenses and mobility, plus asymmetrical strategies and tactics, are other key means of engaging advanced military powers. The focus, however, will be on political strategies based on war avoidance and regime survival if war does occur, rather than on military strategies focusing on operational effectivencss and victory.

That said, we still have not seen the other shoe drop: do hostile powers envision ways to disrupt U.S. military centers of gravity-logistics, command and control, and joint operationsand not just political targets? The United States needs to be aware of the emergence of innovative doctrines, imaginative combinations of foreign-acquired and domestically-produced technologies, and the development of high-technology enclaves. The Gulf War wilt in any case be a central reference point for any foreign military that desires to move up to another level of technological capability, especially if it seeks to meet an advanced military power on more equal terms. Foreign militaries can thus be expected to continue the "lessons learning" process for some time, perhaps after a period of apparent indifference. This argues for the value of continuing to track foreign assessments of Operation Desert Storm.

\section{Endnotes}

1. Information supplied by U.S. military analyst, April 1993.

2. The French government was one of the few to anticipate publicly the short duration of the war. On January 20 , shortly after the initiation of the air campaign, President Mitterrand said that the war's duration would be "aquestion of weeks." Mitterrand television interview of January 20,1991, in Le Monde, January 22, 1991, cited by David S. Yost, "France and the Gulf War: Political-Military Lessons Leamed," unpublished paper written for the CNSS Foreign Gulf War Lessons Learned Study, May 1992, p. 7.

3. Shahram Chubin, "Iran and the Lessons of the Gulf War 1991," unpublished paper written for CNSS Foreign Gulf War Lessons Leamed Study, November 1991.

4. The quotations are cited by Juan del Aguila, "Cuba's Views of the Gulf War and its Aftermath," unpublished paper written for the CNSS Foreign Gulf War Lessons Learned Study, February 1992.

5. Domico Proenca, Jr., "Brazilian Perceptions of the Persian Gulf War of 1991: An Impressionistic View," unpublished paper written for the CNSS Foreign Gulf War Lessons Learned Study, November 1991, pp. 5-14, 23-24.

6. Written comments by Dr. Ishtiaq Hossain, National University of Singapore, September 16, 1992.

7. James Gow, "Yugoslavia and Lessons from the Gulf War," unpublished paper written for the CNSS Foreign Gulf War Lessons Learned Study, October 1992, p. 8.

8. On this latter point, see Colonel Gordon R. Middleton, USAF, Desert Storm Lessons Learned: Middle Eastern and Asian Perspectives (Maxwell Air Force Base, Alabama: Air War College, Air University, January 1992), p. 6.

9. Davar, February 8, 1991, cited in Reuven Pedhatzur, "Gulf War Lessons Leamed by Israel," unpublished paper written for the CNSS Foreign Gulf War Lessons Leamed Study, January 1992, p. 7.

10. David Earling, "Italy and the Gulf War," unpublished paper written for the CNSS Gulf War Lessons Leamed Study, September 1991, p. 17. 
11. Interview with expert on Iraqi security policy, Los Alamos, NiM, April 1992; interview with expert on Soviet/Russian security policy, Los Alamos, NM, September 1992.

12. Aharon Levran, "Gulf War Lessons - An Israeli Perspective," unpublished paper written for the CNSS Foreign Gulf War Lessons Learned Study, November 1991 , p. 11.

13. Ron Ben Ishai, "Today We have the Ability to Operate Against Missiles Launched from Iraq: An Interview with the Chief of Staff, Lt. Gen. Ehud Barak," Yediot Aharonot, September 29, 1991, cited in Pedhatzur, "Gulf War Lessons Leamed by Israel," p. 6.

14. "Le Ragioni della Vittoria," Rivista Aeronautica, no. 2 (1991), p. 11, cited by Earling, "Italy and the Gulf War, p. 21.

15. Notra Trulock III, The Soviet Military and the GulfWar: A Preliminary Assessment, unpublished briefing, Ccnter for National Security Studies, October 1991.

16. T. Enders and M.J. Inacker, "The Second Gulf War and Germany: Contributions and Political and Military Lessons," unpublished paper written for the CNSS Foreign Gulf War Lessons Leamed Study, October 1991.

17. Air Marshall KD Chadha, VM (Retd), "Air Power Re-Appraised," U.S.I. Journal, January-March 1991. Several South Asian security specialists have emphasized to us that such quotes from individual Indian officers should not be taken to represent the thinking of the Indian military more generally. In fact, these specialists contend that senior Indian military officers tend to be quite unimaginative, especially at the level of doctrine.

18. Earling, "Italy and the Gulf War," p. 18, summarizing Paolo Ferdinando, "La Guerra Elettronicanel Golfo," DifesaOggi (March 1991), p. 107.

19. Levran, "Gulf War Lessons - An Israeli Perspective," p. 43.

20. Yost, "France and the Persian Gulf War," p. 13.
21. Pasquale Bandiera, "AirLand nel Golfo," Informazioni Parlementari Difesa no. 1 (1991),p. 2, cited in Earling, "Italy and the Gulf War," pp. 20-21.

22. See for example, Earling, "Italy and the Gulf War," p. 46.

23. Middleton,DesertStorm Lessons Learned: Middle Eastern and Asian Perspectives, p. 20.

24. There is a debate in among Westem military experts as to how good and how deliberate Iraqi CCD really was, as opposed to how much involved self-inflicted intelligence failures.

25. Pierre Joxe, "Defense et renseignement," Defense Nationale (July 1991), p. 17, cited by Yost, "France and the Gulf War," p. 8.

26. Gow, "Yugoslavia and Lessons from the Gulf War," p. 9.

27. Emanuel Rosen, "Shomron: The Color is Back in His Cheeks," Ma' ariv, 1 February 1991, cited in Pedhatzur, "Gulf War Lessons Learned by Israel," p. 12.

28. Ha' artez, 21 March 1991, cited in ibid.

29. Levran, "Gulf War Lessons - An Israeli Pcrspective," p. 38.

30. Earling, "Italy and the Gulf War," p. 30.

31. Interview with expert on Soviet/Russian sccurity policy, Los Alamos, NM, Septcmber 1992.

32. British Defense White Paper 1992, Lessons from Operation Granby.

33. Enders and Inacker, "The Second Gulf War and Germany," p. 47.

34. Ariel Levite, "The Gulf War: Tentative Military Lessons for Isracl," in Joseph Alpher, ed., War in the Gulf: Implications for Israel (Tel Aviv: Jaffce Center for Strategic Studies, 1992). Scc also Levran, "Gulf War Lessons - An Israeli Perspective," pp. 45-50; and Pcdhatzur, "Gulf War Lessons Learned by Israel," pp. 11 12.

35. Levran, "Gulf War Lessons - An Israeli Perspective," p. 12. Israeli complaints about the performance of the Patriot have received considerable attention in the United States, although the Patriot was never 
intended as an area defense for cities but as a point defense missile. Some of the comments almost certainly have been motivated by concem that U.S. funding for the troubled Arrow program - which has had several failures-might be scrapped by the United States, thus hurting Israeli industry. All Israeli statements about $\mathrm{Pa}$ eriot versus Arrow need to be seen in this light.

36. Baghdad INA, August 11, 1992, citing AL-QADISIYAH, in FBIS-NES-92-115, August 11, 1992, p. 21.

37. Interarma, April 5, 1991, pp. 299-300, cited by Earling, "Italy and the Gulf War," p. 14.

38. Cited in del Aguila, "Cuba's Views of the Gulf War," p. 8.

39. Pedhatzur, "Gulf War Lessons Learned by Israel," p. 14.

40 G.D. Bakshi, "Desert Storm: Application of Air Land Battle Doctrinc," Strategic Analysis (July 1992): 358.

41. Liu Jinglian, "Reflection on the Gulf War and Lessons Drawn from It," unpublished paper written for the CNSS Foreign Gulf War Lessons Leamed Study, December 1991.

42. David Earling, "Italy and the Gulf War," p. 17.

43. This section relies extensively on discussions with Kenneth Pollack, and on Norman Cigar, "Iraq's Strategic Mindset and the Gulf War: Blueprint for Defeat," Journal of Strategic Studies 15 (March 1992): 1 29.

44. Cited by Cigar, "'Iraq's Strategic Mindset and the Gulf War," p. 15

45. Lt. Sanjay J. Singh, "Impact of Technology on Modem Warfare," U.S.I. Journal, (April-June 1991): 173. As noted previously, this assessment is not necessarily that of senior Indian military officers, who tend to down-play the importance of the war.

46. Pierre Joxe, speech to the National Assembly, June 6,1991 , text fumished by the Ministry of Defense, p. 4, cited in Yost, "France and the Gulf War," p. 7.
47. Edith Cresson, speech at the Institut des Hautes Études de Defense Nationale, September 5, 1991, in the Foreign Ministry's Bulletind'Information, September6, 1991, p. 6, cited in ibid., p. 34 .

48. For the definitive essay on this subject, see Notra Trulock, Kerry L. Hines, and Anne D. Kerr, Soviet Military Thought in Transition: Implications for the Long-Term Military Competition, PSR Report No. 1831 (Arlington, VA: Pacific Sierra Research Corporation, May 1988).

49. Notra Trulock III, The Soviet Military and the GulfWar: A Preliminary Assessment.

50. Cited by Jacob Kipp, "The Gulf War, High Technology, and Troop Control: The Nexus Between Military-Political and Military-Technical Aspects of Future War," unpublished paper, U.S. Army Foreign Military Studies Office, May 1992.

51. Cited in ibid. An Indian author made a related point: "In an environment of unequal capability forelectronic warfare [and] unequal radar coverage, air superiority can be achieved even if the combat aircraft of the conflicting parties are, to an extent, of compatible performance." Lt Gen AM Vohra, PVSM IA (Retd), "A Doomed Occupation," U.S.I. Journal (JanuaryMarch 1991): 64.

52. Cited by Kipp, "The Gulf War, High Technology, and Troop Control," pp. 2122.

53. Cited, ibid.

54. Cited, ibid., pp. 16-17.

55. Cited by Stuart Kaufman, "Lessons from the Gulf War and Russian Military Doctrine," unpublished paper, July 1992, p. 34.

56. Cited, ibid., p. 19.

57. Cited, ibid., p. 21.

58. The following is taken from Liu Jinglian, "Reflection on the Gulf War and Lessons Drawn from It," pp. 1-3.

59. Levite, "The Gulf War: Tentative Military Lessons for Israel," p. 218.

60. The U.S. Army is considering a variety of protection systems for its armored vehicles, including the use of a computerized 
sensormeshandexplosive armorthat would determine the size of an incoming kinetic energy round and determine how best to neutralize it. See Vago Muradian, "DoD Probes Smart Tank Armor," Defense News, March 1-7, 1993, pp. 1, 26.

61. Scotty Fisher, “'Mr. Tank' Says Smart Protection will be Fielded Beforc Decade's End," Armed Forces Journal International (July 1992): 21.

62. Levran, "Gulf War Lessons - An Israeli Perspective," pp. 42-43. For its part, the United Kingdom experienced problems with older ground combat vehicles that lacked the speed, survivability and optics to keep pace with the rapid armored advance of more modem systems. British Defense White Paper 1992, Lessons of Operation Granby.

63. Some Indian military experts had anticipated the evolution of warfare along these lines: "Air power then may be expected to play a role well beyond the present "dominant factor' level: in fact signs are already clear that air power wuuld play the leading role in modern wars with the land and naval power playing a role more akin to a support function, albeit a vital one: that of physically holding territory and completing the defeat of hostile forces brought about by the disruption and destruction caused by enemy air powet." Jasjit Singh, "Military Technolcgy' and Intemational Security," Strategic Analysis (Fecember 1987): 1008.

64. Gow, "Yugoslavia and Lessons frum the Gulf War," pn. 9-10.

65. Levran, "Gulf War Lessons - An Israeli Perspective," p. 38.

66. Ephraim Kam, "Gulf WarLessons Leamed by Egypt," unpublished paper written for the CNSS Foreign Gulf War Lessons Leamed Project, March 1992, p. 3.

67. ChristopherIDonnelly, "Evolutionary Problems in the Former Soviet Armed Forces," Survival 34 (Autumn 1992): 39.

68. Cited in Kaufman, "Lessons from the Gulf War and Russian Military Doctrine," p. 18.
69. Cited in Kipp, "The Gulf War, High Technology, and Troop Control," p. 16.

70. Cited in Kaufman, "Lessons from the Gulf War and Russian Military Doctrine," p. 38.

71. Enders and Inacker, "The Second Gulf War and Germany," p. 48.

72. Maj Gen VK Makhod, ASVM (Retd), "Gulf War and the Indian Armed Forces: Some Immediate Lessons," U.S.I. Journal, January-March 1991, p. 67.

73. James Gow, "Yugoslavia andLessons from the Gulf War," p. 11.

74. Ibid., pp. 2-3.

75. Cited in Kaufman, "Lessons from the Gulf War and Russian Military Doctrine," p. 34.

76. Ibid., p. 40.

77. Kam, "Gulf War Lessons Learned by Egypt," p. 17.

78. Levran, "Gulf War Lessons - An Israeli Perspective," p. 41.

79. Kipp, "The Gulf War, High Technology, and Troop Control," p. 32.

80. Ibid., p. 33.

81. Interview with Israeli military specialist, Washington, DC, September 1992.

82. British Defense White Paper 1992, Lessons from Operation Granby.

83. Earling, "Italy and the Gulf War," pp. 35$37,48$.

84. Translated from Julian Garcia Vargas speech to the House Defense Commission, Madrid, April 23, 1991, cited in Luis M. Villanueva, "Spain: The Gulf War Lessons," unpublished paper written for the CNSS Foreign Gulf War Lessons Leamed Study, November 1991, p. 24.

85. Written comments by Dr. Ishtiaq Hossain, National University of Singapore, September 16, 1992.

86. Chubin, "Iran and the Lessons of the Gulf War 1991," p. 33.

87. Telephone interview with Asian security specialist, May 1993.

88. Discussions with Israeli military specialist, Washington, DC, September 1992.

89. Barbara Opall and David Silverberg, "Taiwanese May Soon Coproduce Patriot," 
Defense News, February 22-28, 1993, pp. $1,21$.

90. Telephone interview with Asian security specialist, May 1993.

91. Singh, "Impact of Technology on Modem Warfare," p. 178.

92. Earling, "Italy and the Gulf War," p. 15.

93. Ahmed Hashim, Resurgent Iran: New Defense Thinking and Growing Military Capabilities, paperprepared forthe American Association for the Advancement of Science, August 1992, pp. 11-12.

94. Earling, "Italy and the Gulf War," p. 37.

95. Villanueva, "Spain: The Gulf War Lessons," November 1991, pp. 28-29.

96. Information provided by U.S. military analyst, April 1993.

97. Liu Jinglian, "Reflection on the Gulf War and Lessons Drawn from It," pp. 29-30.

98. Interviews with U.S. government officials, Washington, DC, September 1992.

99. British Defense Whitc Paper 1992, Lessons Leamed from Operation Granby.

100. Earling, "Italy and the Gulf War, pp. 3031.

101. General Jean-Claude Coullon, "Lesleçons do la guerre du Golfe," L'Annee strateqique 1992 (Paris: Dunod, 1992), p. 149, cited in Yost, "France and the Gulf War," p. 70.

102. David Earling, "Italy and the Gulf War," unpublished paper written for the CNSS Foreign Gulf WarLessons Leamed Study, September 1991, pp. 7-10, 48.

103. Dean Cheng, "A Report on East Asian and Naval Lessons from the Gulf War," unpublished paper written for the CNSS Foreign Gulf WarLessons Learned Study, February 1993, pp. 7-9.

104. Villanueva, "Spain: The Gulf War Lessons," pp. 25-31.

105. This section is based substantially on Yost, "France and the Gulf War," and on conversations with Robbin Laird.

106. Yost, "France and the Gulf War," p. 3.

107. Mitterrand, speech at the Ecole Superieure de Guerre, April 11, 1991, text provided by the Presidence de la Republique, p. 7 . cited in ibid., p. 32.
108. Pierre Joxe, speech to the National Assembly, June 6, 1991, text provided by the Ministry of Defense, pp. 10-11, cited in ibid., p. 33.

109. It is useful to contrast the relatively favorable official British assessment of their performance in the Gulf with the downbeat French self-assessment: "The underlying flexibility of our armed forces, the balance of their capabilities and their ability to undertake joint operations were fundamental to success. The shortcomings identified were not such as to compromise the value of our contribution to the operation; many had been identified before the crisis and provision had been made in the forward programme. . . . Some adjustments will be made as a result of Operation GRANBY but no requirement was identified that demands a major change in direction." British Defense White Paper 1992, Lessons Learned from Operation GRANBY.

110. Giovanni de Briganti, "WEU's Satellite System May Fly in 2000," Defense News, February 1-7, 1993, pp. 4, 29.

111. Roland Dumas interview in Journal Du Dimanche, February 10, 1991, cited in Yost, "France and the Gulf War," p. 56.

112. Lawrence Freedman, "Gulf War Lessons Leamed by Foreign Countries: Britain," unpublished paper written for the CNSS Foreign Gulf WarLessons Learned Study, October 1991, p. 16.

113. Enders and Inacker, "The Second Gulf War and Germany: Contributions and Political and Military Lessons." This section is based substantially on the EndersInacker paper.

114. Interview with U.S. government officials, December 1992.

115. Testimony of CIA Director R. James Woolsey before the Senate Governmental Activities Committee, February 24, 1993, Federal News Service Transcript, p. 9.

116. Singh, "Impact of Technology on Modem Warfare," pp. 180,186.

117. Brig RD Law (ret), "The Gulf War: The Last Hundred Hours: Lessons for the 
Indian Mechanized Forces," The Journal of the United Services Institution of India, July-September 1991, pp. 357, 361-62.

118. This section is based substantially on Karl S. Gashler, "China and the Gulf War: The Military Technical Lessons," unpublished paper written for the CNSS Foreign Gulf WarLessons Leamed Study, August 1992; Ellis Joffe, "China after the Gulf War: The Lessons Leamed," unpublished paperwritten for the CNSS Foreign Gulf War Lessons Learned Study, November 1991; and Liu Jinglian, "Reflections on the Gulf War and Lessons Drawn from It," unpublished paper written for the CNSS Foreign Gulf War Lessons Leamed Study, December 1991. The section also benefited from discussions with Gerrit Gong, Harry Harding, Paul Godwin, Jonathan Pollack, and various U.S. government officials.

119. To deter or respond to a major military threat to China's sovereignty-a highly unlikely eventuality for at least the next decade - the Chinese would revert to a strategy based on nuclear deterrence, and conventional strategy and operations designed to impose high costs on the aggressor. Such an eventuality is receiving considerably less attention by the PLA, given the changing strategic conditions.

120. The fact that Chinese equipment was used in the Iraqi raid against Khafji was a source of cmbarrassment to the PLA, since the raiding force was obviously regarded by the Iraqis as inferior and expendable.

121. Interview with U.S. government official, June 1993.

122. Academy of Military Science, "Lessons Leamed from Air Attack and Air Defense Operations in the Gulf War," from the book Gulf War (Beijing: July 1991), as reported in "Gulf War, an AMS Publication," U.S. Defense Liaison Office, Hong Kong, July 1, 1991, Document No. 68420229 (unclassified), p. 3. Hereinafter referred to as Summary of AMS Study, with appropriate article reference.

123. Liao Zhiyong, "New High Technology Poses Challenge to People's Air Defense,"
Jiefangjun Bao, October 25, 1991, FBISCHI (November 21, 1991): 33.

124. Cited in Gashler, "China and the Gulf War," p. 7.

125. Summary of AMS Study, "Developmental Trends in Army Building as Seen from the Gulf War," pp. 3-4.

126. Ibid., p. 3.

127. Summary of AMS Study, "Gulf War Enlightens Army Building," p. 3.

128. Dong Wenxian, "Preliminary Study of Modern Territorial Air Defense," Jiefangjuin Bao, September6, 1991, FBISCHI (October 7, 1991): 4.

129. This section is based substantially on Pedhatzur, "Gulf War Lessons Leamed by Isracl," and Levran, "Gulf War Lessons-An Israeli Perspective."

130. Intervicw with U.S. government official, Washington, DC, September 1992.

131. The following discussion is largely taken from Michael Eisenstadt, Arming for Peace? Syria's Elusive Quest for Strategic Parity (Washington, DC: The Washington Institute for NearEast Policy, 1992), pp. 94-96.

132. Ariel Levite, "The Gulf War: Tentative Military Lessons for Isracl," p. 197.

133. Ma' ariv, December 25, 1990 , cited in Pedhatzur, "Gulf War Lessons Leamed by Israel," p. 19.

134. Levite, "The Gulf War: Tentative Military Lessons for Israel," pp. 210-11.

135. Barbara Opall, "U.S., Israeli Officials Strive to Revive Interceptor," Defense News, February 22-28, 1993, pp. 3, 20.

136. "Arens Says War Proved Need for Targeting Mobile Missiles," Aviation Week \& Space Technology (June 24, 1991): 26.

137. Reported in Aviation Week \& Space Technology (February 15, 1993): 13.

138. The following assessment is drawn largely from Ephraim Kam, "Gulf War Lessons Learned by Egypt," unpublished paper written for the CNSS Foreign Gulf War Lessons Leamed Study, March 1992.

139. The limits on actual Egyptian procurement were stressed in discussions with U.S. govemment officials, Washington, 
DC, May 1992, and in comments on an earlicr draft by Michael Dunn, January 1993.

140. The following assessment is drawn largely from Young Koo Cha, "Korean Assessment of the Gulf War Lessons," unpublished paper, September 1991, pp. 14-20; and from Cheng, "A Report on East Asian and Naval Lessons from the Gulf War," pp. 16-20.

141. Young Koo Cha, "Korean Assessment of the Gulf War Lessons," p. 14-15.

142. Cheng, "A Report on East Asian and Naval Lessons from the Gulf War," p. 20.

143. See, for example, Yong-won Yu, "Comparisons of North and Suuth Korea's Air Power," Wolgan Choson (March 1991), pp. 378-91, in FBIS-EAS-91-088 (May 7, 1991), pp. 15-23.

144. Chong-chang U, "Korean AirForce Moves to Purchase Tomado Aircraft for Electronic Warfare," Chugan Choson (March 24, 1921), pp. 58-62, in FBIS-EAS-91-60 (March 28, 1991), p. 34.

145. Alberto R. Coll, "America as the Grand Facilitator," Foreign Policy no. 87 (Summer 1992): 51.

146. This point was made to the author by Steven R. David.

147. Middleton,DesertStormLessons Learned: Middle Eastern and Asian Perspectives, p. 18.

148. James Gow,"Yugoslavia and Lessons from the Gulf War," unpublished paper written for the CNSS Forcign Gulf War Lessons Learned Study, October 1992, pp. 10-11.

149. The Joint Staff, 1992 Joint Military Net Assessment (Washington, DC: The Pentagon, August 1992), p. 11-8.

150. Domico Proenca, Jr., "Brazilian Perceptions of the Persian Gulf War of 1991: An Impressionistic View," unpublished paper written for the CNSS Forcign Gulf War Lessons Leamed Study, November 1991.

151. The following discussion is based on a telephone interview with a specialist on Central and East Europcan security, November 1992.
152. Cited in Juan del Aguila, "Cuba's Views of the Gulf War and its Aftermath," unpublished paper written for the CNSS Foreign Gulf War Lessons Leamed Study, February 1992, p. 22.

153. Citcd in ibid., p. 27.

154. Ibid.

155. This section is based substantially on discussions with Notra Trulock III, Jacob Kipp, and Stephen Meyer, September-October 1992.

156. Jacob Kipp, "The Gulf War, High Technology, and Troop Control: The Nexus Between Military-Political and MilitaryTechnical Aspects of Future War," unpublished paper, U.S. Army Foreign Military Studies Office, May 1992.

157. Cited by Stuart Kaufman, "Lessons from the Gulf War and Russian Military Doctrine," p. 35

158. This section relies extensively on discussions with Kenneth Pollack, and on Norman Cigar, "Iraq's Strategic Mindset and the Gulf War: Blueprint for Defeat," Journal of Strategic Studies 15 (March 1992): 129.

159. Testimony of R. James Woolsey, February 24, 1993.

160. This section is based in part on William $J$. Taylor, Jr. and Michael J. Mazarr, "North Korea and the Gulf War: Pyongyang's Lessons Leamed,"unpublished paperwritten for the CNSS Foreign Gulf War Lessons Learned Study, November 1991.

161. This quote was cited at a CNSS Workshop on Asian and Pacific Gulf War Lessons Learned, Washington, DC, February 12, 1992. The North Koreans have long emphasized troop morale by indoctrinating their forces to defend against the advances and imperialism and to liberate their southem brothers. For a summary of this workshop, see Gerrit Gong, Lessons Learned from the Persian Gulf War: Asian Perspectives, Report of a CNSS Workshop (Los Alamos, NM: Center for National Security Studies, Los Alamos National Laboratory, August 1992). 
162. Interview with American expert on Asian security, Washington, DC, June 1993.

163. Telephone interview with Asian security specialist, May 1993.

164. Telephone interview with Asian security specialist, May 1993.

165. Testimony of R. James Woolsey, February 24, 1993.

166. Joseph S. Bermudez, Jr., "North Korea's Intelligence Agencies and Infiltration Operations," Jane' Intelligence Review (Junc 1991): 269-77.

167. Telephone interview with security specialist on Asia, February 1993.

168. Telephone interview with Asian security specialist, May 1993.

169. Testimony of R. James Woolsey, February 24, 1993.

170. This section is based substantially on Ahmed Hashim "Resurgent Iran: New Defense Thinking and Growing Military Capabilities," unpublished paperprepared for the American Association for the Advancement of Science, August 1992; Shahram Chubin, "Iran and the Lessons of the Gulf War 1991," unpublished paper written for CNSS Foreign Gulf War Lessons Leamed Stuciy, November 1991; Robent Swartz, ed., GulfWar Lessons Learned: Middle East Perspectives, Report of a CNSS Workshop (Los Alamos, NM: Center for National Security Studies, Los Alamos National Laboratory, July 1992); James P. Thomas, "Iranian Military Lessons Learned from the Gulf War," unpublished paper written for the CNSS Foreign Gulf War Lessons Learned Study, August 1992; and written comments on a draft of this study by Michael Dunn.

171. Written comments by Shahram Chubin, June 1993.
172. "A Military Lesson from the Persian Gulf War," Keyhan International, March 17, 1991, in FBIS-NES, March 25, 1991, p. 63.

173. Ibid. The key for Iran "is to take the necessary measures to build up its own short, medium, and long-range surface-tosurface as well as surface-to-air missiles. The Iranian military planners must take this big lesson from the Persian Gulf war and urgently work on new missile projects in order to boost the defense capabilities of the country and minimize possible enemy air and missile strikes against Iran's vital economic centers as well as military forces."

174. Interview with Middle Eastem expert, Washington, DC, December 1992.

175. Interview with Middle Eastem expert, Washington, DC, December 1992.

176. Testimony by R. James Woolsey, February $24,1993$.

177. Banks and Bruce, "Iran Builds Its Strength," p. 158.

178. Interview with Middle East expert, Washington, DC, December 1992.

179. According to Shahram Chubin, the Kiloclass submarines were ordered in June 1989, with the intention of of fsetting Iraq's planned acquisition of frigates from Italy. By the time that the submarines were to be delivered, however, the strategic situation in the Persian Gulf-and hence the importance of the submarines - had changed dramatically. Written comment by Chubin, June 1993.

180. James P. Thomas, "Iranian Military Lessons Learned from the Gulf War," p. 8.

181. Tehran INRA in English, April 29, 1992, in FBIS-NES, April 30, 1992, p. 2. 


\section{Analysis and Conclusions}

To sum up: the Gulf War (still) matters. The Gulf War, properly understood, remains an important source of political-military and military-technical insight formany key foreign states.

To bc sure, the unique attributes of the Gulf Warare widely appreciated: unmistakable Iraqi aggression; oil; an emerging nuclear threat; the residual Cold War capabilities and relationships that strengthened the military coalition; the conflucnce of great-power interests on the UN Security Council; and the like. Foreign observers also recognize that much water has passed under the bridge since Operation Desert Storm-including the collapse of the Soviet Union and a series of crises and conflicts associated with the former Yugoslavia - that could negate or at least qualify some of the initial lessons from the Gulf. The electoral defeat of President Bush is another development that tends to put more distance between the Gulf War and current events. Pcrceptions of the meaning of the Gulf War have in some cases undergone significant changes due to internal and extemal circumstances.

All this said, the Gulf War nevertheless seems to remain an extremely useful, although by no means definitive, perspective from which to assess foreign perspectives on future political and military trends. The Gulf War is a critical data point; it was the first major intemational event involving military power after the end of the Cold War, and it remains the event against which subsequent political-military and military-technical developments tend to be measured. The war revealcd or confirmed to many foreign states certain facts and trends in the emerging international cnvironment; these states are adjusting their policics and interests to con- form to, or take advantage of, these facts and trends. The war also revealed or confirmed important tensions and contradictions in national views about the Gulf War and the future of intemational relations. Finally, the war, and its outcome, is by no means viewed as a conclusive image of the future; much remains unknown.

The body of the report has dealt with how foreign nations perceive these facts, trends, contradictions, and unknowns. This section addresses the overall impact of foreign reactions to the Gulf War, and attempts to identify a number of critical issues that American decision makers may have to address over the next several years.

\section{"So Whats"}

This report on foreign perceptions of the Gulf War has becn organized around three central messages: the U.S. matters; military power matters; and technology matters. This section will try to identify some critical policy implications and uncertainties that flow out of these central messages ("so what"). Not all of these implications are necessarily consistent, norneed to be acted upon, but policy makers should be aware of the decisions and issues that they face, given forcign reactions to the Gulf War (and other intemational events).

America as World Leader. Policy makers must appreciate the importance that otherstates, friendly, hostile, and nonaligned, continue to place on the United States as the organizing force in international relations. Two years after the Gulf War, foreign states tend to evaluate 
U.S. capabilities more highly than do many American elites. The passage of time, the events in Yugoslavia, and domestic political factors have tended towards a discounting by Americans, perhaps prematurely, of the Gulf War's importance as an expositor of U.S. capabilities across the board. The United States has tended to focus on its relative inability to act (in Yugoslavia) rather than the strength of its position (in the Gulf War).

What is much less certain to foreign observers is whether, how, and for what purpose the United States will apply its power in the postCold War, post-Gulf world. The emerging short-term challenge for American policy makers is to demonstrate to foreign observers that U.S. power will continue to be applied purposefully and effectively to achieve American and international objectives. For the longer term, the United States will have to address three areas if it is to retain its central and unique position in the intemational system. The first is economic and technological competitiveness. The fact that the United States had to seek major international funding for the Gulf War made a serious, and negative, impression about U.S. economic weakness that must be addressed. The second is military power. Any sense that the United States could not perform a Desert Storm in five to ten years due to military retrenchment would remove an essential pillar of American diplomatic influence and encourage or impel other powers, major and lesser, to try to fill the vacuum. The last area of importance is intemational legitimacy. As a legacy of its successful leadership during the Cold War, the United States enjoys a level of global prestige that goes beyond its economic and military strength and that allows it to guide the international community on issues Washington regards as vital. This prestige is not automatic; it ultimately depends on a sense that American leadership is legitimate because it stands for something beyond the narrow national interest. Such legitimacy is essential to deal with international fears about U.S. activism as well as speculation about potential American decline.

Defining the Future of the International System. Despite the demonstration of U.S. power in the Gulf War, there is an underiying sense that the emerging post-Cold War environment is neither unipolar nor multipolar, and hence the current patterns of international behavior may be transitional rather than enduring. The length of this transitional period is generally put at five to ten years among those foreign observers who are inclined to speculate. For the most part, the current policies of most foreign governments are not now being determined by long-term expectations about character of that future environment, but by the exigencies of the moment. There are nevertheless important minority views about imminent orinevitable American decline-and the rise of challengers to American leadership-that could come to the forefront depending on U.S. actions and/or domestic political changes.

It is critical for the United States to shape expectations about the long-term strategic environment and the kinds of security arrangements that will be appropriate to that environment. The U.S. performance in Operation Desert Shicld/Storm has played a role in shaping those expectations, but the Culf War afterglow will have a finite half-life. American policy makers should be aware that their actions in the former Yugoslavia and Somalia are becoming part of a pattern of intemational peacemaking and peacekeeping, which will be at the heart of whatever new world order, or disorder, finally emerges. This pattern is being observed by foreign powers who wish the United States well, or ill, for clues about how they should behave in future crises closer to home.

Over the longer term, the structure of the intemational system will depend on how the Unitcd States accommodates other centers of power that were marginalized in the Gulf crisis but that will inevitably seek, in one form or another, their place in the sun (Germany, Japan, Russia if it remains intact, and China). As suggested below, the impetus for any changes in the current transitional pattern may have to come from the United States, since these other power centers are now quite limited in how far and how fast they themselves can push the issue. If the United States fails to do so, it runs the risk that the issue of rising powers will emerge under 
unfavorable circumstances-and that these power centers will as a result define themselves in opposition to, rather than as satisfied partners in, an international system that is initially crafted by the United States.

The German and Japanese Question. There is a tension between the growing economic power and potential political ambitions of Germany and Japan, on the one hand, and the domestic willingness of these states to develop policies and tools to pursue those ambitions, on the other. The resolution of this tension will largely determine how the hierarchy of great powers emerges over the longer term (decade plus), because Japan and Germany/Europe are the most likely aspirants to great-power status in this time frame.

A "realistic" perspective among the current Japanese and German goveming elites points toward assuming true great-power status. The Gulf War highlighted or reinforced the view among these German and Japanese elites that greater international activism will be necessary to allow them to have a greater say in international relations. This influence, in tum, will require the development of strategic instruments, including tailored military capabilities of some sort. At the same timc, the Gulf War indicated a complete lack of political consensus in Germany and Japan about future directions in national security policy. There is an obvious and deeply ingrained societal reluctance to be anything other than inward-looking states that focus on economic concems. Many serious analysts of Germany contend that the new Germany is most likely to become, if not a big Switzerland, then a big Italy, in terms of its lack of ability to formulate strong and consistent international positions.

Even if the governing elites in Germany and Japan seek quietly to devclop more capable strategic means, either independently or part of a multinational organization, probable funding constraints on the Japanese and German defense ministries will delay, if not preclude, the development of desired autonomous military capabilities. But events may force a decision more rapidly than we now expect. The emergence of a nuclear-armed North Korea and the acknowledged proliferation of nuclear weapons into Ukraine and Eastem Europe, coupled with the loosening of security ties with the United States, for example, could lead to a major change in German and Japanese security policy. Rather than become a hostage to such events, the United States should anticipate that Berlin and Tokyo will eventually become more activist over time, and try to encourage and support that activism where appropriate (as Washington did in the manner of German unification).

The Challenge to Regional Security Order. The emergence of Japan and Germany/Europe as truly global powers, whether desirable or not, is some distance off. The United States will be the only true superpower for some time. But Washington lacks the capability, and probably the interest, to be the principal player in each and every crisis below the "global" level (however that level is defined). How, then, will security be maintained at the regional or subregional level?

In the aftermath of the Gulf War, there was a clear interest of many in Europe, Asia, and the Middle East to strike a new division of labor with the United States-one in which a new hierarchy of regional powers would supplement U.S. global power. This would point toward a devolution of the current international system (which is neither unipolar nor multipolar) into a series of subsystems, whose security would be guaranteed to a first order by one or more regional powers or organizations. In such a system, the United States might still act as the ultimate guarantor of regional security if all else failed, and as the leading power conceming "global" security issues. The United States could also in principle provide certain types of military infrastructure-e.g., command and control, reconnaissance, transportation, and ballistic missile defense-that would enable foreign militaries to use their ground, naval, and air forces more effectively in regional operations without having to invest independently in these very expensive capabilities. Such a division of labor would run against the grain of greater military autonomy that nations such as 
Israel, France, and South Korea have been seeking, but that they may not be able to obtain because of cost considerations.

Although such a division of labor makes sense in principlc, there are highly uncertain and contentious boundaries between "regional" and "global" security issues that have yet to be worked out, and that may not ultimately be resolvable.

The Gulf War and its outcome indicated that the Middle East, and particularly the Persian Gulf, is a region to which this division-of-labor model will not immediately apply. The key proWestem players in the Gulf are not willing to accept a regionally based security system based on Egyptian and Syrian military power, or to include Iran or Iraq. Maintaining the balance of regional power requires credible American guarantees, if not a direct American presence.

The Yugoslav crises also raise serious questions whether a European-based regional security order is possible. The CSCE was never a serious player once fighting broke out. The failure of the European Community to resolve the crises in their early stage-to successfully orchestrate an economic, political, and military coalition such as the U.S. organized against Iraq-seemed to indicate that American leadership is still an essential element in European regional security. At the same time, the principal vehicle of American power on the continent-NATO_likewise has proved essentially irrelevant to date in Yugoslavia. There is a very real question about whether and how such a vacuum can be filled in Europe.

The Future of the United Nations. As a consequence of the lack of good regional security alternatives, the Gulf War and Yugoslavia suggest the importance of the United Nations as the means through which multinational action can be taken. But there are real problems on the horizon for the UN as well. It is not at all certain that the Russian Federation (if it remains intact) and China will continue to support the actions of the other current permanent members of the Security Council. The ambitions of Germany and Japan to become permanent members of the Security Council, so as to be able to take part in the decision-making process on issues such as the Gulf crisis, will complicate matters. It is not clear that thcir interest in membership will be supported (c.g., China vetoing Japanese membership), creating obvious political tensions among the major powers. Even if Japan and Germany do become Security Council members, it is not clear that their interests will coincide with those of the others (again, a Chinese-Japanese rivalry could emerge, at least over issues relating to Asia). Pressures will grow to allow second-tier powers to become Security Council members (Brazil, India, and Nigeria most often mentioned).

This combination of pressures and circumstances suggests that the United States cannot expect to rely on the United Nations as the principal security mechanism for all global and regional crises. If Security Council membership is expanded, the UN may become gridlocked; but if membership is not changed to reflect changing geopolitical and geoeconomic conditions, the Council may lose its legitimacy. Innovative procedural solutions could resolve this problem in some sense, but they cannot generate consensus where the interests of the major powers do not coincide. This is not to say that Washington should abandon the United Nations as an instrument of national policy and international security to be employed wherever possible. Rather, American policy makers should be realistic about the probable constraints on the UN that may begin to emerge. They should also focus on developing a consensus with those states that do matter in any particular case, and recognize that there may be occasions when desired American policies are overtly opposed by other major powers.

The Role of Non-Western Powers. Many non-Westem states are concerned with how they might fit peacefully and prosperously into the emerging global and/or regional politicaleconomic-military system(s). The Gulf War suggested real problems for such states in the emerging security environment, whatever its contours might be. The enormous military gap with the West revealed by the Gulf War is worrisome to them, as is the lack of societal 
cohesion and modern industrial-technical infrastructure. Some non-Westem states argue that export controls, nonproliferation regimes, and the like are efforts by the advanced powers (particularly the United States) to ensure that the gap between the have and have-not states is maintained. There is of course nothing new in this argument, but there is a sense that an important U.S. lesson learned from the Gulf was the heightened need to keep non-Western states and cultures "down." The U.N. sanction/inspection regime imposed on Iraq as a consequence of the Gulf crisis/war is seen as a highly disquieting preview of the future in this respect.

All this will incline non-Westem powers to find means to break the economic and military monopoly of the West, and particularly the United States. This inclination could well coincide with efforts by some Westem powers to weaken American power and influence for their own purposes. In short, U.S. policy makers should be sensitive to the fact that the makings of an anti-U.S. coalition are present, if yet unformed, and that steps to dissuade the emergence of that coalition may be necessary.

Internal vs International Rights. The aftermath of the Gulf War (and more recently the Yugoslav crises) have incrcascd international awareness of the ethnic, rcligious, and tribal pressures that will exist in the post-Cold War world. The Gulf War also signaled that the international community may well take an interest in the "intemal" affairs of states, especially if those affairs have broader political or economic implications. For many states, or factions within states, their policies must therefore be fundamentally shaped by the necessity to encourage, or avoid, intcrnational intervention in "intermal" affairs.

The United States is having great difficulty in formulating policies that are appropriate to particular intra-state conflicts. The key here is as likely to be the state of U.S. public opinion as the conditions in any given crisis. American policy makers have to date been pulled in different directions by public opinion-to intervene to stop atrocities, and to stay out to avoid becoming bogged down in other people's wars.
This suggests that the new administration may want to get out ahead of events and try to shape opinion on the degree and circumstances of American intervention, rather than continue to react. To be sure, the proclamation of doctrines can be dangerous; they can mislead friends and potential adversaries and reduce valuable room for diplomatic maneuver. Still, a de facto doctrine is likely to emerge over time in any case, and it may behoove the administration to put its own stamp on public expectations as soon as possible.

Nuclear Weapons. The Gulf War signaled the emergence of a potentially significant asymmetry of views concerning the future role and importance of nuclear weapons. The advanced military powers, notably the United States, Britain, and France (and indirectly the nonnuclear powers, Germany and Japan) have made strong efforts to separate their nuclear capabilities from regional conflict contingencies. The Gulf War indicated that the advanced military powens believe that they enjoy such conventional superiority over regional rivalries in high-intensity warfare that there is no need to play the nuclear card. These states indicated that if Saddam had used weapons of mass destruction (i.e., chemical or biological) during the Gulf War, theirpreferred method of retaliation would have been conventional in character.

On the other hand, for states that are on the wrong side of the military-technical gap and that have reason to be concemed with a U.S.-led intervention, nuclear wcapons appear to be an increasingly attractive means of offsetting that gap and deterring intervention. This is true for Russia (and possibly China), as well as the Irans and Iraqs of the world. The preferred method of the advanced military powers to deal with this asymmetry will be primarily political in character-e.g. , tightened export controls and reassurance through measures among themselves such as a nucleartest ban-coupled with the threat of conventional preemption of nuclear facilities. But thought should also be given to circumstances in which a hostile regional power has obtained nuclear weapons. This hostile power may not share Western ideas of deterrence- 
which is not to say that it cannot be deterred, but that American policy makers must understand the very different strategic dynamics that this situation could create.

In such a situation, Washington itself will obviously be concemed with the need to avoid being deterred by a nuclear-armed hostile regime from taking actions that otherwise would be in the vital interests of the United States. But there are other issues as well. For examplc, during a crisis or conflict, the nuclear command and control arrangements of the regional power may not be stable or secure. Internal conflicts may place the weapons in jeopardy. Other nations may inject themselves into the situation to protect their perceived interests, and so on.

The Future of Warfare. The Gulf War did not necessarily signal a revolution in military affairs, but it will lead to, or reinforce, national military "trajectories" that could result in significant changes in future defense concepts, force structure, doctrine, and tactics. The United States now enjoys a unique global military capability that is unlikely to be challenged for perhaps the next five to ten years. But that does not mean that the United States is omnipotent always and everywhere. The war with Iraq demonstrated that American forces perform superbly in the desert-but can they do as well in mountains, jungles, or urban areas? At some point, a hostile regional power may intentionally or inadvertently test U.S. capabilities under these more difficult circumstances. If the United States performs less than adequately, this would offset much of the prestige that the American military gained in Operation Desert Storm.

The Gulf War will in any case be a central reference point for any regional military that desires to move up to another level of technological capability, especially if it seeks to meet an advanced military power on more equal terms. Foreign militaries can thus be expected to continue the "lessons learned" process for some time, perhaps after a period of apparent indifference. This argues for the value of continuing to track foreign assessments of Operation Desert Storm. Looking into the first decade of the next century, American policy makers should be aware of indications that regional powers, perhaps allied with more advanced states, might seek to develop high-technology/ leading edg:-forces with the aim of challenging American interests across a range of contingencies.

In some cases, these highly-capable units could supplement regular standing armies, perhaps as special operations strike forces. However, like contemporary stand-off weapons, such forces may become the symbols of a country's rapid-response ability to control strategic situations ("arriving first with the most"). Not only budget and manpower efficient, these forces will conform to modern trends by emphasizing mobility and maneuver, and not necessarily overwhelming mass. The ability to produce and dcliver nuclear, chemical, and biological weapons could become much more sophisticated and militarily effective. Hostile regional military powers can be expected eventually to go beyond low-tcchnology countermeasures and attempt to devise means to strike directly at the U.S. military centers of gravity - command and control, logistics, and joint operations. Countersocictal tactics might also emerge: human and computcr viruses; economic disruption through disabling key networks; and environmental warfarc.

These speculations may seem far fetched, but they are intended to reinforce one of the central theses of this report: regional powers learned a good dcal from the Gulf War, but they do not expect or intend that the war will define their future. Regional powers are understandably working to accommodate or work around the Gulf War experience so that they will be in a better position to deal with future crises and conflicts. The U.S. performance in Operation Desert Shield/Storm has played a major role in shaping the expectations of regional powers, but the Gulf War afterglow will have a finitc half-life.

\section{Was the Gulf War a Watershed?}

In the immediate aftermath of the Operation Desert Storm, there was a widespread perception that the experience might be the defining 
event of what President Bush called the New World Order. One of the questions that our authors implicitly addressed was whether this perception would prove to be enduring. The preliminary, and general, answer is: No, the Gulf War did not seem fundamentally to change the overall direction of intemational politics. That is, it did not lead most nations to adopt policies in an order-of magnitude different direction from that which they would have followed had Iraq not invaded Kuwait (absent the success of Operation Desert Shield/Storm). By contrast, the end of the Cold War and the disintegration of the Soviet Union, taken as a whole, did constitute such a watershed.

There are a number of important exceptions to the general conclusion that the Gulf Wardid not represent a defining moment in intemational relations. These are noted throughout the report. But as a rule, the Gulf War seems to have served more as a catalyst and an agent of confirmation than as a watershed. It illuminated many of the key trends and essential elements of the new strategic environment, even if the war itself did not lead to a new world order.

- The Gulf War was a catalyst in the sense that the war brought to the forefront trends, issues and decisions that were probably going to emerge anyway-everything else being equal - but the warmade them visible sooner and more pointedly than might otherwise have been the case.

- The war served as an agent of confirmation in the sense that the war and its outcome served to reinforce national views and policies that were already widely held, or to strengthen (or challenge) particular arguments that were being presented in national debates over the future. Many foreign Gulf
Warlessons learned thus concerned matters of degree-faster or slower, more or lessrather than matters of kind.

This said, it is also too early to say definitively that the Gulf War was not a watershed. Subsequent events could change our perception of the character and importance of the Gulf War. For example, our view of the Gulf War would dramatically change if a number of key proWestem Arab regimes are overthrown by Muslim fundamentalists whose success is attributed to popular revulsion against those regimes that supported the U.S. in the Gulf.

Finally, it is important to note that a failure of U.S. policy in the Gulf probably would have been a watershed. A political or military failure by Washington against Saddam Hussein would have gone against general expectations and would have forced many nations to rethink their basic interests. The United States might well have been seen as a markedly declining power, regional aggression could have appeared to be a much more attractive option; energy prices might have soared; the internal dynamics in the Soviet Union could have evolved in a significantly fashion; military contributors to the coalition might well have blamed the financial contributors, and visa versa, leading to a spiral of tension and conflict among the great powers; and so on.

In any case the importance of this catalytic and confirmatory role should not be minimized because the lessons of the Gulf War have become and will continue to be a common "currency" that mediates the exchange through which many policy decisions by key states are made. For most nations, the Gulf War was not thought to be irrelevant, although its unique features were appreciated. It had an impact, and continues to do so, and is therefore worthy of study. 


\section{Appendix \\ Study Outline: \\ Gulf War Lessons Learned by Foreign Nations}

Each participant in the study was asked to address four general areas with respect to their assigned nation. These areas are described below. The study participants were to use these areas as guidance for preparing their report; they were intended to be neither exhaustive nor definitive. The participants were directed above all to seek to understand the lessons leamed by their assigned nation from the perspective of that nation, and not to generate answers to predetermined questions that were not necessarily relevant in all cases. Also, because the military and political leaderships in most countries are not monolithic, the study participants were asked to note any important disagreement or debates.

\section{Objective Analysis by Foreign Nations of} the Course and Outcome of the Persian Gulf Conflict.

- From the perspective of the nation under study, how did the United States and the coalition win the war? What factors were critical-e.g., technology, leadership, the command structure, operational concepts, logistics?

- How did the actual U.S. performance in the warcompare with expectations about American military capabilities prior to and during the crisis? And in specific terms, how well were Westem military technologies seen to perform (primarily U.S., but also British and French)? Were there any perceived military weaknesses or failures on the part of the United States?
- If the nation being studied was involved in the Gulf conflict, how does it assess the performance of its own military forces? How did this performance compare with its prewar expectations? Did it suffer from any military weaknesses or failures? If this nation has a regional military adversary that took part in the Gulf War, how well did this adversary seem to perform?

- How did Iraq lose the war? Did Iraq successfully demonstrate any military capabilities that actually (or potentially could have) caused serious problems forthe United States?

\section{Incorporating Political-Military Lessons} Learned.

- How will the course and outcome of the Persian Gulf War affect this nation's view of the character of international relations in the future? Have its major perceived interests and policies changed as a consequence of the Gulf War experience?

- What lessons about crises and crisis management did this nation take away from the July 1990-January 1991 period?

- Have this nation's perceptions of the utility of military power and the use of force changed? Does international conflict seem more or less likely? Will this nation bchave differently in future international crises because of its views of and experience in the Gulf War?

- Has this nation's perception of the United States changed significantly? What mole did 
domestic American politics play in the U.S. conduct of the war?

3. Incorporating Military-Technical Lessons Learned.

- How will the course and outcome of the Persian Gulf war affect this nation's view of its armed forces, including the command system, force structure, doctrinc, and technology? Did the Gulf War reveal a comparative advantage/serious weaknessinone or more of these areas? What adjustments might be made to utilize this advantage (or cover up weaknesses)?

- How does this nation now evaluate its own military capabilities relative to those of potential adversaries?

- In light of the Gulf War, are there areas of warfare and technology that now seem to be much more important-e.g., space, mobile ballistic missiles and BMD, PGMs, air defense, electronic countermeasures? Is this nation interested in, and capable of, moving into any of these areas to a greater extent than at present?

- Docs this nation see any relatively easy way to nullify U.S. advantages as displayed in the Gulf War?

\section{Assessing the United States.}

- How does this nation expect the United States to react to the Gulf War-that is, what political, military, and technical "lessons leamed" does this nation see Washington taking away from Operation Desert Shield/Storm?

Does this nation understand the Vietnam Syndrome in the United States? Does it believe that this syndrome has been exorcised by the Gulf War?

- Will this nation attempt to influence/deccive the United States with respect to how it will respond to the experience of the Gulf War? 


\begin{abstract}
This report is a synthesis of studies done by regional experts on how nations besides the United States reacted to the Persian Gulf War. A unanimous conclusion of the country studies was that the Gulf War demonstrated the United States is the only superpower in the world today. American power was not lirnited to the military realm: from toreign perspectives the United States demonstrated the aillity and willingness to exercise global political leadership. A unique U.S. attribute in the Gulf War was its sbility to be an integrator of nations and policies. This was in contrast to thrs international and domestic weaknesses of Germany and Japan, the two nations widely seen as emerging contenders for global status in a new, economically dominant world. Foreign obseivers noted, however, American weaknesses, particularly economic. There has been some rethinking and downgrading of American power since the Gulf War by foreign observers, but the United States is still regarded as the sole superpower-in short, the United States still matters.
\end{abstract}

\title{
DISCLAIMER
}

This report was prepared as an account of work sponsored by an agency of the United States Government. Neither The Regents of the University of California, the United States Government nor any agency thereof, nor any of their employees, makes any warranty, express or implied, or assumes any legal liability or responsibility for the accuracy, completeness, or usefulness of any information, apparatus, product, or process disclosed, or represents that its use would not infringe privately owned rights. Reference herein to any specific commercial product, process, or service by trade name, trademark, manufacturer, or othenvise, does not necessarily constitute or imply its endorsement, recommendation, or favoring by The Regents of the University of California, the United States Govr znment or any agency thereof. The views and opinions of authors expressed herein do not necessarily state or reflect those of The Regents of the University of California, the United States Government or any agency thereot.

This report has been reproduced directly from the best available copy.

It is availasle to DOE and DOE contractors from the Office of Scientific and Technical Information.

P.O. Box 62 ,

Oak Ridge, TN 37831.

Prices are available from

(615) 576-8401, FTS 626-8401.

It is availabic to the public from the

National Technical Information Service,

U.S. Department of Commerce,

5285 Port Royal Road,

Springfield, VA 22161. 

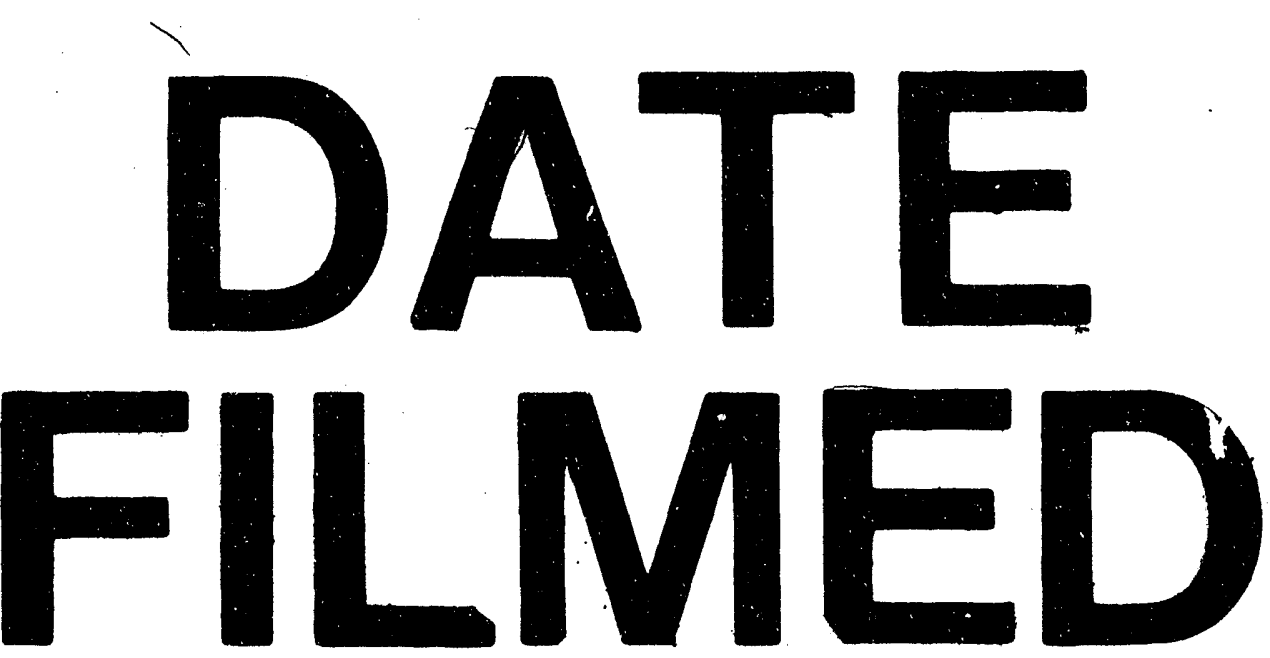

1

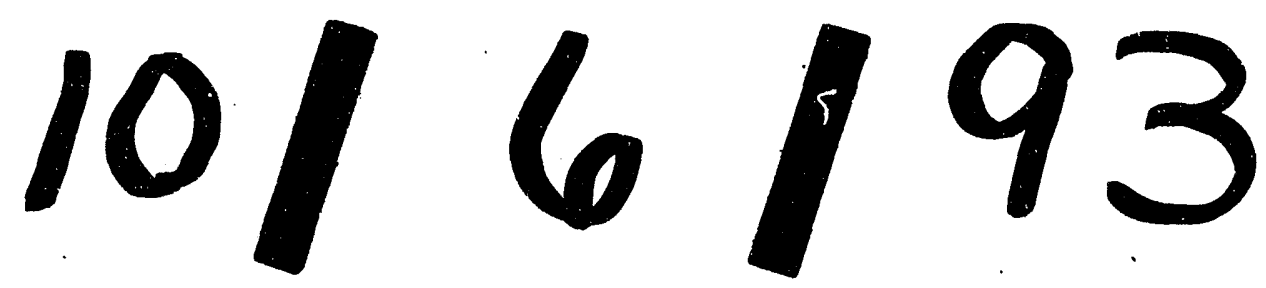


